\title{
Advanced Test Reactor Complex Facilities Radioactive Waste Management Basis and DOE Manual 435.1-1 Compliance Tables
}

November 2011

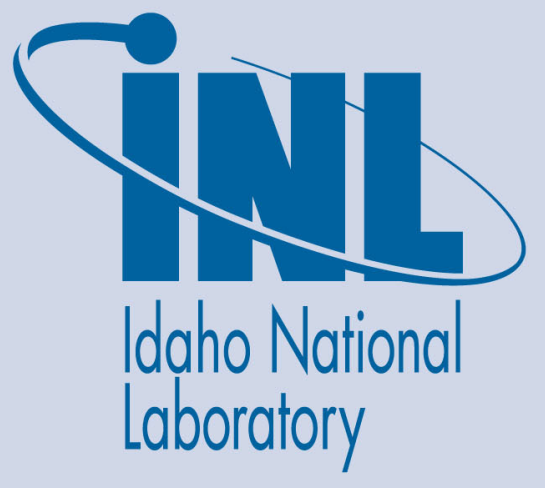

The INL is a U.S. Department of Energy National Laboratory operated by Battelle Energy Alliance 


\section{DISCLAIMER}

This information was prepared as an account of work sponsored by an agency of the U.S. Government. Neither the U.S. Government nor any agency thereof, nor any of their employees, makes any warranty, expressed or implied, or assumes any legal liability or responsibility for the accuracy, completeness, or usefulness, of any information, apparatus, product, or process disclosed, or represents that its use would not infringe privately owned rights. References herein to any specific commercial product, process, or service by trade name, trade mark, manufacturer, or otherwise, does not necessarily constitute or imply its endorsement, recommendation, or favoring by the U.S. Government or any agency thereof. The views and opinions of authors expressed herein do not necessarily state or reflect those of the U.S. Government or any agency thereof. 
INL/EXT-10-19789

Revision 3

\section{Advanced Test Reactor Complex Facilities Radioactive Waste Management Basis and DOE Manual 435.1-1 Compliance Tables}

November 2011

Idaho National Laboratory Idaho Falls, Idaho 83415

http://www.inl.gov

Prepared for the

U.S. Department of Energy

Office of Nuclear Energy

Under DOE Idaho Operations Office

Contract DE-AC07-05ID14517 



\begin{abstract}
U.S. Department of Energy Order 435.1, "Radioactive Waste Management," along with its associated manual and guidance, requires development and maintenance of a radioactive waste management basis for each radioactive waste management facility, operation, and activity. This document presents a radioactive waste management basis for Idaho National Laboratory's Advanced Test Reactor Complex facilities that manage radioactive waste. The radioactive waste management basis for a facility comprises existing laboratory-wide and facility-specific documents. U.S. Department of Energy Manual 435.1-1, "Radioactive Waste Management Manual," facility compliance tables also are presented for the facilities. The tables serve as a tool to develop the radioactive waste management basis.
\end{abstract}




\section{CONTENTS}

ABSTRACT iii

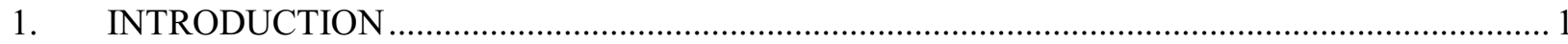

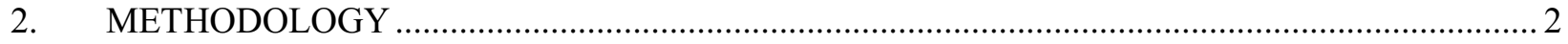

3. SCOPE

4. FACILITY RADIOACTIVE WASTE MANAGEMENT BASIS AND DOE

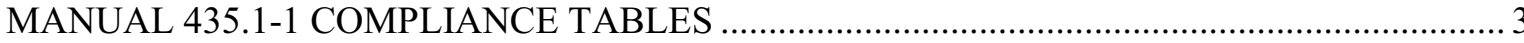

4.1 TRA-605 Radioactive Materials Storage Area .............................................................. 4

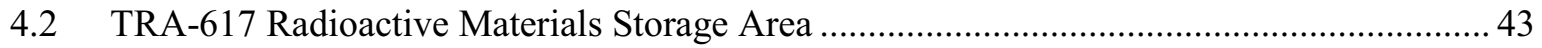

4.3 TRA-621, Nuclear Materials Inspection and Storage Facility …........................................6 66

$4.4 \quad$ TRA-666, Safety and Tritium Applied Research Facility ................................................. 90

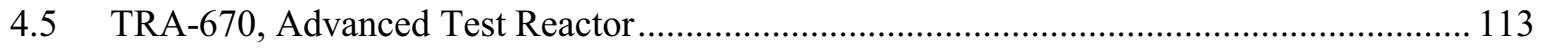

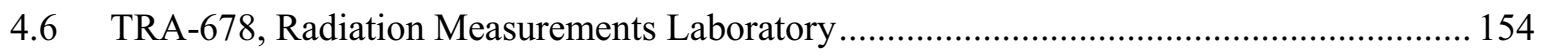

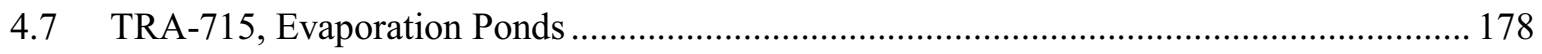

4.8 TRA-780 (includes TRA-681, 682, 683, and 684), Resource Conservation and Recovery Act 90-Day Storage Area................................................................................ 203

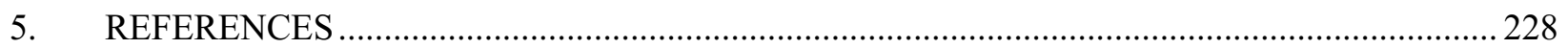

\section{TABLES}

1. TRA-605 Radioactive Materials Storage Area DOE Manual 435.1-1 transuranic waste requirements and facility compliance information 5

2. TRA-605 Radioactive Materials Storage Area DOE Manual 435.1-1 low-level waste requirements and facility compliance information

3. TRA-617 Radioactive Materials Storage Area DOE Manual 435.1-1 low-level waste requirements and facility compliance information

4. TRA-621, Nuclear Materials Inspection and Storage Facility, DOE Manual 435.1-1 low-level waste requirements and facility compliance information

5. TRA-666, Safety and Tritium Applied Research Facility, DOE Manual 435.1-1 lowlevel waste requirements and facility compliance information 
6. TRA-670, Advanced Test Reactor, and TRA-1005, Advanced Test Reactor Storage Pad, DOE Manual 435.1-1 transuranic waste requirements and facility compliance information

7. TRA-670, Advanced Test Reactor, DOE Manual 435.1-1 low-level waste requirements and facility compliance information

8. TRA-678, Radiation Measurements Laboratory, DOE Manual 435.1-1 low-level waste requirements and facility compliance information.

9. TRA-715, Evaporation Ponds, DOE Manual 435.1-1 low-level waste requirements and facility compliance information.

10. TRA-780, Resource Conservation and Recovery Act 90-Day Storage Area, DOE Manual 435.1-1 low-level waste requirements and facility compliance information. 


\section{Advanced Test Reactor Complex Facilities Radioactive Waste Management Basis and DOE Manual 435.1-1 Compliance Tables}

\section{INTRODUCTION}

The U.S. Department of Energy (DOE) ensures that DOE radioactive waste is managed in a manner that is protective of worker and public health and the environment through DOE Order 435.1, "Radioactive Waste Management," and its associated manual (DOE Manual 435.1-1, "Radioactive Waste Management Manual") and guidance (DOE Guide 435.1-1, "Implementation Guide for Use with DOE M 435.1-1"). As required by DOE Manual 435.1-1, I.F.(2), field element managers are responsible for ensuring that a radioactive waste management basis (RWMB) is developed and maintained for each DOE radioactive waste management facility, operation, and activity. The RWMB must do the following:

- Reference or define the conditions under which the facility may operate based on the radioactive waste management documentation

- Include the applicable elements indentified in the specific waste type chapters of the manual (DOE Manual 435.1-1)

- Be developed using the graded approach process.

The specific waste type chapters of DOE Manual 435.1-1 are high-level waste (Chapter II), transuranic (TRU) waste (Chapter III), and low-level waste (LLW) (Chapter IV). The RWMB is required to consist of "physical and administrative controls to ensure the protection of workers, the public, and the environment." For TRU waste and LLW, the RWMB is to include the following specific waste management controls:

- For generators, the waste certification program

- For treatment facilities and storage facilities, the waste acceptance requirements and the waste certification program

- For disposal facilities, the performance assessment, composite analysis, disposal authorization statement, closure plan, waste acceptance requirements, and monitoring plan.

Similar waste management controls are specified for high-level waste generators and high-level waste pretreatment, treatment, and storage facilities.

However, consistent with the graded approach provided in the DOE guidance, the required elements of the RWMB vary with the type of waste management operation or facility and the types of hazards associated with the facility. Therefore, the elements that are included in the guidance for each waste type chapter of the manual are not to be considered a complete list of elements. For example, the elements determined to be applicable to the RWMB for a facility may include the facility safety basis; authorization basis; operational procedures; radiation protection controls and procedures; waste characterization and certification plan; waste acceptance criteria; waste tracking and records management; waste storage and staging requirements; facility monitoring; quality assurance; and regulatory permits and appropriate documentation for permitted facilities.

The purpose of this document is to present a RWMB for Advanced Test Reactor (ATR) Complex facilities that manage radioactive waste and DOE Manual 435.1-1 facility compliance information tables for the ATR Complex facilities. The facility RWMB comprises existing laboratory-wide and facilityspecific documents. The DOE Manual 435.1-1 facility compliance information tables show how each facility meets the DOE Manual 435.1-1 requirement for a waste type and serve as a tool to develop the RWMB. The tables provide information that BEA and facility management officials can use to apply the 
graded approach emphasized in DOE Order 435.1 and its associated manual and guidance. This document is intended to support the summary RWMB (PLN-3638) for the facilities managing radioactive waste at the ATR Complex. The summary RWMB is to be submitted to the DOE field element manager for approval.

\section{METHODOLOGY}

The following methodology was used to prepare RWMB and facility compliance information tables for the ATR Complex:

- A kick-off meeting was held with ATR Complex officials. At this meeting, a preliminary list of ATR Complex facilities that should be included in this effort was verified. Based on the information obtained at this meeting, the list of facilities was modified slightly. The ATR Complex officials also provided the point of contact (POC) for each facility that could provide facility radioactive waste management information.

- Interviews were conducted with the primary POCs to discuss radioactive waste management procedures and programs at each facility. The interviews were conducted April 12 and April 13, 2010.

- Based on the information received from the interviews; analysis of the procedures cited by the facility POCs; and information found through the Electronic Document Management System, initial draft tables describing facility-level compliance with DOE Manual 435.1-1 requirements for each facility and each waste type managed at the facility were developed.

- A series of review meetings were conducted with the facility POCs and BEA management officials. These review meetings served as verification of the information presented in the initial draft tables, which were based on information obtained from the POC interviews and analysis of documents from the Electronic Document Management System. The meetings also allowed BEA management officials to discuss and make decisions regarding the potential compliance issues identified in the tables. The BEA management officials determined areas where BEA would take further actions and also areas where further actions were not necessary (e.g., issues where the BEA management officials decided that sufficient compliance was provided by Idaho National Laboratory [INL]-wide procedures or programs). The review meetings were held between May 14 and May 18, 2010.

- The tables were revised based on input received during the review meetings.

- For each facility, a preliminary RWMB and a list of areas requiring further BEA and facility management actions were developed based on information from the revised tables.

In developing and reviewing the compliance information and preliminary RWMB, the graded approach that DOE specifies for developing the RWMB and that is emphasized throughout the DOE Guide 435.1-1 guidance was used. The guidance also states that, when possible, existing processes, programs, and documentation should be considered as possible ways to comply with DOE Manual 435.1-1 requirements (DOE Guide 435.1-1).

Both the manual and associated guidance were considered in developing and reviewing the preliminary RWMB. DOE Manual 435.1-1 describes the requirements and establishes specific responsibilities for implementing DOE Order 435.1 for management of DOE high-level waste, TRU waste, LLW, and the radioactive component of mixed waste. DOE Guide 435.1-1 was developed to aid in implementing DOE Manual 435.1-1 requirements. The guide aids in understanding what is necessary to attain compliance, facilitates effective and efficient implementation of the requirements, and offers acceptable ways to implement the requirements. The guide is not meant to be viewed as additional or mandatory requirements. The guide emphasizes consideration of situation-specific attributes and application of the graded approach to dictate the rigor applied to implementation (DOE Guide 435.1-1 and DOE Manual 435.1-1). 


\section{SCOPE}

The following ATR Complex facilities were identified as managing radioactive waste and are included in this study:

- TRA-605, Effluent Processing Facility

- TRA-605 Radioactive Materials Storage Area

- TRA-617 Radioactive Materials Storage Area

- TRA-621, Nuclear Materials Inspection and Storage (NMIS) Facility

- $\quad$ TRA-666, Safety and Tritium Applied Research (STAR) Facility

- $\quad$ TRA-670, ATR, includes the TRA-605, Effluent Processing Facility; TRA-1005, ATR Storage Pad; and TRA-1006, Storage Area Southwest of TRA-670

- $\quad$ TRA-678, Radiation Measurement Laboratory

- TRA-715, Evaporation Ponds

- TRA-780, (includes TRA-681, 682, 683, 684, 685, and 686) Resource Conservation and Recovery Act (RCRA) 90-Day Storage Area.

The following ATR Complex facilities were identified as new facilities that are expected to manage radioactive waste after the facility begins operations:

- $\quad$ TRA-1627, Radioanalytical Chemistry Laboratory

- $\quad$ TRA-1710, Radioactive Materials Storage Area.

Based on the information obtained from the primary POCs regarding these facilities and a search for documentation through the Electronic Document Management System, no facility documentation pertaining to intended facility operations was identified that would enable an assessment of whether the facility has procedures or programs in place to comply with DOE Manual 435.1-1 requirements. Therefore, compliance tables were not developed for these facilities.

Prior to the kick-off meeting, the following facilities were identified as facilities that manage radioactive waste. However, information obtained during the kick-off meeting that was held with facility representatives or during subsequent POC interviews confirmed that radioactive waste management activities are not conducted at these facilities. Therefore, compliance information tables were not developed for these facilities:

- TRA-604, Basement

- TRA-1624, (building name not identified).

\section{FACILITY RADIOACTIVE WASTE MANAGEMENT BASIS AND DOE MANUAL 435.1-1 COMPLIANCE TABLES}

This section presents the RWMB and DOE Manual 435.1-1 compliance tables for the following ATR Complex facilities:

- TRA-605 Radioactive Materials Storage Area (Subsection 4.1)

- TRA-617 Radioactive Materials Storage Area (Subsection 4.2)

- TRA-621, NMIS Facility (Subsection 4.3)

- $\quad$ TRA-666, STAR Facility (Subsection 4.4) 
- $\quad$ TRA-670, ATR, including TRA-605, Effluent Processing Facility; TRA-1005, ATR Storage Pad; and TRA-1006, Storage Area Southwest of TRA-670 (Subsection 4.5)

- $\quad$ TRA-678, Radiation Measurement Laboratory (Subsection 4.6)

- $\quad$ TRA-715, Evaporation Ponds (Subsection 4.7)

- $\quad$ TRA-780, (includes TRA-681, 682, 683, and 684) RCRA 90-Day Storage Area (Subsection 4.8).

For each ATR Complex facility, a brief facility overview is provided. The overview includes a facility description, the facility's safety basis classification, the radioactive waste management activities and waste types for the facility, a list of the RWMB documents and programs for the facility, and a list of the compliance requirements needing further BEA management action.

The DOE Manual 435.1-1 compliance information table for each radioactive waste type managed at each ATR Complex facility also is provided for each facility. Each table shows the DOE Manual 435.1-1 requirement, facility compliance information for each requirement, and compliance issues for consideration by INL, BEA, and facility management, as appropriate. In some cases, excerpts from the DOE Guide 435.1-1 guidance associated with the DOE Manual 435.1-1 requirement are included. These excerpts are included to provide additional context and information about the requirement. However, the complete guidance citation should be consulted for decision-making.

\subsection{TRA-605 Radioactive Materials Storage Area}

1. Facility description: The TRA-605 Radioactive Materials Storage Area is a fenced outside storage area located $40 \mathrm{ft}$ east of TRA-605. The area is approximately $27 \times 31 \mathrm{~m}(74 \times 86 \mathrm{ft})$ with a non-gated entrance in the southwest corner. Waste Generator Services (WGS) is the Radioactive Materials Storage Area custodian for this facility. Although this facility is identified with the same building number as the TRA-605, Effluent Processing Facility, also known as the Warm Waste Treatment Facility (WWTF), for the purposes of the RWMB, they are considered two separate and distinct waste management facilities. TRA-605, Effluent Processing Facility, is included in Section 5.4, TRA-670, ATR, to maintain consistency with the facility's safety basis documentation.

2. Hazard category: Less-than-Hazard-Category-3 (LTHC3) (radiological)

3. Radioactive waste managed at this facility: Remote-handled legacy LLW (solid) and remote-handled legacy TRU waste (solid) are stored at this facility. Routine contact-handled LLW and Toxic Substances Control Act (TSCA)-regulated LLW also may be accepted at this facility.

\section{RWMB documents/programs:}

a) Safety basis/hazard analysis:

- HAD-277, "Reactor Technology Complex Radioactive Materials Storage Areas (TRA-617 and the Fenced Area East of TRA-605)"

- SD-24.1.3, "ATR Complex Facilities and Site Services Safety Basis Administrative Controls"

b) Laboratory-wide:

- Form 435.A01, "Radioactive Waste Container Inspection Checklist"

- Form 435.39, "Waste Determination and Disposition Form (WDDF)"

- Form 435.42, "Radioactive Waste Inventory Sheet"

- Form 441.A34, "INL Radiological Control Required Surveys"

- LI-435, "Waste Management Routine Field Activities"

- LRD-15001, "Radiological Control Manual"

- LWP-13840, "Management of Issues, Observations, and Noteworthy Practices" 
- LWP-14002, "Timeout and Stop Work Authority"

- LWP-15011, "Radioactive Material Areas and Radioactive Storage Areas"

- MCP-139, "Radiological Surveys"

- MCP-17000, "Waste Generator Services Waste Management"

- MCP-17410, "Management of Waste Storage Areas"

- MCP-17500, "Waste Generator Services Certification of Waste Shipments to the Nevada Test Site"

- PDD-17000, "Waste Management Program"

- PLN-114, "INL Emergency Plan/RCRA Contingency Plan"

- PLN-522, "Quality Assurance Program Plan for the Waste Management/Waste Certification Program."

c) Facility-specific:

- IAG-443, “Tenant Use Agreement Between Facility Management Services, Laboratory Support Complex at the Advanced Test Reactor Complex and Waste Generator Services/Energy Solutions in Materials Storage Areas TRA-617 And Fenced Area East of TRA-605"

- For legacy remote-handled TRU waste: the TRU waste at this facility is legacy remote-handled TRU waste that is being proposed for transfer to the DOE Office of Environmental Management (EM) contractor for their management and disposition. Acceptable knowledge and characterization information will be provided to demonstrate compliance with the DOE-EM waste acceptance criteria for the receiving organization. The program is described in Excess Legacy Materials Inventory Report for the Idaho National Laboratory (INL 2010).

TRU waste and LLW are managed at this facility. Table 1 shows the facility compliance information for DOE Manual 435.1-1 Chapter III, "Transuranic Waste Requirements," and Table 2 presents the facility compliance information for Chapter IV, "Low-level Waste Requirements."

Table 1. TRA-605 Radioactive Materials Storage Area DOE Manual 435.1-1 transuranic waste requirements and facility compliance information.

\begin{tabular}{|l|l|}
\hline \multicolumn{2}{|c|}{ TRA-605 Radioactive Materials Storage Area } \\
\hline \multicolumn{1}{|c|}{ Chapter III, Transuranic Waste Requirements } & \multicolumn{1}{|c|}{ Facility Compliance Information } \\
\hline $\begin{array}{l}\text { A. Definition of Transuranic Waste. Transuranic waste } \\
\text { is radioactive waste containing more than 100 } \\
\text { nanocuries (3700 becquerels) of alpha-emitting } \\
\text { transuranic isotopes per gram of waste, with half-lives } \\
\text { greater than 20 years, except for: } \\
\begin{array}{l}\text { (From DOE G 435.1-1 Chapter III: The determination of } \\
\text { transuranic waste should be made at the time of waste } \\
\text { certification, that is, each time the waste is transferred to } \\
\text { another person or facility.) }\end{array}\end{array}$ & $\begin{array}{l}\text { This requirement proves the criteria for determining } \\
\text { which DOE radioactive waste is to be managed as TRU } \\
\text { waste in accordance with DOE Manual 435.1-1, } \\
\text { Chapter III. } \\
\text { See J. below. }\end{array}$ \\
\hline \begin{tabular}{l} 
(1) High-level radioactive waste; \\
\hline $\begin{array}{l}\text { (2) Waste that the Secretary of Energy has determined, } \\
\text { with the concurrence of the Administrator of the } \\
\text { Environmental Protection Agency, does not need the } \\
\text { degree of isolation required by the 40 CFR Part 191 } \\
\text { disposal regulations; or }\end{array}$
\end{tabular} & See A. above. \\
\hline
\end{tabular}


Table 1. (continued).

TRA-605 Radioactive Materials Storage Area

Chapter III, Transuranic Waste Requirements

(3) Waste that the Nuclear Regulatory Commission has approved for disposal on a case-by-case basis in accordance with 10 CFR Part 61.

B. Management of Specific Wastes. The following provide for management of specific wastes as transuranic waste in accordance with the requirements in this Chapter:

From DOE G 435.1-1 Chapter III: Compliance with these requirements is demonstrated if RCRA, statehazardous, and TSCA-regulated radioactive wastes are being managed in compliance with applicable requirements and agreements or in accordance with a consent order, and consistent with the Transuranic Waste Requirements of DOE M 435.1-1.

(1) Mixed Transuranic Waste. Transuranic waste determined to contain both a hazardous component subject to the Resource Conservation and Recovery Act (RCRA), as amended, and a radioactive component subject to the Atomic Energy Act of 1954, as amended, shall be managed in accordance with the requirements of RCRA and DOE O 435.1, Radioactive Waste Management, and this Manual.

(2) TSCA-Regulated Waste. Transuranic waste containing polychlorinated biphenyls, asbestos, or other such regulated toxic components shall be managed in accordance with requirements derived from the Toxic Substances Control Act, as amended, DOE O 435.1, Radioactive Waste Management, and this Manual.

(3) Pre-1970 Transuranic Waste. Transuranic waste disposed of prior to implementation of the 1970 Atomic Energy Commission Immediate Action Directive regarding retrievable storage of transuranic waste is not subject to the requirements of DOE O 435.1, Radioactive Waste Management, and this Manual.

C. Complex-Wide Transuranic Waste Management Program. A complex-wide program and plan shall be developed as described under Responsibilities, 2.B and 2.D, in Chapter I of this Manual.

From DOE G 435.1-1 Chapter III: Compliance with this requirement is demonstrated by the presence of a Complex-Wide Transuranic Waste Management Program which includes the appropriate interfaces, technical information, data inputs, and other elements described in Chapter I of this Manual.
Not applicable (NA); mixed TRU waste is not managed at this facility.

NA; TSCA-regulated TRU waste is not managed at this facility.

NA; Pre-1970 TRU waste is not managed at this facility.

Not a facility-specific requirement. DOE Manual 435.1-1 $\S$ I.2.B and §I.2.D apply to the Assistant Secretary for Environmental Management and the Deputy Assistant Secretary for Waste Management, respectively. 
Table 1. (continued).

TRA-605 Radioactive Materials Storage Area

Chapter III, Transuranic Waste Requirements

D. Radioactive waste management basis. Transuranic waste facilities, operations, and activities shall have a radioactive waste management basis consisting of physical and administrative controls to ensure the protection of workers, the public, and the environment. The following specific waste management controls shall be part of the radioactive waste management basis:

From DOE G 435.1-1 Chapter III: Compliance with this requirement is demonstrated if, the radioactive waste management basis is documented and signed by the Field Element manager or a designee (see DOE M 435.1-1, Section I.1.A, Delegation of Authority) for each transuranic waste management facility, operation, or activity. Using a graded approach, it may be possible to include multiple activities under a single radioactive waste management basis, but it should be possible to objectively identify which activities are covered. Further, the radioactive waste management basis includes or references the controls that are established on a facility-specific basis to address the unique waste management requirements and circumstances for each facility, operation, and/or activity.

(1) Generators. The waste certification program.

From DOE G 435.1-1 Chapter III: For a facility that generates transuranic waste, the radioactive waste management basis is to include the program for certifying that waste meets the waste acceptance requirements of the facility(ies) to which the waste will be sent.

(2) Treatment Facilities. certification program. The waste acceptance requirements and the waste [sic]

From DOE G 435.1-1 Chapter III: Facilities that store or treat transuranic waste are to have approved waste acceptance requirements (see DOE M 435.1-1, Section III.G) prior to the issuance of a radioactive waste management basis. The waste acceptance requirements will usually suffice as documentation of the radiological, physical, and chemical limitations on waste that can be safely received at the facility, provided they are developed correctly with consideration of the hazards of the waste to be managed, and are kept up to date. Controls on the radiological, physical and chemical limitations need to include considerations of the potential effects of radiolysis.

A facility that stores or treats waste is generally expected to have a waste certification program. Waste from these facilities will have to be certified as meeting the waste acceptance requirements of the facility to

\section{Facility Compliance Information}

The RWMB provides the regulatory framework for management of radioactive waste at INL. It specifically identifies facility management and implementing documents for the generation, storage, treatment, and disposal of radiological waste.

TRU waste management is addressed in PDD-17000. Routine waste management activities are conducted in accordance with LI-435.

This facility is a LTHC3 facility (HAD-277).

SD-24.1.3 identifies administrative controls, method of compliance, and responsible organization so that the hazard classification is maintained.

NA; TRU waste is not generated at this facility. 
Table 1. (continued).

\section{TRA-605 Radioactive Materials Storage Area}

Chapter III, Transuranic Waste Requirements

which it will be transferred and the facilities have the potential for generating radioactive waste (e.g., secondary processing streams from treatment, monitoring and sampling, radioactive release cleanup). Consequently, storage and treatment facilities should also have an approved waste certification program as part of their radioactive waste management basis.

As part of the radioactive waste management basis, site personnel should implement a system or process for tracking the waste inventory at a storage, treatment, or disposal facility.

(3) Storage Facilities. The waste acceptance requirements and the waste certification program.

See G. and J. below for waste acceptance and waste certification program requirements.

From DOE G 435.1-1 Chapter III: Facilities that store or treat transuranic waste are to have approved waste acceptance requirements (see DOE M 435.1-1, Section III.G) prior to the issuance of a radioactive waste management basis. The waste acceptance requirements will usually suffice as documentation of the radiological, physical, and chemical limitations on waste that can be safely received at the facility, provided they are developed correctly with consideration of the hazards of the waste to be managed, and are kept up to date. Controls on the radiological, physical and chemical limitations need to include considerations of the potential effects of radiolysis.

A facility that stores or treats waste is generally expected to have a waste certification program. Waste from these facilities will have to be certified as meeting the waste acceptance requirements of the facility to which it will be transferred and the facilities have the potential for generating radioactive waste (e.g., secondary processing streams from treatment, monitoring and sampling, radioactive release cleanup). Consequently, storage and treatment facilities should also have an approved waste certification program as part of their radioactive waste management basis.

As part of the radioactive waste management basis, site personnel should implement a system or process for tracking the waste inventory at a storage, treatment, or disposal facility.

(4) Disposal Facilities. The performance assessment, disposal authorization statement, waste acceptance requirements, and monitoring plan.

-277 establishes the facility as a LTHC3 facility and requires the facility manager to implement a method of tracking and controlling the radioactive material inventory so that the sum-of-the-ratios does not exceed 1.

SD-24.1.3, Appendix B addresses the use of Integrated Waste Tracking System (IWTS) to track the radionuclide quantity limits and the establishment of an alarm/warning limit in IWTS.

NA; this facility is not a disposal facility.

NA, this facility is not a disposal facility. 
Table 1. (continued).

\begin{tabular}{|c|c|}
\hline \multicolumn{2}{|c|}{ TRA-605 Radioactive Materials Storage Area } \\
\hline Chapter III, Transuranic Waste Requirements & Facility Compliance Information \\
\hline $\begin{array}{l}\text { E. Contingency Actions. The following requirements are } \\
\text { in addition to those in Chapter I of this Manual. } \\
\text { From DOE G } 435.1-1 \text { Chapter III: Compliance with } \\
\text { these requirements is demonstrated by having adequate } \\
\text { spare capacity and transfer equipment exists for } \\
\text { emergency transfers of all liquid transuranic waste. In } \\
\text { addition, the capability to perform emergency transfers } \\
\text { is demonstrated by having waste transfer routings } \\
\text { identified, operational procedures to direct transfers, } \\
\text { staff trained to the procedures, and records showing that } \\
\text { the spare capacity and transfer capability are kept in } \\
\text { operating condition. }\end{array}$ & $\begin{array}{l}\text { Not a facility-specific requirement. DOE Manual 435.1-1 } \\
\text { §I.1.E(5) addresses the sitewide emergency management } \\
\text { system. The INL plan is provided in PLN-114. }\end{array}$ \\
\hline $\begin{array}{l}\text { (1) Contingency Storage. For off-normal or emergency } \\
\text { situations involving liquid transuranic waste storage or } \\
\text { treatment, spare capacity with adequate capabilities shall } \\
\text { be maintained to receive the largest volume of liquid } \\
\text { contained in any one storage tank or treatment facility. } \\
\text { Tanks or other facilities that are designated transuranic } \\
\text { waste contingency storage shall be maintained in an } \\
\text { operational condition when waste is present and shall } \\
\text { meet the requirements of DOE O } 435.1, \text { Radioactive } \\
\text { Waste Management, and this Manual. }\end{array}$ & $\begin{array}{l}\text { NA; this facility does not store or treat liquid TRU waste } \\
\text { in tanks. }\end{array}$ \\
\hline $\begin{array}{l}\text { (2) Transfer Equipment. Pipelines and auxiliary } \\
\text { facilities necessary for the transfer of liquid waste to } \\
\text { contingency storage shall be maintained in an } \\
\text { operational condition when waste is present and shall } \\
\text { meet the requirements of DOE O } 435.1 \text {, Radioactive } \\
\text { Waste Management, and this Manual. }\end{array}$ & $\begin{array}{l}\text { NA; this facility does not store or treat liquid TRU waste } \\
\text { in tanks. }\end{array}$ \\
\hline $\begin{array}{l}\text { F. Corrective Actions. I of this Manual. The following } \\
\text { requirements are in addition to those in Chapter [sic] }\end{array}$ & $\begin{array}{l}\text { The INL-wide procedure addressing problem } \\
\text { identification as required by DOE Manual } 435.1-1 \\
\text { §I.2.G.(1) is LWP-13840, which implements the } \\
\text { laboratory's corrective action system. } \\
\text { The INL-wide procedure addressing shutdown or } \\
\text { curtailment of activities as required by DOE } \\
\text { Manual 435.1-1 §I.2.G.(2) is LWP-14002. }\end{array}$ \\
\hline $\begin{array}{l}\text { (1) Order Compliance. Corrective actions shall be } \\
\text { implemented whenever necessary to ensure the } \\
\text { requirements of DOE O } 435.1 \text {, Radioactive Waste } \\
\text { Management, and this Manual are met. } \\
\text { From DOE G } 435.1-1 \text { Chapter III: If a facility or activity } \\
\text { can be allowed to operate while a noncompliant or } \\
\text { hazardous condition exists, the allowance and any } \\
\text { associated limitations must be defined as part of the } \\
\text { facility's or activity's radioactive waste management } \\
\text { basis, identified as a configuration controlled item in a } \\
\text { configuration management plan or included in a revision } \\
\text { or modification to an operating procedure or similar }\end{array}$ & See F. above. \\
\hline
\end{tabular}


Table 1. (continued).

TRA-605 Radioactive Materials Storage Area

\begin{tabular}{l} 
Chapter III, Transuranic Waste Requirements \\
\hline controlled documentation. \\
Compliance with this requirement is demonstrated if a \\
corrective action system exists which addresses \\
noncompliant or hazardous situations associated with \\
transuranic waste management and in a systematic \\
fashion, and allows identification of problems by all \\
personnel.
\end{tabular}

(2) Operations Curtailment. Operations shall be curtailed or facilities shut down for failure to establish, maintain, or operate consistent with an approved radioactive waste management basis.

From DOE G 435.1-1 Chapter III: Compliance with this requirement is demonstrated by documented evidence of systematic, routine reviews to determine whether waste management activities and facilities under are operating in accordance with an approved radioactive waste management basis. In addition, the documentation should show that limitations (which may include shutdown) have been placed on activities and operations that do not have or are operating outside the conditions of an approved radioactive waste management basis.

G. Waste Acceptance. The following requirements are in addition to those in Chapter I of this Manual.

(1) Technical and Administrative. Waste acceptance requirements for all transuranic waste storage, treatment, or disposal facilities, operations, and activities shall specify, at a minimum, the following:

From DOE G 435.1-1 Chapter III: Compliance with these requirements is demonstrated if waste acceptance requirements are documented, contain clear and precise criteria specifying the radionuclide limits in the form of contents or concentrations that can be accepted, the limitations and prohibitions on waste forms and packages that can be received, and the limits, prohibitions, or instructions concerning any other technical information so that the waste is compatible with the safety basis of the facility, and which will result in acceptable waste at subsequent steps in managing the transuranic waste. Waste acceptance requirements are to also contain a clear description of the process and bases for obtaining an exception or deviation to the acceptance criteria for transuranic waste to be received at the facility.

(a) Allowable activities and/or concentrations of specific See (1) above. radionuclides;
The approved RWMB establishes the current compliance status at each radioactive waste management facility. Facility assessments are scheduled to ensure waste management activities are conducted in accordance with the approved RWMB.

Not a facility-specific requirement. DOE Manual 435.1-1 $\S \mathrm{I} .2 . \mathrm{F}(6)$ applies to field element managers.

HAD-277 establishes the facility as a LTHC3 facility and requires the facility manager to implement a method of tracking and controlling the radioactive material inventory so that the sum-of-the-ratios does not exceed 1 .

SD-24.1.3, Appendix B provides the procedure for ensuring that stored waste limits are not exceeded and delegates this responsibility to the Radioactive Material Storage Area custodian.

IAG-443 establishes WGS as the Radioactive Material Storage Area custodian. Appendix A, Article II outlines requirements for controlling radiological material inventories.

The TRU waste at this facility is legacy remote-handled TRU waste that is being proposed for transfer to the EM contractor for their management and disposition. Additional TRU waste is not planned to be received at this facility. Facility Compliance Information 
Table 1. (continued).

TRA-605 Radioactive Materials Storage Area

Chapter III, Transuranic Waste Requirements

(b) Acceptable waste form and/or container requirements that ensure the chemical and physical stability of waste under conditions that might be encountered during transportation, storage, treatment, or disposal;

(c) Restrictions or prohibitions on waste, materials, or containers that may adversely affect waste handlers or compromise facility or waste container performance;

(d) Requirement to identify transuranic waste as defense See (1) above. or non-defense, and limitations on acceptance; and

(e) The basis, procedures, and levels of authority required for granting exceptions to the waste acceptance requirements, which shall be contained in each facility's waste acceptance documentation. Each exception request shall be documented, including its disposition as approved or not approved.

(2) Evaluation and Acceptance. The receiving facility shall evaluate waste for acceptance, including confirmation that technical and administrative requirements have been met. A process for the disposition of non-conforming wastes shall be established.

From DOE G 435.1-1 Chapter III: Compliance with these requirements is demonstrated if there is a procedure or process for evaluating and accepting incoming waste which ensures the acceptance criteria of the facility receiving the waste are met by one or a combination of: (1) testing, sampling, and analysis of representative samples of incoming waste upon receipt; (2) testing, sampling, and analysis of samples of waste taken at the generator facility; (3) evaluation of testing, sampling, and analysis of data provided by the generator; or (4) audits, reviews, or surveillances of generator waste certification programs and characterization activities. Additionally, acceptable waste acceptance requirements for a storage, treatment, or disposal facility will have documented procedures and actions to be taken if a waste that does not conform to the waste acceptance criteria is received at the facility.

H. Waste Generation Planning. The following requirements are in addition to those in Chapter I of this Manual.

(1) Life-Cycle Planning. Prior to waste generation, planning shall be performed to address the entire life cycle for all transuranic waste streams.

From DOE G 435.1-1 Chapter III: Compliance with this

See (1) above.

Exceptions to the radioactive material inventory limits are not permitted. Facility Compliance Information See (1) above. as

SD-24.1.3, Appendix B addresses the use of IWTS to track the radionuclide quantity limits and the establishment of an alarm/warning limit in IWTS.

Nonconforming waste is not permitted.
Not a facility-specific requirement. DOE Manual 435.1-1 §I.2.F(7) applies to field element managers.

NA; TRU waste is not generated at this facility. 
Table 1. (continued).

TRA-605 Radioactive Materials Storage Area

Chapter III, Transuranic Waste Requirements

planning requirement is demonstrated by the individual sites establishing a process for evaluating the life-cycle of [transuranic] waste prior to its generation, including the identification of [transuranic] wastes with no path to disposal and appropriate records justifying the newly generated [transuranic] waste stream(s), and site personnel possessing planning information showing the location(s) where [transuranic] waste will be stored, treated, and/or disposed along with a confirmation that the personnel managing the facilities agree that the [transuranic] waste may be managed at those facilities.

(2) Waste with No Identified Path to Disposal. Transuranic waste streams with no identified path to disposal shall be generated only in accordance with approved conditions which, at a minimum, shall address:

From DOE G 435.1-1 Chapter III: Compliance with requirement is demonstrated by the waste generation organization having documentation concerning the decision to generate a transuranic waste stream that does not have an identified path to disposal. This documentation needs to include the cognizant Field Element Manager or designee approval to generate the waste, an explanation of the need for the process that generates the transuranic waste, a discussion of the reason it cannot be disposed of, the proposed management plan for the waste, and an up-to-date schedule of activities being pursued to resolve constraints to the disposal of the subject waste. Consistent with the use of a graded approach for applying DOE M 435.1-1 requirements, the schedule and plans for disposing of nondefense waste can defer to the complex-wide resolution of the issue.

(a) Programmatic need to generate the waste;

NA; TRU waste is not generated at this facility. Facility Compliance Information

(b) Characteristics and issues preventing the disposal of See (2) above. the waste;

(c) Safe storage of the waste until disposal can be achieved; and

(d) Activities and plans for achieving final disposal of the waste.

I. Waste Characterization. Transuranic waste shall be characterized using direct or indirect methods, and the characterization documented in sufficient detail to ensure safe management and compliance with the waste acceptance requirements of the facility receiving the waste.

From DOE G 435.1-1 Chapter III: Compliance with this

See (2) above.

See (2) above.

IAG-443 establishes WGS as the Radioactive Material Storage Area custodian.

IAG-443, Appendix B, establishes WGS' functional responsibilities for waste, which are to arrange for the removal and disposition of waste generated and characterized by others.

The waste acceptance criteria will be established by the 
Table 1. (continued).

TRA-605 Radioactive Materials Storage Area

Chapter III, Transuranic Waste Requirements

requirement is demonstrated by a program for documenting and the existence of records that document the process for acquiring and verifying the validity of transuranic waste characterization data acquired through the use of direct or indirect methods.

(1) Data Quality Objectives. The data quality objectives process, or a comparable process, shall be used for identifying characterization parameters and acceptable uncertainty in characterization data.

From DOE G 435.1-1 Chapter III: Compliance with this requirement is demonstrated by the documented use of a data quality objectives or a comparable process for determining the type, quantity, and quality of characterization data needed to safely manage transuranic waste.

(2) Minimum Waste Characterization. Characterization data shall, at a minimum, include the following information relevant to the management of the waste:

From DOE G 435.1-1 Chapter III: Compliance with this requirement is demonstrated by the existence of a program or procedures for determining and records that document characterization of transuranic waste consistent with the minimum characterization data requirements.

(a) Physical and chemical characteristics;

(b) Volume, including the waste and any stabilization or absorbent media;

(c) Weight of the container and contents;

(d) Identities, activities, and concentrations of major radionuclides;

(e) Characterization date;

(f) Generating source;

(g) Packaging date; and

(h) Any other information which may be needed to prepare and maintain the disposal facility performance assessment or demonstrate compliance with applicable performance objectives.

J. Waste Certification. A waste certification program shall be developed, documented, and implemented to ensure that the waste acceptance requirements of facilities receiving transuranic waste for storage, treatment, or disposal are met.

From DOE G 435.1-1 Chapter III: Compliance with the development and documentation portion of the
Facility Compliance Information

DOE-EM contractor to which this waste is proposed to

be transferred. Acceptable knowledge and

characterization information will be provided to

demonstrate compliance with these criteria.

Radioactive waste management facilities characterize waste in accordance with the requirements of the receiving storage, treatment, or disposal facility. The documented use of a data quality objectives process, or comparable process, was not identified for this facility.

IAG-443 establishes WGS as the Radioactive Material Storage Area custodian.

IAG-443, Appendix B, establishes WGS' functional responsibilities for waste, which are to arrange for the removal and disposition of waste generated and characterized by others. MCP- $17000 \S 4$ specifies the requirements for preparing an IWTS profile that captures waste characterization information.

See (2) above.

See (2) above.

See (2) above.

See (2) above.

See (2) above.

See (2) above.

See (2) above.

See (2) above.

NA; no certification program for this waste. The TRU waste at this facility is legacy remote-handled TRU waste that is being proposed for transfer to the DOE-EM contractor for their management and disposition. Acceptable knowledge and characterization information will be provided to demonstrate compliance with the DOE-EM waste acceptance criteria for the receiving 
Table 1. (continued).

TRA-605 Radioactive Materials Storage Area

Chapter III, Transuranic Waste Requirements

certification requirement is demonstrated by a waste certification plan that identifies the organizations involved, assigns responsibilities for implementing the program, and describes or references the quality assurance, training, procurement controls, records management, and procedures to be used by the program. Acceptable performance for implementing the program is demonstrated when the appropriate personnel are trained, and have and follow the procedures that govern their part of the waste certification process. Acceptable performance also requires that the waste certification plan and procedures are current and controlled in accordance with a document control program, and records related to certification (e.g., certification statements, training records, procurement records, characterization records, container records) are generated and managed in accordance with the established site program.

(1) Certification Program. The waste certification program shall designate the officials who have the authority to certify and release waste for shipment; and specify what documentation is required for waste generation, characterization, shipment, and certification. The program shall provide requirements for auditability, retrievability, and storage of required documentation and specify the records retention period.

From DOE G 435.1-1 Chapter III: Compliance with this requirement is demonstrated by a program or procedure for record keeping and records showing that each container of waste is certified as having met the waste acceptance criteria of the facility to which it was transferred and the certification statement is supported by additional records regarding the waste source, characterization, and container.

(2) Certification before Transfer. Transuranic waste shall be certified as meeting waste acceptance requirements before it is transferred to the facility receiving the waste.

From DOE G 435.1-1 Chapter III: Compliance with this requirement is demonstrated by the presence of a certification program which includes procedures requiring a signed certification statement prior to the release of waste for transfer, and by dated records showing that waste was certified before being transferred.

(3) Maintaining Certification. Transuranic waste that has been certified as meeting the waste acceptance requirements for transfer to a storage, treatment, or disposal facility shall be managed in a manner that
Facility Compliance Information

organization to enable the transfer of ownership.

See J. above.

See J. above.
See J. above.

LWP-15011 $§ 5$ provides general radioactive storage area requirements and $\$ 5.1 .7$ addresses outdoor storage of 
Table 1. (continued).

TRA-605 Radioactive Materials Storage Area

Chapter III, Transuranic Waste Requirements

maintains its certification status.

From DOE G 435.1-1 Chapter III: Compliance with this requirement is demonstrated by the existence of a program or procedure reflecting this requirement and site personnel able to show that the storage of containers of waste is in a facility or manner where the containers are not damaged by normal weather events, and cannot be accessed by unauthorized personnel. Further, each container can be traced to its certification and the information supporting that certification.

K. Waste Transfer. A documented process shall be established and implemented for transferring responsibility for management of transuranic waste and for ensuring availability of relevant data. The following requirements are in addition to those in Chapter I of this Manual.

From DOE G 435.1-1 Chapter III: Compliance with this requirement is demonstrated if facilities have procedures for the receipt of waste and the transfer of waste, as appropriate, which address the acquisition of waste and container data and the transfer of ownership, respectively. Further evidence of acceptable performance is facility records showing that data on the waste containers are available and accurate, and that documented transfer of responsibility occurs.

(1) Authorization. Transuranic waste shall not be transferred to a storage, treatment, or disposal facility until personnel responsible for the facility receiving the waste authorize the transfer.

From DOE G 435.1-1 Chapter III: Compliance with this requirement is demonstrated by sites having procedures that require a confirmation of authorization before releasing waste for transfer, and records showing that transfers are made in accordance with written authorizations.

(2) Data. Waste characterization data, container information, and generation, storage, treatment, and transportation information for transuranic waste shall be transferred with or be traceable to the waste.

From DOE G 435.1-1 Chapter III: Compliance with this requirement is demonstrated if there are procedures requiring that characterization and container data be provided and maintained for each waste transfer and documented records of transfers show that the information is being provided.
Waste transfer for TRU waste at this facility is limited to the one-time transfer of the legacy remote-handled TRU waste managed at this facility. A waste-specific agreement will be developed to transfer management responsibility to the DOE-EM contractor for this waste.
See K. above.

See K. above. 
Table 1. (continued).

TRA-605 Radioactive Materials Storage Area

Chapter III, Transuranic Waste Requirements
$\begin{aligned} & \text { L. Packaging and Transportation. The following } \\ & \text { requirements are in addition to those in Chapter I of this } \\ & \text { Manual. }\end{aligned}$

(1) Packaging.

From DOE G 435.1-1 Chapter III: Compliance with the packaging requirement is demonstrated by procedures which document proper packaging protocols, including documented evidence that, where feasible, non-defense transuranic waste has been packaged separately from defense transuranic waste and by never having to repackage transuranic waste that is packaged after issuance of DOE O 435.1 in order to maintain containment. However, the above protocol may not be satisfied by containers that were placed in storage prior to issuance of the DOE O 435.1. For those containers, the goal is to only have to repackage the waste one time after it is retrieved and characterized. Further, acceptable performance is demonstrated by containers of waste having marking and labeling that allows correlation with waste characterization data and container information. Successful performance of this requirement is also demonstrated by a record of container performance in which failure has not routinely occurred.

(a) Transuranic waste shall be packaged in a manner that See (1) above. provides containment and protection for the duration of the anticipated storage period and until disposal is achieved or until the waste is removed from the container.

(b) Vents or other mechanisms to prevent pressurization See (1) above. of containers or generation of flammable or explosive concentrations of gases shall be installed on containers of newly-generated waste at the time the waste is packaged. Containers of currently stored waste shall meet this requirement as soon as practical unless analyses demonstrate that the waste can otherwise be managed safely.

From DOE G 435.1-1 Chapter III: In developing the radioactive waste management basis, site personnel need to consider the hazards associated with drums of transuranic waste which have not been provided with vents or been proven to not need vents through an approved safety analysis. For unvented containers in earthen-covered storage, the facility itself may mitigate the hazards associated with the accumulation of gases. For above-grade storage of transuranic waste containers, the radioactive waste management basis needs to include controls which mitigate the hazards associated
The TRU waste at this facility is legacy remote-handled TRU waste that is being proposed for transfer to the DOE-EM contractor for their management and disposition. Acceptable knowledge and characterization information will be provided to demonstrate compliance with the DOE-EM waste acceptance criteria for the receiving organization to enable transfer of ownership. These criteria would include requirements for packaging. The acceptable knowledge documentation is expected to indicate that the waste is defense waste. 
Table 1. (continued).

TRA-605 Radioactive Materials Storage Area

\begin{tabular}{l} 
Chapter III, Transuranic Waste Requirements \\
\hline $\begin{array}{l}\text { Tith the accumulation of gases by restricting access to } \\
\text { the storage area and providing equipment to protect } \\
\text { against fire or explosion. }\end{array}$ \\
\hline
\end{tabular}

(c) When transuranic waste is packaged, defense waste See (1) above. shall be packaged separately from non-defense waste, if feasible.

(d) Containers of transuranic waste shall be marked such See (1) above. that their contents can be identified.

(2) Transportation. To the extent practical, the volume of waste and number of transuranic waste shipments shall be minimized.

From DOE G 435.1-1 Chapter III: Compliance with this requirement can be demonstrated by a combination of site procedures directing the efficient use of waste container capacity and documentation showing that transuranic waste shipments are systematically planned and make optimal use of the shipment system (e.g., TRUPACT II) to the extent practical.

M. Site Evaluation and Facility Design. The following requirements are in addition to those in Chapter I of this Manual.

NA; waste is not shipped from this facility to an offsite facility for final disposition.

(1) Site Evaluation. Proposed locations for transuranic waste facilities shall be evaluated to identify relevant features that should be avoided or must be considered in facility design and analyses.

(a) Each site proposed for a new transuranic waste facility or expansion of an existing transuranic waste facility shall be evaluated considering environmental characteristics, geotechnical characteristics, and human activities.

(b) Proposed sites with environmental characteristics, geotechnical characteristics, and human activities for which adequate protection cannot be provided through facility design shall be deemed unsuitable for the location of the facility.

(2) Facility Design. The following facility requirements See M. above. and general design criteria, at a minimum, apply:

(a) Confinement. Transuranic waste systems and components shall be designed to maintain waste confinement.

(b) Ventilation.

NA; this requirement addresses new radioactive waste management facilities or modifications to existing facilities.

See M. above.

See M. above.

See M. above.

1 Design of transuranic waste treatment and storage facilities shall include ventilation, if applicable, through an appropriate filtration system to maintain the release of radioactive material in airborne effluents within the

See M. above.

See M. above.

See M. above. 
Table 1. (continued).

TRA-605 Radioactive Materials Storage Area

\begin{tabular}{l}
\hline \multicolumn{1}{|c|}{ Chapter III, Transuranic Waste Requirements } \\
\hline $\begin{array}{l}\text { requirements and guidelines specified in applicable } \\
\text { requirements. }\end{array}$ \\
$\begin{array}{l}2 \text { When conditions exist for generating gases in } \\
\text { flammable or explosive concentrations in treatment or } \\
\text { storage facilities, ventilation or other measures shall be } \\
\text { provided to keep the gases in a non-flammable and non- } \\
\text { explosive condition. Where concentrations of explosive } \\
\text { or flammable gases are expected to approach the lower } \\
\text { flammability limit, measures shall be taken to prevent } \\
\text { deflagration or detonation. }\end{array}$ \\
\hline
\end{tabular}

(c) Consideration of Decontamination and Decommissioning. Areas in new and modifications to existing transuranic waste management facilities that are subject to contamination with radioactive or other hazardous materials shall be designed to facilitate decontamination. For such facilities a proposed decommissioning method or a conversion method leading to reuse shall be described.

(d) Instrumentation and Control Systems. Engineering controls shall be incorporated in the design and engineering of transuranic waste treatment and storage facilities to provide volume inventory data and to prevent spills, leaks, and overflows from tanks or confinement systems.

(e) Monitoring. Monitoring and/or leak detection capabilities shall be incorporated in the design and engineering of transuranic waste storage, treatment, and disposal facilities to provide rapid identification of failed confinement and/or other abnormal conditions.

N. Storage. The following requirements are in addition to those in Chapter I of this Manual.

(1) Storage Prohibitions. Transuranic waste in storage shall not be readily capable of detonation, explosive decomposition, reaction at anticipated pressures and temperatures, or explosive reaction with water. Prior to storage, pyrophoric materials shall be treated, prepared, and packaged to be nonflammable.

From DOE G 435.1-1 Chapter III: Compliance with this requirement is demonstrated by having waste acceptance requirements which prohibit waste that is ignitable or explosive from being accepted for storage unless it has been treated.

(2) Storage Integrity. Transuranic waste shall be stored in a location and manner that protects the integrity of waste for the expected time of storage and minimizes worker exposure.

From DOE G 435.1-1 Chapter III: Compliance with this

Facility Compliance Information

See M. above.

See M. above.

See M. above.

See M. above.

See below.

IAG-443, Appendix A, addresses limitations on chemicals that can be stored in the facility.

LWP-15011 $§ 5$ provides general radioactive storage area requirements and $\$ 5.1 .7$ addresses outdoor storage of radioactive material. 
Table 1. (continued).

TRA-605 Radioactive Materials Storage Area

Chapter III, Transuranic Waste Requirements

requirement is demonstrated if sites have storage capabilities for transuranic waste that provide protection of waste containers so that their integrity will not be damaged through physical or chemical (corrosion) processes and that keep personnel from spending extended periods of time in the areas where transuranic waste is stored.

(3) Container Inspection. A process shall be developed and implemented for inspecting and maintaining containers of transuranic waste to ensure container integrity is not compromised.

From DOE G 435.1-1 Chapter III: Compliance with this requirement is demonstrated by a documented process for waste container inspection and maintenance at every facility managing transuranic waste, and documentation for all waste container inspections and maintenance actions performed.

(4) Retrievable Earthen-Covered Storage. Plans for the removal of transuranic waste from retrievable earthencovered storage facilities shall be established and maintained. Prior to commencing waste retrieval activities, each waste storage site shall be evaluated to determine relevant information on types, quantities, and location of radioactive and hazardous chemicals as necessary to protect workers during the retrieval process.

O. Treatment. Transuranic waste shall be treated as necessary to meet the waste acceptance requirements of the facility receiving the waste for storage or disposal.

From DOE G 435.1-1 Chapter III: Compliance with this requirement is demonstrated by the custodian of transuranic waste maintaining documentation which identifies the plans for treating waste, and maintaining the records that show waste was treated, if necessary, to meet the waste acceptance requirements of the storage or disposal facility to which it was transferred.

P. Disposal. Transuranic waste shall be disposed in accordance with the requirements of 40 CFR Part 191, Environmental Radiation Protection Standards for Management and Disposal of Spent Nuclear Fuel, HighLevel and Transuranic Radioactive Wastes.

Q. Monitoring. The following requirements are in addition to those in Chapter I of this Manual.

(1) All Waste Facilities. Parameters that shall be sampled or monitored, at a minimum, include: temperature, pressure (for closed systems), radioactivity in ventilation exhaust and liquid effluent streams, and

LI-435 requires quarterly inspections of radioactive waste containers if waste is stored outdoors or has been in storage for greater than 1 year.
NA; this facility is not an earthen-covered storage facility.
NA; TRU waste is not treated at this facility.

NA; TRU waste is not disposed of at this facility.
See (1), (2), and (3) below.

Monitoring requirements at INL radioactive waste management facilities are tailored for the specific facility to enable timely indication of developing problems. Existing radiological control procedures and assessments 
Table 1. (continued).

TRA-605 Radioactive Materials Storage Area

Chapter III, Transuranic Waste Requirements

flammable or explosive mixtures of gases. Facility monitoring programs shall include verification that passive and active control systems have not failed.

From DOE G 435.1-1 Chapter III: If a minimum parameter specified in the requirement is deemed to be not applicable in any way to the active operation of that facility, then that justification should be included in the radioactive waste management basis and when approved, constitutes an exemption to the Manual.

Verification activities are part of the radioactive waste management basis and are to be documented appropriately.

Compliance with this requirement is demonstrated if monitoring or sampling for the stated parameters is performed for all facilities with an accuracy, precision, and frequency consistent with timely identification of developing problems and a justification exists in the approved radioactive waste management basis for those specified parameters which are not monitored or sampled.

(2) Stored Wastes. All transuranic wastes in storage shall be monitored, as prescribed by the appropriate facility safety analysis, to ensure the wastes are maintained in safe condition.

From DOE G 435.1-1 Chapter III: Compliance with this requirement is demonstrated if the monitoring requirements in the facility procedures include, at a minimum, monitoring the systems and parameters as indicated by the safety analysis.
Facility Compliance Information are followed/completed to monitor waste facilities.

LRD-15001 and MCP-139 specify methods and frequency of radiological control surveys of all radiological areas. MCP-139 specifies the use of Form 441.A34. This form is referred to as the "routine sheet" and is to be used by facility radiological control foremen to list radiological areas that are to be surveyed, the survey periods, and methods.
HAD-277 $\$ 3.1$ states that the hazards associated with radiological material are controlled and monitored by an inventory control program and by the INL Radiation Protection Program.

SD-24.1.3, Appendix B provides the procedure for ensuring that stored waste limits are not exceeded and delegates this responsibility to the Radioactive Material Storage Area custodian.

IAG-443 establishes WGS as the Radioactive Material Storage Area custodian. Appendix A, Article II outlines requirements for controlling radiological material inventories.

(3) Liquid Waste Storage Facilities. For facilities storing NA; liquid TRU waste is not stored at this facility. liquid transuranic waste, the following shall also be monitored: liquid level and/or waste volume, and significant waste chemistry parameters.

From DOE G 435.1-1 Chapter III: Compliance with this requirement is demonstrated by developing operational procedures for monitoring liquid transuranic waste storage tank liquid level, waste volume, and tank chemistry so that waste volume or chemistry changes are detected in a time frame that will allow implementation of corrective measures to limit public and worker doses and to mitigate unplanned releases of stored liquid waste. 
Table 2. TRA-605 Radioactive Materials Storage Area DOE Manual 435.1-1 low-level waste requirements and facility compliance information.

\begin{tabular}{|c|c|}
\hline \multicolumn{2}{|c|}{ Facility Name: TRA-605 Radioactive Materials Storage Area } \\
\hline Chapter IV, LLW Requirements & Facility Compliance Information \\
\hline $\begin{array}{l}\text { A. Definition of Low-Level Waste. Low-level } \\
\text { radioactive waste is radioactive waste that is not high- } \\
\text { level radioactive waste, spent nuclear fuel, transuranic } \\
\text { waste, byproduct material (as defined in section 11e.( } 2 \text { ) } \\
\text { of the Atomic Energy Act of 1954, as amended), or } \\
\text { naturally occurring radioactive material. } \\
\text { (From DOE G } 435.1-1 \text { Chapter IV: Low-level } \\
\text { radioactive waste is defined by what it is not. The } \\
\text { guidance on definitions in Chapters II and III should be } \\
\text { consulted first for making a determination on how to } \\
\text { properly manage a suspect waste stream.) }\end{array}$ & $\begin{array}{l}\text { This requirement provides the criteria for determining } \\
\text { which DOE radioactive waste is to be managed as LLW } \\
\text { in accordance with DOE Manual 435.1-1 Chapter IV. } \\
\text { Radioactive waste managed at this facility under the } \\
\text { requirements of this chapter is not managed under the } \\
\text { requirements of DOE Manual } 435.1-1 \text { Chapter II or } \\
\text { Chapter III. }\end{array}$ \\
\hline $\begin{array}{l}\text { B. Management of Specific Wastes. The following } \\
\text { provide for management of specific wastes as low-level } \\
\text { waste in accordance with the requirements in this } \\
\text { Chapter: }\end{array}$ & See below. \\
\hline $\begin{array}{l}\text { (1) Mixed Low-Level Waste. Low-level waste } \\
\text { determined to contain both source, special nuclear, or } \\
\text { byproduct material subject to the Atomic Energy Act of } \\
1954 \text {, as amended, and a hazardous component subject to } \\
\text { the Resource Conservation and Recovery Act (RCRA), } \\
\text { as amended, shall be managed in accordance with the } \\
\text { requirements of RCRA and DOE O 435.1, Radioactive } \\
\text { Waste Management, and this Manual. }\end{array}$ & NA. This facility does not manage mixed LLW. \\
\hline $\begin{array}{l}\text { (2) TSCA-Regulated Waste. Low-level waste containing } \\
\text { polychlorinated biphenyls, asbestos, or other such } \\
\text { regulated toxic components shall be managed in } \\
\text { accordance with requirements derived from the Toxic } \\
\text { Substances Control Act, as amended, DOE O 435.1, } \\
\text { Radioactive Waste Management, and this Manual. }\end{array}$ & $\begin{array}{l}\text { This facility may manage TSCA-regulated waste. } \\
\text { Compliance with TSCA regulations is addressed by } \\
\text { WGS in its waste management services role in } \\
\text { MCP-17000 and MCP-17410. }\end{array}$ \\
\hline $\begin{array}{l}\text { (3) Accelerator-Produced Waste. Radioactive waste } \\
\text { produced as a result of operations of DOE accelerators is } \\
\text { low-level waste and shall be managed in accordance with } \\
\text { DOE O 435.1, Radioactive Waste Management, and this } \\
\text { Manual, and all applicable Federal or State requirements. }\end{array}$ & $\begin{array}{l}\text { NA; this facility does not manage accelerator-produced } \\
\text { waste. }\end{array}$ \\
\hline $\begin{array}{l}\text { (4) } 11 \text { e.(2) and Naturally Occurring Radioactive } \\
\text { Material. Small quantities of } 11 \text { e.(2) byproduct material } \\
\text { and naturally occurring radioactive material may be } \\
\text { managed as low-level waste provided they can be } \\
\text { managed to meet the requirements for low-level waste } \\
\text { disposal in Section IV.P of this Manual. }\end{array}$ & $\begin{array}{l}\text { NA; this facility does not manage naturally occurring } \\
\text { radioactive material. }\end{array}$ \\
\hline $\begin{array}{l}\text { C. Complex-Wide Low-Level Waste Management } \\
\text { Program. A complex-wide program and plan shall be } \\
\text { developed as described under Responsibilities, } 2 . B \text { and } \\
\text { 2.D, in Chapter I of this Manual. }\end{array}$ & $\begin{array}{l}\text { Not a facility-specific requirement. DOE Manual 435.1- } \\
1 \S \text { I.2.B and } \S \text { I.2.D apply to the Assistant Secretary for } \\
\text { Environmental Management and the Deputy Assistant } \\
\text { Secretary for Waste Management, respectively. }\end{array}$ \\
\hline
\end{tabular}


Table 2. (continued).

\begin{tabular}{|c|c|}
\hline \multicolumn{2}{|c|}{ Facility Name: TRA-605 Radioactive Materials Storage Area } \\
\hline Chapter IV, LLW Requirements & Facility Compliance Information \\
\hline $\begin{array}{l}\text { D. Radioactive Waste Management Basis. Low-level } \\
\text { waste facilities, operations, and activities shall have a } \\
\text { radioactive waste management basis consisting of } \\
\text { physical and administrative controls to ensure the } \\
\text { protection of workers, the public, and the environment. } \\
\text { The following specific waste management controls shall } \\
\text { be part of the radioactive waste management basis: }\end{array}$ & $\begin{array}{l}\text { The RWMB provides the regulatory framework for } \\
\text { management of radioactive waste at INL. It specifically } \\
\text { identifies facility management and implementing } \\
\text { documents for the generation, storage, treatment, and } \\
\text { disposal of radiological waste. } \\
\text { LLW management is addressed in PDD-17000. Routine } \\
\text { waste management activities are conducted in } \\
\text { accordance with LI- } 435 \text {. } \\
\text { This facility is a LTHC3 facility (HAD-277). } \\
\text { SD-24.1.3 identifies administrative controls, a method of } \\
\text { compliance, and the responsible organization so that the } \\
\text { hazard classification is maintained. }\end{array}$ \\
\hline $\begin{array}{l}\text { (1) Generators. The waste certification program. } \\
\text { From DOE G 435.1-1 Chapter IV: For a facility that } \\
\text { generates low-level waste, the radioactive waste } \\
\text { management basis is to include the program for } \\
\text { certifying that waste meets the waste acceptance } \\
\text { requirements of the facility(ies) to which the waste will } \\
\text { be sent. }\end{array}$ & NA; LLW is not generated at this facility. \\
\hline $\begin{array}{l}\text { (2) Treatment Facilities. certification program. The waste } \\
\text { acceptance requirements and the waste }[\text { sic }]\end{array}$ & NA; LLW is not treated at this facility. \\
\hline $\begin{array}{l}\text { From DOE G } 435.1-1 \text { Chapter IV: Facilities that store or } \\
\text { treat low-level waste are to have approved waste } \\
\text { acceptance requirements (see DOE M } 435.1-1 \text {, Section } \\
\text { IV.G) prior to the issuance of a radioactive waste } \\
\text { management basis. }\end{array}$ & \\
\hline $\begin{array}{l}\text { A facility that stores or treats waste also is generally } \\
\text { expected to have a waste certification program. Waste } \\
\text { from these facilities will have to be certified as meeting } \\
\text { the waste acceptance requirements of the facility to } \\
\text { which it will be transferred, and the facilities have the } \\
\text { potential for generating radioactive waste (e.g., } \\
\text { secondary processing streams from treatment, monitoring } \\
\text { and sampling, radioactive release cleanup). } \\
\text { Consequently, storage and treatment facilities should } \\
\text { also have an approved waste certification program as part } \\
\text { of their radioactive waste management basis. }\end{array}$ & \\
\hline $\begin{array}{l}\text { As part of the radioactive waste management basis, site } \\
\text { personnel needs to implement a system or process for } \\
\text { tracking the waste inventory at a storage, treatment, or } \\
\text { disposal facility. }\end{array}$ & \\
\hline $\begin{array}{l}\text { (3) Storage Facilities. The waste acceptance } \\
\text { requirements and the waste certification program. }\end{array}$ & $\begin{array}{l}\text { See G. and J. below for waste acceptance and waste } \\
\text { certification program requirements. }\end{array}$ \\
\hline $\begin{array}{l}\text { From DOE G } 435.1-1 \text { Chapter IV: Facilities that store or } \\
\text { treat low-level waste are to have approved waste }\end{array}$ & $\begin{array}{l}\text { HAD- } 277 \text { establishes the facility as a LTHC3 facility } \\
\text { and requires the facility manager to implement a method }\end{array}$ \\
\hline
\end{tabular}


Table 2. (continued).

Facility Name: TRA-605 Radioactive Materials Storage Area

\begin{tabular}{l} 
Chapter IV, LLW Requirements \\
\hline \multicolumn{1}{|c|}{ acceptance requirements (see DOE M 435.1-1, Section } \\
IV.G) prior to the issuance of a radioactive waste \\
management basis.
\end{tabular}

A facility that stores or treats waste also is generally expected to have a waste certification program. Waste from these facilities will have to be certified as meeting the waste acceptance requirements of the facility to which it will be transferred, and the facilities have the potential for generating radioactive waste (e.g., secondary processing streams from treatment, monitoring and sampling, radioactive release cleanup).

Consequently, storage and treatment facilities should also have an approved waste certification program as part of their radioactive waste management basis.

As part of the radioactive waste management basis, site personnel needs to implement a system or process for tracking the waste inventory at a storage, treatment, or disposal facility.

(4) Disposal Facilities. The performance assessment, composite analysis, disposal authorization statement, closure plan, waste acceptance requirements, and monitoring plan.

E. Contingency Actions. The following requirements are in addition to those in Chapter I of this Manual [DOE M 435.1-1 §I.1.E(5)].

(1) Contingency Storage. For off-normal or emergency situations involving high activity or high hazard liquid low-level waste storage or treatment, spare capacity with adequate capabilities shall be maintained to receive the largest volume of liquid contained in any one storage tank or treatment facility. Tanks or other facilities that are designated low-level waste contingency storage shall be maintained in an operational condition when waste is present and shall meet the requirements of DOE O 435.1, Radioactive Waste Management, and this Manual.

From DOE G 435.1-1 Chapter IV: Compliance with these requirements is demonstrated if adequate spare capacity and transfer equipment exists for emergency transfers of all high activity and high hazard liquid lowlevel waste. In addition, the capability to perform emergency transfers is demonstrated by having waste transfer routings identified, operational procedures to direct transfers, staff trained to the procedures, and records showing that the spare capacity and transfer capability are kept in operating condition.

(2) Transfer Equipment. Pipelines and auxiliary facilities necessary for the transfer of high activity or high hazard of tracking and controlling the radioactive material inventory so that the sum-of-the-ratios does not exceed 1.

SD-24.1.3, Appendix B addresses the use of IWTS to track the radionuclide quantity limits and the establishment of an alarm/warning limit in IWTS.

MCP-17000 $\$ 4$ specifies the use of IWTS, which tracks the waste inventory.
NA; this facility is not a disposal facility.

Not a facility-specific requirement. DOE Manual 435.1-

1 II.1.E(5) addresses the site-wide emergency management system. The INL plan is provided in PLN-114.

$\mathrm{NA}$; this facility does not store or treat liquid waste in tanks.
NA; this facility does not store or treat liquid waste in tanks. 
Table 2. (continued).

Facility Name: TRA-605 Radioactive Materials Storage Area

\begin{tabular}{|c|c|}
\hline Chapter IV, LLW Requirements & Facility Compliance Information \\
\hline $\begin{array}{l}\text { liquid low-level waste to contingency storage shall be } \\
\text { maintained in an operational condition when waste is } \\
\text { present and shall meet the requirements of DOE O 435.1, } \\
\text { Radioactive Waste Management, and this Manual. } \\
\text { From DOE G } 435.1-1 \text { Chapter IV: Compliance with } \\
\text { these requirements is demonstrated if adequate spare } \\
\text { capacity and transfer equipment exists for emergency } \\
\text { transfers of all high activity and high hazard liquid low- } \\
\text { level waste. In addition, the capability to perform } \\
\text { emergency transfers is demonstrated by having waste } \\
\text { transfer routings identified, operational procedures to } \\
\text { direct transfers, staff trained to the procedures, and } \\
\text { records showing that the spare capacity and transfer } \\
\text { capability are kept in operating condition. }\end{array}$ & \\
\hline $\begin{array}{l}\text { F. Corrective Actions. I of this Manual. The following } \\
\text { requirements are in addition to those in Chapter [sic] } \\
\text { From DOE G 435.1-1 Chapter IV: Compliance with } \\
\text { DOE M 435.1-1 §I.2.G.(1) is demonstrated by records } \\
\text { showing what corrective actions were taken to remedy } \\
\text { situations in the radioactive waste management system. } \\
\text { Compliance with DOE M } 435.1-1 \S \text { I.2.G.(2) is } \\
\text { demonstrated by having the necessary procedures, } \\
\text { mechanisms, and training in place to effect shutdown or } \\
\text { curtailment of activities which pose an imminent danger } \\
\text { or other serious hazard to workers or the public, or are } \\
\text { not protective of the environment. }\end{array}$ & $\begin{array}{l}\text { The INL-wide procedure addressing problem } \\
\text { identification as required by DOE Manual } 435.1-1 \\
\text { §I.2.G.(1) is LWP-13840, which implements the } \\
\text { laboratory's corrective action system. } \\
\text { The INL-wide procedure addressing shutdown or } \\
\text { curtailment of activities as required by DOE } \\
\text { Manual 435.1-1 §I.2.G.(2) is LWP-14002. }\end{array}$ \\
\hline $\begin{array}{l}\text { (1) Order Compliance. Corrective actions shall be } \\
\text { implemented whenever necessary to ensure the } \\
\text { requirements of DOE O 435.1, Radioactive Waste } \\
\text { Management, and this Manual are met. } \\
\text { From DOE G 435.1-1 Chapter IV: If a facility or activity } \\
\text { can be allowed to operate while a noncompliant or } \\
\text { hazardous condition exists, the allowance and any } \\
\text { associated limitations must be defined as part of the } \\
\text { facility or activity's radioactive waste management basis, } \\
\text { identified as a configuration controlled item in a } \\
\text { configuration management plan or included in a revision } \\
\text { or modification to an operating procedure or similar } \\
\text { controlled documentation. } \\
\text { Compliance with this requirement is demonstrated if a } \\
\text { corrective action system addresses noncompliant or } \\
\text { hazardous situations involving low-level waste } \\
\text { management facilities in a systematic fashion, and allows } \\
\text { identification of problems by all personnel. }\end{array}$ & See F. above. \\
\hline $\begin{array}{l}\text { (2) Operations Curtailment. Operations shall be curtailed } \\
\text { or facilities shut down for failure to establish, maintain, } \\
\text { or operate consistent with an approved radioactive waste }\end{array}$ & $\begin{array}{l}\text { The approved RWMB establishes the current } \\
\text { compliance status at each radioactive waste management } \\
\text { facility. Facility assessments are scheduled to ensure }\end{array}$ \\
\hline
\end{tabular}


Table 2. (continued).

Facility Name: TRA-605 Radioactive Materials Storage Area

\begin{tabular}{l}
\hline \multicolumn{1}{c|}{ Chapter IV, LLW Requirements } \\
\hline management basis. \\
From DOE G 435.1-1 Chapter IV: Compliance with this \\
requirement is demonstrated with a documented system \\
of routine assessments to determine whether waste \\
management activities and facilities are operating in \\
accordance with an approved radioactive waste \\
management basis that provides for graded limitations \\
that can be placed on activities and operations that do not \\
have, or are operating outside of, an approved radioactive \\
waste management basis, including shutdown of the \\
facility.
\end{tabular}

G. Waste Acceptance. The following requirements are in addition to those in Chapter I of this Manual [DOE M 435.1-1 §I.2.F(6)].

(1) Technical and Administrative. Waste acceptance requirements for all low-level waste storage, treatment, or disposal facilities, operations, and activities shall specify, at a minimum, the following:

From DOE G 435.1-1 Chapter IV: Compliance with these waste acceptance requirements is demonstrated if they are documented, contain clear and precise criteria specifying the radionuclide limits in the form of contents or concentrations that can be accepted, the limitations and prohibitions on waste forms and packages that can be received, and the limits, prohibitions, or instructions concerning any other technical information so that the waste is compatible with the safety basis of the facility, and which will result in acceptable waste at subsequent steps in managing the low-level waste.

Not a facility-specific requirement. DOE Manual 435.1$1 \S$ I.2.F(6) applies to field element managers.

HAD-277 establishes the facility as a LTHC3 facility and requires the facility manager to implement a method of tracking and controlling the radioactive material inventory so that the sum-of-the-ratios does not exceed 1.

SD-24.1.3, Appendix B provides the procedure for ensuring that stored waste limits are not exceeded and delegates this responsibility to the Radioactive Material Storage Area custodian.

IAG-443 establishes WGS as the Radioactive Material Storage Area custodian. Appendix A, Article II outlines requirements for controlling radiological material inventories.

The Radioactive Material Storage Area custodian manages LLW in accordance with MCP-17000.

(a) Allowable activities and/or concentrations of specific See (1) above. radionuclides.

(b) Acceptable waste form and/or container requirements See (1) above. that ensure the chemical and physical stability of waste under conditions that might be encountered during transportation, storage, treatment, or disposal.

(c) Restrictions or prohibitions on waste, materials, or containers that may adversely affect waste handlers or compromise facility or waste container performance.

(d) The following are additional waste acceptance requirements that shall be specified in low-level waste disposal facility waste acceptance requirements:

1 Low-level waste must contribute to and not detract from achieving long-term stability of the facility, minimizing the need for long-term active maintenance, minimizing subsidence, and minimizing contact of water

See (1) above.

NA; this facility is not a LLW disposal facility.
See (d) above. 
Table 2. (continued).

Facility Name: TRA-605 Radioactive Materials Storage Area

\begin{tabular}{l}
\hline \multicolumn{1}{|c|}{ Chapter IV, LLW Requirements } \\
\hline with waste. Void spaces within the waste and, if \\
containers are used, between the waste and its container \\
shall be reduced to the extent practical. \\
\hline 2 Liquid low-level waste or low-level waste containing \\
free liquid must be converted into a form that contains as \\
little freestanding liquid as is reasonably achievable, but \\
in no case shall the liquid exceed 1 percent of the waste \\
volume when the low-level waste is in a disposal \\
container, or 0.5 percent of the waste volume after it is \\
processed to a stable form. \\
3 Low-level waste must not be readily capable of \\
detonation or of explosive decomposition or reaction at \\
anticipated pressures and temperatures, or of explosive \\
reaction with water. Pyrophoric materials contained in \\
waste shall be treated, prepared, and packaged to be \\
nonflammable.
\end{tabular}

4 Low-level waste must not contain, or be capable of generating by radiolysis or biodegradation, quantities of toxic gases, vapors, or fumes harmful to the public or workers or disposal facility personnel, or harmful to the long-term structural stability of the disposal site.

5 Low-level waste in a gaseous form must be packaged such that the pressure does not exceed 1.5 atmospheres absolute at $20 \mathrm{C}$. [sic]

(e) The basis, procedures, and levels of authority required for granting exceptions to the waste acceptance requirements, which shall be contained in each facility's waste acceptance documentation. Each exception request shall be documented, including its disposition as approved or not approved.

From DOE G 435.1-1 Chapter IV: Waste acceptance requirements are acceptable if they are documented and contain a clear description of the procedure and bases for obtaining an exception or deviation to the acceptance criteria for low-level waste to be received at the facility.

(2) Evaluation and Acceptance. The receiving facility shall evaluate waste for acceptance, including confirmation that the technical and administrative requirements have been met. A process for the disposition of non-conforming wastes shall be established.

From DOE G 435.1-1 Chapter IV: Compliance with the waste acceptance requirements for a low-level waste management facility is demonstrated if they include a process for evaluation and acceptance of incoming waste to ensure the acceptance criteria of the facility receiving the waste are met that includes one of or a combination 
Table 2. (continued).

Facility Name: TRA-605 Radioactive Materials Storage Area

\begin{tabular}{l} 
Chapter IV, LLW Requirements \\
\hline of: (1) testing, sampling, and analysis of representative \\
samples of waste upon receipt; (2) testing, sampling, and \\
analysis of split samples of waste taken at the generator \\
site; (3) evaluation of testing, sampling, and analysis of \\
data provided by the generator, or (4) audits, reviews, \\
surveillance, or observations of generator waste \\
certification programs and characterization activities. \\
Additionally, acceptable waste acceptance requirements \\
for a storage, treatment or disposal facility will have \\
documented procedures and actions to be taken if a waste \\
that does not conform to the waste acceptance criteria is \\
received at the facility.
\end{tabular}

H. Waste Generation Planning. The following

Not a facility-specific requirement. DOE Manual 435.1requirements are in addition to those in Chapter I of this 1 §I.2.F(7) applies to field element managers. Manual [DOE M 435.1-1 §I.2.F(7)].

(1) Life-Cycle Planning. Prior to waste generation, planning shall be performed to address the entire life cycle for all low-level waste streams.

From DOE G 435.1-1 Chapter IV: Compliance with this planning requirement is demonstrated by the individual sites establishing a process for evaluating the life-cycle of low-level waste prior to its generation, including the identification of low-level wastes with no path to disposal and appropriate records justifying the newly generated low-level waste stream(s), and site personnel possessing planning information showing the location(s) where low-level waste will be stored, treated, and/or disposed along with a confirmation that the personnel managing the facilities agree that the low-level waste may be managed at those facilities.

(2) Waste with No Identified Path to Disposal. Low-level NA; LLW is not generated at this facility. waste streams with no identified path to disposal shall be generated only in accordance with approved conditions which, at a minimum, shall address:

(a) Programmatic need to generate the waste;

See (2) above. (b) Characteristics and issues preventing the disposal of $\quad$ See (2) above. the waste;

(c) Safe storage of the waste until disposal can be achieved; and

(d) Activities and plans for achieving final disposal of the waste.

I. Waste Characterization. Low-level waste shall be characterized using direct or indirect methods, and the characterization documented in sufficient detail to ensure safe management and compliance with the waste acceptance requirements of the facility receiving the

NA; LLW is not generated at this facility.

See (2) above. See (2) above.

IAG-443 establishes WGS as the Radioactive Material Storage Area custodian.

IAG-443, Appendix B establishes WGS' functional responsibilities for waste, which are to arrange for the removal and disposition of waste generated and 
Table 2. (continued).

\begin{tabular}{|c|c|}
\hline \multicolumn{2}{|c|}{ Facility Name: TRA-605 Radioactive Materials Storage Area } \\
\hline Chapter IV, LLW Requirements & Facility Compliance Information \\
\hline waste. & characterized by others. \\
\hline $\begin{array}{l}\text { From DOE G 435.1-1 Chapter IV: Compliance with this } \\
\text { requirement is demonstrated by a program for } \\
\text { documenting and the existence of records that document } \\
\text { the process for acquiring and verifying the validity of } \\
\text { low-level waste characterization data acquired through } \\
\text { the use of direct or indirect methods. }\end{array}$ & $\begin{array}{l}\text { MCP-17000 addresses waste characterization. This is } \\
\text { done using Form } 435.39 \text {. The facility also uses } \\
\text { Form } 435.42 \text { to characterize and serve as the } \\
\text { characterization record for this waste. }\end{array}$ \\
\hline $\begin{array}{l}\text { (1) Data Quality Objectives. The data quality objectives } \\
\text { process, or a comparable process, shall be used for } \\
\text { identifying characterization parameters and acceptable } \\
\text { uncertainty in characterization data. }\end{array}$ & $\begin{array}{l}\text { Radioactive waste management facilities characterize } \\
\text { waste in accordance with the requirements of the } \\
\text { receiving storage, treatment, or disposal facility.The } \\
\text { documented use of a data quality objectives process, or }\end{array}$ \\
\hline $\begin{array}{l}\text { From DOE G } 435.1-1 \text { Chapter IV: Compliance with this } \\
\text { requirement is demonstrated by the documented use of a } \\
\text { data quality objectives or a comparable process for } \\
\text { determining the type, quantity, and quality of } \\
\text { characterization data needed to safely manage low-level } \\
\text { waste. }\end{array}$ & comparable process, was not identified for this facility. \\
\hline $\begin{array}{l}\text { (2) Minimum Waste Characterization. Characterization } \\
\text { data shall, at a minimum, include the following } \\
\text { information relevant to the management of the waste: }\end{array}$ & $\begin{array}{l}\text { MCP-17000, including } \S \S 4.2,4.3 \text {, and } 4.4 \text {, provides } \\
\text { waste characterization requirements. Information on } \\
\text { absorbent media is required in } \S \S 4.5 \text { and } 4.7 \text {. }\end{array}$ \\
\hline $\begin{array}{l}\text { From DOE G } 435.1-1 \text { Chapter IV: Compliance with this } \\
\text { requirement is demonstrated by the existence of a } \\
\text { program or procedure for determining and records that } \\
\text { document characterization of low-level waste consistent } \\
\text { with the minimum characterization data requirements. }\end{array}$ & $\begin{array}{l}\text { MCP-17000 also specifies the use of IWTS, which } \\
\text { documents characterization data in an IWTS profile. }\end{array}$ \\
\hline (a) Physical and chemical characteristics; & See (2) above. \\
\hline $\begin{array}{l}\text { (b) Volume, including the waste and any stabilization or } \\
\text { absorbent media; }\end{array}$ & See (2) above. \\
\hline (c) Weight of the container and contents; & See (2) above. \\
\hline $\begin{array}{l}\text { (d) Identities, activities, and concentrations of major } \\
\text { radionuclides; }\end{array}$ & See (2) above. \\
\hline (e) Characterization date; & See (2) above. \\
\hline (f) Generating source; and & See (2) above. \\
\hline $\begin{array}{l}\text { (g) Any other information which may be needed to } \\
\text { prepare and maintain the disposal facility performance } \\
\text { assessment, or demonstrate compliance with applicable } \\
\text { performance objectives. }\end{array}$ & See (2) above. \\
\hline $\begin{array}{l}\text { J. Waste Certification. A waste certification program } \\
\text { shall be developed, documented, and implemented to } \\
\text { ensure that the waste acceptance requirements of } \\
\text { facilities receiving low-level waste for storage, treatment, } \\
\text { and disposal are met. } \\
\text { From DOE G 435.1-1 Chapter IV: Compliance with the } \\
\text { development and documentation portion of the }\end{array}$ & $\begin{array}{l}\text { MCP-17000 cites a waste certification program for LLW } \\
\text { destined for the Nevada National Security Site (NNSS). } \\
\text { For waste destined for locations other than NNSS, the } \\
\text { waste disposition specialist is responsible for certifying } \\
\text { the waste stream by ensuring the waste, as characterized, } \\
\text { falls within the limitations of the waste acceptance } \\
\text { criteria of the treatment, storage, or disposal facility }\end{array}$ \\
\hline
\end{tabular}


Table 2. (continued).

Facility Name: TRA-605 Radioactive Materials Storage Area

\begin{tabular}{|l|}
\hline \multicolumn{1}{|c|}{ Chapter IV, LLW Requirements } \\
\hline certification requirement is demonstrated by a waste \\
certification plan that identifies the organizations \\
involved, assigns responsibilities for implementing the \\
program, and describes or references the quality \\
assurance, training, procurement controls, records \\
management, and procedures to be used by the program. \\
Acceptable performance for implementing the program is \\
demonstrated when appropriate personnel are trained and \\
follow the procedures that govern their part of the waste \\
certification. Additionally, acceptable performance is \\
demonstrated if the waste certification plan and \\
procedures are current and controlled in accordance with \\
a document controls program, and records related to \\
certification (e.g., certification statements, training \\
records, procurement records, characterization records, \\
container records) are generated and managed in \\
accordance with the established site program.
\end{tabular}

(1) Certification Program. The waste certification program shall designate the officials who have the authority to certify and release waste for shipment; and specify what documentation is required for waste generation, characterization, shipment, and certification. The program shall provide requirements for auditability, retrievability, and storage of required documentation and specify the records retention period.

From DOE G 435.1-1 Chapter IV: Compliance with this requirement is demonstrated by a program or procedure for record keeping and records showing that low-level waste is certified as having met the waste acceptance criteria of the facility to which it was transferred and that the certification statement is supported by additional records regarding the waste source, characterization, and container.

(2) Certification before Transfer. Low-level waste shall be certified as meeting waste acceptance requirements before it is transferred to the facility receiving the waste.

See J. above. MCP-17500 $\$ 4.3 .6$ addresses controls for certification before transfer for LLW to be disposed of at NNSS.

$(\S 2)$.

Container procurement is addressed in MCP-17000 §4.6.

MCP-17500 provides the WGS waste certification program for LLW to be shipped to NNSS.

Waste certification is performed and tracked using IWTS. Documentation of the IWTS Program is available electronically only.

PLN-522 requires waste technical specialists and waste disposition specialists to complete the appropriate training/qualification before being granted approval authority for profiles within the IWTS Program. The waste certification official, alternate waste certification official, and NNSS packaging certifiers must complete the appropriate training/qualifications to disposition waste to NNSS.

See J. above. MCP-17500 $\S 2$ and 5 address certification records for shipments to NNSS.

From DOE G 435.1-1 Chapter IV: Compliance with this requirement is demonstrated by the presence of a certification program which includes procedures requiring a signed certification statement prior to the release of waste for transfer, and by dated records showing that waste was certified before being transferred.

(3) Maintaining Certification. Low-level waste that has been certified as meeting the waste acceptance requirements for transfer to a storage, treatment, or disposal facility shall be managed in a manner that maintains its certification status.

See J. above. Pre-certification checklists are cited in
MCP-17000 and MCP-17500. Surveillances also are
addressed in MCP-17500.
LWP-15011 $\$ 5$ provides general radioactive storage area
requirements and $\$ 5.1 .7$ addresses outdoor storage of 
Table 2. (continued).

\begin{tabular}{|c|c|}
\hline \multicolumn{2}{|c|}{ Facility Name: TRA-605 Radioactive Materials Storage Area } \\
\hline Chapter IV, LLW Requirements & Facility Compliance Information \\
\hline $\begin{array}{l}\text { From DOE G } 435.1-1 \text { Chapter IV: Compliance with this } \\
\text { requirement is demonstrated by a program or procedure } \\
\text { reflecting this requirement is present and site personnel } \\
\text { are able to show that the storage of low-level waste } \\
\text { containers is in a facility or manner where the containers } \\
\text { would not be damaged by normal weather events, and } \\
\text { cannot be accessed by unauthorized personnel. Further, } \\
\text { each container can be traced to its certification and the } \\
\text { information supporting that certification. }\end{array}$ & radioactive material. \\
\hline $\begin{array}{l}\text { K. Waste Transfer. A documented process shall be } \\
\text { established and implemented for transferring } \\
\text { responsibility for management of low-level waste and for } \\
\text { ensuring availability of relevant data. The following } \\
\text { requirements are in addition to those in Chapter I of this } \\
\text { Manual. } \\
\text { From DOE G } 435.1-1 \text { Chapter IV: Compliance with this } \\
\text { requirement is demonstrated if facilities have procedures } \\
\text { for the receipt of waste and the transfer of waste, as } \\
\text { appropriate, which address the acquisition of waste and } \\
\text { container data and the transfer of ownership, } \\
\text { respectively. Further evidence of acceptable performance } \\
\text { is facility records showing that data on the waste } \\
\text { containers is available and accurate, and that documented } \\
\text { transfer of responsibility occurs. }\end{array}$ & $\begin{array}{l}\text { Requirements controlling waste transfers into the facility } \\
\text { are established in SD-24.1.3 and in IAG- } 443 \text {. } \\
\text { MCP-17000 } \$ 4.8 .15 \text { specifies requirements for } \\
\text { interfacility transfers. } \\
\text { MCP-17500 } \$ 4 \text { addresses LLW to be transferred to } \\
\text { NNSS. }\end{array}$ \\
\hline $\begin{array}{l}\text { (1) Authorization. Low-level waste shall not be } \\
\text { transferred to a storage, treatment, or disposal facility } \\
\text { until personnel responsible for the facility receiving the } \\
\text { waste authorize the transfer. } \\
\text { From DOE G } 435.1-1 \text { Chapter IV: Compliance with this } \\
\text { requirement is demonstrated by sites having procedures } \\
\text { that require a confirmation of authorization before } \\
\text { releasing waste for transfer, and records showing that } \\
\text { transfers are made in accordance with written } \\
\text { authorizations. }\end{array}$ & See K. above. \\
\hline $\begin{array}{l}\text { (2) Data. Waste characterization data, container } \\
\text { information, and generation, storage, treatment, and } \\
\text { transportation information for low-level waste shall be } \\
\text { transferred with or be traceable to the waste. } \\
\text { From DOE G 435.1-1 Chapter IV: Compliance with this } \\
\text { requirement is demonstrated if there are procedures } \\
\text { requiring that characterization and container data be } \\
\text { provided and maintained for each low-level waste } \\
\text { transfer and documented records of transfers show that } \\
\text { the information is being provided. }\end{array}$ & See K. above. \\
\hline $\begin{array}{l}\text { L. Packaging and Transportation. The following } \\
\text { requirements are in addition to those in Chapter I of this } \\
\text { Manual [DOE M 435.1-1 §I.1.E(11)]. }\end{array}$ & See (1) and (2) below. \\
\hline
\end{tabular}


Table 2. (continued).

Facility Name: TRA-605 Radioactive Materials Storage Area

Chapter IV, LLW Requirements

(1) Packaging. If containers are used:

From DOE G 435.1-1 Chapter IV: Compliance with the packaging requirement is demonstrated by: (1) procedures which document proper packaging protocols; and (2) no trends of routine repackaging of low-level waste that is packaged after issuance of DOE O 435.1. Successful performance of this requirement is also demonstrated by a record of containers for which failure has not routinely occurred under management conditions. It is recognized that there may be failed containers for waste previously placed in storage. For those containers, the goal is to only have to repackage the waste one time after it is retrieved and characterized. Further, acceptable performance is demonstrated by containers of waste having marking and labeling that allows correlation with waste characterization data and container information.

(a) Low-level waste shall be packaged in a manner that provides containment and protection for the duration of the anticipated storage period and until disposal is achieved or until the waste has been removed from the container.

(b) When waste is packaged, vents or other measures shall be provided if the potential exists for pressurizing or generating flammable or explosive concentrations of gases within the waste container.

(c) Containers of low-level waste shall be marked such that their contents can be identified.

(2) Transportation. To the extent practical, the volume of waste and number of low-level waste shipments shall be minimized.

From DOE G 435.1-1 Chapter IV: Compliance with this requirement can be demonstrated by a combination of site procedures directing the efficient use of waste container capacity and documentation showing that lowlevel waste shipments are systematically planned and optimized to the extent practical.

M. Site Evaluation and Facility Design. The following requirements are in addition to those in Chapter I of this Manual.

(1) Site Evaluation. Proposed locations for low-level waste facilities shall be evaluated to identify relevant features that should be avoided or must be considered in facility design and analyses.

(a) Each site proposed for a new low-level waste facility or expansion of an existing low-level waste facility shall be evaluated considering environmental characteristics, geotechnical characteristics, and human activities,
See (1) above.

See (1) above.

See (1) above.

MCP-17000 $\$ 4$ addresses transportation. The waste disposition specialist coordinates with packaging and transportation personnel for waste shipped offsite from this facility.

Waste is shipped directly to NNSS from this facility. MCP-17500 specifies waste certification official and waste disposition specialist responsibilities and coordination with packaging and transportation personnel.

$\mathrm{NA}$; this requirement addresses new radioactive waste management facilities or modifications to existing facilities.

See M. above.

See M. above.

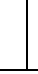

MCP-17000 $\$ 4$ addresses packaging requirements. 
Table 2. (continued).

Facility Name: TRA-605 Radioactive Materials Storage Area

\begin{tabular}{|l}
\hline \multicolumn{1}{|c|}{ Chapter IV, LLW Requirements } \\
\hline $\begin{array}{l}\text { including for a low-level waste disposal facility, the } \\
\text { capability of the site to demonstrate, at a minimum, } \\
\text { whether it is: }\end{array}$ \\
$\begin{array}{l}1 \text { Located to accommodate the projected volume of } \\
\text { waste to be received; }\end{array}$ \\
$\begin{array}{l}2 \text { Located in a flood plain, a tectonically active area, or } \\
\text { in the zone of water table fluctuation; and }\end{array}$ \\
$\begin{array}{l}3 \text { Located where radionuclide migration pathways are } \\
\text { predictable and erosion and surface runoff can be } \\
\text { controlled. }\end{array}$ \\
\hline
\end{tabular}

(b) Proposed sites with environmental characteristics, geotechnical characteristics, and human activities for which adequate protection cannot be provided through facility design shall be deemed unsuitable for the location of the facility.

(c) Low-level waste disposal facilities shall be sited to achieve long-term stability and to minimize, to the extent practical, the need for active maintenance following final closure.

(2) Low-Level Waste Treatment and Storage Facility Design. The following facility requirements and general design criteria, at a minimum, apply:

(a) Confinement. Low-level waste systems and components shall be designed to maintain waste confinement.

(b) Ventilation.

1 Design of low-level waste treatment and storage facilities shall include ventilation, if applicable, through an appropriate filtration system to maintain the release of radioactive material in airborne effluents within the requirements and guidelines specified in applicable requirements.

2 When conditions exist for generating gases in flammable or explosive concentrations, ventilation systems or other measures shall be provided to keep the gases in a non-flammable and nonexplosive condition. Where concentrations of explosive or flammable gases are expected to approach the lower flammability limit, measures shall be taken to prevent deflagration or detonation.

(c) Consideration of Decontamination and Decommissioning. Areas in new and modifications to existing low-level waste management facilities that are subject to contamination with radioactive or other hazardous materials shall be designed to facilitate
Facility Compliance Information

See M. above.

See M. above.

See M. above.

See M. above.

See M. above.

See M. above.

See M. above.

See M. above.

See M. above.

See M. above.

See M. above. 
Table 2. (continued).

Facility Name: TRA-605 Radioactive Materials Storage Area

\begin{tabular}{|l|}
\hline \multicolumn{1}{|c|}{ Chapter IV, LLW Requirements } \\
\hline decontamination. For such facilities a proposed \\
decommissioning method or a conversion method \\
leading to reuse shall be described.
\end{tabular}

(d) Instrumentation and Control Systems. Engineering controls shall be incorporated in the design and engineering of low-level waste treatment and storage facilities to provide volume inventory data and to prevent spills, leaks, and overflows from tanks or confinement systems.

(e) Monitoring. Monitoring and/or leak detection capabilities shall be incorporated in the design and engineering of low-level waste treatment and storage facilities to provide rapid identification of failed confinement and/or other abnormal conditions.

(3) Low-Level Waste Disposal Facility Design. The following facility requirements and general design criteria, at a minimum, apply:

(a) Confinement. Low-level waste systems and components shall be designed to maintain waste confinement.

(b) Ventilation.

1 Design of low-level waste disposal facilities shall include ventilation, if applicable, through an appropriate filtration system to maintain the release of radioactive material in airborne effluents within the requirements and guidelines specified in applicable requirements.

2 When conditions exist for generating gases in flammable or explosive concentrations, ventilation systems or other measures shall be provided to keep the gases in a nonflammable and non-explosive condition. Where concentrations of explosive or flammable gases are expected to approach the lower flammability limit, measures shall be taken to prevent deflagration or detonation.

(c) Stability. Low-level waste disposal facilities shall be designed to achieve long-term stability and to minimize to the extent practical, the need for active maintenance following final closure.

(d) Control of Water. Low-level waste disposal facilities shall be designed to minimize to the extent practical, the contact of waste with water during and after disposal.

N. Storage and Staging. The following requirements are in addition to those in Chapter I of this Manual [DOE M 435.1-1 §I.2.F(13)].

(1) Storage Prohibitions. Low-level waste in storage shall IAG-443, Appendix A addresses limitations on Facility Compliance Information

See M. above.

See M. above.

See M. above.

See M. above.

See M. above.

See M. above.

See M. above.

See M. above.

See M. above.

Not a facility-specific requirement. DOE Manual 435.1-

1 §I.2.F(13) applies to field element managers. 
Table 2. (continued).

Facility Name: TRA-605 Radioactive Materials Storage Area

\begin{tabular}{|l|}
\hline \multicolumn{1}{|c|}{ Chapter IV, LLW Requirements } \\
\hline not be readily capable of detonation, explosive \\
decomposition, reaction at anticipated pressures and \\
temperatures, or explosive reaction with water. Prior to \\
storage, pyrophoric materials shall be treated, prepared, \\
and packaged to be nonflammable. \\
From DOE G 435.1-1 Chapter IV: Compliance with this \\
requirement is demonstrated by having waste acceptance \\
requirements which prohibit low-level waste that is \\
ignitable or explosive from being accepted for storage \\
unless it has been treated, and procedures for properly \\
preparing such materials for safe storage.
\end{tabular}

(2) Storage Limit. Low-level waste that has an identified path to disposal shall not be stored longer than one year prior to disposal, except for storage for decay, or as otherwise authorized by the Field Element Manager.

From DOE G 435.1-1 Chapter IV: Storage longer than one year can be justified if the conditions for such storage are approved by the Field Element Manager as part of the radioactive waste management basis for the facility.

MCP-17000 $\$ 4.8 .16$ addresses storage time limits and waste that is to be stored longer than 1 year. Legacy remote-handled LLW is stored at this facility.

\section{COMPLIANCE CONSIDERATION}

DOE approval for storage longer than 1 year will be requested for continued storage of the remote-handled legacy LLW.

Form 435.A01 documents compliance inspections.

Storage for radioactive decay for a period greater than 1 year for waste that has an identified path to disposal is allowed. Adequate justification and the supporting information for storage for decay is to be documented in the radioactive waste management basis for the facility in which the storage will take place.

Mixed waste. Under the Federal Facility Compliance Act of 1992, DOE sites were required to develop Site Treatment Plans to bring stored mixed low-level waste into compliance with these requirements. The Site Treatment Plan needs to be consulted and any mixed low-level waste stored for the purpose of accumulation to facilitate treatment must meet Resource Conservation and Recovery Act storage requirements. There could be several ways within different scenarios that this requirement can be met, as illustrated by the examples below, however, there are basically four ways to show compliance with the requirement and include appropriate provisions in the radioactive waste management basis for the facility in which it is stored.

Legacy waste. As discussed above, the intention of the requirement is not to force malicious compliance or heroic actions which would result in increased risk or safety concerns. Rather, the intention is that waste in storage longer than one year receives additional attention to ensure that the public, the workers, and the environment are protected from the hazards of the waste, and that progress is being made to dispose of the waste. 
Table 2. (continued).

Facility Name: TRA-605 Radioactive Materials Storage Area

There could be several ways within different scenarios that this requirement can be met, as illustrated by the examples below, however, there are basically four ways to show compliance with the requirement:

1) the radioactive waste management basis allows for storage for no more than one year.

2) the radioactive waste management basis allows for storage for no more than one year, or for storage for decay only for periods greater than a year, which are specified on a radionuclide basis.

3) the radioactive waste management basis allows for storage for more than one year, up to a specified period of time based on a documented technical evaluation that the waste can be stored in a manner that does not cause changes to the waste or waste packages that is detrimental to the safe storage of the waste, the final disposal of the waste or to meeting the disposal performance objectives.

4) the radioactive waste management basis allows for storage for decay (with specifics) and for storage for more than one year for other low-level waste, up to a specified period of time based on a documented technical evaluation that the waste can be stored in a manner that does not cause changes to the waste or waste packages that is detrimental to the safe storage of the waste, the final disposal of the waste or to meeting the disposal performance objectives.

Compliance with this requirement is demonstrated by the existence of a radioactive waste management basis for the storage facility approved by the Field Element Manager that includes the time frames that waste are allowed to be stored, the necessary justifications for storage for decay, and the necessary technical evaluations if storage is to extend significantly beyond the one-year time frame.

(3) Storage Integrity. Low-level waste shall be stored in a location and manner that protects the integrity of waste for the expected time of storage and minimizes worker exposure.

LWP-15011 §5 provides general radioactive storage area requirements and $\S 5.1 .7$ addresses outdoor storage of radioactive material.

Form 435.A01 documents compliance inspections.

From DOE G 435.1-1 Chapter IV: However, in making a decision to use a facility for storage and in developing a radioactive waste management basis for the activity, particular attention to protection of workers is needed.

Compliance with this requirement is demonstrated if sites have storage capabilities for low-level waste that provide protection to waste containers so that their integrity will not be damaged through physical or 
Table 2. (continued).

Facility Name: TRA-605 Radioactive Materials Storage Area

\begin{tabular}{l} 
Chapter IV, LLW Requirements \\
\hline $\begin{array}{l}\text { chemical (corrosion) processes and that keep personnel } \\
\text { from spending extended periods of time in the areas } \\
\text { where low-level waste is stored. }\end{array}$ \\
(4) Waste Characterization for Storage. \\
(a) Low-level waste that does not have an identified path \\
to disposal shall be characterized as necessary to meet \\
the data quality objectives and minimum characterization \\
requirements of this Chapter, to ensure safe storage, and \\
to facilitate disposal.
\end{tabular}

(b) Characterization information for all low-level waste in storage shall be maintained as a record in accordance with the requirements for Records Management in Chapter I of this Manual.

From DOE G 435.1-1 Chapter IV: Compliance with this requirement is demonstrated by documented procedures for managing waste characterization and container information on low-level waste as a Federal record. The records are managed per the applicable policies and procedures for records management referenced in DOE O 200.1 and established at the applicable Field Element.

(5) Container Inspection. A process shall be developed and implemented for inspecting and maintaining containers of low-level waste to ensure container integrity is not compromised.

From DOE G 435.1-1 Chapter IV: Compliance with this requirement is demonstrated by: (1) a documented process for waste container inspection and maintenance; and (2) documentation for all waste container inspections and maintenance actions performed.

(6) Storage Management. Low-level waste storage shall be managed to identify and segregate low-level waste from mixed low-level waste.

(7) Staging. Staging of low-level waste shall be for the purpose of the accumulation of such quantities of waste as necessary to facilitate transportation, treatment, and disposal. Staging longer than 90 days shall meet the requirements for storage above and in Chapter I of this Manual.

From DOE G 435.1-1 Chapter IV: The staging of lowlevel waste needs to be addressed in the radioactive waste management basis for the facility that is performing the staging. Generators, treatment facilities, and disposal facilities that stage waste must ensure that the action of staging is included and authorized as part of their radioactive waste management basis for the affected facilities, operations, or activities.

Staging longer than 90 days must be justified, the

Facility Compliance Information

This facility does not store LLW that does not have an identified path to disposal.

SD-24.1.3 and MCP-17000 $\S \$ 4$ and 5 address the use of IWTS and records.

LI-435 requires quarterly inspections of radioactive waste containers if waste is stored outdoors or has been in storage for greater than 1 year.

Form 435.A01 documents compliance inspections.

NA; this facility does not store mixed LLW.

NA; waste is not staged at this facility. 
Table 2. (continued).

Facility Name: TRA-605 Radioactive Materials Storage Area

\begin{tabular}{l} 
Chapter IV, LLW Requirements \\
\hline conditions for such storage met, and these practices \\
approved by the Field Element Manager as part of the \\
radioactive waste management basis for the facility. \\
Compliance with this requirement is demonstrated by a \\
staging program that limits the temporary storage of \\
waste to only circumstances allowed in the requirement, \\
including justifications for any staging that exceeds the \\
90-day period, which is documented in the radioactive \\
waste management basis for the facility.
\end{tabular}

O. Treatment. Low-level waste treatment to provide more stable waste forms and to improve the long-term performance of a low-level waste disposal facility shall be implemented as necessary to meet the performance objectives of the disposal facility.

From DOE G 435.1-1 Chapter IV: Compliance with this requirement is demonstrated when a treatment facility or process ensures that treated waste will meet the minimum waste form requirements of DOE M 435.1 and meet additional disposal facility-specific waste acceptance requirements for additional stability or longterm performance of facilities that will receive the treated waste.

P. Disposal. Low-level waste disposal facilities shall meet the following requirements.

(1) Performance Objectives. Low-level waste disposal facilities shall be sited, designed, operated, maintained, and closed so that a reasonable expectation exists that the following performance objectives will be met for waste disposed of after September 26, 1988:

(a) Dose to representative members of the public shall not exceed $25 \mathrm{mrem}(0.25 \mathrm{mSv})$ in a year total effective dose equivalent from all exposure pathways, excluding the dose from radon and its progeny in air.

(b) Dose to representative members of the public via the See P. above. air pathway shall not exceed $10 \mathrm{mrem}(0.10 \mathrm{mSv})$ in a year total effective dose equivalent, excluding the dose from radon and its progeny.

(c) Release of radon shall be less than an average flux of See P. above. $20 \mathrm{pCi} / \mathrm{m}^{2} / \mathrm{s}\left(0.74 \mathrm{~Bq} / \mathrm{m}^{2} / \mathrm{s}\right)$ at the surface of the disposal facility. Alternatively, a limit of $0.5 \mathrm{pCi} / 1(0.0185 \mathrm{~Bq} / \mathrm{l})$ of air may be applied at the boundary of the facility.

(2) Performance Assessment. A site-specific radiological See P. above. performance assessment shall be prepared and maintained for DOE low-level waste disposed of after September 26, 1988. The performance assessment shall include calculations for a 1,000 year period after closure of potential doses to representative future members of the public and potential releases from the facility to provide 
Table 2. (continued).

Facility Name: TRA-605 Radioactive Materials Storage Area

\begin{tabular}{|l|l|}
\hline \multicolumn{1}{|c|}{ Chapter IV, LLW Requirements } & Facility Compliance Information \\
\hline $\begin{array}{l}\text { a reasonable expectation that the performance objectives } \\
\text { identified in this Chapter are not exceeded as a result of } \\
\text { operation and closure of the facility. }\end{array}$ & \\
\hline
\end{tabular}

(a) Analyses performed to demonstrate compliance with $\quad$ See P. above. the performance objectives in this Chapter, and to establish limits on concentrations of radionuclides for disposal based on the performance measures for inadvertent intruders in this Chapter shall be based on reasonable activities in the critical group of exposed individuals. Unless otherwise specified, the assumption of average living habits and exposure conditions in representative critical groups of individuals projected to receive the highest doses is appropriate. The likelihood of inadvertent intruder scenarios may be considered in interpreting the results of the analyses and establishing radionuclide concentrations, if adequate justification is provided.

(b) The point of compliance shall correspond to the point See P. above. of highest projected dose or concentration beyond a 100 meter buffer zone surrounding the disposed waste. A larger or smaller buffer zone may be used if adequate justification is provided.

(c) Performance assessments shall address reasonably foreseeable natural processes that might disrupt barriers against release and transport of radioactive materials.

(d) Performance assessments shall use DOE-approved dose coefficients (dose conversion factors) for internal and external exposure of reference adults.

(e) The performance assessment shall include a sensitivity/uncertainty analysis.

(f) Performance assessments shall include a demonstration that projected releases of radionuclides to the environment shall be maintained as low as reasonably achievable (ALARA).

(g) For purposes of establishing limits on radionuclides that may be disposed of near-surface, the performance assessment shall include an assessment of impacts to water resources.

(h) For purposes of establishing limits on the concentration of radionuclides that may be disposed of near-surface, the performance assessment shall include an assessment of impacts calculated for a hypothetical person assumed to inadvertently intrude for a temporary period into the low-level waste disposal facility. For intruder analyses, institutional controls shall be assumed to be effective in deterring intrusion for at least 100 years following closure. The intruder analyses shall use performance measures for chronic and acute exposure

See P. above.

See P. above.

See P. above.

See P. above.

See P. above.

See P. above. 
Table 2. (continued).

Facility Name: TRA-605 Radioactive Materials Storage Area

\begin{tabular}{|l|l|}
\hline \multicolumn{1}{|c|}{ Chapter IV, LLW Requirements } & Facility Compliance Information \\
\hline $\begin{array}{l}\text { scenarios, respectively, of } 100 \mathrm{mrem}(1 \mathrm{mSv}) \text { in a year } \\
\text { and } 500 \mathrm{mrem}(5 \mathrm{mSv}) \text { total effective dose equivalent } \\
\text { excluding radon in air. }\end{array}$ & \\
\hline
\end{tabular}

(3) Composite Analysis. For disposal facilities which received waste after September 26, 1988, a site-specific radiological composite analysis shall be prepared and maintained that accounts for all sources of radioactive material that may be left at the DOE site and may interact with the low- level waste disposal facility, contributing to the dose projected to a hypothetical member of the public from the existing or future disposal facilities. Performance measures shall be consistent with DOE requirements for protection of the public and environment and evaluated for a 1,000 year period following disposal facility closure. The composite analysis results shall be used for planning, radiation protection activities, and future use commitments to minimize the likelihood that current low- level waste disposal activities will result in the need for future corrective or remedial actions to adequately protect the public and the environment.

(4) Performance Assessment and Composite Analysis Maintenance. The performance assessment and composite analysis shall be maintained to evaluate changes that could affect the performance, design, and operating bases for the facility. Performance assessment and composite analysis maintenance shall include the conduct of research, field studies, and monitoring needed to address uncertainties or gaps in existing data. The performance assessment shall be updated to support the final facility closure. Additional iterations of the performance assessment and composite analysis shall be conducted as necessary during the post-closure period.

(a) Performance assessments and composite analyses shall be reviewed and revised when changes in waste forms or containers, radionuclide inventories, facility design and operations, closure concepts, or the improved understanding of the performance of the waste disposal facility in combination with the features of the site on which it is located alter the conclusions or the conceptual model(s) of the existing performance assessment or composite analysis.

(b) A determination of the continued adequacy of the performance assessment and composite analysis shall be made on an annual basis, and shall consider the results of data collection and analysis from research, field studies, and monitoring.

(c) Annual summaries of low-level waste disposal operations shall be prepared with respect to the conclusions and recommendations of the performance

See P. above.

See P. above.

See P. above.

See P. above.

See P. above. 
Table 2. (continued).

Facility Name: TRA-605 Radioactive Materials Storage Area

\begin{tabular}{|l|l|}
\hline \multicolumn{1}{|c|}{ Chapter IV, LLW Requirements } & Facility Compliance Information \\
\hline $\begin{array}{l}\text { assessment and composite analysis and a determination } \\
\text { of the need to revise the performance assessment or } \\
\text { composite analysis. }\end{array}$ & \\
\hline
\end{tabular}

(5) Disposal Authorization. A disposal authorization $\quad$ See P. above.

statement shall be obtained prior to construction of a new

low-level waste disposal facility. Field Elements with

existing low-level waste disposal facilities shall obtain a disposal authorization statement in accordance with the schedule in the Complex-Wide Low-Level Waste Management Program Plan. The disposal authorization statement shall be issued based on a review of the facility's performance assessment, composite analysis, performance assessment and composite analysis maintenance, preliminary closure plan, and preliminary monitoring plan. The disposal authorization statement shall specify the limits and conditions on construction, design, operations, and closure of the low-level waste facility based on these reviews. A disposal authorization statement is a part of the radioactive waste management basis for a disposal facility. Failure to obtain a disposal authorization statement by the implementation date of this Order shall result in shutdown of the disposal facility.

(6) Disposal Facility Operations. The disposal facility $\quad$ See P. above. design and operation must be consistent with the disposal facility closure plan and lead to disposal facility closure that provides a reasonable expectation that performance objectives will be met. Low-level waste shall be disposed in such a manner that achieves the performance objectives stated in this Chapter, consistent with the disposal facility radiological performance assessment. Additional requirements include:

(a) Operating procedures shall be developed and implemented for low-level waste disposal facilities that protect the public, workers, and the environment; ensure the security of the facility; minimize subsidence during and after waste emplacement; achieve long-term stability and minimize the need for long-term active maintenance; and meet the requirements of the closure/post-closure plan.

(b) Permanent identification markers for disposal excavations and monitoring wells shall be emplaced.

(c) Low-level waste placement into disposal units shall minimize voids between waste containers. Voids within disposal units shall be filled to the extent practical. Uncontainerized bulk waste shall also be placed in a manner that minimizes voids and subsidence.

(d) Operations are to be conducted so that active waste

See P. above.

See P. above.

See P. above.

See P. above. 
Table 2. (continued).

Facility Name: TRA-605 Radioactive Materials Storage Area

\begin{tabular}{|l|}
\hline \multicolumn{1}{|c|}{ Chapter IV, LLW Requirements } \\
\hline $\begin{array}{l}\text { disposal operations will not have an adverse effect on } \\
\text { any other disposal units. }\end{array}$ \\
\hline $\begin{array}{l}\text { (e) Operations shall include a process for tracking and } \\
\text { documenting low-level waste placement in the facility by } \\
\text { generator source. }\end{array}$ \\
(7) Alternate Requirements for Low-Level Waste \\
Disposal Facility Design and Operation. Requirements \\
other than those set forth in this Section for the design \\
and operation of a low-level waste disposal facility may \\
be approved on a specific basis if a reasonable \\
expectation is demonstrated that the disposal \\
performance objectives will be met.
\end{tabular}

Q. Closure. The following requirements are in addition to NA; LLW is not disposed of in this facility. those in Chapter I of this Manual.

(1) Disposal Facility Closure Plans. A preliminary closure plan shall be developed and submitted to Headquarters for review with the performance assessment and composite analysis. The closure plan shall be updated following issuance of the disposal authorization statement to incorporate conditions specified in the disposal authorization statement. Closure plans shall:

(a) Be updated as required during the operational life of the facility.

(b) Include a description of how the disposal facility will See Q. above. be closed to achieve long-term stability and minimize the need for active maintenance following closure and to ensure compliance with the requirements of DOE 5400.5, Radiation Protection of the Public and the Environment.

(c) Include the total expected inventory of wastes to be disposed of at the facility over the operational life of the facility.

(2) Disposal Facility Closure. Closure of a disposal facility shall occur within a five-year period after it is filled to capacity, or after the facility is otherwise determined to be no longer needed.

(a) Prior to facility closure, the final inventory of the low-level waste disposed in the facility shall be prepared and incorporated in the performance assessment and composite analysis which shall be updated to support the closure of the facility.

(b) A final closure plan shall be prepared based on the final inventory of waste disposed in the facility, the plan implemented, and the updated performance assessment and composite analysis prepared in support of the facility

See P. above.

See P. above.

See Q. above.

See Q. above.

See Q. above.

See Q. above.

See Q. above. acility Compliance Information

See Q. above.

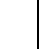


Table 2. (continued).

\begin{tabular}{|c|c|}
\hline \multicolumn{2}{|c|}{ Facility Name: TRA-605 Radioactive Materials Storage Area } \\
\hline Chapter IV, LLW Requirements & Facility Compliance Information \\
\hline closure. & \\
\hline $\begin{array}{l}\text { (c) Institutional control measures shall be integrated into } \\
\text { land use and stewardship plans and programs, and shall } \\
\text { continue until the facility can be released pursuant to } \\
\text { DOE 5400.5, Radiation Protection of the Public and the } \\
\text { Environment. }\end{array}$ & See Q. above. \\
\hline $\begin{array}{l}\text { (d) The location and use of the facility shall be filed with } \\
\text { the local authorities responsible for land use and zoning. }\end{array}$ & See Q. above. \\
\hline $\begin{array}{l}\text { R. Monitoring. The following requirements are in } \\
\text { addition to those in Chapter I of this Manual [DOE M } \\
435.1-1 \text { \&I.1.E(7)]. }\end{array}$ & See (1), (2), and (3) below. \\
\hline $\begin{array}{l}\text { (1) All Waste Facilities. Parameters that shall be sampled } \\
\text { or monitored, at a minimum, include: temperature, } \\
\text { pressure (for closed systems), radioactivity in ventilation } \\
\text { exhaust and liquid effluent streams, and flammable or } \\
\text { explosive mixtures of gases. Facility monitoring } \\
\text { programs shall include verification that passive and } \\
\text { active control systems have not failed. }\end{array}$ & $\begin{array}{l}\text { Monitoring requirements at INL radioactive waste } \\
\text { management facilities are tailored for the specific } \\
\text { facility to enable timely indication of developing } \\
\text { problems. Existing radiological control procedures and } \\
\text { assessments are followed/completed to monitor waste } \\
\text { facilities. }\end{array}$ \\
\hline $\begin{array}{l}\text { From DOE G 435.1-1 Chapter IV: The minimum } \\
\text { parameters specified in the requirement were selected } \\
\text { based on their potential significance for anticipating and } \\
\text { identifying undesirable conditions at low-level waste } \\
\text { management facilities. Each facility's radioactive waste } \\
\text { management basis should include an evaluation of the } \\
\text { applicability and significance of the minimum } \\
\text { parameters. This evaluation also needs to consider } \\
\text { additional parameters to be sampled or monitored to } \\
\text { ensure the protection of the public health, the } \\
\text { environment, and the workers. If a minimum parameter } \\
\text { specified in the requirement is deemed to be not } \\
\text { applicable in any way to the active operation of that } \\
\text { facility, then that justification should be included in the } \\
\text { radioactive waste management basis and when approved } \\
\text { constitutes an exemption to the manual. }\end{array}$ & $\begin{array}{l}\text { frequency of radiological control surveys of all } \\
\text { radiological areas. MCP-139 specifies the use of } \\
\text { Form } 441 . \text { A34. This form is referred to as the "routine } \\
\text { sheet" and is to be used by facility radiological control } \\
\text { foremen to list radiological areas that are to be surveyed, } \\
\text { the survey periods, and methods. }\end{array}$ \\
\hline $\begin{array}{l}\text { Verification activities are part of the radioactive waste } \\
\text { management basis as a condition for operation and } \\
\text { documented appropriately. }\end{array}$ & \\
\hline $\begin{array}{l}\text { Compliance with this requirement is demonstrated if } \\
\text { monitoring or sampling for the stated parameters is } \\
\text { performed for all facilities with a precision, accuracy, } \\
\text { and frequency consistent with timely identification of } \\
\text { developing problems and a justification exists in the } \\
\text { approved radioactive waste management basis for those } \\
\text { specified parameters which are not monitored or } \\
\text { sampled. }\end{array}$ & \\
\hline $\begin{array}{l}\text { (2) Liquid Waste Storage Facilities. For facilities storing } \\
\text { liquid low-level waste, the following shall also be } \\
\text { monitored: liquid level and/or waste volume, and }\end{array}$ & NA; liquid waste is not stored at this facility. \\
\hline
\end{tabular}


Table 2. (continued).

\begin{tabular}{|l|l|}
\hline \multicolumn{2}{|c|}{ Facility Name: TRA-605 Radioactive Materials Storage Area } \\
\hline \multicolumn{1}{|c|}{ Chapter IV, LLW Requirements } & \multicolumn{1}{|c|}{ Facility Compliance Information } \\
\hline significant waste chemistry parameters. & \\
\hline $\begin{array}{l}\text { (3) Disposal Facilities. A preliminary monitoring plan for } \\
\text { a low-level waste disposal facility shall be prepared and } \\
\text { submitted to Headquarters for review with the } \\
\text { performance assessment and composite analysis. The } \\
\text { monitoring plan shall be updated within one year } \\
\text { following issuance of the disposal authorization } \\
\text { statement to incorporate and implement conditions } \\
\text { specified in the disposal authorization statement. }\end{array}$ & \\
$\begin{array}{l}\text { (a) The site-specific performance assessment and } \\
\text { composite analysis shall be used to determine the media, } \\
\text { locations, radionuclides, and other substances to be } \\
\text { monitored. }\end{array}$ & See (3) above. \\
\hline $\begin{array}{l}\text { (b) The environmental monitoring program shall be } \\
\text { designed to include measuring and evaluating releases, } \\
\text { migration of radionuclides, disposal unit subsidence, and } \\
\text { changes in disposal facility and disposal site parameters } \\
\text { which may affect long-term performance. }\end{array}$ & See (3) above. \\
\hline $\begin{array}{l}\text { (c) The environmental monitoring programs shall be } \\
\text { capable of detecting changing trends in performance to } \\
\text { allow application of any necessary corrective action prior } \\
\text { to exceeding the performance objectives in this Chapter. }\end{array}$ & See (3) above. \\
\hline
\end{tabular}

\subsection{TRA-617 Radioactive Materials Storage Area}

1. Facility description: The TRA-617 Radioactive Materials Storage Area is an outside storage area approximately $24 \times 24 \mathrm{~m}$. The area is part of a support building initially constructed during construction of ATR. The building structure has been removed and the concrete pad remains. The portion of the pad used for low-level radioactive material storage is cordoned off from the rest of the area in accordance with radiological control procedures. WGS is the Radioactive Materials Storage Area Custodian (IAG-443) for this facility.

2. Hazard category: LTHC3 (radiological)

3. Radioactive waste managed at this facility: Routine contact-handled LLW (solid) is stored at this facility. TSCA-regulated LLW may be stored at this facility.

\section{RWMB documents/programs:}

a) Safety basis/hazard analysis:

- HAD-277, "Reactor Technology Complex Radioactive Materials Storage Areas (TRA-617 and the Fenced Area East of TRA-605)"

- SD-24.1.3, "ATR Complex Facilities and Site Services Safety Basis Administrative Controls"

b) Laboratory-wide:

- Form 435.A01, "Radioactive Waste Container Inspection Checklist"

- Form 441.A34, "INL Radiological Control Required Surveys"

- LI-435, "Waste Management Routine Field Activities" 
- LRD-15001, "Radiological Control Manual"

- LWP-13840, "Management of Issues, Observations, and Noteworthy Practices"

- LWP-14002, "Timeout and Stop Work Authority"

- LWP-15011, "Radioactive Material Areas and Radioactive Storage Areas"

- MCP-139, "Radiological Surveys"

- MCP-17000, "Waste Generator Services Waste Management"

- MCP-17410, "Management of Waste Storage Areas"

- MCP-17500, "Waste Generator Services Certification of Waste Shipments to the Nevada Test Site"

- PLN-114, "INL Emergency Plan/RCRA Contingency Plan"

- PLN-522, "Quality Assurance Program Plan for the Waste Management/Waste Certification Program"

c) Facility-specific:

- IAG-443, “Tenant Use Agreement Between Facility Management Services, Laboratory Support Complex at the Advanced Test Reactor Complex and Waste Generator Services/Energy Solutions in Materials Storage Areas TRA-617 And Fenced Area East of TRA-605."

Table 3 presents the facility compliance information for Chapter IV, "Low-level Waste Requirements."

Table 3. TRA-617 Radioactive Materials Storage Area DOE Manual 435.1-1 low-level waste requirements and facility compliance information.

\begin{tabular}{|l|l|}
\hline \multicolumn{2}{|c|}{ Facility Name: TRA-617 Radioactive Materials Storage Area } \\
\hline \multicolumn{1}{|c|}{ Chapter IV, LLW Requirements } & \multicolumn{1}{|c|}{ Facility Compliance Information } \\
\hline $\begin{array}{l}\text { A. Definition of Low-Level Waste. Low-level radioactive } \\
\text { waste is radioactive waste that is not high-level radioactive } \\
\text { waste, spent nuclear fuel, transuranic waste, byproduct } \\
\text { material (as defined in section 11e.(2) of the Atomic } \\
\text { Energy Act of 1954, as amended), or naturally occurring } \\
\text { radioactive material. }\end{array}$ & $\begin{array}{l}\text { Thich DOE radioactive waste is to be managed as } \\
\text { Chapter IV. }\end{array}$ \\
$\begin{array}{l}\text { (From DOE G 435.1-1 Chapter IV: Low-level radioactive } \\
\text { waste is defined by what it is not. The guidance on } \\
\text { definitions in Chapters II and III should be consulted first } \\
\text { for making a determination on how to properly manage a } \\
\text { suspect waste stream.) }\end{array}$ & $\begin{array}{l}\text { requirements of this chapter is not managed under the } \\
\text { requirements of DOE Manual 435.1-1 Chapter II or }\end{array}$ \\
\hline $\begin{array}{l}\text { B. Management of Specific Wastes. The following provide } \\
\text { for management of specific wastes as low-level waste in } \\
\text { accordance with the requirements in this Chapter: }\end{array}$ & See below. \\
\hline $\begin{array}{l}\text { (1) Mixed Low-Level Waste. Low-level waste determined } \\
\text { to contain both source, special nuclear, or byproduct } \\
\text { material subject to the Atomic Energy Act of 1954, as } \\
\text { amended, and a hazardous component subject to the } \\
\text { Resource Conservation and Recovery Act (RCRA), as } \\
\text { amended, shall be managed in accordance with the } \\
\text { requirements of RCRA and DOE O 435.1, Radioactive } \\
\text { Waste Management, and this Manual. }\end{array}$ & \\
\hline
\end{tabular}


Table 3. (continued).

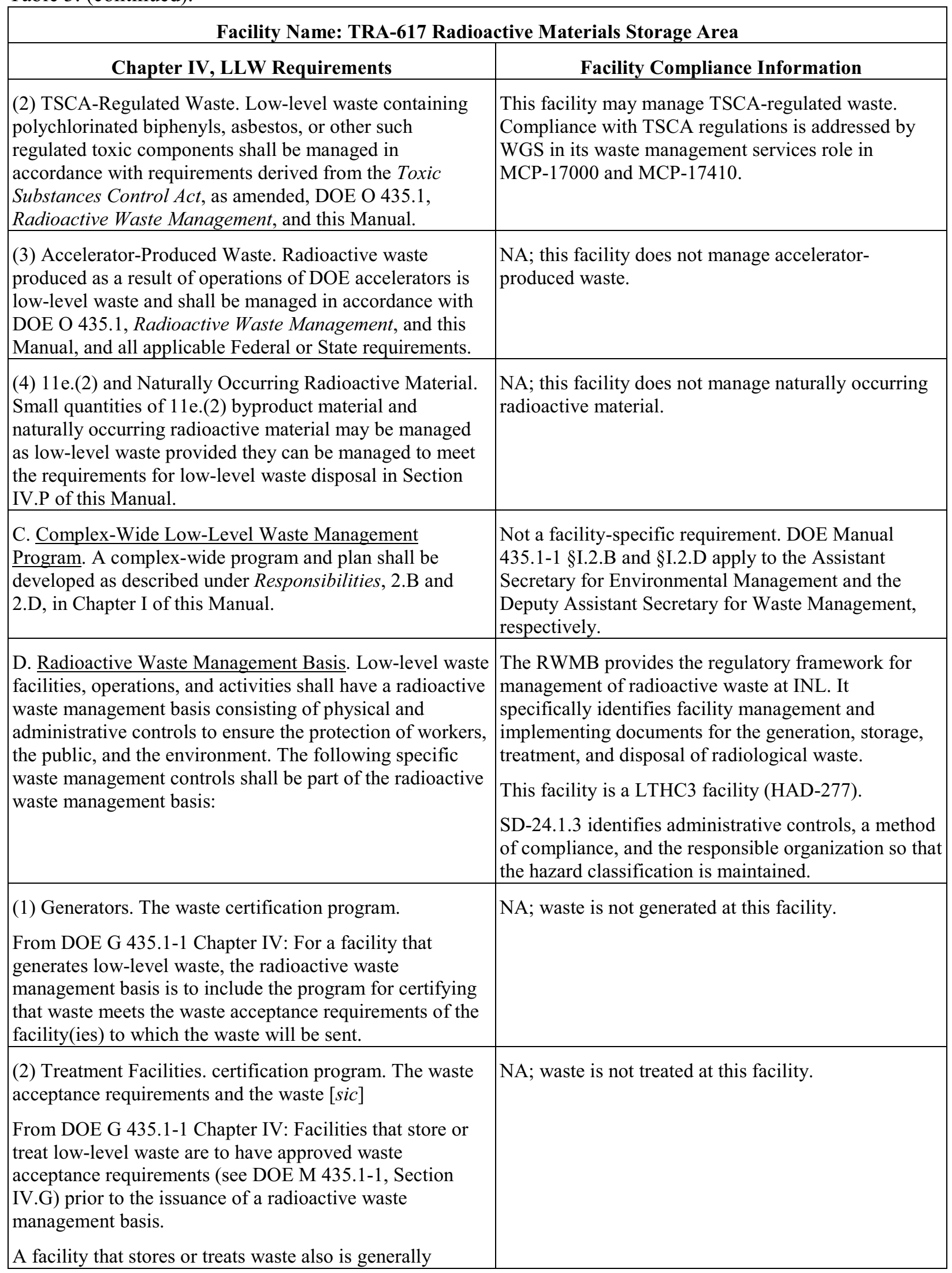


Table 3. (continued).

Facility Name: TRA-617 Radioactive Materials Storage Area

\begin{tabular}{l} 
Chapter IV, LLW Requirements \\
\hline \multicolumn{1}{|c|}{ expected to have a waste certification program. Waste from } \\
these facilities will have to be certified as meeting the \\
waste acceptance requirements of the facility to which it \\
will be transferred, and the facilities have the potential for \\
generating radioactive waste (e.g., secondary processing \\
streams from treatment, monitoring and sampling, \\
radioactive release cleanup). Consequently, storage and \\
treatment facilities should also have an approved waste \\
certification program as part of their radioactive waste \\
management basis. \\
As part of the radioactive waste management basis, site \\
personnel needs to implement a system or process for \\
tracking the waste inventory at a storage, treatment, or \\
disposal facility.
\end{tabular}

(3) Storage Facilities. The waste acceptance requirements and the waste certification program.

From DOE G 435.1-1 Chapter IV: Facilities that store or treat low-level waste are to have approved waste acceptance requirements (see DOE M 435.1-1, Section IV.G) prior to the issuance of a radioactive waste management basis.

A facility that stores or treats waste also is generally expected to have a waste certification program. Waste from these facilities will have to be certified as meeting the waste acceptance requirements of the facility to which it will be transferred, and the facilities have the potential for generating radioactive waste (e.g., secondary processing streams from treatment, monitoring and sampling, radioactive release cleanup). Consequently, storage and treatment facilities should also have an approved waste certification program as part of their radioactive waste management basis.

As part of the radioactive waste management basis, site personnel needs to implement a system or process for tracking the waste inventory at a storage, treatment, or disposal facility.

(4) Disposal Facilities. The performance assessment, composite analysis, disposal authorization statement, closure plan, waste acceptance requirements, and monitoring plan.

E. Contingency Actions. The following requirements are in addition to those in Chapter I of this Manual [DOE M 435.1-1 §I.1.E(5)].

(1) Contingency Storage. For off-normal or emergency situations involving high activity or high hazard liquid low-level waste storage or treatment, spare capacity with

See G. and J. below for waste acceptance and waste certification program requirements.

HAD-277 establishes the facility as a LTHC3 facility and requires the facility manager to implement a method of tracking and controlling the radioactive material inventory so that the sum-of-the-ratios does not exceed 1 .

SD-24.1.3, Appendix B addresses the use of IWTS to track the radionuclide quantity limits and the establishment of an alarm/warning limit in IWTS.

MCP-17000 $\$ 4$ specifies the use of IWTS, which tracks the waste inventory.

NA; this facility is not a disposal facility.

Not a facility-specific requirement. DOE

Manual 435.1-1 §I.1.E(5) addresses the site-wide emergency management system. The INL plan is provided in PLN-114.

NA; this facility does not store or treat liquid waste in tanks. 
Table 3. (continued).

\begin{tabular}{|c|c|}
\hline \multicolumn{2}{|c|}{ Facility Name: TRA-617 Radioactive Materials Storage Area } \\
\hline Chapter IV, LLW Requirements & Facility Compliance Information \\
\hline $\begin{array}{l}\text { adequate capabilities shall be maintained to receive the } \\
\text { largest volume of liquid contained in any one storage tank } \\
\text { or treatment facility. Tanks or other facilities that are } \\
\text { designated low-level waste contingency storage shall be } \\
\text { maintained in an operational condition when waste is } \\
\text { present and shall meet the requirements of DOE O 435.1, } \\
\text { Radioactive Waste Management, and this Manual. }\end{array}$ & \\
\hline $\begin{array}{l}\text { From DOE G 435.1-1 Chapter IV: Compliance with these } \\
\text { requirements is demonstrated if adequate spare capacity } \\
\text { and transfer equipment exists for emergency transfers of all } \\
\text { high activity and high hazard liquid low-level waste. In } \\
\text { addition, the capability to perform emergency transfers is } \\
\text { demonstrated by having waste transfer routings identified, } \\
\text { operational procedures to direct transfers, staff trained to } \\
\text { the procedures, and records showing that the spare capacity } \\
\text { and transfer capability are kept in operating condition. }\end{array}$ & \\
\hline $\begin{array}{l}\text { (2) Transfer Equipment. Pipelines and auxiliary facilities } \\
\text { necessary for the transfer of high activity or high hazard } \\
\text { liquid low-level waste to contingency storage shall be } \\
\text { maintained in an operational condition when waste is } \\
\text { present and shall meet the requirements of DOE O 435.1, } \\
\text { Radioactive Waste Management, and this Manual. }\end{array}$ & $\begin{array}{l}\text { NA; this facility does not store or treat liquid waste in } \\
\text { tanks. }\end{array}$ \\
\hline $\begin{array}{l}\text { From DOE G 435.1-1 Chapter IV: Compliance with these } \\
\text { requirements is demonstrated if adequate spare capacity } \\
\text { and transfer equipment exists for emergency transfers of all } \\
\text { high activity and high hazard liquid low-level waste. In } \\
\text { addition, the capability to perform emergency transfers is } \\
\text { demonstrated by having waste transfer routings identified, } \\
\text { operational procedures to direct transfers, staff trained to } \\
\text { the procedures, and records showing that the spare capacity } \\
\text { and transfer capability are kept in operating condition. }\end{array}$ & \\
\hline \multirow{4}{*}{$\begin{array}{l}\text { F. Corrective Actions. I of this Manual. The following } \\
\text { requirements are in addition to those in Chapter [sic] } \\
\text { From DOE G 435.1-1 Chapter IV: Compliance with DOE } \\
\text { M 435.1-1 §I.2.G.(1) is demonstrated by records showing } \\
\text { what corrective actions were taken to remedy situations in } \\
\text { the radioactive waste management system. } \\
\text { Compliance with DOE M 435.1-1 §I.2.G.(2) is } \\
\text { demonstrated by having the necessary procedures, } \\
\text { mechanisms, and training in place to effect shutdown or } \\
\text { curtailment of activities which pose an imminent danger or } \\
\text { other serious hazard to workers or the public, or are not } \\
\text { protective of the environment. }\end{array}$} & $\begin{array}{l}\text { The INL-wide procedure addressing problem } \\
\text { identification as required by DOE Manual 435.1-1 }\end{array}$ \\
\hline & \\
\hline & $\begin{array}{l}\text { The INL-wide procedure addressing shutdown or } \\
\text { curtailment of activities as required by DOE }\end{array}$ \\
\hline & Manual 435.1-1 §I.2.G.(2) is LWP-14002. \\
\hline $\begin{array}{l}\text { (1) Order Compliance. Corrective actions shall be } \\
\text { implemented whenever necessary to ensure the } \\
\text { requirements of DOE O } 435.1 \text {, Radioactive Waste } \\
\text { Management, and this Manual are met. }\end{array}$ & See F. above. \\
\hline
\end{tabular}


Table 3. (continued).

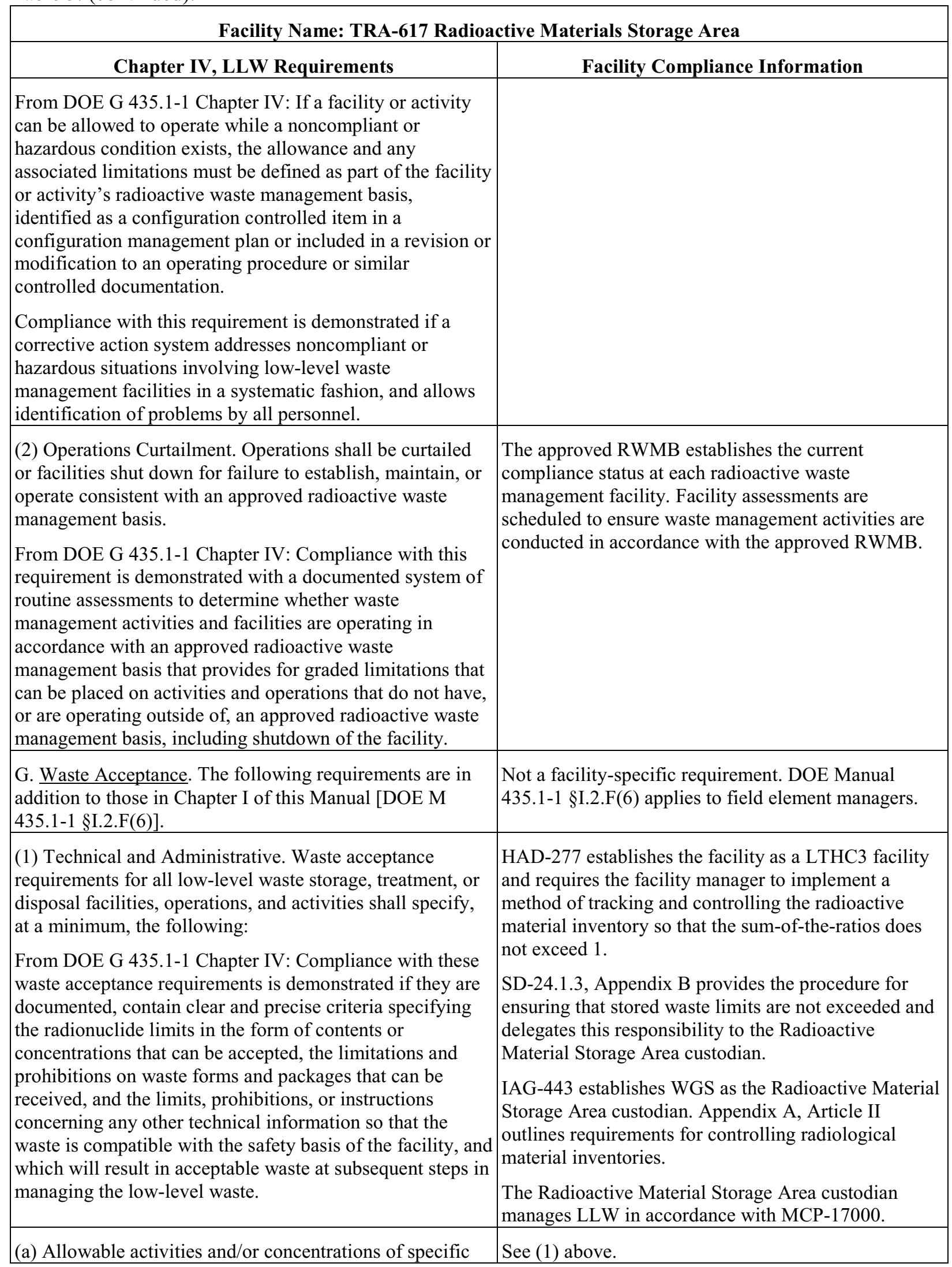


Table 3. (continued).

\begin{tabular}{|c|c|}
\hline \multicolumn{2}{|c|}{ Facility Name: TRA-617 Radioactive Materials Storage Area } \\
\hline Chapter IV, LLW Requirements & Facility Compliance Information \\
\hline radionuclides. & \\
\hline $\begin{array}{l}\text { (b) Acceptable waste form and/or container requirements } \\
\text { that ensure the chemical and physical stability of waste } \\
\text { under conditions that might be encountered during } \\
\text { transportation, storage, treatment, or disposal. }\end{array}$ & See (1) above. \\
\hline $\begin{array}{l}\text { (c) Restrictions or prohibitions on waste, materials, or } \\
\text { containers that may adversely affect waste handlers or } \\
\text { compromise facility or waste container performance. }\end{array}$ & See (1) above. \\
\hline $\begin{array}{l}\text { (d) The following are additional waste acceptance } \\
\text { requirements that shall be specified in low-level waste } \\
\text { disposal facility waste acceptance requirements: }\end{array}$ & NA; this facility is not a LLW disposal facility. \\
\hline $\begin{array}{l}1 \text { Low-level waste must contribute to and not detract from } \\
\text { achieving long-term stability of the facility, minimizing the } \\
\text { need for long-term active maintenance, minimizing } \\
\text { subsidence, and minimizing contact of water with waste. } \\
\text { Void spaces within the waste and, if containers are used, } \\
\text { between the waste and its container shall be reduced to the } \\
\text { extent practical. }\end{array}$ & See (d) above. \\
\hline $\begin{array}{l}2 \text { Liquid low-level waste or low-level waste containing } \\
\text { free liquid must be converted into a form that contains as } \\
\text { little freestanding liquid as is reasonably achievable, but in } \\
\text { no case shall the liquid exceed } 1 \text { percent of the waste } \\
\text { volume when the low-level waste is in a disposal container, } \\
\text { or } 0.5 \text { percent of the waste volume after it is processed to a } \\
\text { stable form. }\end{array}$ & See (d) above. \\
\hline $\begin{array}{l}3 \text { Low-level waste must not be readily capable of } \\
\text { detonation or of explosive decomposition or reaction at } \\
\text { anticipated pressures and temperatures, or of explosive } \\
\text { reaction with water. Pyrophoric materials contained in } \\
\text { waste shall be treated, prepared, and packaged to be } \\
\text { nonflammable. }\end{array}$ & See (d) above. \\
\hline $\begin{array}{l}4 \text { Low-level waste must not contain, or be capable of } \\
\text { generating by radiolysis or biodegradation, quantities of } \\
\text { toxic gases, vapors, or fumes harmful to the public or } \\
\text { workers or disposal facility personnel, or harmful to the } \\
\text { long-term structural stability of the disposal site. }\end{array}$ & See (d) above. \\
\hline $\begin{array}{l}5 \text { Low-level waste in a gaseous form must be packaged } \\
\text { such that the pressure does not exceed } 1.5 \text { atmospheres } \\
\text { absolute at } 20 \text { C. }[\text { sic }]\end{array}$ & See (d) above. \\
\hline $\begin{array}{l}\text { (e) The basis, procedures, and levels of authority required } \\
\text { for granting exceptions to the waste acceptance } \\
\text { requirements, which shall be contained in each facility's } \\
\text { waste acceptance documentation. Each exception request } \\
\text { shall be documented, including its disposition as approved } \\
\text { or not approved. } \\
\text { From DOE G 435.1-1 Chapter IV: Waste acceptance }\end{array}$ & $\begin{array}{l}\text { Exceptions to the radioactive material inventory limits } \\
\text { are not permitted. }\end{array}$ \\
\hline
\end{tabular}


Table 3. (continued).

Facility Name: TRA-617 Radioactive Materials Storage Area

\begin{tabular}{l} 
Chapter IV, LLW Requirements \\
\hline requirements are acceptable if they are documented and \\
contain a clear description of the procedure and bases for \\
obtaining an exception or deviation to the acceptance \\
criteria for low-level waste to be received at the facility.
\end{tabular}

(2) Evaluation and Acceptance. The receiving facility shall evaluate waste for acceptance, including confirmation that the technical and administrative requirements have been met. A process for the disposition of non-conforming wastes shall be established.

From DOE G 435.1-1 Chapter IV: Compliance with the waste acceptance requirements for a low-level waste management facility is demonstrated if they include a process for evaluation and acceptance of incoming waste to ensure the acceptance criteria of the facility receiving the waste are met that includes one of or a combination of: (1) testing, sampling, and analysis of representative samples of waste upon receipt; (2) testing, sampling, and analysis of split samples of waste taken at the generator site; (3) evaluation of testing, sampling, and analysis of data provided by the generator, or (4) audits, reviews, surveillance, or observations of generator waste certification programs and characterization activities. Additionally, acceptable waste acceptance requirements for a storage, treatment or disposal facility will have documented procedures and actions to be taken if a waste that does not conform to the waste acceptance criteria is received at the facility.

H. Waste Generation Planning. The following requirements are in addition to those in Chapter I of this Manual [DOE M 435.1-1 §I.2.F(7)].

(1) Life-Cycle Planning. Prior to waste generation, planning shall be performed to address the entire life cycle for all low-level waste streams.

From DOE G 435.1-1 Chapter IV: Compliance with this planning requirement is demonstrated by the individual sites establishing a process for evaluating the life-cycle of low-level waste prior to its generation, including the identification of low-level wastes with no path to disposal and appropriate records justifying the newly generated low-level waste stream(s), and site personnel possessing planning information showing the location(s) where lowlevel waste will be stored, treated, and/or disposed along with a confirmation that the personnel managing the facilities agree that the low-level waste may be managed at those facilities.

(2) Waste with No Identified Path to Disposal. Low-level waste streams with no identified path to disposal shall be generated only in accordance with approved conditions
SD-24.1.3, Appendix B addresses the use of IWTS to track the radionuclide quantity limits and the establishment of an alarm/warning limit in IWTS.

Nonconforming waste is not permitted.
Not a facility-specific requirement. DOE

Manual 435.1-1 §I.2.F(7) applies to field element managers.

NA; LLW is not generated at this facility.

NA; LLW is not generated at this facility. 
Table 3. (continued).

\begin{tabular}{|c|c|}
\hline \multicolumn{2}{|c|}{ Facility Name: TRA-617 Radioactive Materials Storage Area } \\
\hline Chapter IV, LLW Requirements & Facility Compliance Information \\
\hline \multicolumn{2}{|l|}{ which, at a minimum, shall address: } \\
\hline (a) Programmatic need to generate the waste; & See (2) above. \\
\hline $\begin{array}{l}\text { (b) Characteristics and issues preventing the disposal of the } \\
\text { waste; }\end{array}$ & See (2) above. \\
\hline $\begin{array}{l}\text { (c) Safe storage of the waste until disposal can be } \\
\text { achieved; and }\end{array}$ & See (2) above. \\
\hline $\begin{array}{l}\text { (d) Activities and plans for achieving final disposal of the } \\
\text { waste. }\end{array}$ & See (2) above. \\
\hline \multirow{4}{*}{$\begin{array}{l}\text { I. Waste Characterization. Low-level waste shall be } \\
\text { characterized using direct or indirect methods, and the } \\
\text { characterization documented in sufficient detail to ensure } \\
\text { safe management and compliance with the waste } \\
\text { acceptance requirements of the facility receiving the waste. } \\
\text { From DOE G 435.1-1 Chapter IV: Compliance with this } \\
\text { requirement is demonstrated by a program for documenting } \\
\text { and the existence of records that document the process for } \\
\text { acquiring and verifying the validity of low-level waste } \\
\text { characterization data acquired through the use of direct or } \\
\text { indirect methods. }\end{array}$} & $\begin{array}{l}\text { IAG-443 establishes WGS as the Radioactive Material } \\
\text { Storage Area custodian. }\end{array}$ \\
\hline & $\begin{array}{l}\text { IAG-443, Appendix B, establishes WGS' functional } \\
\text { responsibilities for waste, which are to arrange for the } \\
\text { removal and disposition of waste generated and }\end{array}$ \\
\hline & characterized by others. \\
\hline & MCP-17000 addresses waste characterization. \\
\hline $\begin{array}{l}\text { (1) Data Quality Objectives. The data quality objectives } \\
\text { process, or a comparable process, shall be used for } \\
\text { identifying characterization parameters and acceptable } \\
\text { uncertainty in characterization data. }\end{array}$ & \multirow{2}{*}{$\begin{array}{l}\text { Radioactive waste management facilities characterize } \\
\text { waste in accordance with the requirements of the } \\
\text { receiving storage, treatment, or disposal facility. The } \\
\text { documented use of a data quality objectives process, } \\
\text { or comparable process, was not identified for this } \\
\text { facility. }\end{array}$} \\
\hline $\begin{array}{l}\text { From DOE G } 435.1-1 \text { Chapter IV: Compliance with this } \\
\text { requirement is demonstrated by the documented use of a } \\
\text { data quality objectives or a comparable process for } \\
\text { determining the type, quantity, and quality of } \\
\text { characterization data needed to safely manage low-level } \\
\text { waste. }\end{array}$ & \\
\hline $\begin{array}{l}\text { (2) Minimum Waste Characterization. Characterization } \\
\text { data shall, at a minimum, include the following } \\
\text { information relevant to the management of the waste: }\end{array}$ & \multirow{2}{*}{$\begin{array}{l}\text { MCP-17000 } \S \S 4.2,4.3 \text {, and } 4.4 \text { provide waste } \\
\text { characterization requirements. Information on } \\
\text { absorbent media is required in } \S \S 4.5 \text { and } 4.7 \text {. } \\
\text { MCP- } 17000 \text { also specifies the use of IWTS, which } \\
\text { documents characterization data in an IWTS profile. }\end{array}$} \\
\hline $\begin{array}{l}\text { From DOE G 435.1-1 Chapter IV: Compliance with this } \\
\text { requirement is demonstrated by the existence of a program } \\
\text { or procedure for determining and records that document } \\
\text { characterization of low-level waste consistent with the } \\
\text { minimum characterization data requirements. }\end{array}$ & \\
\hline (a) Physical and chemical characteristics; & See (2) above. \\
\hline $\begin{array}{l}\text { (b) Volume, including the waste and any stabilization or } \\
\text { absorbent media; }\end{array}$ & See (2) above. \\
\hline (c) Weight of the container and contents; & See (2) above. \\
\hline $\begin{array}{l}\text { (d) Identities, activities, and concentrations of major } \\
\text { radionuclides; }\end{array}$ & See (2) above. \\
\hline
\end{tabular}


Table 3. (continued).

\begin{tabular}{|c|c|}
\hline \multicolumn{2}{|c|}{ Facility Name: TRA-617 Radioactive Materials Storage Area } \\
\hline Chapter IV, LLW Requirements & Facility Compliance Information \\
\hline (e) Characterization date; & See (2) above. \\
\hline (f) Generating source; and & See (2) above. \\
\hline $\begin{array}{l}\text { (g) Any other information which may be needed to prepare } \\
\text { and maintain the disposal facility performance assessment, } \\
\text { or demonstrate compliance with applicable performance } \\
\text { objectives. }\end{array}$ & See (2) above. \\
\hline $\begin{array}{l}\text { J. Waste Certification. A waste certification program shall } \\
\text { be developed, documented, and implemented to ensure that } \\
\text { the waste acceptance requirements of facilities receiving } \\
\text { low-level waste for storage, treatment, and disposal are } \\
\text { met. } \\
\text { From DOE G 435.1-1 Chapter IV: Compliance with the } \\
\text { development and documentation portion of the certification } \\
\text { requirement is demonstrated by a waste certification plan } \\
\text { that identifies the organizations involved, assigns } \\
\text { responsibilities for implementing the program, and } \\
\text { describes or references the quality assurance, training, } \\
\text { procurement controls, records management, and } \\
\text { procedures to be used by the program. Acceptable } \\
\text { performance for implementing the program is } \\
\text { demonstrated when appropriate personnel are trained and } \\
\text { follow the procedures that govern their part of the waste } \\
\text { certification. Additionally, acceptable performance is } \\
\text { demonstrated if the waste certification plan and procedures } \\
\text { are current and controlled in accordance with a document } \\
\text { controls program, and records related to certification (e.g., } \\
\text { certification statements, training records, procurement } \\
\text { records, characterization records, container records) are } \\
\text { generated and managed in accordance with the established } \\
\text { site program. }\end{array}$ & $\begin{array}{l}\text { MCP-17000 cites a waste certification program for } \\
\text { LLW destined for NNSS. For waste destined for } \\
\text { locations other than NNSS, the waste disposition } \\
\text { specialist is responsible for certifying the waste stream } \\
\text { by ensuring the waste, as characterized, falls within } \\
\text { the limitations of the waste acceptance criteria of the } \\
\text { treatment, storage, or disposal facility (§2). } \\
\text { Container procurement is addressed in MCP-17000 } \\
\text { \$4.6. } \\
\text { MCP-17500 provides the WGS waste certification } \\
\text { program for LLW to be shipped to NNSS. } \\
\text { Waste certification is performed and tracked using } \\
\text { IWTS. Documentation of the IWTS Program is } \\
\text { available electronically only. } \\
\text { PLN-522 requires waste technical specialists and } \\
\text { waste disposition specialists to complete the } \\
\text { appropriate training/qualification before being granted } \\
\text { approval authority for profiles within the IWTS } \\
\text { Program. The waste certification official, alternate } \\
\text { waste certification official, and NNSS packaging } \\
\text { certifiers must complete the appropriate } \\
\text { training/qualifications to disposition waste to NNSS. }\end{array}$ \\
\hline $\begin{array}{l}\text { (1) Certification Program. The waste certification program } \\
\text { shall designate the officials who have the authority to } \\
\text { certify and release waste for shipment; and specify what } \\
\text { documentation is required for waste generation, } \\
\text { characterization, shipment, and certification. The program } \\
\text { shall provide requirements for auditability, retrievability, } \\
\text { and storage of required documentation and specify the } \\
\text { records retention period. }\end{array}$ & $\begin{array}{l}\text { See J. above. MCP-17500 } \S \S 2 \text { and } 5 \text { address } \\
\text { certification records for shipments to NNSS. }\end{array}$ \\
\hline $\begin{array}{l}\text { From DOE G } 435.1-1 \text { Chapter IV: Compliance with this } \\
\text { requirement is demonstrated by a program or procedure for } \\
\text { record keeping and records showing that low-level waste is } \\
\text { certified as having met the waste acceptance criteria of the } \\
\text { facility to which it was transferred and that the certification } \\
\text { statement is supported by additional records regarding the } \\
\text { waste source, characterization, and container. }\end{array}$ & \\
\hline $\begin{array}{l}\text { (2) Certification before Transfer. Low-level waste shall be } \\
\text { certified as meeting waste acceptance requirements before }\end{array}$ & $\begin{array}{l}\text { See J. above. MCP-17500 } \S 4.3 .6 \text { addresses controls } \\
\text { for certification before transfer for LLW to be }\end{array}$ \\
\hline
\end{tabular}


Table 3. (continued).

Facility Name: TRA-617 Radioactive Materials Storage Area

\begin{tabular}{l} 
Chapter IV, LLW Requirements \\
\hline \multicolumn{1}{|c|}{ it is transferred to the facility receiving the waste. } \\
From DOE G 435.1-1 Chapter IV: Compliance with this \\
requirement is demonstrated by the presence of a \\
certification program which includes procedures requiring \\
a signed certification statement prior to the release of waste \\
for transfer, and by dated records showing that waste was \\
certified before being transferred.
\end{tabular}

(3) Maintaining Certification. Low-level waste that has been certified as meeting the waste acceptance requirements for transfer to a storage, treatment, or disposal facility shall be managed in a manner that maintains its certification status.

From DOE G 435.1-1 Chapter IV: Compliance with this requirement is demonstrated by a program or procedure reflecting this requirement is present and site personnel are able to show that the storage of low-level waste containers is in a facility or manner where the containers would not be damaged by normal weather events, and cannot be accessed by unauthorized personnel. Further, each container can be traced to its certification and the information supporting that certification.

K. Waste Transfer. A documented process shall be established and implemented for transferring responsibility for management of low-level waste and for ensuring availability of relevant data. The following requirements are in addition to those in Chapter I of this Manual.

From DOE G 435.1-1 Chapter IV: Compliance with this requirement is demonstrated if facilities have procedures for the receipt of waste and the transfer of waste, as appropriate, which address the acquisition of waste and container data and the transfer of ownership, respectively. Further evidence of acceptable performance is facility records showing that data on the waste containers is available and accurate, and that documented transfer of responsibility occurs.

(1) Authorization. Low-level waste shall not be transferred to a storage, treatment, or disposal facility until personnel responsible for the facility receiving the waste authorize the transfer.

From DOE G 435.1-1 Chapter IV: Compliance with this requirement is demonstrated by sites having procedures that require a confirmation of authorization before releasing waste for transfer, and records showing that transfers are made in accordance with written authorizations.

(2) Data. Waste characterization data, container information, and generation, storage, treatment, and transportation information for low-level waste shall be

See J. above. Pre-certification checklists are cited in MCP-17000 and MCP-17500. Surveillances also are addressed in MCP-17500.

LWP-15011 $\$ 5$ provides general radioactive storage area requirements and $\$ 5.1 .7$ addresses outdoor storage of radioactive material.
Requirements controlling waste transfers into the facility are established in SD-24.1.3 and in IAG-443. MCP-17000 $\$ 4.8 .15$ specifies requirements for interfacility transfers.

MCP-17500 $\S 4$ addresses LLW to be transferred to NNSS.

See K. above. Facility Compliance Information disposed of at NNSS.

See K. above. 
Table 3. (continued).

Facility Name: TRA-617 Radioactive Materials Storage Area

\begin{tabular}{l} 
Chapter IV, LLW Requirements \\
\hline \multicolumn{1}{|c|}{ transferred with or be traceable to the waste. } \\
From DOE G 435.1-1 Chapter IV: Compliance with this \\
requirement is demonstrated if there are procedures \\
requiring that characterization and container data be \\
provided and maintained for each low-level waste transfer \\
and documented records of transfers show that the \\
information is being provided.
\end{tabular}

L. Packaging and Transportation. The following requirements are in addition to those in Chapter I of this Manual [DOE M 435.1-1 §I.1.E(11)].

(1) Packaging. If containers are used:

From DOE G 435.1-1 Chapter IV: Compliance with the packaging requirement is demonstrated by: (1) procedures which document proper packaging protocols; and (2) no trends of routine repackaging of low-level waste that is packaged after issuance of DOE O 435.1. Successful performance of this requirement is also demonstrated by a record of containers for which failure has not routinely occurred under management conditions. It is recognized that there may be failed containers for waste previously placed in storage. For those containers, the goal is to only have to repackage the waste one time after it is retrieved and characterized. Further, acceptable performance is demonstrated by containers of waste having marking and labeling that allows correlation with waste characterization data and container information.

(a) Low-level waste shall be packaged in a manner that provides containment and protection for the duration of the anticipated storage period and until disposal is achieved or until the waste has been removed from the container.

(b) When waste is packaged, vents or other measures shall be provided if the potential exists for pressurizing or generating flammable or explosive concentrations of gases within the waste container.

(c) Containers of low-level waste shall be marked such that See (1) above. their contents can be identified.

(2) Transportation. To the extent practical, the volume of waste and number of low-level waste shipments shall be minimized.

From DOE G 435.1-1 Chapter IV: Compliance with this requirement can be demonstrated by a combination of site procedures directing the efficient use of waste container capacity and documentation showing that low-level waste shipments are systematically planned and optimized to the extent practical.

See (1) above.

MCP-17000, Rev. 1, §4 addresses packaging requirements. Facility Compliance Information

See (1) and (2) below.

\begin{tabular}{|l|l|} 
M. Site Evaluation and Facility Design. The following & NA; this requirement addresses new radioactive waste \\
\hline
\end{tabular}


Table 3. (continued).

\begin{tabular}{|c|c|}
\hline \multicolumn{2}{|c|}{ Facility Name: TRA-617 Radioactive Materials Storage Area } \\
\hline Chapter IV, LLW Requirements & Facility Compliance Information \\
\hline $\begin{array}{l}\text { requirements are in addition to those in Chapter I of this } \\
\text { Manual. }\end{array}$ & $\begin{array}{l}\text { management facilities or modifications to existing } \\
\text { facilities. }\end{array}$ \\
\hline $\begin{array}{l}\text { (1) Site Evaluation. Proposed locations for low-level waste } \\
\text { facilities shall be evaluated to identify relevant features } \\
\text { that should be avoided or must be considered in facility } \\
\text { design and analyses. }\end{array}$ & See M. above. \\
\hline $\begin{array}{l}\text { (a) Each site proposed for a new low-level waste facility or } \\
\text { expansion of an existing low-level waste facility shall be } \\
\text { evaluated considering environmental characteristics, } \\
\text { geotechnical characteristics, and human activities, } \\
\text { including for a low-level waste disposal facility, the } \\
\text { capability of the site to demonstrate, at a minimum, } \\
\text { whether it is: }\end{array}$ & See M. above. \\
\hline $\begin{array}{l}1 \text { Located to accommodate the projected volume of waste } \\
\text { to be received; }\end{array}$ & See M. above. \\
\hline $\begin{array}{l}2 \text { Located in a flood plain, a tectonically active area, or in } \\
\text { the zone of water table fluctuation; and }\end{array}$ & See M. above. \\
\hline $\begin{array}{l}3 \text { Located where radionuclide migration pathways are } \\
\text { predictable and erosion and surface runoff can be } \\
\text { controlled. }\end{array}$ & See M. above. \\
\hline $\begin{array}{l}\text { (b) Proposed sites with environmental characteristics, } \\
\text { geotechnical characteristics, and human activities for } \\
\text { which adequate protection cannot be provided through } \\
\text { facility design shall be deemed unsuitable for the location } \\
\text { of the facility. }\end{array}$ & See M. above. \\
\hline $\begin{array}{l}\text { (c) Low-level waste disposal facilities shall be sited to } \\
\text { achieve long-term stability and to minimize, to the extent } \\
\text { practical, the need for active maintenance following final } \\
\text { closure. }\end{array}$ & See M. above. \\
\hline $\begin{array}{l}\text { (2) Low-Level Waste Treatment and Storage Facility } \\
\text { Design. The following facility requirements and general } \\
\text { design criteria, at a minimum, apply: }\end{array}$ & See M. above. \\
\hline $\begin{array}{l}\text { (a) Confinement. Low-level waste systems and } \\
\text { components shall be designed to maintain waste } \\
\text { confinement. }\end{array}$ & See M. above. \\
\hline (b) Ventilation. & See M. above. \\
\hline $\begin{array}{l}1 \text { Design of low-level waste treatment and storage facilities } \\
\text { shall include ventilation, if applicable, through an } \\
\text { appropriate filtration system to maintain the release of } \\
\text { radioactive material in airborne effluents within the } \\
\text { requirements and guidelines specified in applicable } \\
\text { requirements. }\end{array}$ & See M. above. \\
\hline $\begin{array}{l}2 \text { When conditions exist for generating gases in flammable } \\
\text { or explosive concentrations, ventilation systems or other } \\
\text { measures shall be provided to keep the gases in a non- }\end{array}$ & See M. above. \\
\hline
\end{tabular}


Table 3. (continued).

Facility Name: TRA-617 Radioactive Materials Storage Area

\begin{tabular}{l} 
Chapter IV, LLW Requirements \\
\hline $\begin{array}{l}\text { flammable and nonexplosive condition. Where } \\
\text { concentrations of explosive or flammable gases are } \\
\text { expected to approach the lower flammability limit, } \\
\text { measures shall be taken to prevent deflagration or } \\
\text { detonation. }\end{array}$
\end{tabular}

(c) Consideration of Decontamination and

Decommissioning. Areas in new and modifications to

existing low-level waste management facilities that are

subject to contamination with radioactive or other

hazardous materials shall be designed to facilitate

decontamination. For such facilities a proposed

decommissioning method or a conversion method leading

to reuse shall be described.

(d) Instrumentation and Control Systems. Engineering controls shall be incorporated in the design and engineering of low-level waste treatment and storage facilities to provide volume inventory data and to prevent spills, leaks, and overflows from tanks or confinement systems.

(e) Monitoring. Monitoring and/or leak detection capabilities shall be incorporated in the design and engineering of low-level waste treatment and storage facilities to provide rapid identification of failed confinement and/or other abnormal conditions.

(3) Low-Level Waste Disposal Facility Design. The following facility requirements and general design criteria, at a minimum, apply:

\begin{tabular}{|l|l|}
\hline $\begin{array}{l}\text { (a) Confinement. Low-level waste systems and } \\
\text { components shall be designed to maintain waste } \\
\text { confinement. }\end{array}$ & See M. above. \\
\hline (b) Ventilation. & See M. above. \\
$\begin{array}{l}1 \text { Design of low-level waste disposal facilities shall include } \\
\text { ventilation, if applicable, through an appropriate filtration } \\
\text { system to maintain the release of radioactive material in } \\
\text { airborne effluents within the requirements and guidelines } \\
\text { specified in applicable requirements. }\end{array}$ & See M. \\
\hline $\begin{array}{l}2 \text { When conditions exist for generating gases in flammable } \\
\text { or explosive concentrations, ventilation systems or other } \\
\text { measures shall be provided to keep the gases in a non- } \\
\text { flammable and non-explosive condition. Where } \\
\text { concentrations of explosive or flammable gases are } \\
\text { expected to approach the lower flammability limit, } \\
\text { measures shall be taken to prevent deflagration or } \\
\text { detonation. }\end{array}$ & See \\
\hline $\begin{array}{l}\text { (c) Stability. Low-level waste disposal facilities shall be } \\
\text { designed to achieve long-term stability and to minimize to }\end{array}$ & See M. above. \\
\hline
\end{tabular}

See M. above.

See M. above.

See M. above.

See M. above.

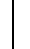
Facility Compliance Information

See M. above. 
Table 3. (continued).

\begin{tabular}{|c|c|}
\hline \multicolumn{2}{|c|}{ Facility Name: TRA-617 Radioactive Materials Storage Area } \\
\hline Chapter IV, LLW Requirements & Facility Compliance Information \\
\hline $\begin{array}{l}\text { the extent practical, the need for active maintenance } \\
\text { following final closure. }\end{array}$ & \\
\hline $\begin{array}{l}\text { (d) Control of Water. Low-level waste disposal facilities } \\
\text { shall be designed to minimize to the extent practical, the } \\
\text { contact of waste with water during and after disposal. }\end{array}$ & See M. above. \\
\hline $\begin{array}{l}\text { N. Storage and Staging. The following requirements are in } \\
\text { addition to those in Chapter I of this Manual [DOE M } \\
435.1-1 \S \mathrm{I} .2 . \mathrm{F}(13)] \text {. }\end{array}$ & $\begin{array}{l}\text { Not a facility-specific requirement. DOE Manual } \\
435.1-1 \text { §I.2.F(13) applies to field element managers. }\end{array}$ \\
\hline $\begin{array}{l}\text { (1) Storage Prohibitions. Low-level waste in storage shall } \\
\text { not be readily capable of detonation, explosive } \\
\text { decomposition, reaction at anticipated pressures and } \\
\text { temperatures, or explosive reaction with water. Prior to } \\
\text { storage, pyrophoric materials shall be treated, prepared, } \\
\text { and packaged to be nonflammable. }\end{array}$ & $\begin{array}{l}\text { IAG-443, Appendix A addresses limitations on } \\
\text { chemicals that can be stored in the facility. } \\
\text { The NNSS waste acceptance criteria does not allow } \\
\text { such waste (MCP-17500); therefore, such waste would } \\
\text { not be stored at this facility. }\end{array}$ \\
\hline $\begin{array}{l}\text { From DOE G 435.1-1 Chapter IV: Compliance with this } \\
\text { requirement is demonstrated by having waste acceptance } \\
\text { requirements which prohibit low-level waste that is } \\
\text { ignitable or explosive from being accepted for storage } \\
\text { unless it has been treated, and procedures for properly } \\
\text { preparing such materials for safe storage. }\end{array}$ & \\
\hline $\begin{array}{l}\text { (2) Storage Limit. Low-level waste that has an identified } \\
\text { path to disposal shall not be stored longer than one year } \\
\text { prior to disposal, except for storage for decay, or as } \\
\text { otherwise authorized by the Field Element Manager. }\end{array}$ & $\begin{array}{l}\text { MCP- } 17000 \S 4.8 .16 \text { addresses storage time limits and } \\
\text { waste that is to be stored longer than } 1 \text { year. }\end{array}$ \\
\hline $\begin{array}{l}\text { From DOE G } 435.1-1 \text { Chapter IV: Storage longer than one } \\
\text { year can be justified if the conditions for such storage are } \\
\text { approved by the Field Element Manager as part of the } \\
\text { radioactive waste management basis for the facility. }\end{array}$ & \\
\hline $\begin{array}{l}\text { Storage for radioactive decay for a period greater than } 1 \\
\text { year for waste that has an identified path to disposal is } \\
\text { allowed. Adequate justification and the supporting } \\
\text { information for storage for decay is to be documented in } \\
\text { the radioactive waste management basis for the facility in } \\
\text { which the storage will take place. }\end{array}$ & \\
\hline $\begin{array}{l}\text { Mixed waste. Under the Federal Facility Compliance Act } \\
\text { of 1992, DOE sites were required to develop Site } \\
\text { Treatment Plans to bring stored mixed low-level waste into } \\
\text { compliance with these requirements. The Site Treatment } \\
\text { Plan needs to be consulted and any mixed low-level waste } \\
\text { stored for the purpose of accumulation to facilitate } \\
\text { treatment must meet Resource Conservation and Recovery } \\
\text { Act storage requirements. There could be several ways } \\
\text { within different scenarios that this requirement can be met, } \\
\text { as illustrated by the examples below, however, there are } \\
\text { basically four ways to show compliance with the } \\
\text { requirement and include appropriate provisions in the } \\
\text { radioactive waste management basis for the facility in }\end{array}$ & \\
\hline
\end{tabular}


Table 3. (continued).

Facility Name: TRA-617 Radioactive Materials Storage Area

which it is stored.

Legacy waste. As discussed above, the intention of the requirement is not to force malicious compliance or heroic actions which would result in increased risk or safety concerns. Rather, the intention is that waste in storage longer than one year receives additional attention to ensure that the public, the workers, and the environment are protected from the hazards of the waste, and that progress is being made to dispose of the waste. There could be several ways within different scenarios that this requirement can be met, as illustrated by the examples below, however, there are basically four ways to show compliance with the requirement:

1) the radioactive waste management basis allows for storage for no more than one year.

2) the radioactive waste management basis allows for storage for no more than one year, or for storage for decay only for periods greater than a year, which are specified on a radionuclide basis.

3) the radioactive waste management basis allows for storage for more than one year, up to a specified period of time based on a documented technical evaluation that the waste can be stored in a manner that does not cause changes to the waste or waste packages that is detrimental to the safe storage of the waste, the final disposal of the waste or to meeting the disposal performance objectives.

4) the radioactive waste management basis allows for storage for decay (with specifics) and for storage for more than one year for other low-level waste, up to a specified period of time based on a documented technical evaluation that the waste can be stored in a manner that does not cause changes to the waste or waste packages that is detrimental to the safe storage of the waste, the final disposal of the waste or to meeting the disposal performance objectives.

Compliance with this requirement is demonstrated by the existence of a radioactive waste management basis for the storage facility approved by the Field Element Manager that includes the time frames that waste are allowed to be stored, the necessary justifications for storage for decay, and the necessary technical evaluations if storage is to extend significantly beyond the one-year time frame.

(3) Storage Integrity. Low-level waste shall be stored in a location and manner that protects the integrity of waste for the expected time of storage and minimizes worker exposure.

From DOE G 435.1-1 Chapter IV: However, in making a decision to use a facility for storage and in developing a

LWP-15011 $\$ 5$ provides general radioactive storage area requirements and $\$ 5.1 .7$ addresses outdoor storage of radioactive material.

Form 435.A01 documents compliance inspections. 
Table 3. (continued).

\begin{tabular}{|c|c|}
\hline \multicolumn{2}{|c|}{ Facility Name: TRA-617 Radioactive Materials Storage Area } \\
\hline Chapter IV, LLW Requirements & Facility Compliance Information \\
\hline $\begin{array}{l}\text { radioactive waste management basis for the activity, } \\
\text { particular attention to protection of workers is needed. }\end{array}$ & \\
\hline $\begin{array}{l}\text { Compliance with this requirement is demonstrated if sites } \\
\text { have storage capabilities for low-level waste that provide } \\
\text { protection to waste containers so that their integrity will } \\
\text { not be damaged through physical or chemical (corrosion) } \\
\text { processes and that keep personnel from spending extended } \\
\text { periods of time in the areas where low-level waste is } \\
\text { stored. }\end{array}$ & \\
\hline (4) Waste Characterization for Storage. & See below. \\
\hline $\begin{array}{l}\text { (a) Low-level waste that does not have an identified path to } \\
\text { disposal shall be characterized as necessary to meet the } \\
\text { data quality objectives and minimum characterization } \\
\text { requirements of this Chapter, to ensure safe storage, and to } \\
\text { facilitate disposal. }\end{array}$ & $\begin{array}{l}\text { This facility does not store LLW that does not have an } \\
\text { identified path to disposal. }\end{array}$ \\
\hline $\begin{array}{l}\text { (b) Characterization information for all low-level waste in } \\
\text { storage shall be maintained as a record in accordance with } \\
\text { the requirements for Records Management in Chapter I of } \\
\text { this Manual. }\end{array}$ & $\begin{array}{l}\text { SD-24.1.3 and MCP- } 17000 \S \S 4 \text { and } 5 \text { address the use } \\
\text { of IWTS and records. }\end{array}$ \\
\hline $\begin{array}{l}\text { From DOE G 435.1-1 Chapter IV: Compliance with this } \\
\text { requirement is demonstrated by documented procedures for } \\
\text { managing waste characterization and container information } \\
\text { on low-level waste as a Federal record. The records are } \\
\text { managed per the applicable policies and procedures for } \\
\text { records management referenced in DOE O } 200.1 \text { and } \\
\text { established at the applicable Field Element. }\end{array}$ & \\
\hline $\begin{array}{l}\text { (5) Container Inspection. A process shall be developed and } \\
\text { implemented for inspecting and maintaining containers of } \\
\text { low-level waste to ensure container integrity is not } \\
\text { compromised. }\end{array}$ & $\begin{array}{l}\text { LI-435 requires quarterly inspections of radioactive } \\
\text { waste containers if waste is stored outdoors or has } \\
\text { been in storage for greater than } 1 \text { year. }\end{array}$ \\
\hline $\begin{array}{l}\text { From DOE G 435.1-1 Chapter IV: Compliance with this } \\
\text { requirement is demonstrated by: (1) a documented process } \\
\text { for waste container inspection and maintenance; and (2) } \\
\text { documentation for all waste container inspections and } \\
\text { maintenance actions performed. }\end{array}$ & Form 435.A01 documents compliance inspections. \\
\hline $\begin{array}{l}\text { (6) Storage Management. Low-level waste storage shall be } \\
\text { managed to identify and segregate low-level waste from } \\
\text { mixed low-level waste. }\end{array}$ & NA; this facility does not store mixed LLW. \\
\hline $\begin{array}{l}\text { (7) Staging. Staging of low-level waste shall be for the } \\
\text { purpose of the accumulation of such quantities of waste as } \\
\text { necessary to facilitate transportation, treatment, and } \\
\text { disposal. Staging longer than } 90 \text { days shall meet the } \\
\text { requirements for storage above and in Chapter I of this } \\
\text { Manual. }\end{array}$ & NA; waste is not staged at this facility. \\
\hline $\begin{array}{l}\text { From DOE G } 435.1-1 \text { Chapter IV: The staging of low-level } \\
\text { waste needs to be addressed in the radioactive waste }\end{array}$ & \\
\hline
\end{tabular}


Table 3. (continued).

\begin{tabular}{|c|c|}
\hline \multicolumn{2}{|c|}{ Facility Name: TRA-617 Radioactive Materials Storage Area } \\
\hline Chapter IV, LLW Requirements & Facility Compliance Information \\
\hline $\begin{array}{l}\text { management basis for the facility that is performing the } \\
\text { staging. Generators, treatment facilities, and disposal } \\
\text { facilities that stage waste must ensure that the action of } \\
\text { staging is included and authorized as part of their } \\
\text { radioactive waste management basis for the affected } \\
\text { facilities, operations, or activities. }\end{array}$ & \\
\hline $\begin{array}{l}\text { Staging longer than } 90 \text { days must be justified, the } \\
\text { conditions for such storage met, and these practices } \\
\text { approved by the Field Element Manager as part of the } \\
\text { radioactive waste management basis for the facility. }\end{array}$ & \\
\hline $\begin{array}{l}\text { Compliance with this requirement is demonstrated by a } \\
\text { staging program that limits the temporary storage of waste } \\
\text { to only circumstances allowed in the requirement, } \\
\text { including justifications for any staging that exceeds the } 90 \text { - } \\
\text { day period, which is documented in the radioactive waste } \\
\text { management basis for the facility. }\end{array}$ & \\
\hline $\begin{array}{l}\text { O. Treatment. Low-level waste treatment to provide more } \\
\text { stable waste forms and to improve the long-term } \\
\text { performance of a low-level waste disposal facility shall be } \\
\text { implemented as necessary to meet the performance } \\
\text { objectives of the disposal facility. }\end{array}$ & NA; treatment is not performed in this facility. \\
\hline $\begin{array}{l}\text { From DOE G 435.1-1 Chapter IV Compliance with this } \\
\text { requirement is demonstrated when a treatment facility or } \\
\text { process ensures that treated waste will meet the minimum } \\
\text { waste form requirements of DOE M } 435.1 \text { and meet } \\
\text { additional disposal facility-specific waste acceptance } \\
\text { requirements for additional stability or long-term } \\
\text { performance of facilities that will receive the treated waste. }\end{array}$ & \\
\hline $\begin{array}{l}\text { P. Disposal. Low-level waste disposal facilities shall meet } \\
\text { the following requirements. }\end{array}$ & NA; LLW is not disposed of in this facility. \\
\hline $\begin{array}{l}\text { (1) Performance Objectives. Low-level waste disposal } \\
\text { facilities shall be sited, designed, operated, maintained, and } \\
\text { closed so that a reasonable expectation exists that the } \\
\text { following performance objectives will be met for waste } \\
\text { disposed of after September } 26,1988 \text { : }\end{array}$ & See P. above. \\
\hline $\begin{array}{l}\text { (a) Dose to representative members of the public shall not } \\
\text { exceed } 25 \mathrm{mrem}(0.25 \mathrm{mSv}) \text { in a year total effective dose } \\
\text { equivalent from all exposure pathways, excluding the dose } \\
\text { from radon and its progeny in air. }\end{array}$ & See P. above. \\
\hline $\begin{array}{l}\text { (b) Dose to representative members of the public via the air } \\
\text { pathway shall not exceed } 10 \mathrm{mrem}(0.10 \mathrm{mSv}) \text { in a year } \\
\text { total effective dose equivalent, excluding the dose from } \\
\text { radon and its progeny. }\end{array}$ & See P. above. \\
\hline $\begin{array}{l}\text { (c) Release of radon shall be less than an average flux of } \\
20 \mathrm{pCi} / \mathrm{m}^{2} / \mathrm{s}\left(0.74 \mathrm{~Bq} / \mathrm{m}^{2} / \mathrm{s}\right) \text { at the surface of the disposal } \\
\text { facility. Alternatively, a limit of } 0.5 \mathrm{pCi} / 1(0.0185 \mathrm{~Bq} / \mathrm{l}) \text { of } \\
\text { air may be applied at the boundary of the facility. }\end{array}$ & See P. above. \\
\hline
\end{tabular}


Table 3. (continued).

Facility Name: TRA-617 Radioactive Materials Storage Area

\section{Chapter IV, LLW Requirements}

(2) Performance Assessment. A site-specific radiological performance assessment shall be prepared and maintained for DOE low-level waste disposed of after September 26, 1988. The performance assessment shall include calculations for a 1,000 year period after closure of potential doses to representative future members of the public and potential releases from the facility to provide a reasonable expectation that the performance objectives identified in this Chapter are not exceeded as a result of operation and closure of the facility.

(a) Analyses performed to demonstrate compliance with the performance objectives in this Chapter, and to establish limits on concentrations of radionuclides for disposal based on the performance measures for inadvertent intruders in this Chapter shall be based on reasonable activities in the critical group of exposed individuals. Unless otherwise specified, the assumption of average living habits and exposure conditions in representative critical groups of individuals projected to receive the highest doses is appropriate. The likelihood of inadvertent intruder scenarios may be considered in interpreting the results of the analyses and establishing radionuclide concentrations, if adequate justification is provided.

(b) The point of compliance shall correspond to the point of highest projected dose or concentration beyond a 100 meter buffer zone surrounding the disposed waste. A larger or smaller buffer zone may be used if adequate justification is provided.

(c) Performance assessments shall address reasonably foreseeable natural processes that might disrupt barriers against release and transport of radioactive materials.

(d) Performance assessments shall use DOE-approved dose See P. above. coefficients (dose conversion factors) for internal and external exposure of reference adults.

(e) The performance assessment shall include a sensitivity/uncertainty analysis.

(f) Performance assessments shall include a demonstration that projected releases of radionuclides to the environment shall be maintained as low as reasonably achievable (ALARA).

(g) For purposes of establishing limits on radionuclides that may be disposed of near-surface, the performance assessment shall include an assessment of impacts to water resources.

(h) For purposes of establishing limits on the concentration See P. above. of radionuclides that may be disposed of near-surface, the performance assessment shall include an assessment of
See P. above.

See P. above.

See P. above.

See P. above.

See P. above.

See P. above. acility Compliance Information

See P. above.

See P. above.

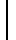


Table 3. (continued).

Facility Name: TRA-617 Radioactive Materials Storage Area

\begin{tabular}{|l|}
\hline \multicolumn{1}{|c|}{ Chapter IV, LLW Requirements } \\
\hline impacts calculated for a hypothetical person assumed to \\
inadvertently intrude for a temporary period into the low- \\
level waste disposal facility. For intruder analyses, \\
institutional controls shall be assumed to be effective in \\
deterring intrusion for at least 100 years following closure \\
The intruder analyses shall use performance measures for \\
chronic and acute exposure scenarios, respectively, of 100 \\
mrem (1 mSv) in a year and 500 mrem (5 mSv) total \\
effective dose equivalent excluding radon in air.
\end{tabular}

(3) Composite Analysis. For disposal facilities which received waste after September 26, 1988, a site-specific radiological composite analysis shall be prepared and maintained that accounts for all sources of radioactive material that may be left at the DOE site and may interact with the low- level waste disposal facility, contributing to the dose projected to a hypothetical member of the public from the existing or future disposal facilities. Performance measures shall be consistent with DOE requirements for protection of the public and environment and evaluated for a 1,000 year period following disposal facility closure. The composite analysis results shall be used for planning, radiation protection activities, and future use commitments to minimize the likelihood that current low- level waste disposal activities will result in the need for future corrective or remedial actions to adequately protect the public and the environment.

(4) Performance Assessment and Composite Analysis Maintenance. The performance assessment and composite analysis shall be maintained to evaluate changes that could affect the performance, design, and operating bases for the facility. Performance assessment and composite analysis maintenance shall include the conduct of research, field studies, and monitoring needed to address uncertainties or gaps in existing data. The performance assessment shall be updated to support the final facility closure. Additional iterations of the performance assessment and composite analysis shall be conducted as necessary during the postclosure period.

(a) Performance assessments and composite analyses shall See P. above. be reviewed and revised when changes in waste forms or containers, radionuclide inventories, facility design and operations, closure concepts, or the improved understanding of the performance of the waste disposal facility in combination with the features of the site on which it is located alter the conclusions or the conceptual model(s) of the existing performance assessment or composite analysis.

(b) A determination of the continued adequacy of the performance assessment and composite analysis shall be

See P. above.

See P. above.

See P. above. Facility Compliance Information

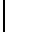

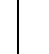


Table 3. (continued).

Facility Name: TRA-617 Radioactive Materials Storage Area

\begin{tabular}{l} 
Chapter IV, LLW Requirements \\
\hline \multicolumn{1}{|c|}{$\begin{array}{l}\text { made on an annual basis, and shall consider the results of } \\
\text { data collection and analysis from research, field studies, } \\
\text { and monitoring. }\end{array}$} \\
\hline (c) And
\end{tabular}

(c) Annual summaries of low-level waste disposal See P. above. operations shall be prepared with respect to the conclusions and recommendations of the performance assessment and composite analysis and a determination of the need to revise the performance assessment or composite analysis.

(5) Disposal Authorization. A disposal authorization statement shall be obtained prior to construction of a new low-level waste disposal facility. Field Elements with existing low-level waste disposal facilities shall obtain a disposal authorization statement in accordance with the schedule in the Complex-Wide Low-Level Waste Management Program Plan. The disposal authorization statement shall be issued based on a review of the facility's performance assessment, composite analysis, performance assessment and composite analysis maintenance, preliminary closure plan, and preliminary monitoring plan. The disposal authorization statement shall specify the limits and conditions on construction, design, operations, and closure of the low-level waste facility based on these reviews. A disposal authorization statement is a part of the radioactive waste management basis for a disposal facility. Failure to obtain a disposal authorization statement by the implementation date of this Order shall result in shutdown of the disposal facility.

(6) Disposal Facility Operations. The disposal facility See P. above. design and operation must be consistent with the disposal facility closure plan and lead to disposal facility closure that provides a reasonable expectation that performance objectives will be met. Low-level waste shall be disposed in such a manner that achieves the performance objectives stated in this Chapter, consistent with the disposal facility radiological performance assessment. Additional requirements include:

(a) Operating procedures shall be developed and implemented for low-level waste disposal facilities that protect the public, workers, and the environment; ensure the security of the facility; minimize subsidence during and after waste emplacement; achieve long-term stability and minimize the need for long-term active maintenance; and meet the requirements of the closure/post-closure plan.

(b) Permanent identification markers for disposal excavations and monitoring wells shall be emplaced.

(c) Low-level waste placement into disposal units shall minimize voids between waste containers. Voids within disposal units shall be filled to the extent practical.

See P. above. Facility Compliance Information

See P. above.

See P. above.

See P. above.

See P. above.

See P. above. 
Table 3. (continued).

\begin{tabular}{|c|c|}
\hline \multicolumn{2}{|c|}{ Facility Name: TRA-617 Radioactive Materials Storage Area } \\
\hline Chapter IV, LLW Requirements & Facility Compliance Information \\
\hline $\begin{array}{l}\text { Uncontainerized bulk waste shall also be placed in a } \\
\text { manner that minimizes voids and subsidence. }\end{array}$ & \\
\hline $\begin{array}{l}\text { (d) Operations are to be conducted so that active waste } \\
\text { disposal operations will not have an adverse effect on any } \\
\text { other disposal units. }\end{array}$ & See P. above. \\
\hline $\begin{array}{l}\text { (e) Operations shall include a process for tracking and } \\
\text { documenting low-level waste placement in the facility by } \\
\text { generator source. }\end{array}$ & See P. above. \\
\hline $\begin{array}{l}\text { (7) Alternate Requirements for Low-Level Waste Disposal } \\
\text { Facility Design and Operation. Requirements other than } \\
\text { those set forth in this Section for the design and operation } \\
\text { of a low-level waste disposal facility may be approved on a } \\
\text { specific basis if a reasonable expectation is demonstrated } \\
\text { that the disposal performance objectives will be met. }\end{array}$ & See P. above. \\
\hline $\begin{array}{l}\text { Q. Closure. The following requirements are in addition to } \\
\text { those in Chapter I of this Manual. }\end{array}$ & NA; LLW is not disposed of in this facility. \\
\hline $\begin{array}{l}\text { (1) Disposal Facility Closure Plans. A preliminary closure } \\
\text { plan shall be developed and submitted to Headquarters for } \\
\text { review with the performance assessment and composite } \\
\text { analysis. The closure plan shall be updated following } \\
\text { issuance of the disposal authorization statement to } \\
\text { incorporate conditions specified in the disposal } \\
\text { authorization statement. Closure plans shall: }\end{array}$ & See Q. above. \\
\hline $\begin{array}{l}\text { (a) Be updated as required during the operational life of the } \\
\text { facility. }\end{array}$ & See Q. above. \\
\hline $\begin{array}{l}\text { (b) Include a description of how the disposal facility will } \\
\text { be closed to achieve long-term stability and minimize the } \\
\text { need for active maintenance following closure and to } \\
\text { ensure compliance with the requirements of DOE 5400.5, } \\
\text { Radiation Protection of the Public and the Environment. }\end{array}$ & See Q. above. \\
\hline $\begin{array}{l}\text { (c) Include the total expected inventory of wastes to be } \\
\text { disposed of at the facility over the operational life of the } \\
\text { facility. }\end{array}$ & See Q. above. \\
\hline $\begin{array}{l}\text { (2) Disposal Facility Closure. Closure of a disposal facility } \\
\text { shall occur within a five-year period after it is filled to } \\
\text { capacity, or after the facility is otherwise determined to be } \\
\text { no longer needed. }\end{array}$ & See Q. above. \\
\hline $\begin{array}{l}\text { (a) Prior to facility closure, the final inventory of the low- } \\
\text { level waste disposed in the facility shall be prepared and } \\
\text { incorporated in the performance assessment and composite } \\
\text { analysis which shall be updated to support the closure of } \\
\text { the facility. }\end{array}$ & See Q. above. \\
\hline $\begin{array}{l}\text { (b) A final closure plan shall be prepared based on the final } \\
\text { inventory of waste disposed in the facility, the plan } \\
\text { implemented, and the updated performance assessment and }\end{array}$ & See Q. above. \\
\hline
\end{tabular}


Table 3. (continued).

\begin{tabular}{|c|c|}
\hline \multicolumn{2}{|c|}{ Facility Name: TRA-617 Radioactive Materials Storage Area } \\
\hline Chapter IV, LLW Requirements & Facility Compliance Information \\
\hline $\begin{array}{l}\text { composite analysis prepared in support of the facility } \\
\text { closure. }\end{array}$ & \\
\hline $\begin{array}{l}\text { (c) Institutional control measures shall be integrated into } \\
\text { land use and stewardship plans and programs, and shall } \\
\text { continue until the facility can be released pursuant to DOE } \\
\text { 5400.5, Radiation Protection of the Public and the } \\
\text { Environment. }\end{array}$ & See Q. above. \\
\hline $\begin{array}{l}\text { (d) The location and use of the facility shall be filed with } \\
\text { the local authorities responsible for land use and zoning. }\end{array}$ & See Q. above. \\
\hline $\begin{array}{l}\text { R. Monitoring. The following requirements are in addition } \\
\text { to those in Chapter I of this Manual [DOE M 435.1-1 } \\
\S \text { I.1.E(7)]. }\end{array}$ & See (1), (2), and (3) below. \\
\hline $\begin{array}{l}\text { (1) All Waste Facilities. Parameters that shall be sampled } \\
\text { or monitored, at a minimum, include: temperature, pressure } \\
\text { (for closed systems), radioactivity in ventilation exhaust } \\
\text { and liquid effluent streams, and flammable or explosive } \\
\text { mixtures of gases. Facility monitoring programs shall } \\
\text { include verification that passive and active control systems } \\
\text { have not failed. }\end{array}$ & $\begin{array}{l}\text { Monitoring requirements at INL radioactive waste } \\
\text { management facilities are tailored for the specific } \\
\text { facility to enable timely indication of developing } \\
\text { problems. Existing radiological control procedures and } \\
\text { assessments are followed/completed to monitor waste } \\
\text { facilities. }\end{array}$ \\
\hline $\begin{array}{l}\text { From DOE G 435.1-1 Chapter IV: The minimum } \\
\text { parameters specified in the requirement were selected } \\
\text { based on their potential significance for anticipating and } \\
\text { identifying undesirable conditions at low-level waste } \\
\text { management facilities. Each facility's radioactive waste } \\
\text { management basis should include an evaluation of the } \\
\text { applicability and significance of the minimum parameters. } \\
\text { This evaluation also needs to consider additional } \\
\text { parameters to be sampled or monitored to ensure the } \\
\text { protection of the public health, the environment, and the } \\
\text { workers. If a minimum parameter specified in the } \\
\text { requirement is deemed to be not applicable in any way to } \\
\text { the active operation of that facility, then that justification } \\
\text { should be included in the radioactive waste management } \\
\text { basis and when approved constitutes an exemption to the } \\
\text { manual. }\end{array}$ & $\begin{array}{l}\text { frequency of radiological control surveys of all } \\
\text { radiological areas. MCP-139 specifies the use of } \\
\text { Form } 441 . \text { A34. This form is referred to as the "routine } \\
\text { sheet" and is to be used by facility radiological control } \\
\text { foremen to list radiological areas that are to be } \\
\text { surveyed, the survey periods, and methods. }\end{array}$ \\
\hline $\begin{array}{l}\text { Verification activities are part of the radioactive waste } \\
\text { management basis as a condition for operation and } \\
\text { documented appropriately. }\end{array}$ & \\
\hline $\begin{array}{l}\text { Compliance with this requirement is demonstrated if } \\
\text { monitoring or sampling for the stated parameters is } \\
\text { performed for all facilities with a precision, accuracy, and } \\
\text { frequency consistent with timely identification of } \\
\text { developing problems and a justification exists in the } \\
\text { approved radioactive waste management basis for those } \\
\text { specified parameters which are not monitored or sampled. }\end{array}$ & \\
\hline $\begin{array}{l}\text { (2) Liquid Waste Storage Facilities. For facilities storing } \\
\text { liquid low-level waste, the following shall also be }\end{array}$ & NA; liquid waste is not stored at this facility. \\
\hline
\end{tabular}


Table 3. (continued).

\begin{tabular}{|c|c|}
\hline \multicolumn{2}{|c|}{ Facility Name: TRA-617 Radioactive Materials Storage Area } \\
\hline Chapter IV, LLW Requirements & Facility Compliance Information \\
\hline $\begin{array}{l}\text { monitored: liquid level and/or waste volume, and } \\
\text { significant waste chemistry parameters. }\end{array}$ & \\
\hline $\begin{array}{l}\text { (3) Disposal Facilities. A preliminary monitoring plan for a } \\
\text { low-level waste disposal facility shall be prepared and } \\
\text { submitted to Headquarters for review with the performance } \\
\text { assessment and composite analysis. The monitoring plan } \\
\text { shall be updated within one year following issuance of the } \\
\text { disposal authorization statement to incorporate and } \\
\text { implement conditions specified in the disposal } \\
\text { authorization statement. }\end{array}$ & NA; LLW is not disposed of in this facility. \\
\hline $\begin{array}{l}\text { (a) The site-specific performance assessment and } \\
\text { composite analysis shall be used to determine the media, } \\
\text { locations, radionuclides, and other substances to be } \\
\text { monitored. }\end{array}$ & See (3) above. \\
\hline $\begin{array}{l}\text { (b) The environmental monitoring program shall be } \\
\text { designed to include measuring and evaluating releases, } \\
\text { migration of radionuclides, disposal unit subsidence, and } \\
\text { changes in disposal facility and disposal site parameters } \\
\text { which may affect long-term performance. }\end{array}$ & See (3) above. \\
\hline $\begin{array}{l}\text { (c) The environmental monitoring programs shall be } \\
\text { capable of detecting changing trends in performance to } \\
\text { allow application of any necessary corrective action prior } \\
\text { to exceeding the performance objectives in this Chapter. }\end{array}$ & See (3) above. \\
\hline
\end{tabular}

\subsection{TRA-621, Nuclear Materials Inspection and Storage Facility}

1. Facility description: The NMIS Facility, TRA-621, is a fuel storage and safeguards and security facility that consolidates the storage of special nuclear materials, consolidates the fuel inspection activities of quality assurance, and consolidates the nondestructive assay activities of Safeguards and Security. Facility activities include making and receiving shipments, inspecting nuclear material, records storage, surveillances, inventory, confirmatory measurements, storing material, and performing safeguards-related assays.

2. Hazard category: Hazard Category 2 Nuclear Facility

3. Radioactive waste management activities at this facility: No radioactive waste has been recently generated from this facility. There is a potential that examinations conducted in this facility could generate LLW; therefore, the facility is included as a LLW generator in Table 4. As a potential LLW generator, the standard possibilities to generate mixed LLW and TSCA-regulated LLW exist and the appropriate management procedures are identified.

\section{RWMB documents/programs:}

a) Safety basis/hazards analysis:

- IAG-50, "INL Authorization Agreement for the Advanced Test Reactor (ATR) Complex Nuclear Materials Inspection and Storage (NMIS) Facility"

- LST-119, "INL Safety Basis List for the Nuclear Material Inspection And Storage (NMIS) Facility" 
- LST-213, "NMIS Nuclear Safety Basis Implementation Matrix"

- SAR-154, "Safety Analysis Report for the Nuclear Materials Inspection And Storage (NMIS) Facility TRA-621"

b) Laboratory-wide:

- LI-435, "Waste Management Routine Field Activities"

- LWP-8000, Environmental Instructions for Facilities, Processes, Materials and Equipment"

- LWP-13840, "Management of Issues, Observations, and Noteworthy Practices"

- LWP-14002, "Timeout and Stop Work Authority"

- LWP-15011, "Radioactive Material Areas and Radioactive Storage Areas"

- LWP-17000, "Waste Management"

- MCP-17000, "Waste Generator Services Waste Management"

- MCP-17410, "Management of Waste Storage Areas"

- MCP-17500, "Waste Generator Services Certification of Waste Shipments to the Nevada Test Site"

- PDD-17000, "Waste Management Program"

- PLN-114, "INL Emergency Plan/RCRA Contingency Plan

c) Facility-specific:

- None.

Table 4 presents the facility compliance information for Chapter IV, "Low-level Waste Requirements."

Table 4. TRA-621, Nuclear Materials Inspection and Storage Facility, DOE Manual 435.1-1 low-level waste requirements and facility compliance information.

\begin{tabular}{|c|c|}
\hline \multicolumn{2}{|c|}{ Facility Name: TRA-621, Nuclear Materials Inspection and Storage Facility } \\
\hline Chapter IV, LLW Requirements & Facility Compliance Information \\
\hline $\begin{array}{l}\text { A. Definition of Low-Level Waste. Low-level radioactive } \\
\text { waste is radioactive waste that is not high-level radioactive } \\
\text { waste, spent nuclear fuel, transuranic waste, byproduct } \\
\text { material (as defined in section } 11 \text { e.( } 2 \text { ) of the Atomic Energy } \\
\text { Act of } 1954 \text {, as amended), or naturally occurring radioactive } \\
\text { material. } \\
\text { (From DOE G } 435.1-1 \text { Chapter IV: Low-level radioactive } \\
\text { waste is defined by what it is not. The guidance on } \\
\text { definitions in Chapters II and III should be consulted first } \\
\text { for making a determination on how to properly manage a } \\
\text { suspect waste stream.) }\end{array}$ & $\begin{array}{l}\text { This requirement provides the criteria for } \\
\text { determining which DOE radioactive waste is to be } \\
\text { managed as LLW in accordance with DOE Manual } \\
435.1-1 \text {, Chapter IV. } \\
\text { Radioactive waste managed at this facility under the } \\
\text { requirements of this chapter is not managed under the } \\
\text { requirements of DOE Manual } 435.1-1 \text {, Chapter II or } \\
\text { Chapter III. }\end{array}$ \\
\hline $\begin{array}{l}\text { B. Management of Specific Wastes. The following provide } \\
\text { for management of specific wastes as low-level waste in } \\
\text { accordance with the requirements in this Chapter: }\end{array}$ & See (1), (2), (3), and (4) below. \\
\hline $\begin{array}{l}\text { (1) Mixed Low-Level Waste. Low-level waste determined to } \\
\text { contain both source, special nuclear, or byproduct material } \\
\text { subject to the Atomic Energy Act of 1954, as amended, and a } \\
\text { hazardous component subject to the Resource Conservation } \\
\text { and Recovery Act (RCRA), as amended, shall be managed in } \\
\text { accordance with the requirements of RCRA and DOE O } \\
\text { 435.1, Radioactive Waste Management, and this Manual. }\end{array}$ & $\begin{array}{l}\text { If generated, this facility would manage mixed LLW } \\
\text { in SAA. Management of SAAs is addressed in } \\
\text { MCP-17410, and overall management of mixed } \\
\text { waste is addressed in MCP-17000. }\end{array}$ \\
\hline
\end{tabular}


Table 4. (continued).

\begin{tabular}{|c|c|}
\hline \multicolumn{2}{|c|}{ Facility Name: TRA-621, Nuclear Materials Inspection and Storage Facility } \\
\hline Chapter IV, LLW Requirements & Facility Compliance Information \\
\hline $\begin{array}{l}\text { (2) TSCA-Regulated Waste. Low-level waste containing } \\
\text { polychlorinated biphenyls, asbestos, or other such regulated } \\
\text { toxic components shall be managed in accordance with } \\
\text { requirements derived from the Toxic Substances Control } \\
\text { Act, as amended, DOE O } 435.1 \text {, Radioactive Waste } \\
\text { Management, and this Manual. }\end{array}$ & $\begin{array}{l}\text { If generated, this facility would manage } \\
\text { TSCA-regulated waste in accordance with MCP- } \\
17410 \text { and MCP- } 17000 .\end{array}$ \\
\hline $\begin{array}{l}\text { (3) Accelerator-Produced Waste. Radioactive waste } \\
\text { produced as a result of operations of DOE accelerators is } \\
\text { low-level waste and shall be managed in accordance with } \\
\text { DOE O 435.1, Radioactive Waste Management, and this } \\
\text { Manual, and all applicable Federal or State requirements. }\end{array}$ & $\begin{array}{l}\text { NA; this facility does not manage accelerator- } \\
\text { produced waste. }\end{array}$ \\
\hline $\begin{array}{l}\text { (4) } 11 \text { e.(2) and Naturally Occurring Radioactive Material. } \\
\text { Small quantities of } 11 \text { e.(2) byproduct material and naturally } \\
\text { occurring radioactive material may be managed as low-level } \\
\text { waste provided they can be managed to meet the } \\
\text { requirements for low-level waste disposal in Section IV.P of } \\
\text { this Manual. }\end{array}$ & $\begin{array}{l}\text { NA; this facility does not manage naturally occurring } \\
\text { radioactive material. }\end{array}$ \\
\hline $\begin{array}{l}\text { C. Complex-Wide Low-Level Waste Management Program. } \\
\text { A complex-wide program and plan shall be developed as } \\
\text { described under Responsibilities, } 2 . \mathrm{B} \text { and } 2 . \mathrm{D} \text {, in Chapter I } \\
\text { of this Manual. }\end{array}$ & $\begin{array}{l}\text { Not a facility-specific requirement. DOE Manual } \\
435.1-1 \S \text { I.2.B and } \S I .2 . D \text { apply to the Assistant } \\
\text { Secretary for Environmental Management and the } \\
\text { Deputy Assistant Secretary for Waste Management, } \\
\text { respectively. }\end{array}$ \\
\hline $\begin{array}{l}\text { D. Radioactive Waste Management Basis. Low-level waste } \\
\text { facilities, operations, and activities shall have a radioactive } \\
\text { waste management basis consisting of physical and } \\
\text { administrative controls to ensure the protection of workers, } \\
\text { the public, and the environment. The following specific } \\
\text { waste management controls shall be part of the radioactive } \\
\text { waste management basis: }\end{array}$ & $\begin{array}{l}\text { The RWMB provides the regulatory framework for } \\
\text { management of radioactive waste at INL. It } \\
\text { specifically identifies facility management and } \\
\text { implementing documents for the generation, storage, } \\
\text { treatment, and disposal of radiological waste. } \\
\text { LLW management is addressed in PDD-17000. } \\
\text { Routine waste management activities are conducted } \\
\text { in accordance with LI- } 435 \text {. } \\
\text { SAR-154 establishes this facility as a Hazard } \\
\text { Category } 2 \text { Nuclear facility. }\end{array}$ \\
\hline $\begin{array}{l}\text { (1) Generators. The waste certification program. } \\
\text { From DOE G } 435.1-1 \text { Chapter IV: } \\
\text { For a facility that generates low-level waste, the radioactive } \\
\text { waste management basis is to include the program for } \\
\text { certifying that waste meets the waste acceptance } \\
\text { requirements of the facility(ies) to which the waste will be } \\
\text { sent. }\end{array}$ & $\begin{array}{l}\text { See J. below for waste certification program } \\
\text { requirements. }\end{array}$ \\
\hline $\begin{array}{l}\text { (2) Treatment Facilities. certification program. The waste } \\
\text { acceptance requirements and the waste [sic] } \\
\text { From DOE G 435.1-1 Chapter IV: } \\
\text { Facilities that store or treat low-level waste are to have } \\
\text { approved waste acceptance requirements (see DOE M }\end{array}$ & $\begin{array}{l}\text { NA; this facility is not a radioactive waste treatment } \\
\text { facility. }\end{array}$ \\
\hline
\end{tabular}


Table 4. (continued).

\begin{tabular}{|c|c|}
\hline \multicolumn{2}{|c|}{ Facility Name: TRA-621, Nuclear Materials Inspection and Storage Facility } \\
\hline Chapter IV, LLW Requirements & Facility Compliance Information \\
\hline $\begin{array}{l}435.1-1 \text {, Section IV.G) prior to the issuance of a radioactive } \\
\text { waste management basis. }\end{array}$ & \\
\hline $\begin{array}{l}\text { A facility that stores or treats waste also is generally } \\
\text { expected to have a waste certification program. Waste from } \\
\text { these facilities will have to be certified as meeting the waste } \\
\text { acceptance requirements of the facility to which it will be } \\
\text { transferred, and the facilities have the potential for } \\
\text { generating radioactive waste (e.g., secondary processing } \\
\text { streams from treatment, monitoring and sampling, } \\
\text { radioactive release cleanup). Consequently, storage and } \\
\text { treatment facilities should also have an approved waste } \\
\text { certification program as part of their radioactive waste } \\
\text { management basis. }\end{array}$ & \\
\hline $\begin{array}{l}\text { As part of the radioactive waste management basis, site } \\
\text { personnel needs to implement a system or process for } \\
\text { tracking the waste inventory at a storage, treatment, or } \\
\text { disposal facility. }\end{array}$ & \\
\hline $\begin{array}{l}\text { (3) Storage Facilities. The waste acceptance requirements } \\
\text { and the waste certification program. }\end{array}$ & $\begin{array}{l}\text { NA; this facility is not a radioactive waste storage } \\
\text { facility. }\end{array}$ \\
\hline From DOE G 435.1-1 Chapter IV: & \\
\hline $\begin{array}{l}\text { Facilities that store or treat low-level waste are to have } \\
\text { approved waste acceptance requirements (see DOE M } \\
435.1-1 \text {, Section IV.G) prior to the issuance of a radioactive } \\
\text { waste management basis. }\end{array}$ & \\
\hline $\begin{array}{l}\text { A facility that stores or treats waste also is generally } \\
\text { expected to have a waste certification program. Waste from } \\
\text { these facilities will have to be certified as meeting the waste } \\
\text { acceptance requirements of the facility to which it will be } \\
\text { transferred, and the facilities have the potential for } \\
\text { generating radioactive waste (e.g., secondary processing } \\
\text { streams from treatment, monitoring and sampling, } \\
\text { radioactive release cleanup). Consequently, storage and } \\
\text { treatment facilities should also have an approved waste } \\
\text { certification program as part of their radioactive waste } \\
\text { management basis. }\end{array}$ & \\
\hline $\begin{array}{l}\text { As part of the radioactive waste management basis, site } \\
\text { personnel needs to implement a system or process for } \\
\text { tracking the waste inventory at a storage, treatment, or } \\
\text { disposal facility. }\end{array}$ & \\
\hline $\begin{array}{l}\text { (4) Disposal Facilities. The performance assessment, } \\
\text { composite analysis, disposal authorization statement, closure } \\
\text { plan, waste acceptance requirements, and monitoring plan. }\end{array}$ & $\begin{array}{l}\text { NA; this facility is not a radioactive waste disposal } \\
\text { facility. }\end{array}$ \\
\hline $\begin{array}{l}\text { E. Contingency Actions. The following requirements are in } \\
\text { addition to those in Chapter I of this Manual [DOE M } \\
\text { 435.1-1 §I.1.E(5)]. }\end{array}$ & $\begin{array}{l}\text { Not a facility-specific requirement. DOE Manual } \\
435.1-1 \text { §I.1.E(5) addresses the sitewide emergency } \\
\text { management system. The INL plan is provided in } \\
\text { PLN-114. }\end{array}$ \\
\hline
\end{tabular}


Table 4. (continued).

\begin{tabular}{|c|c|}
\hline \multicolumn{2}{|c|}{ Facility Name: TRA-621, Nuclear Materials Inspection and Storage Facility } \\
\hline Chapter IV, LLW Requirements & Facility Compliance Information \\
\hline $\begin{array}{l}\text { (1) Contingency Storage. For off-normal or emergency } \\
\text { situations involving high activity or high hazard liquid low- } \\
\text { level waste storage or treatment, spare capacity with } \\
\text { adequate capabilities shall be maintained to receive the } \\
\text { largest volume of liquid contained in any one storage tank or } \\
\text { treatment facility. Tanks or other facilities that are } \\
\text { designated low-level waste contingency storage shall be } \\
\text { maintained in an operational condition when waste is } \\
\text { present and shall meet the requirements of DOE O } 435.1 \text {, } \\
\text { Radioactive Waste Management, and this Manual. } \\
\text { From DOE G } 435.1-1 \text { Chapter IV: } \\
\text { Compliance with these requirements is demonstrated if } \\
\text { adequate spare capacity and transfer equipment exists for } \\
\text { emergency transfers of all high activity and high hazard } \\
\text { liquid low-level waste. In addition, the capability to perform } \\
\text { emergency transfers is demonstrated by having waste } \\
\text { transfer routings identified, operational procedures to direct } \\
\text { transfers, staff trained to the procedures, and records } \\
\text { showing that the spare capacity and transfer capability are } \\
\text { kept in operating condition. }\end{array}$ & NA; this facility does not store liquid LLW in tanks. \\
\hline $\begin{array}{l}\text { (2) Transfer Equipment. Pipelines and auxiliary facilities } \\
\text { necessary for the transfer of high activity or high hazard } \\
\text { liquid low-level waste to contingency storage shall be } \\
\text { maintained in an operational condition when waste is } \\
\text { present and shall meet the requirements of DOE O } 435.1 \text {, } \\
\text { Radioactive Waste Management, and this Manual. } \\
\text { From DOE G } 435.1-1 \text { Chapter IV: } \\
\text { Compliance with these requirements is demonstrated if } \\
\text { adequate spare capacity and transfer equipment exists for } \\
\text { emergency transfers of all high activity and high hazard } \\
\text { liquid low-level waste. In addition, the capability to perform } \\
\text { emergency transfers is demonstrated by having waste } \\
\text { transfer routings identified, operational procedures to direct } \\
\text { transfers, staff trained to the procedures, and records } \\
\text { showing that the spare capacity and transfer capability are } \\
\text { kept in operating condition. }\end{array}$ & NA; this facility does not store liquid LLW in tanks. \\
\hline $\begin{array}{l}\text { F. Corrective Actions. I of this Manual. The following } \\
\text { requirements are in addition to those in Chapter [sic] } \\
\text { From DOE G 435.1-1 Chapter IV: } \\
\text { Compliance with DOE M 435.1-1 §I.2.G.(1) is } \\
\text { demonstrated by records showing what corrective actions } \\
\text { were taken to remedy situations in the radioactive waste } \\
\text { management system. } \\
\text { Compliance with DOE M } 435.1-1 \S \mathrm{I} .2 . \text { G.(2) is } \\
\text { demonstrated by having the necessary procedures, } \\
\text { mechanisms, and training in place to effect shutdown or }\end{array}$ & $\begin{array}{l}\text { The INL-wide procedure addressing problem } \\
\text { identification as required by DOE Manual 435.1-1 } \\
\text { §I.2.G.(1) is LWP-13840, which implements the } \\
\text { laboratory's corrective action system. } \\
\text { The INL-wide procedure addressing shutdown or } \\
\text { curtailment of activities as required by DOE } \\
\text { Manual 435.1-1 §I.2.G.(2) is LWP-14002. }\end{array}$ \\
\hline
\end{tabular}


Table 4. (continued).

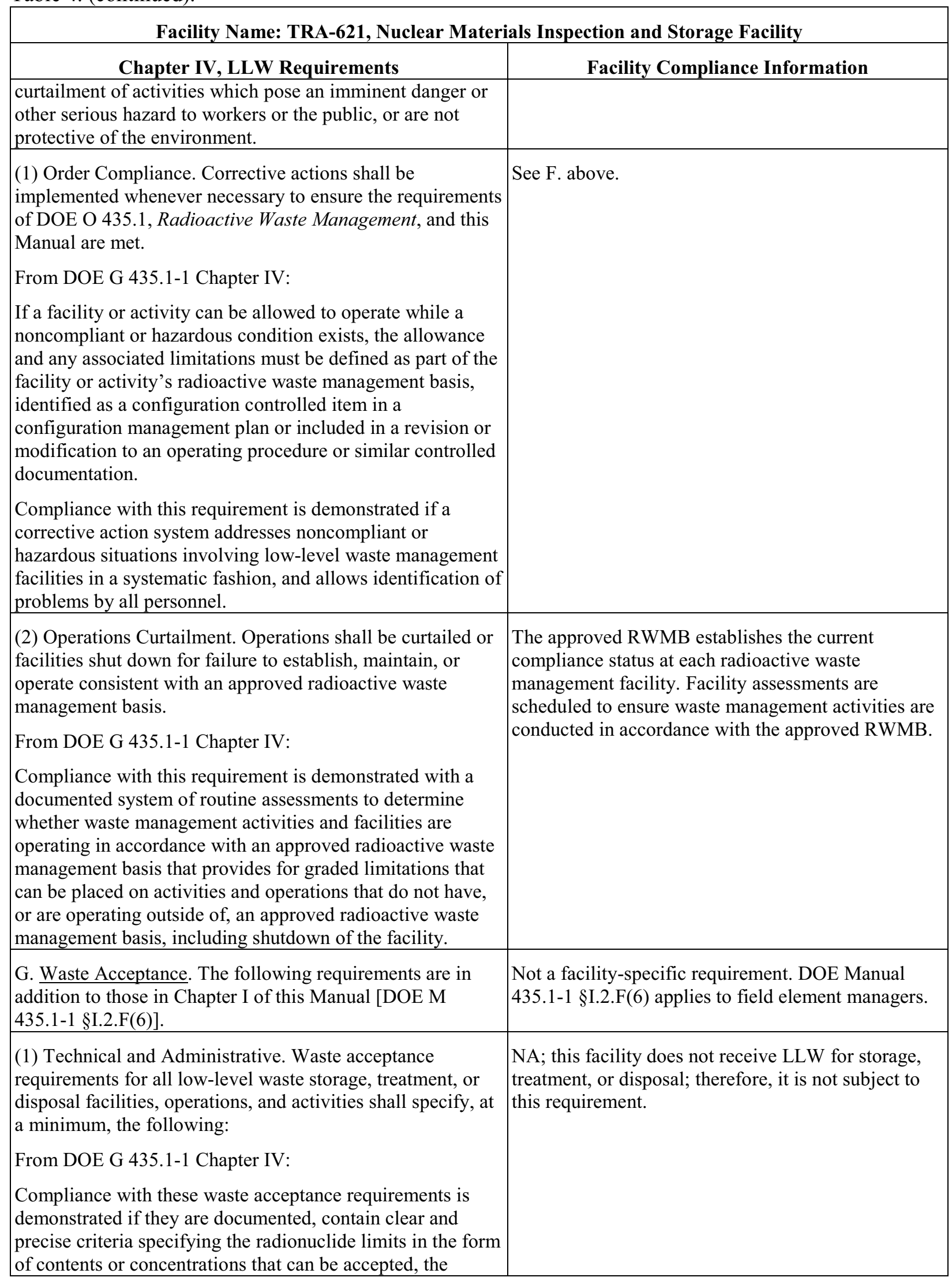


Table 4. (continued).

Facility Name: TRA-621, Nuclear Materials Inspection and Storage Facility

\begin{tabular}{|l|}
\hline \multicolumn{1}{|c|}{ Chapter IV, LLW Requirements } \\
\hline $\begin{array}{l}\text { limitations and prohibitions on waste forms and packages } \\
\text { that can be received, and the limits, prohibitions, or } \\
\text { instructions concerning any other technical information so } \\
\text { that the waste is compatible with the safety basis of the } \\
\text { facility, and which will result in acceptable waste at } \\
\text { subsequent steps in managing the low-level waste.) }\end{array}$ \\
\hline $\begin{array}{l}\text { (a) Allowable activities and/or concentrations of specific } \\
\text { radionuclides. }\end{array}$ \\
$\begin{array}{l}\text { (b) Acceptable waste form and/or container requirements } \\
\text { that ensure the chemical and physical stability of waste } \\
\text { under conditions that might be encountered during } \\
\text { transportation, storage, treatment, or disposal. }\end{array}$ \\
\hline
\end{tabular}

(c) Restrictions or prohibitions on waste, materials, or containers that may adversely affect waste handlers or compromise facility or waste container performance.

(d) The following are additional waste acceptance requirements that shall be specified in low-level waste disposal facility waste acceptance requirements:

1 Low-level waste must contribute to and not detract from achieving long-term stability of the facility, minimizing the need for long-term active maintenance, minimizing subsidence, and minimizing contact of water with waste. Void spaces within the waste and, if containers are used, between the waste and its container shall be reduced to the extent practical.

2 Liquid low-level waste or low-level waste containing free $\quad$ See (d) above. liquid must be converted into a form that contains as little freestanding liquid as is reasonably achievable, but in no case shall the liquid exceed 1 percent of the waste volume when the low-level waste is in a disposal container, or 0.5 percent of the waste volume after it is processed to a stable form.

3 Low-level waste must not be readily capable of detonation See (d) above. or of explosive decomposition or reaction at anticipated pressures and temperatures, or of explosive reaction with water. Pyrophoric materials contained in waste shall be treated, prepared, and packaged to be nonflammable.

4 Low-level waste must not contain, or be capable of generating by radiolysis or biodegradation, quantities of toxic gases, vapors, or fumes harmful to the public or workers or disposal facility personnel, or harmful to the long-term structural stability of the disposal site.

5 Low-level waste in a gaseous form must be packaged such See (d) above. that the pressure does not exceed 1.5 atmospheres absolute at $20 \mathrm{C}$. [sic]

(e) The basis, procedures, and levels of authority required

See (d) above.

See (1) above.

See (1) above.

See (1) above.

NA; this facility is not a LLW disposal facility.

See (d) above.

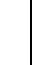


Table 4. (continued).

Facility Name: TRA-621, Nuclear Materials Inspection and Storage Facility

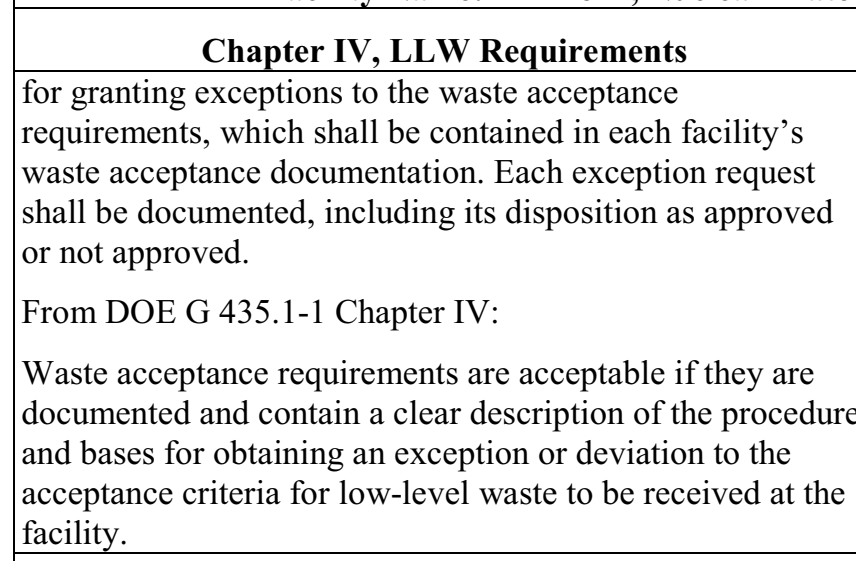

(2) Evaluation and Acceptance. The receiving facility shall evaluate waste for acceptance, including confirmation that the technical and administrative requirements have been met. A process for the disposition of non-conforming wastes shall be established.

From DOE G 435.1-1 Chapter IV:

Compliance with the waste acceptance requirements for a low-level waste management facility is demonstrated if they include a process for evaluation and acceptance of incoming waste to ensure the acceptance criteria of the facility receiving the waste are met that includes one of or a combination of: (1) testing, sampling, and analysis of representative samples of waste upon receipt; (2) testing, sampling, and analysis of split samples of waste taken at the generator site; (3) evaluation of testing, sampling, and analysis of data provided by the generator, or (4) audits, reviews, surveillance, or observations of generator waste certification programs and characterization activities.

Additionally, acceptable waste acceptance requirements for a storage, treatment or disposal facility will have documented procedures and actions to be taken if a waste that does not conform to the waste acceptance criteria is received at the facility.

H. Waste Generation Planning. The following requirements are in addition to those in Chapter I of this Manual [DOE M 435.1-1 §I.2.F(7)].

(1) Life-Cycle Planning. Prior to waste generation, planning shall be performed to address the entire life cycle for all low-level waste streams.

From DOE G 435.1-1 Chapter IV:

Compliance with this planning requirement is demonstrated by the individual sites establishing a process for evaluating the life-cycle of low-level waste prior to its generation, including the identification of low-level wastes with no path to disposal and appropriate records justifying the newly generated low-level waste stream(s), and site personnel
NA; this facility does not store, treat, or dispose of LLW.
Not a facility-specific requirement. DOE Manual 435.1-1 §I.2.F(7) applies to field element managers.

PDD-17000 and LWP-17000 provide direction to the waste generators for waste generation planning to address the entire life cycle. 
Table 4. (continued).

\begin{tabular}{|c|c|}
\hline \multicolumn{2}{|c|}{ Facility Name: TRA-621, Nuclear Materials Inspection and Storage Facility } \\
\hline Chapter IV, LLW Requirements & Facility Compliance Information \\
\hline $\begin{array}{l}\text { possessing planning information showing the location(s) } \\
\text { where low-level waste will be stored, treated, and/or } \\
\text { disposed along with a confirmation that the personnel } \\
\text { managing the facilities agree that the low-level waste may } \\
\text { be managed at those facilities. }\end{array}$ & \\
\hline $\begin{array}{l}\text { (2) Waste with No Identified Path to Disposal. Low-level } \\
\text { waste streams with no identified path to disposal shall be } \\
\text { generated only in accordance with approved conditions } \\
\text { which, at a minimum, shall address: }\end{array}$ & $\begin{array}{l}\text { This facility is not generating radioactive waste that } \\
\text { does not have an identified path to disposal. }\end{array}$ \\
\hline (a) Programmatic need to generate the waste; & See (2) above. \\
\hline $\begin{array}{l}\text { (b) Characteristics and issues preventing the disposal of the } \\
\text { waste; }\end{array}$ & See (2) above. \\
\hline $\begin{array}{l}\text { (c) Safe storage of the waste until disposal can be achieved; } \\
\text { and }\end{array}$ & See (2) above. \\
\hline $\begin{array}{l}\text { (d) Activities and plans for achieving final disposal of the } \\
\text { waste. }\end{array}$ & See (2) above. \\
\hline $\begin{array}{l}\text { I. Waste Characterization. Low-level waste shall be } \\
\text { characterized using direct or indirect methods, and the } \\
\text { characterization documented in sufficient detail to ensure } \\
\text { safe management and compliance with the waste acceptance } \\
\text { requirements of the facility receiving the waste. } \\
\text { From DOE G 435.1-1 Chapter IV: } \\
\text { Compliance with this requirement is demonstrated by a } \\
\text { program for documenting and the existence of records that } \\
\text { document the process for acquiring and verifying the } \\
\text { validity of low-level waste characterization data acquired } \\
\text { through the use of direct or indirect methods. }\end{array}$ & $\begin{array}{l}\text { Characterization is addressed in MCP-17000 } § 4.3 \text {. } \\
\text { LLW currently is not being generated in this facility. } \\
\text { In the case generation does occur, generator } \\
\text { requirements to establish a new waste generating } \\
\text { activity are addressed in LWP-8000, with generator } \\
\text { responsibilities found in LWP-17000. }\end{array}$ \\
\hline $\begin{array}{l}\text { (1) Data Quality Objectives. The data quality objectives } \\
\text { process, or a comparable process, shall be used for } \\
\text { identifying characterization parameters and acceptable } \\
\text { uncertainty in characterization data. } \\
\text { From DOE G 435.1-1 Chapter IV: } \\
\text { Compliance with this requirement is demonstrated by the } \\
\text { documented use of a data quality objectives or a comparable } \\
\text { process for determining the type, quantity, and quality of } \\
\text { characterization data needed to safely manage low-level } \\
\text { waste. }\end{array}$ & $\begin{array}{l}\text { Radioactive waste management facilities characterize } \\
\text { waste in accordance with the requirements of the } \\
\text { receiving storage, treatment, or disposal facility. The } \\
\text { documented use of a data quality objectives process, } \\
\text { or comparable process, was not identified for this } \\
\text { facility. }\end{array}$ \\
\hline
\end{tabular}


Table 4. (continued).

\begin{tabular}{|c|c|}
\hline \multicolumn{2}{|c|}{ Facility Name: TRA-621, Nuclear Materials Inspection and Storage Facility } \\
\hline Chapter IV, LLW Requirements & Facility Compliance Information \\
\hline $\begin{array}{l}\text { (2) Minimum Waste Characterization. Characterization data } \\
\text { shall, at a minimum, include the following information } \\
\text { relevant to the management of the waste: } \\
\text { From DOE G 435.1-1 Chapter IV: } \\
\text { Compliance with this requirement is demonstrated by the } \\
\text { existence of a program or procedure for determining and } \\
\text { records that document characterization of low-level waste } \\
\text { consistent with the minimum characterization data } \\
\text { requirements.) }\end{array}$ & Characterization is addressed in MCP-17000 $§ 4.3$. \\
\hline (a) Physical and chemical characteristics; & $\begin{array}{l}\text { MCP-17000, including } \S \S 4.2,4.3 \text {, and } 4.4 \text {, addresses } \\
\text { waste characterization. Information on physical and } \\
\text { chemical characteristics is generally required. }\end{array}$ \\
\hline $\begin{array}{l}\text { (b) Volume, including the waste and any stabilization or } \\
\text { absorbent media; }\end{array}$ & $\begin{array}{l}\text { MCP-17000 } \S 4.2 \text { requires generator information on } \\
\text { the volume of waste expected to be generated. } \\
\text { Information on absorbent media is required in } \S \S 4.5 \\
\text { and } 4.7 \text {. }\end{array}$ \\
\hline (c) Weight of the container and contents; & $\begin{array}{l}\text { MCP-17000 } \$ 4.7 .8 \text { requires weight information if } \\
\text { waste from different generators is being consolidated } \\
\text { into one container. This is not the case in TRA- } 621 .\end{array}$ \\
\hline $\begin{array}{l}\text { (d) Identities, activities, and concentrations of major } \\
\text { radionuclides; }\end{array}$ & $\begin{array}{l}\text { MCP-17000, including } \S \S 4.2,4.3 \text {, and } 4.4 \text {, addresses } \\
\text { waste characterization. Information on major } \\
\text { radionuclides is generally required. }\end{array}$ \\
\hline (e) Characterization date; & $\begin{array}{l}\text { MCP-17000 generally requires the date that a form is } \\
\text { signed or an entry is made into a log or IWTS to be } \\
\text { captured. The date that the characterization is } \\
\text { performed is not explicitly required to be captured. }\end{array}$ \\
\hline (f) Generating source; and & $\begin{array}{l}\text { Regarding the routine solid LLW streams generated } \\
\text { subsequent to operations, MCP-17000, including } \\
\S \S 4.2,4.3 \text {, and } 4.4, \text { addresses waste characterization. } \\
\text { Information on the generating source is generally } \\
\text { required. }\end{array}$ \\
\hline $\begin{array}{l}\text { (g) Any other information which may be needed to prepare } \\
\text { and maintain the disposal facility performance assessment, } \\
\text { or demonstrate compliance with applicable performance } \\
\text { objectives. }\end{array}$ & $\begin{array}{l}\text { MCP-17000 does not specifically describe } \\
\text { information needed to address disposal facility } \\
\text { performance assessment and performance objectives. }\end{array}$ \\
\hline $\begin{array}{l}\text { J. Waste Certification. A waste certification program shall } \\
\text { be developed, documented, and implemented to ensure that } \\
\text { the waste acceptance requirements of facilities receiving } \\
\text { low-level waste for storage, treatment, and disposal are met. }\end{array}$ & $\begin{array}{l}\text { MCP-17000 cites a waste certification program for } \\
\text { LLW destined for NNSS. A waste certification } \\
\text { program for other storage, treatment, or disposal } \\
\text { facilities is not addressed. }\end{array}$ \\
\hline $\begin{array}{l}\text { From DOE G } 435.1-1 \text { Chapter IV: } \\
\text { Compliance with the development and documentation } \\
\text { portion of the certification requirement is demonstrated by a } \\
\text { waste certification plan that identifies the organizations } \\
\text { involved, assigns responsibilities for implementing the }\end{array}$ & $\begin{array}{l}\text { MCP-17500 provides the WGS waste certification } \\
\text { program for LLW to be shipped to NNSS. } \\
\text { Procurement controls do not appear to be addressed. } \\
\text { Also, how the procedure is maintained within the } \\
\text { site's document control system is not addressed in the } \\
\text { procedure and has not been determined. }\end{array}$ \\
\hline
\end{tabular}


Table 4. (continued).

\begin{tabular}{|c|c|}
\hline \multicolumn{2}{|c|}{ Facility Name: TRA-621, Nuclear Materials Inspection and Storage Facility } \\
\hline Chapter IV, LLW Requirements & Facility Compliance Information \\
\hline $\begin{array}{l}\text { program, and describes or references the quality assurance, } \\
\text { training, procurement controls, records management, and } \\
\text { procedures to be used by the program. Acceptable } \\
\text { performance for implementing the program is demonstrated } \\
\text { when appropriate personnel are trained and follow the } \\
\text { procedures that govern their part of the waste certification. } \\
\text { Additionally, acceptable performance is demonstrated if the } \\
\text { waste certification plan and procedures are current and } \\
\text { controlled in accordance with a document controls program, } \\
\text { and records related to certification (e.g., certification } \\
\text { statements, training records, procurement records, } \\
\text { characterization records, container records) are generated } \\
\text { and managed in accordance with the established site } \\
\text { program. }\end{array}$ & \\
\hline $\begin{array}{l}\text { (1) Certification Program. The waste certification program } \\
\text { shall designate the officials who have the authority to certify } \\
\text { and release waste for shipment; and specify what } \\
\text { documentation is required for waste generation, } \\
\text { characterization, shipment, and certification. The program } \\
\text { shall provide requirements for auditability, retrievability, } \\
\text { and storage of required documentation and specify the } \\
\text { records retention period. }\end{array}$ & $\begin{array}{l}\text { MCP- } 17500 \S \S 2 \text { and } 5 \text { identify which specific } \\
\text { records of certification must be obtained and } \\
\text { maintained. }\end{array}$ \\
\hline From DOE G 435.1-1 Chapter IV: & \\
\hline $\begin{array}{l}\text { Compliance with this requirement is demonstrated by a } \\
\text { program or procedure for record keeping and records } \\
\text { showing that low-level waste is certified as having met the } \\
\text { waste acceptance criteria of the facility to which it was } \\
\text { transferred and that the certification statement is supported } \\
\text { by additional records regarding the waste source, } \\
\text { characterization, and container. }\end{array}$ & \\
\hline $\begin{array}{l}\text { (2) Certification before Transfer. Low-level waste shall be } \\
\text { certified as meeting waste acceptance requirements before it } \\
\text { is transferred to the facility receiving the waste. }\end{array}$ & $\begin{array}{l}\text { MCP-17500 } § 4.3 .6 \text { provides the controls for } \\
\text { certification prior to transfer for LLW destined for } \\
\text { disposition at NNSS. }\end{array}$ \\
\hline From DOE G 435.1-1 Chapter IV: & \\
\hline $\begin{array}{l}\text { Compliance with this requirement is demonstrated by the } \\
\text { presence of a certification program which includes } \\
\text { procedures requiring a signed certification statement prior to } \\
\text { the release of waste for transfer, and by dated records } \\
\text { showing that waste was certified before being transferred. }\end{array}$ & \\
\hline $\begin{array}{l}\text { (3) Maintaining Certification. Low-level waste that has been } \\
\text { certified as meeting the waste acceptance requirements for } \\
\text { transfer to a storage, treatment, or disposal facility shall be } \\
\text { managed in a manner that maintains its certification status. }\end{array}$ & $\begin{array}{l}\text { MCP-17500 does not appear to address this } \\
\text { requirement. }\end{array}$ \\
\hline From DOE G 435.1-1 Chapter IV: & \\
\hline $\begin{array}{l}\text { Compliance with this requirement is demonstrated by a } \\
\text { program or procedure reflecting this requirement is present } \\
\text { and site personnel are able to show that the storage of low- }\end{array}$ & \\
\hline
\end{tabular}


Table 4. (continued).

\begin{tabular}{|c|c|}
\hline \multicolumn{2}{|c|}{ Facility Name: TRA-621, Nuclear Materials Inspection and Storage Facility } \\
\hline Chapter IV, LLW Requirements & Facility Compliance Information \\
\hline $\begin{array}{l}\text { level waste containers is in a facility or manner where the } \\
\text { containers would not be damaged by normal weather events, } \\
\text { and cannot be accessed by unauthorized personnel. Further, } \\
\text { each container can be traced to its certification and the } \\
\text { information supporting that certification. }\end{array}$ & \\
\hline $\begin{array}{l}\text { K. Waste Transfer. A documented process shall be } \\
\text { established and implemented for transferring responsibility } \\
\text { for management of low-level waste and for ensuring } \\
\text { availability of relevant data. The following requirements are } \\
\text { in addition to those in Chapter I of this Manual. }\end{array}$ & $\begin{array}{l}\text { WGS manages certification of waste generated at } \\
\text { INL (MCP-17000 } 1.1) \text {. }\end{array}$ \\
\hline From DOE G 435.1-1 Chapter IV: & \\
\hline $\begin{array}{l}\text { Compliance with this requirement is demonstrated if } \\
\text { facilities have procedures for the receipt of waste and the } \\
\text { transfer of waste, as appropriate, which address the } \\
\text { acquisition of waste and container data and the transfer of } \\
\text { ownership, respectively. Further evidence of acceptable } \\
\text { performance is facility records showing that data on the } \\
\text { waste containers is available and accurate, and that } \\
\text { documented transfer of responsibility occurs. }\end{array}$ & \\
\hline $\begin{array}{l}\text { (1) Authorization. Low-level waste shall not be transferred } \\
\text { to a storage, treatment, or disposal facility until personnel } \\
\text { responsible for the facility receiving the waste authorize the } \\
\text { transfer. }\end{array}$ & See K. above. \\
\hline From DOE G 435.1-1 Chapter IV: & \\
\hline $\begin{array}{l}\text { Compliance with this requirement is demonstrated by sites } \\
\text { having procedures that require a confirmation of } \\
\text { authorization before releasing waste for transfer, and records } \\
\text { showing that transfers are made in accordance with written } \\
\text { authorizations. }\end{array}$ & \\
\hline $\begin{array}{l}\text { (2) Data. Waste characterization data, container information, } \\
\text { and generation, storage, treatment, and transportation } \\
\text { information for low-level waste shall be transferred with or } \\
\text { be traceable to the waste. }\end{array}$ & See K. above. \\
\hline $\begin{array}{l}\text { Compliance with this requirement is demonstrated if there } \\
\text { are procedures requiring that characterization and container } \\
\text { data be provided and maintained for each low-level waste } \\
\text { transfer and documented records of transfers show that the } \\
\text { information is being provided. }\end{array}$ & \\
\hline $\begin{array}{l}\text { L. Packaging and Transportation. The following } \\
\text { requirements are in addition to those in Chapter I of this } \\
\text { Manual [DOE M 435.1-1 §I.1.E(11)]. }\end{array}$ & $\begin{array}{l}\text { Not a facility-specific requirement. DOE Manual } \\
\text { 435.1-1 §I.1.E(11) applies to field element managers. }\end{array}$ \\
\hline
\end{tabular}


Table 4. (continued).

\begin{tabular}{|c|c|}
\hline \multicolumn{2}{|c|}{ Facility Name: TRA-621, Nuclear Materials Inspection and Storage Facility } \\
\hline Chapter IV, LLW Requirements & Facility Compliance Information \\
\hline $\begin{array}{l}\text { (1) Packaging. If containers are used: } \\
\text { From DOE G 435.1-1 Chapter IV: } \\
\text { Compliance with the packaging requirement is } \\
\text { demonstrated by: (1) procedures which document proper } \\
\text { packaging protocols; and (2) no trends of routine } \\
\text { repackaging of low-level waste that is packaged after } \\
\text { issuance of DOE O } 435.1 \text {. Successful performance of this } \\
\text { requirement is also demonstrated by a record of containers } \\
\text { for which failure has not routinely occurred under } \\
\text { management conditions. It is recognized that there may be } \\
\text { failed containers for waste previously placed in storage. For } \\
\text { those containers, the goal is to only have to repackage the } \\
\text { waste one time after it is retrieved and characterized. } \\
\text { Further, acceptable performance is demonstrated by } \\
\text { containers of waste having marking and labeling that allows } \\
\text { correlation with waste characterization data and container } \\
\text { information.) }\end{array}$ & MCP-17000 $\S 4$ addresses packaging requirements. \\
\hline $\begin{array}{l}\text { (a) Low-level waste shall be packaged in a manner that } \\
\text { provides containment and protection for the duration of the } \\
\text { anticipated storage period and until disposal is achieved or } \\
\text { until the waste has been removed from the container. }\end{array}$ & See (1) above. \\
\hline $\begin{array}{l}\text { (b) When waste is packaged, vents or other measures shall } \\
\text { be provided if the potential exists for pressurizing or } \\
\text { generating flammable or explosive concentrations of gases } \\
\text { within the waste container. }\end{array}$ & See (1) above. \\
\hline $\begin{array}{l}\text { (c) Containers of low-level waste shall be marked such that } \\
\text { their contents can be identified. }\end{array}$ & See (1) above. \\
\hline $\begin{array}{l}\text { (2) Transportation. To the extent practical, the volume of } \\
\text { waste and number of low-level waste shipments shall be } \\
\text { minimized. } \\
\text { From DOE G } 435.1-1 \text { Chapter IV: } \\
\text { Compliance with this requirement can be demonstrated by a } \\
\text { combination of site procedures directing the efficient use of } \\
\text { waste container capacity and documentation showing that } \\
\text { low-level waste shipments are systematically planned and } \\
\text { optimized to the extent practical. }\end{array}$ & $\begin{array}{l}\text { MCP-17000 } \$ 4 \text { addresses transportation. The waste } \\
\text { disposition specialist coordinates with packaging and } \\
\text { transportation personnel for waste shipped offsite } \\
\text { from this facility. }\end{array}$ \\
\hline $\begin{array}{l}\text { M. Site Evaluation and Facility Design. The following } \\
\text { requirements are in addition to those in Chapter I of this } \\
\text { Manual. }\end{array}$ & $\begin{array}{l}\text { NA; this requirement addresses new radioactive } \\
\text { waste management facilities. }\end{array}$ \\
\hline $\begin{array}{l}\text { (1) Site Evaluation. Proposed locations for low-level waste } \\
\text { facilities shall be evaluated to identify relevant features that } \\
\text { should be avoided or must be considered in facility design } \\
\text { and analyses. }\end{array}$ & See M. above. \\
\hline $\begin{array}{l}\text { (a) Each site proposed for a new low-level waste facility or } \\
\text { expansion of an existing low-level waste facility shall be }\end{array}$ & See M. above. \\
\hline
\end{tabular}


Table 4. (continued).

\begin{tabular}{|c|c|}
\hline \multicolumn{2}{|c|}{ Facility Name: TRA-621, Nuclear Materials Inspection and Storage Facility } \\
\hline Chapter IV, LLW Requirements & Facility Compliance Information \\
\hline $\begin{array}{l}\text { evaluated considering environmental characteristics, } \\
\text { geotechnical characteristics, and human activities, including } \\
\text { for a low-level waste disposal facility, the capability of the } \\
\text { site to demonstrate, at a minimum, whether it is: }\end{array}$ & \\
\hline $\begin{array}{l}1 \text { Located to accommodate the projected volume of waste to } \\
\text { be received; }\end{array}$ & See M. above. \\
\hline $\begin{array}{l}2 \text { Located in a flood plain, a tectonically active area, or in } \\
\text { the zone of water table fluctuation; and }\end{array}$ & See M. above. \\
\hline $\begin{array}{l}3 \text { Located where radionuclide migration pathways are } \\
\text { predictable and erosion and surface runoff can be controlled. }\end{array}$ & See M. above. \\
\hline $\begin{array}{l}\text { (b) Proposed sites with environmental characteristics, } \\
\text { geotechnical characteristics, and human activities for which } \\
\text { adequate protection cannot be provided through facility } \\
\text { design shall be deemed unsuitable for the location of the } \\
\text { facility. }\end{array}$ & See M. above. \\
\hline $\begin{array}{l}\text { (c) Low-level waste disposal facilities shall be sited to } \\
\text { achieve long-term stability and to minimize, to the extent } \\
\text { practical, the need for active maintenance following final } \\
\text { closure. }\end{array}$ & See M. above. \\
\hline $\begin{array}{l}\text { (2) Low-Level Waste Treatment and Storage Facility } \\
\text { Design. The following facility requirements and general } \\
\text { design criteria, at a minimum, apply: }\end{array}$ & See M. above. \\
\hline $\begin{array}{l}\text { (a) Confinement. Low-level waste systems and components } \\
\text { shall be designed to maintain waste confinement. }\end{array}$ & See M. above. \\
\hline (b) Ventilation. & See M. above. \\
\hline $\begin{array}{l}1 \text { Design of low-level waste treatment and storage facilities } \\
\text { shall include ventilation, if applicable, through an } \\
\text { appropriate filtration system to maintain the release of } \\
\text { radioactive material in airborne effluents within the } \\
\text { requirements and guidelines specified in applicable } \\
\text { requirements. }\end{array}$ & See M. above. \\
\hline $\begin{array}{l}2 \text { When conditions exist for generating gases in flammable } \\
\text { or explosive concentrations, ventilation systems or other } \\
\text { measures shall be provided to keep the gases in a non- } \\
\text { flammable and nonexplosive condition. Where } \\
\text { concentrations of explosive or flammable gases are expected } \\
\text { to approach the lower flammability limit, measures shall be } \\
\text { taken to prevent deflagration or detonation. }\end{array}$ & See M. above. \\
\hline $\begin{array}{l}\text { (c) Consideration of Decontamination and } \\
\text { Decommissioning. Areas in new and modifications to } \\
\text { existing low-level waste management facilities that are } \\
\text { subject to contamination with radioactive or other hazardous } \\
\text { materials shall be designed to facilitate decontamination. } \\
\text { For such facilities a proposed decommissioning method or a } \\
\text { conversion method leading to reuse shall be described. }\end{array}$ & See M. above. \\
\hline
\end{tabular}


Table 4. (continued).

\begin{tabular}{|c|c|}
\hline \multicolumn{2}{|c|}{ Facility Name: TRA-621, Nuclear Materials Inspection and Storage Facility } \\
\hline Chapter IV, LLW Requirements & Facility Compliance Information \\
\hline $\begin{array}{l}\text { (d) Instrumentation and Control Systems. Engineering } \\
\text { controls shall be incorporated in the design and engineering } \\
\text { of low-level waste treatment and storage facilities to provide } \\
\text { volume inventory data and to prevent spills, leaks, and } \\
\text { overflows from tanks or confinement systems. }\end{array}$ & See M. above. \\
\hline $\begin{array}{l}\text { (e) Monitoring. Monitoring and/or leak detection } \\
\text { capabilities shall be incorporated in the design and } \\
\text { engineering of low-level waste treatment and storage } \\
\text { facilities to provide rapid identification of failed } \\
\text { confinement and/or other abnormal conditions. }\end{array}$ & See M. above. \\
\hline $\begin{array}{l}\text { (3) Low-Level Waste Disposal Facility Design. The } \\
\text { following facility requirements and general design criteria, } \\
\text { at a minimum, apply: }\end{array}$ & See M. above. \\
\hline $\begin{array}{l}\text { (a) Confinement. Low-level waste systems and components } \\
\text { shall be designed to maintain waste confinement. }\end{array}$ & See M. above. \\
\hline (b) Ventilation. & See M. above. \\
\hline $\begin{array}{l}1 \text { Design of low-level waste disposal facilities shall include } \\
\text { ventilation, if applicable, through an appropriate filtration } \\
\text { system to maintain the release of radioactive material in } \\
\text { airborne effluents within the requirements and guidelines } \\
\text { specified in applicable requirements. }\end{array}$ & See M. above. \\
\hline $\begin{array}{l}2 \text { When conditions exist for generating gases in flammable } \\
\text { or explosive concentrations, ventilation systems or other } \\
\text { measures shall be provided to keep the gases in a non- } \\
\text { flammable and non-explosive condition. Where } \\
\text { concentrations of explosive or flammable gases are expected } \\
\text { to approach the lower flammability limit, measures shall be } \\
\text { taken to prevent deflagration or detonation. }\end{array}$ & See M. above. \\
\hline $\begin{array}{l}\text { (c) Stability. Low-level waste disposal facilities shall be } \\
\text { designed to achieve long-term stability and to minimize to } \\
\text { the extent practical, the need for active maintenance } \\
\text { following final closure. }\end{array}$ & See M. above. \\
\hline $\begin{array}{l}\text { (d) Control of Water. Low-level waste disposal facilities } \\
\text { shall be designed to minimize to the extent practical, the } \\
\text { contact of waste with water during and after disposal. }\end{array}$ & See M. above. \\
\hline $\begin{array}{l}\text { N. Storage and Staging. The following requirements are in } \\
\text { addition to those in Chapter I of this Manual [DOE M } \\
\text { 435.1-1 §I.2.F(13)]. }\end{array}$ & $\begin{array}{l}\text { Not a facility-specific requirement. DOE Manual } \\
435.1-1 \S I .2 . \mathrm{F}(13) \text { applies to field element managers. }\end{array}$ \\
\hline $\begin{array}{l}\text { (1) Storage Prohibitions. Low-level waste in storage shall } \\
\text { not be readily capable of detonation, explosive } \\
\text { decomposition, reaction at anticipated pressures and } \\
\text { temperatures, or explosive reaction with water. Prior to } \\
\text { storage, pyrophoric materials shall be treated, prepared, and } \\
\text { packaged to be nonflammable. } \\
\text { From DOE G 435.1-1 Chapter IV: }\end{array}$ & $\begin{array}{l}\text { NA; this facility does not store LLW. See N. (7) } \\
\text { below for staging requirements. }\end{array}$ \\
\hline
\end{tabular}


Table 4. (continued).

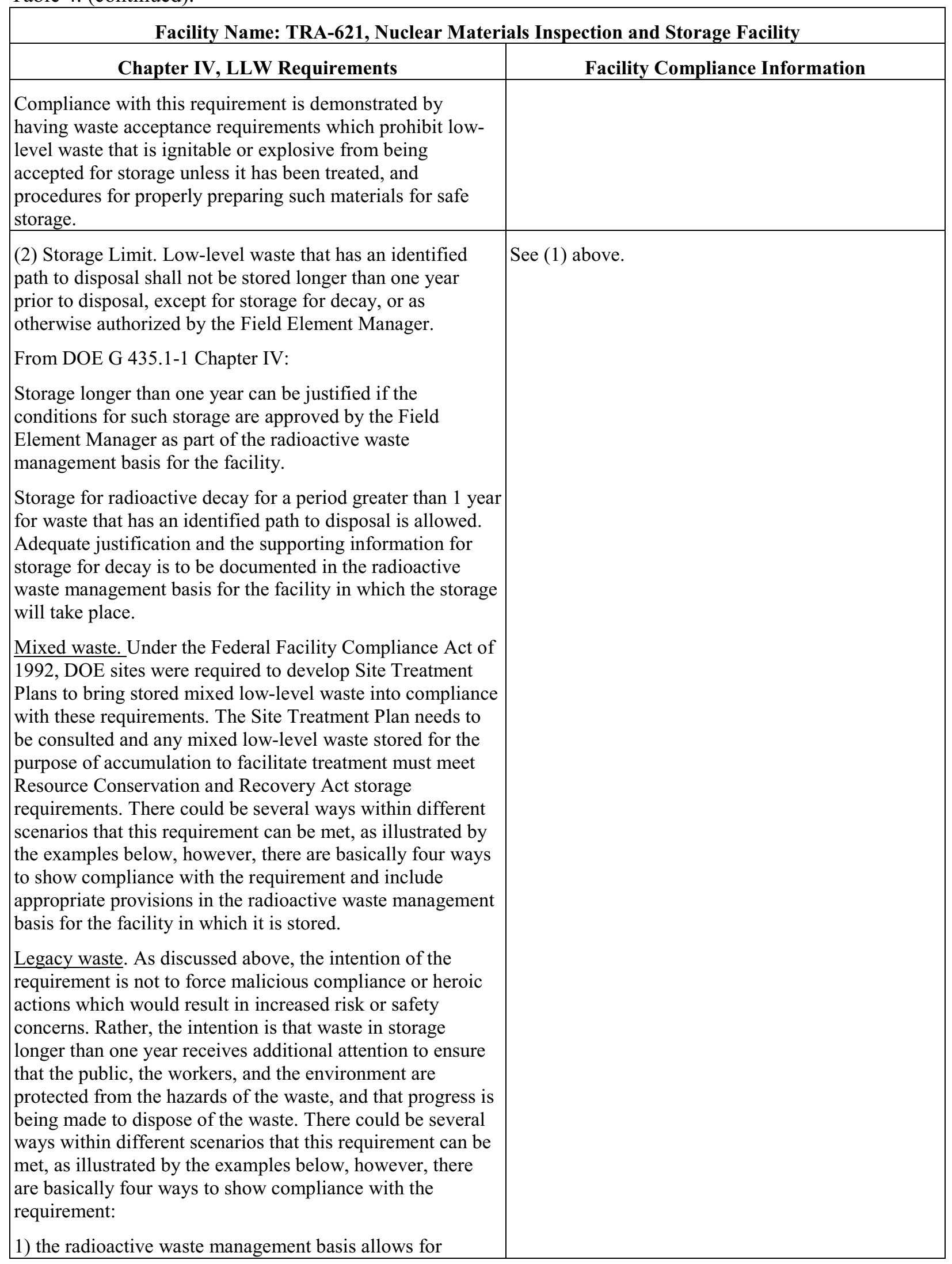


Table 4. (continued).

\begin{tabular}{|c|c|}
\hline \multicolumn{2}{|c|}{ Facility Name: TRA-621, Nuclear Materials Inspection and Storage Facility } \\
\hline Chapter IV, LLW Requirements & Facility Compliance Information \\
\hline storage for no more than one year. & \\
\hline $\begin{array}{l}\text { 2) the radioactive waste management basis allows for } \\
\text { storage for no more than one year, or for storage for decay } \\
\text { only for periods greater than a year, which are specified on a } \\
\text { radionuclide basis. }\end{array}$ & \\
\hline $\begin{array}{l}\text { 3) the radioactive waste management basis allows for } \\
\text { storage for more than one year, up to a specified period of } \\
\text { time based on a documented technical evaluation that the } \\
\text { waste can be stored in a manner that does not cause changes } \\
\text { to the waste or waste packages that is detrimental to the safe } \\
\text { storage of the waste, the final disposal of the waste or to } \\
\text { meeting the disposal performance objectives. }\end{array}$ & \\
\hline $\begin{array}{l}\text { 4) the radioactive waste management basis allows for } \\
\text { storage for decay (with specifics) and for storage for more } \\
\text { than one year for other low-level waste, up to a specified } \\
\text { period of time based on a documented technical evaluation } \\
\text { that the waste can be stored in a manner that does not cause } \\
\text { changes to the waste or waste packages that is detrimental to } \\
\text { the safe storage of the waste, the final disposal of the waste } \\
\text { or to meeting the disposal performance objectives. }\end{array}$ & \\
\hline $\begin{array}{l}\text { Compliance with this requirement is demonstrated by the } \\
\text { existence of a radioactive waste management basis for the } \\
\text { storage facility approved by the Field Element Manager that } \\
\text { includes the time frames that waste are allowed to be stored, } \\
\text { the necessary justifications for storage for decay, and the } \\
\text { necessary technical evaluations if storage is to extend } \\
\text { significantly beyond the one-year time frame. }\end{array}$ & \\
\hline $\begin{array}{l}\text { (3) Storage Integrity. Low-level waste shall be stored in a } \\
\text { location and manner that protects the integrity of waste for } \\
\text { the expected time of storage and minimizes worker } \\
\text { exposure. }\end{array}$ & See (1) above. \\
\hline $\begin{array}{l}\text { However, in making a decision to use a facility for storage } \\
\text { and in developing a radioactive waste management basis for } \\
\text { the activity, particular attention to protection of workers is } \\
\text { needed. }\end{array}$ & \\
\hline From DOE G 435.1-1 Chapter IV: & \\
\hline $\begin{array}{l}\text { Compliance with this requirement is demonstrated if sites } \\
\text { have storage capabilities for low-level waste that provide } \\
\text { protection to waste containers so that their integrity will not } \\
\text { be damaged through physical or chemical (corrosion) } \\
\text { processes and that keep personnel from spending extended } \\
\text { periods of time in the areas where low-level waste is stored. }\end{array}$ & \\
\hline (4) Waste Characterization for Storage. & See (1) above. \\
\hline $\begin{array}{l}\text { (a) Low-level waste that does not have an identified path to } \\
\text { disposal shall be characterized as necessary to meet the data } \\
\text { quality objectives and minimum characterization }\end{array}$ & See (1) above. \\
\hline
\end{tabular}


Table 4. (continued).

\begin{tabular}{|c|c|}
\hline \multicolumn{2}{|c|}{ Facility Name: TRA-621, Nuclear Materials Inspection and Storage Facility } \\
\hline Chapter IV, LLW Requirements & Facility Compliance Information \\
\hline $\begin{array}{l}\text { requirements of this Chapter, to ensure safe storage, and to } \\
\text { facilitate disposal. }\end{array}$ & \\
\hline $\begin{array}{l}\text { (b) Characterization information for all low-level waste in } \\
\text { storage shall be maintained as a record in accordance with } \\
\text { the requirements for Records Management in Chapter I of } \\
\text { this Manual. }\end{array}$ & See (1) above. \\
\hline From DOE G 435.1-1 Chapter IV: & \\
\hline $\begin{array}{l}\text { Compliance with this requirement is demonstrated by } \\
\text { documented procedures for managing waste characterization } \\
\text { and container information on low-level waste as a Federal } \\
\text { record. The records are managed per the applicable policies } \\
\text { and procedures for records management referenced in DOE } \\
\text { O } 200.1 \text { and established at the applicable Field Element. }\end{array}$ & \\
\hline $\begin{array}{l}\text { (5) Container Inspection. A process shall be developed and } \\
\text { implemented for inspecting and maintaining containers of } \\
\text { low-level waste to ensure container integrity is not } \\
\text { compromised. }\end{array}$ & $\begin{array}{l}\text { LI-435 requires quarterly inspections of radioactive } \\
\text { waste containers if waste is stored outdoors or has } \\
\text { been in storage for greater than } 1 \text { year. }\end{array}$ \\
\hline From DOE G 435.1-1 Chapter IV: & \\
\hline $\begin{array}{l}\text { Compliance with this requirement is demonstrated by: (1) a } \\
\text { documented process for waste container inspection and } \\
\text { maintenance; and (2) documentation for all waste container } \\
\text { inspections and maintenance actions performed. }\end{array}$ & \\
\hline $\begin{array}{l}\text { (6) Storage Management. Low-level waste storage shall be } \\
\text { managed to identify and segregate low-level waste from } \\
\text { mixed low-level waste. }\end{array}$ & See (1) above. \\
\hline $\begin{array}{l}\text { (7) Staging. Staging of low-level waste shall be for the } \\
\text { purpose of the accumulation of such quantities of waste as } \\
\text { necessary to facilitate transportation, treatment, and } \\
\text { disposal. Staging longer than } 90 \text { days shall meet the } \\
\text { requirements for storage above and in Chapter I of this } \\
\text { Manual. }\end{array}$ & $\begin{array}{l}\text { Routine LLW, such as personnel protective } \\
\text { equipment, is accumulated at this facility for } \\
\text { disposal. MCP-17000, Appendix F, "Container Start } \\
\text { Date and Storage Prohibitions," restricts staging } \\
\text { LLW to } 90 \text { days maximum at any generator or } \\
\text { treatment facility prior to acceptance by a storage } \\
\text { facility. }\end{array}$ \\
\hline & As stated in DOF Guide $4351-1$ SIV N (7) staging \\
\hline $\begin{array}{l}\text { The staging of low-level waste needs to be addressed in the } \\
\text { radioactive waste management basis for the facility that is } \\
\text { performing the staging. Generators, treatment facilities, and } \\
\text { disposal facilities that stage waste must ensure that the } \\
\text { action of staging is included and authorized as part of their } \\
\text { radioactive waste management basis for the affected } \\
\text { facilities, operations, or activities. }\end{array}$ & $\begin{array}{l}\text { As stated in DOE Guide } 435.1-1 \text { IV.N.( } 7) \text {, staging } \\
\text { waste in accordance with this requirement allows } \\
\text { waste to be accumulated without being considered } \\
\text { storage and being bound by the associated storage } \\
\text { requirements. }\end{array}$ \\
\hline $\begin{array}{l}\text { Staging longer than } 90 \text { days must be justified, the conditions } \\
\text { for such storage met, and these practices approved by the } \\
\text { Field Element Manager as part of the radioactive waste } \\
\text { management basis for the facility. }\end{array}$ & \\
\hline $\begin{array}{l}\text { Compliance with this requirement is demonstrated by a } \\
\text { staging program that limits the temporary storage of waste }\end{array}$ & \\
\hline
\end{tabular}


Table 4. (continued).

Facility Name: TRA-621, Nuclear Materials Inspection and Storage Facility

\begin{tabular}{l} 
Chapter IV, LLW Requirements \\
\hline to only circumstances allowed in the requirement, including \\
justifications for any staging that exceeds the 90-day period, \\
which is documented in the radioactive waste management \\
basis for the facility.
\end{tabular}

O. Treatment. Low-level waste treatment to provide more stable waste forms and to improve the long-term

performance of a low-level waste disposal facility shall be implemented as necessary to meet the performance objectives of the disposal facility.

From DOE G 435.1-1 Chapter IV:

Compliance with this requirement is demonstrated when a treatment facility or process ensures that treated waste will meet the minimum waste form requirements of DOE M 435.1 and meet additional disposal facility-specific waste acceptance requirements for additional stability or long-term performance of facilities that will receive the treated waste.

P. Disposal. Low-level waste disposal facilities shall meet the following requirements.

(1) Performance Objectives. Low-level waste disposal facilities shall be sited, designed, operated, maintained, and closed so that a reasonable expectation exists that the following performance objectives will be met for waste disposed of after September 26, 1988:

(a) Dose to representative members of the public shall not exceed $25 \mathrm{mrem}(0.25 \mathrm{mSv})$ in a year total effective dose equivalent from all exposure pathways, excluding the dose from radon and its progeny in air.

(b) Dose to representative members of the public via the air pathway shall not exceed $10 \mathrm{mrem}(0.10 \mathrm{mSv})$ in a year total effective dose equivalent, excluding the dose from radon and its progeny.

(c) Release of radon shall be less than an average flux of 20 See P. above $\mathrm{pCi} / \mathrm{m}^{2} / \mathrm{s}\left(0.74 \mathrm{~Bq} / \mathrm{m}^{2} / \mathrm{s}\right)$ at the surface of the disposal facility. Alternatively, a limit of $0.5 \mathrm{pCi} / 1(0.0185 \mathrm{~Bq} / \mathrm{l})$ of air may be applied at the boundary of the facility.

(2) Performance Assessment. A site-specific radiological performance assessment shall be prepared and maintained for DOE low-level waste disposed of after September 26, 1988. The performance assessment shall include calculations for a 1,000 year period after closure of potential doses to representative future members of the public and potential releases from the facility to provide a reasonable expectation that the performance objectives identified in this Chapter are not exceeded as a result of operation and closure of the facility.

(a) Analyses performed to demonstrate compliance with the See P. above Facility Compliance Information

NA; this facility is not a LLW treatment facility.

NA; this facility is not a LLW disposal facility.

See P. above

See P. above

See P. above

See P. above 
Table 4. (continued).

\begin{tabular}{|c|c|}
\hline \multicolumn{2}{|c|}{ Facility Name: TRA-621, Nuclear Materials Inspection and Storage Facility } \\
\hline Chapter IV, LLW Requirements & Facility Compliance Information \\
\hline $\begin{array}{l}\text { performance objectives in this Chapter, and to establish } \\
\text { limits on concentrations of radionuclides for disposal based } \\
\text { on the performance measures for inadvertent intruders in } \\
\text { this Chapter shall be based on reasonable activities in the } \\
\text { critical group of exposed individuals. Unless otherwise } \\
\text { specified, the assumption of average living habits and } \\
\text { exposure conditions in representative critical groups of } \\
\text { individuals projected to receive the highest doses is } \\
\text { appropriate. The likelihood of inadvertent intruder scenarios } \\
\text { may be considered in interpreting the results of the analyses } \\
\text { and establishing radionuclide concentrations, if adequate } \\
\text { justification is provided. }\end{array}$ & \\
\hline $\begin{array}{l}\text { (b) The point of compliance shall correspond to the point of } \\
\text { highest projected dose or concentration beyond a } 100 \text { meter } \\
\text { buffer zone surrounding the disposed waste. A larger or } \\
\text { smaller buffer zone may be used if adequate justification is } \\
\text { provided. }\end{array}$ & See P. above \\
\hline $\begin{array}{l}\text { (c) Performance assessments shall address reasonably } \\
\text { foreseeable natural processes that might disrupt barriers } \\
\text { against release and transport of radioactive materials. }\end{array}$ & See P. above \\
\hline $\begin{array}{l}\text { (d) Performance assessments shall use DOE-approved dose } \\
\text { coefficients (dose conversion factors) for internal and } \\
\text { external exposure of reference adults. }\end{array}$ & See P. above \\
\hline $\begin{array}{l}\text { (e) The performance assessment shall include a } \\
\text { sensitivity/uncertainty analysis. }\end{array}$ & See P. above \\
\hline $\begin{array}{l}\text { (f) Performance assessments shall include a demonstration } \\
\text { that projected releases of radionuclides to the environment } \\
\text { shall be maintained as low as reasonably achievable } \\
\text { (ALARA). }\end{array}$ & See P. above. \\
\hline $\begin{array}{l}\text { (g) For purposes of establishing limits on radionuclides that } \\
\text { may be disposed of near-surface, the performance } \\
\text { assessment shall include an assessment of impacts to water } \\
\text { resources. }\end{array}$ & See P. above \\
\hline $\begin{array}{l}\text { (h) For purposes of establishing limits on the concentration } \\
\text { of radionuclides that may be disposed of near-surface, the } \\
\text { performance assessment shall include an assessment of } \\
\text { impacts calculated for a hypothetical person assumed to } \\
\text { inadvertently intrude for a temporary period into the low- } \\
\text { level waste disposal facility. For intruder analyses, } \\
\text { institutional controls shall be assumed to be effective in } \\
\text { deterring intrusion for at least } 100 \text { years following closure. } \\
\text { The intruder analyses shall use performance measures for } \\
\text { chronic and acute exposure scenarios, respectively, of } 100 \\
\text { mrem ( } 1 \mathrm{mSv}) \text { in a year and } 500 \text { mrem }(5 \mathrm{mSv}) \text { total } \\
\text { effective dose equivalent excluding radon in air. }\end{array}$ & See P. above \\
\hline $\begin{array}{l}\text { (3) Composite Analysis. For disposal facilities which } \\
\text { received waste after September } 26,1988 \text {, a site-specific } \\
\text { radiological composite analysis shall be prepared and }\end{array}$ & See P. above \\
\hline
\end{tabular}


Table 4. (continued).

\begin{tabular}{|c|c|}
\hline \multicolumn{2}{|c|}{ Facility Name: TRA-621, Nuclear Materials Inspection and Storage Facility } \\
\hline Chapter IV, LLW Requirements & Facility Compliance Information \\
\hline $\begin{array}{l}\text { maintained that accounts for all sources of radioactive } \\
\text { material that may be left at the DOE site and may interact } \\
\text { with the low- level waste disposal facility, contributing to } \\
\text { the dose projected to a hypothetical member of the public } \\
\text { from the existing or future disposal facilities. Performance } \\
\text { measures shall be consistent with DOE requirements for } \\
\text { protection of the public and environment and evaluated for a } \\
1,000 \text { year period following disposal facility closure. The } \\
\text { composite analysis results shall be used for planning, } \\
\text { radiation protection activities, and future use commitments } \\
\text { to minimize the likelihood that current low- level waste } \\
\text { disposal activities will result in the need for future corrective } \\
\text { or remedial actions to adequately protect the public and the } \\
\text { environment. }\end{array}$ & \\
\hline $\begin{array}{l}\text { (4) Performance Assessment and Composite Analysis } \\
\text { Maintenance. The performance assessment and composite } \\
\text { analysis shall be maintained to evaluate changes that could } \\
\text { affect the performance, design, and operating bases for the } \\
\text { facility. Performance assessment and composite analysis } \\
\text { maintenance shall include the conduct of research, field } \\
\text { studies, and monitoring needed to address uncertainties or } \\
\text { gaps in existing data. The performance assessment shall be } \\
\text { updated to support the final facility closure. Additional } \\
\text { iterations of the performance assessment and composite } \\
\text { analysis shall be conducted as necessary during the post- } \\
\text { closure period. }\end{array}$ & See P. above \\
\hline $\begin{array}{l}\text { (a) Performance assessments and composite analyses shall } \\
\text { be reviewed and revised when changes in waste forms or } \\
\text { containers, radionuclide inventories, facility design and } \\
\text { operations, closure concepts, or the improved understanding } \\
\text { of the performance of the waste disposal facility in } \\
\text { combination with the features of the site on which it is } \\
\text { located alter the conclusions or the conceptual model(s) of } \\
\text { the existing performance assessment or composite analysis. }\end{array}$ & See P. above \\
\hline $\begin{array}{l}\text { (b) A determination of the continued adequacy of the } \\
\text { performance assessment and composite analysis shall be } \\
\text { made on an annual basis, and shall consider the results of } \\
\text { data collection and analysis from research, field studies, and } \\
\text { monitoring. }\end{array}$ & See P. above \\
\hline $\begin{array}{l}\text { (c) Annual summaries of low-level waste disposal } \\
\text { operations shall be prepared with respect to the conclusions } \\
\text { and recommendations of the performance assessment and } \\
\text { composite analysis and a determination of the need to revise } \\
\text { the performance assessment or composite analysis. }\end{array}$ & See P. above \\
\hline $\begin{array}{l}\text { (5) Disposal Authorization. A disposal authorization } \\
\text { statement shall be obtained prior to construction of a new } \\
\text { low-level waste disposal facility. Field Elements with } \\
\text { existing low-level waste disposal facilities shall obtain a } \\
\text { disposal authorization statement in accordance with the }\end{array}$ & See P. above \\
\hline
\end{tabular}


Table 4. (continued).

\begin{tabular}{|c|c|}
\hline \multicolumn{2}{|c|}{ Facility Name: TRA-621, Nuclear Materials Inspection and Storage Facility } \\
\hline Chapter IV, LLW Requirements & Facility Compliance Information \\
\hline $\begin{array}{l}\text { schedule in the Complex-Wide Low-Level Waste } \\
\text { Management Program Plan. The disposal authorization } \\
\text { statement shall be issued based on a review of the facility's } \\
\text { performance assessment, composite analysis, performance } \\
\text { assessment and composite analysis maintenance, } \\
\text { preliminary closure plan, and preliminary monitoring plan. } \\
\text { The disposal authorization statement shall specify the limits } \\
\text { and conditions on construction, design, operations, and } \\
\text { closure of the low-level waste facility based on these } \\
\text { reviews. A disposal authorization statement is a part of the } \\
\text { radioactive waste management basis for a disposal facility. } \\
\text { Failure to obtain a disposal authorization statement by the } \\
\text { implementation date of this Order shall result in shutdown } \\
\text { of the disposal facility. }\end{array}$ & \\
\hline $\begin{array}{l}\text { (6) Disposal Facility Operations. The disposal facility } \\
\text { design and operation must be consistent with the disposal } \\
\text { facility closure plan and lead to disposal facility closure that } \\
\text { provides a reasonable expectation that performance } \\
\text { objectives will be met. Low-level waste shall be disposed in } \\
\text { such a manner that achieves the performance objectives } \\
\text { stated in this Chapter, consistent with the disposal facility } \\
\text { radiological performance assessment. Additional } \\
\text { requirements include: }\end{array}$ & See P. above \\
\hline $\begin{array}{l}\text { (a) Operating procedures shall be developed and } \\
\text { implemented for low-level waste disposal facilities that } \\
\text { protect the public, workers, and the environment; ensure the } \\
\text { security of the facility; minimize subsidence during and } \\
\text { after waste emplacement; achieve long-term stability and } \\
\text { minimize the need for long-term active maintenance; and } \\
\text { meet the requirements of the closure/post-closure plan. }\end{array}$ & See P. above \\
\hline $\begin{array}{l}\text { (b) Permanent identification markers for disposal } \\
\text { excavations and monitoring wells shall be emplaced. }\end{array}$ & See P. above \\
\hline $\begin{array}{l}\text { (c) Low-level waste placement into disposal units shall } \\
\text { minimize voids between waste containers. Voids within } \\
\text { disposal units shall be filled to the extent practical. } \\
\text { Uncontainerized bulk waste shall also be placed in a manner } \\
\text { that minimizes voids and subsidence. }\end{array}$ & See P. above \\
\hline $\begin{array}{l}\text { (d) Operations are to be conducted so that active waste } \\
\text { disposal operations will not have an adverse effect on any } \\
\text { other disposal units. }\end{array}$ & See P. above. \\
\hline $\begin{array}{l}\text { (e) Operations shall include a process for tracking and } \\
\text { documenting low-level waste placement in the facility by } \\
\text { generator source. }\end{array}$ & See P. above. \\
\hline $\begin{array}{l}\text { (7) Alternate Requirements for Low-Level Waste Disposal } \\
\text { Facility Design and Operation. Requirements other than } \\
\text { those set forth in this Section for the design and operation of } \\
\text { a low-level waste disposal facility may be approved on a } \\
\text { specific basis if a reasonable expectation is demonstrated }\end{array}$ & See P. above. \\
\hline
\end{tabular}


Table 4. (continued).

\begin{tabular}{|c|c|}
\hline \multicolumn{2}{|c|}{ Facility Name: TRA-621, Nuclear Materials Inspection and Storage Facility } \\
\hline Chapter IV, LLW Requirements & Facility Compliance Information \\
\hline that the disposal performance objectives will be met. & \\
\hline $\begin{array}{l}\text { Q. Closure. The following requirements are in addition to } \\
\text { those in Chapter I of this Manual. }\end{array}$ & See (1) below. \\
\hline $\begin{array}{l}\text { (1) Disposal Facility Closure Plans. A preliminary closure } \\
\text { plan shall be developed and submitted to Headquarters for } \\
\text { review with the performance assessment and composite } \\
\text { analysis. The closure plan shall be updated following } \\
\text { issuance of the disposal authorization statement to } \\
\text { incorporate conditions specified in the disposal } \\
\text { authorization statement. Closure plans shall: }\end{array}$ & NA; this facility is not a LLW disposal facility. \\
\hline $\begin{array}{l}\text { (a) Be updated as required during the operational life of the } \\
\text { facility. }\end{array}$ & See (1) above. \\
\hline $\begin{array}{l}\text { (b) Include a description of how the disposal facility will be } \\
\text { closed to achieve long-term stability and minimize the need } \\
\text { for active maintenance following closure and to ensure } \\
\text { compliance with the requirements of DOE 5400.5, } \\
\text { Radiation Protection of the Public and the Environment. }\end{array}$ & See (1) above. \\
\hline $\begin{array}{l}\text { (c) Include the total expected inventory of wastes to be } \\
\text { disposed of at the facility over the operational life of the } \\
\text { facility. }\end{array}$ & See (1) above. \\
\hline $\begin{array}{l}\text { (2) Disposal Facility Closure. Closure of a disposal facility } \\
\text { shall occur within a five-year period after it is filled to } \\
\text { capacity, or after the facility is otherwise determined to be } \\
\text { no longer needed. }\end{array}$ & NA; this facility is not a LLW disposal facility. \\
\hline $\begin{array}{l}\text { (a) Prior to facility closure, the final inventory of the low- } \\
\text { level waste disposed in the facility shall be prepared and } \\
\text { incorporated in the performance assessment and composite } \\
\text { analysis which shall be updated to support the closure of the } \\
\text { facility. }\end{array}$ & See (2) above. \\
\hline $\begin{array}{l}\text { (b) A final closure plan shall be prepared based on the final } \\
\text { inventory of waste disposed in the facility, the plan } \\
\text { implemented, and the updated performance assessment and } \\
\text { composite analysis prepared in support of the facility } \\
\text { closure. }\end{array}$ & See (2) above. \\
\hline $\begin{array}{l}\text { (c) Institutional control measures shall be integrated into } \\
\text { land use and stewardship plans and programs, and shall } \\
\text { continue until the facility can be released pursuant to DOE } \\
5400.5, \text { Radiation Protection of the Public and the } \\
\text { Environment. }\end{array}$ & See (2) above. \\
\hline $\begin{array}{l}\text { (d) The location and use of the facility shall be filed with the } \\
\text { local authorities responsible for land use and zoning. }\end{array}$ & See (2) above. \\
\hline $\begin{array}{l}\text { R. Monitoring. The following requirements are in addition } \\
\text { to those in Chapter I of this Manual [DOE M 435.1-1 } \\
\S \text { I.1.E(7)]. }\end{array}$ & $\begin{array}{l}\text { Not a facility-specific requirement. DOE Manual } \\
435.1-1 \text { §I.1.E(7) applies to field element managers. }\end{array}$ \\
\hline $\begin{array}{l}\text { (1) All Waste Facilities. Parameters that shall be sampled or } \\
\text { monitored, at a minimum, include: temperature, pressure }\end{array}$ & $\begin{array}{l}\text { Monitoring requirements at INL radioactive waste } \\
\text { management facilities are tailored for the specific }\end{array}$ \\
\hline
\end{tabular}


Table 4. (continued).

Facility Name: TRA-621, Nuclear Materials Inspection and Storage Facility

Chapter IV, LLW Requirements

(for closed systems), radioactivity in ventilation exhaust and liquid effluent streams, and flammable or explosive mixtures of gases. Facility monitoring programs shall include verification that passive and active control systems have not failed.

From DOE G 435.1-1 Chapter IV:

The minimum parameters specified in the requirement were selected based on their potential significance for anticipating and identifying undesirable conditions at low-level waste management facilities. Each facility's radioactive waste management basis should include an evaluation of the applicability and significance of the minimum parameters. This evaluation also needs to consider additional parameters to be sampled or monitored to ensure the protection of the public health, the environment, and the workers. If a minimum parameter specified in the requirement is deemed to be not applicable in any way to the active operation of that facility, then that justification should be included in the radioactive waste management basis and when approved constitutes an exemption to the manual.

Verification activities are part of the radioactive waste management basis as a condition for operation and documented appropriately.

Compliance with this requirement is demonstrated if monitoring or sampling for the stated parameters is performed for all facilities with a precision, accuracy, and frequency consistent with timely identification of developing problems and a justification exists in the approved radioactive waste management basis for those specified parameters which are not monitored or sampled.

(2) Liquid Waste Storage Facilities. For facilities storing liquid low-level waste, the following shall also be monitored: liquid level and/or waste volume, and significant waste chemistry parameters.

(3) Disposal Facilities. A preliminary monitoring plan for a low-level waste disposal facility shall be prepared and submitted to Headquarters for review with the performance assessment and composite analysis. The monitoring plan shall be updated within one year following issuance of the disposal authorization statement to incorporate and implement conditions specified in the disposal authorization statement.

(a) The site-specific performance assessment and composite See (3) above. analysis shall be used to determine the media, locations, radionuclides, and other substances to be monitored.

(b) The environmental monitoring program shall be designed to include measuring and evaluating releases,
Facility Compliance Information

facility to enable timely indication of developing problems. Existing radiological control procedures and assessments are followed/completed to monitor waste facilities.

LRD-15001 and MCP-139 specify methods and frequency of radiological control surveys of all radiological areas. MCP-139 specifies the use of Form 441.A34. This form is referred to as the "routine sheet" and is to be used by facility radiological control foremen to list radiological areas that are to be surveyed, the survey periods, and methods.

NA; this facility is not a LLW storage facility.

NA; this facility is not a LLW disposal facility.

See (3) above. 
Table 4. (continued).

\begin{tabular}{|l|l|}
\hline \multicolumn{2}{|c|}{ Facility Name: TRA-621, Nuclear Materials Inspection and Storage Facility } \\
\hline \multicolumn{1}{|c|}{ Chapter IV, LLW Requirements } & \multicolumn{1}{|c|}{ Facility Compliance Information } \\
\hline $\begin{array}{l}\text { migration of radionuclides, disposal unit subsidence, and } \\
\text { changes in disposal facility and disposal site parameters } \\
\text { which may affect long-term performance. }\end{array}$ & \\
\hline $\begin{array}{l}\text { (c) The environmental monitoring programs shall be capable } \\
\text { of detecting changing trends in performance to allow } \\
\text { application of any necessary corrective action prior to } \\
\text { exceeding the performance objectives in this Chapter. }\end{array}$ & See (3) above. \\
\hline
\end{tabular}

\subsection{TRA-666, Safety and Tritium Applied Research Facility}

1. Facility description: The STAR facility is a $4,000-\mathrm{ft}^{2}$ laboratory facility that supports fusion safety research involving tritium and molten salts and other research and development activities. Existing experimental systems include steam reactivity; molten salt safety; salt preparation and purification; ion implantation; thermal desorption spectroscopy; and Brunauer, Emmett, and Teller surface examination. Assembly of experiments for use in ATR or other activities for a multi-programmatic laboratory also are conducted in the facility.

2. Hazard category: LTHC3 (radiological)

3. Radioactive waste management activities at this facility: Contact-handled LLW and mixed LLW from routine operations are generated at this facility. The routine contact-handled LLW is accumulated for disposition by WGS. The mixed LLW is accumulated in a satellite accumulation area for disposition.

\section{RWMB documents/programs:}

a) Safety basis/hazards analysis:

- HAD-179, "Safety and Tritium Applied Research Facility"

- EDF-4037, "TRA-666 and TRA-666A STAR Facility, Radiological Control Program Requirements"

b) Laboratory-wide:

- Form 441.A34, "INL Radiological Control Required Surveys"

- LI-435, "Waste Management Routine Field Activities"

- LWP-13840, "Management of Issues, Observations, and Noteworthy Practices"

- LWP-14002, "Timeout and Stop Work Authority"

- LWP-15011, "Radioactive Material Areas and Radioactive Storage Areas"

- LWP-17000, "Waste Management"

- MCP-139, "Radiological Surveys"

- MCP-17000, "Waste Generator Services Waste Management"

- MCP-17410, "Management of Waste Storage Areas"

- MCP-17500, "Waste Generator Services Certification of Waste Shipments to the Nevada Test Site"

- PDD-17000, "Waste Management Program"

- PLN-114, "INL Emergency Plan/RCRA Contingency Plan 
- PLN-522, "Quality Assurance Program Plan for the Waste Management/Waste Certification Program"

c) Facility-specific:

- None.

Table 5 presents the facility compliance information for Chapter IV, "Low-level Waste Requirements."

Table 5. TRA-666, Safety and Tritium Applied Research Facility, DOE Manual 435.1-1 low-level waste requirements and facility compliance information.

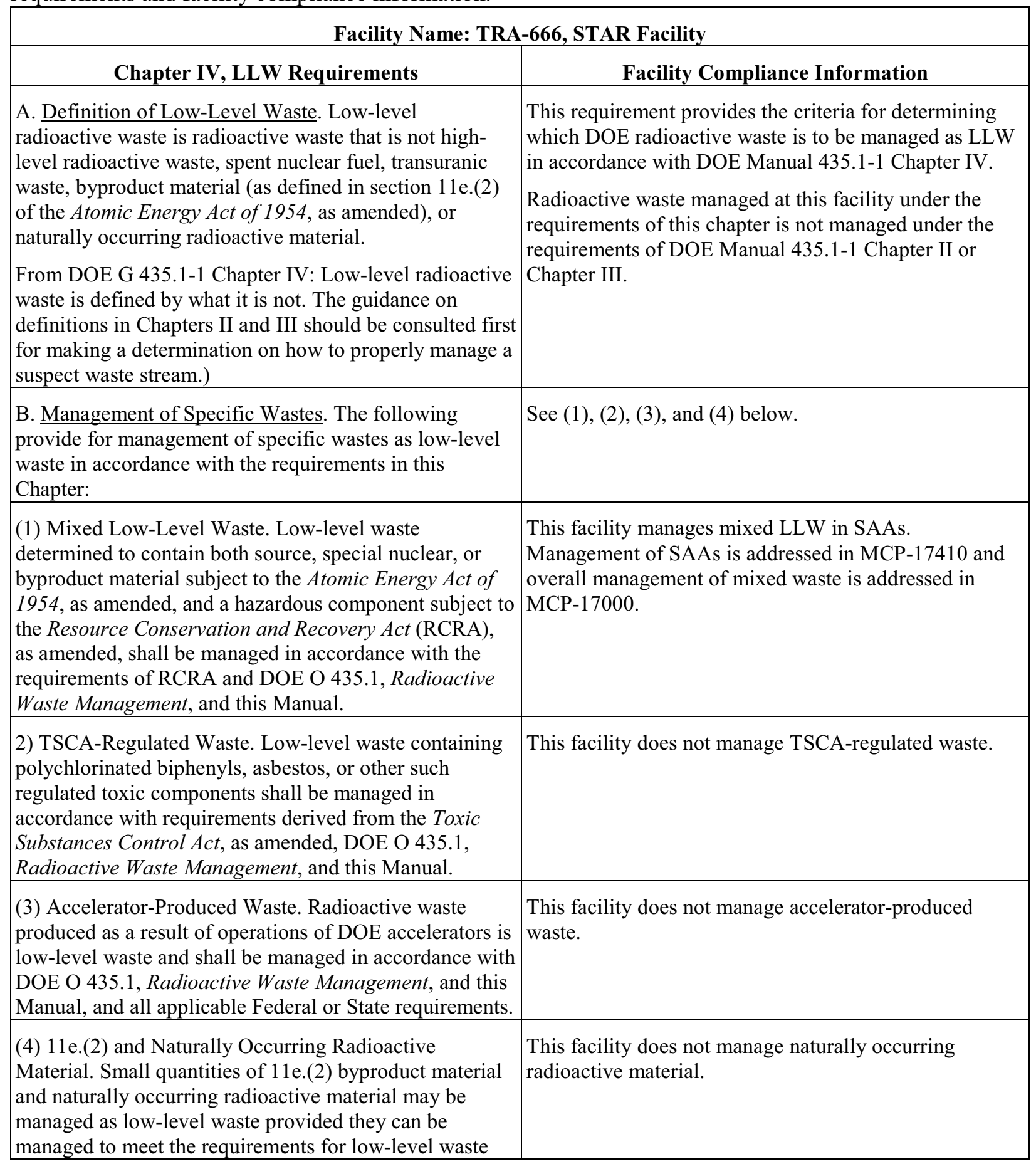


Table 5. (continued).

Facility Name: TRA-666, STAR Facility

\begin{tabular}{|l|}
\hline \multicolumn{1}{|c|}{ Chapter IV, LLW Requirements } \\
\hline disposal in Section IV.P of this Manual. \\
\hline C. Complex-Wide Low-Level Waste Management \\
Program. A complex-wide program and plan shall be \\
developed as described under Responsibilities, 2.B and \\
2.D, in Chapter I of this Manual.
\end{tabular}

D. Radioactive Waste Management Basis. Low-level waste facilities, operations, and activities shall have a radioactive waste management basis consisting of physical and administrative controls to ensure the protection of workers, the public, and the environment. The following specific waste management controls shall be part of the radioactive waste management basis:

DOE Manual 435.1-1 §I.2.B and §I.2.D apply to the Assistant Secretary for Environmental Management and the Deputy Assistant Secretary for Waste Management, respectively.

The information in this table will be used in the development of the RWMB for this facility.

HAD-179 establishes this facility as a LTHC3 radiological facility.

EDF-4037 addresses the necessary radiological controls that are implemented by the ATR Complex Radiological Controls Organization and the R\&D personnel associated with the STAR Facility.

(1) Generators. The waste certification program. See J. below for waste certification program From DOE G 435.1-1 Chapter IV: For a facility that generates low-level waste, the radioactive waste management basis is to include the program for certifying that waste meets the waste acceptance requirements of the facility(ies) to which the waste will be sent.

(2) Treatment Facilities. certification program. The waste acceptance requirements and the waste [sic]

$\mathrm{NA}$; this facility is not a radioactive waste treatment

From DOE G 435.1-1 Chapter IV: Facilities that store or treat low-level waste are to have approved waste acceptance requirements (see DOE M 435.1-1, Section IV.G) prior to the issuance of a radioactive waste management basis.

A facility that stores or treats waste also is generally expected to have a waste certification program. Waste from these facilities will have to be certified as meeting the waste acceptance requirements of the facility to which it will be transferred, and the facilities have the potential for generating radioactive waste (e.g., secondary processing streams from treatment, monitoring and sampling, radioactive release cleanup).

Consequently, storage and treatment facilities should also have an approved waste certification program as part of their radioactive waste management basis.

As part of the radioactive waste management basis, site personnel needs to implement a system or process for tracking the waste inventory at a storage, treatment, or disposal facility.

(3) Storage Facilities. The waste acceptance requirements and the waste certification program. facility.

From DOE G 435.1-1 Chapter IV: Facilities that store or

$\mathrm{NA}$; this facility is not a radioactive waste storage facility. 
Table 5. (continued).

Facility Name: TRA-666, STAR Facility

\begin{tabular}{|c|c|}
\hline Chapter IV, LLW Requirements & Facility Compliance Information \\
\hline $\begin{array}{l}\text { treat low-level waste are to have approved waste } \\
\text { acceptance requirements (see DOE M } 435.1-1 \text {, Section } \\
\text { IV.G) prior to the issuance of a radioactive waste } \\
\text { management basis. }\end{array}$ & \\
\hline $\begin{array}{l}\text { A facility that stores or treats waste also is generally } \\
\text { expected to have a waste certification program. Waste } \\
\text { from these facilities will have to be certified as meeting } \\
\text { the waste acceptance requirements of the facility to } \\
\text { which it will be transferred, and the facilities have the } \\
\text { potential for generating radioactive waste (e.g., } \\
\text { secondary processing streams from treatment, monitoring } \\
\text { and sampling, radioactive release cleanup). } \\
\text { Consequently, storage and treatment facilities should } \\
\text { also have an approved waste certification program as part } \\
\text { of their radioactive waste management basis. }\end{array}$ & \\
\hline $\begin{array}{l}\text { As part of the radioactive waste management basis, site } \\
\text { personnel needs to implement a system or process for } \\
\text { tracking the waste inventory at a storage, treatment, or } \\
\text { disposal facility. }\end{array}$ & \\
\hline $\begin{array}{l}\text { (4) Disposal Facilities. The performance assessment, } \\
\text { composite analysis, disposal authorization statement, } \\
\text { closure plan, waste acceptance requirements, and } \\
\text { monitoring plan. }\end{array}$ & $\begin{array}{l}\text { NA; this facility is not a radioactive waste disposal } \\
\text { facility. }\end{array}$ \\
\hline $\begin{array}{l}\text { E. Contingency Actions. The following requirements are } \\
\text { in addition to those in Chapter I of this Manual [DOE M } \\
435.1-1 \text { II.1.E(5)]. }\end{array}$ & $\begin{array}{l}\text { Not a facility-specific requirement. DOE Manual 435.1- } \\
1 \text { §I.1.E(5) addresses the sitewide emergency } \\
\text { management system. The INL plan is provided in } \\
\text { PLN-114. }\end{array}$ \\
\hline $\begin{array}{l}\text { (1) Contingency Storage. For off-normal or emergency } \\
\text { situations involving high activity or high hazard liquid } \\
\text { low-level waste storage or treatment, spare capacity with } \\
\text { adequate capabilities shall be maintained to receive the } \\
\text { largest volume of liquid contained in any one storage } \\
\text { tank or treatment facility. Tanks or other facilities that } \\
\text { are designated low-level waste contingency storage shall } \\
\text { be maintained in an operational condition when waste is } \\
\text { present and shall meet the requirements of DOE O 435.1, } \\
\text { Radioactive Waste Management, and this Manual. }\end{array}$ & $\begin{array}{l}\text { NA; TRA-666 does not manage liquid LLW waste } \\
\text { streams. }\end{array}$ \\
\hline $\begin{array}{l}\text { From DOE G } 435.1-1 \text { Chapter IV: Compliance with } \\
\text { these requirements is demonstrated if adequate spare } \\
\text { capacity and transfer equipment exists for emergency } \\
\text { transfers of all high activity and high hazard liquid low- } \\
\text { level waste. In addition, the capability to perform } \\
\text { emergency transfers is demonstrated by having waste } \\
\text { transfer routings identified, operational procedures to } \\
\text { direct transfers, staff trained to the procedures, and } \\
\text { records showing that the spare capacity and transfer } \\
\text { capability are kept in operating condition. }\end{array}$ & \\
\hline (2) Transfer Equipment. Pipelines and auxiliary facilities & See (1) al \\
\hline
\end{tabular}


Table 5. (continued).

Facility Name: TRA-666, STAR Facility

\begin{tabular}{|c|c|}
\hline Chapter IV, LLW Requirements & Facility Compliance Information \\
\hline $\begin{array}{l}\text { necessary for the transfer of high activity or high hazard } \\
\text { liquid low-level waste to contingency storage shall be } \\
\text { maintained in an operational condition when waste is } \\
\text { present and shall meet the requirements of DOE O 435.1, } \\
\text { Radioactive Waste Management, and this Manual. } \\
\text { From DOE G 435.1-1 Chapter IV: Compliance with } \\
\text { these requirements is demonstrated if adequate spare } \\
\text { capacity and transfer equipment exists for emergency } \\
\text { transfers of all high activity and high hazard liquid low- } \\
\text { level waste. In addition, the capability to perform } \\
\text { emergency transfers is demonstrated by having waste } \\
\text { transfer routings identified, operational procedures to } \\
\text { direct transfers, staff trained to the procedures, and } \\
\text { records showing that the spare capacity and transfer } \\
\text { capability are kept in operating condition. }\end{array}$ & \\
\hline $\begin{array}{l}\text { F. Corrective Actions. I of this Manual. The following } \\
\text { requirements are in addition to those in Chapter [sic] } \\
\text { From DOE G 435.1-1 Chapter IV: Compliance with } \\
\text { DOE M 435.1-1 §I.2.G.(1) is demonstrated by records } \\
\text { showing what corrective actions were taken to remedy } \\
\text { situations in the radioactive waste management system. } \\
\text { Compliance with DOE M } 435.1-1 \S \text { I.2.G.(2) is } \\
\text { demonstrated by having the necessary procedures, } \\
\text { mechanisms, and training in place to effect shutdown or } \\
\text { curtailment of activities which pose an imminent danger } \\
\text { or other serious hazard to workers or the public, or are } \\
\text { not protective of the environment. }\end{array}$ & $\begin{array}{l}\text { The INL-wide procedure addressing problem } \\
\text { identification as required by DOE Manual 435.1-1 } \\
\text { §I.2.G.(1) is LWP-13840, which implements the } \\
\text { laboratory’s corrective action system. } \\
\text { The INL-wide procedure addressing shutdown or } \\
\text { curtailment of activities as required by DOE } \\
\text { Manual 435.1-1 §I.2.G.(2) is LWP-14002. }\end{array}$ \\
\hline $\begin{array}{l}\text { (1) Order Compliance. Corrective actions shall be } \\
\text { implemented whenever necessary to ensure the } \\
\text { requirements of DOE O } 435.1 \text {, Radioactive Waste } \\
\text { Management, and this Manual are met. }\end{array}$ & See F. above. \\
\hline $\begin{array}{l}\text { From DOE G } 435.1-1 \text { Chapter IV: If a facility or activity } \\
\text { can be allowed to operate while a noncompliant or } \\
\text { hazardous condition exists, the allowance and any } \\
\text { associated limitations must be defined as part of the } \\
\text { facility or activity's radioactive waste management basis, } \\
\text { identified as a configuration controlled item in a } \\
\text { configuration management plan or included in a revision } \\
\text { or modification to an operating procedure or similar } \\
\text { controlled documentation. }\end{array}$ & \\
\hline $\begin{array}{l}\text { Compliance with this requirement is demonstrated if a } \\
\text { corrective action system addresses noncompliant or } \\
\text { hazardous situations involving low-level waste } \\
\text { management facilities in a systematic fashion, and allows } \\
\text { identification of problems by all personnel. }\end{array}$ & \\
\hline $\begin{array}{l}\text { (2) Operations Curtailment. Operations shall be curtailed } \\
\text { or facilities shut down for failure to establish, maintain, }\end{array}$ & $\begin{array}{l}\text { The approved RWMB establishes the current } \\
\text { compliance status at each radioactive waste management }\end{array}$ \\
\hline
\end{tabular}


Table 5. (continued).

Facility Name: TRA-666, STAR Facility

Chapter IV, LLW Requirements

or operate consistent with an approved radioactive waste management basis.

From DOE G 435.1-1 Chapter IV: Compliance with this requirement is demonstrated with a documented system of routine assessments to determine whether waste management activities and facilities are operating in accordance with an approved radioactive waste management basis that provides for graded limitations that can be placed on activities and operations that do not have, or are operating outside of, an approved radioactive waste management basis, including shutdown of the facility.

G. Waste Acceptance. The following requirements are in addition to those in Chapter I of this Manual [DOE M 435.1-1 §I.2.F(6)].

(1) Technical and Administrative. Waste acceptance requirements for all low-level waste storage, treatment, or disposal facilities, operations, and activities shall specify, at a minimum, the following:

From DOE G 435.1-1 Chapter IV: Compliance with these waste acceptance requirements is demonstrated if they are documented, contain clear and precise criteria specifying the radionuclide limits in the form of contents or concentrations that can be accepted, the limitations and prohibitions on waste forms and packages that can be received, and the limits, prohibitions, or instructions concerning any other technical information so that the waste is compatible with the safety basis of the facility, and which will result in acceptable waste at subsequent steps in managing the low-level waste.)

(a) Allowable activities and/or concentrations of specific radionuclides.

(b) Acceptable waste form and/or container requirements that ensure the chemical and physical stability of waste under conditions that might be encountered during transportation, storage, treatment, or disposal.

(c) Restrictions or prohibitions on waste, materials, or containers that may adversely affect waste handlers or compromise facility or waste container performance.

(d) The following are additional waste acceptance requirements that shall be specified in low-level waste disposal facility waste acceptance requirements:

1 Low-level waste must contribute to and not detract from achieving long-term stability of the facility, minimizing the need for long-term active maintenance, minimizing subsidence, and minimizing contact of water with waste. Void spaces within the waste and, if

\section{Facility Compliance Information}

facility. Facility assessments are scheduled to ensure waste management activities are conducted in accordance with the approved RWMB.

Not a facility-specific requirement. DOE Manual 435.11 §I.2.F(6) applies to field element managers.

NA; this facility generates LLW but does not receive any radioactive waste from other sources.
See (1) above.

See (1) above.

See (1) above.

NA; this facility is not a LLW disposal facility. 
Table 5. (continued).

Facility Name: TRA-666, STAR Facility

\begin{tabular}{l} 
Chapter IV, LLW Requirements \\
\hline \multicolumn{1}{|c|}{ containers are used, between the waste and its container } \\
shall be reduced to the extent practical. \\
\hline 2 Liquid low-level waste or low-level waste containing \\
free liquid must be converted into a form that contains as \\
little freestanding liquid as is reasonably achievable, but \\
in no case shall the liquid exceed 1 percent of the waste \\
volume when the low-level waste is in a disposal \\
container, or 0.5 percent of the waste volume after it is \\
processed to a stable form. \\
3 Low-level waste must not be readily capable of \\
detonation or of explosive decomposition or reaction at \\
anticipated pressures and temperatures, or of explosive \\
reaction with water. Pyrophoric materials contained in \\
waste shall be treated, prepared, and packaged to be \\
nonflammable.
\end{tabular}

4 Low-level waste must not contain, or be capable of generating by radiolysis or biodegradation, quantities of toxic gases, vapors, or fumes harmful to the public or workers or disposal facility personnel, or harmful to the long-term structural stability of the disposal site.

5 Low-level waste in a gaseous form must be packaged such that the pressure does not exceed 1.5 atmospheres absolute at $20 \mathrm{C}$. [sic]

(e) The basis, procedures, and levels of authority required for granting exceptions to the waste acceptance requirements, which shall be contained in each facility's waste acceptance documentation. Each exception request shall be documented, including its disposition as approved or not approved.

From DOE G 435.1-1 Chapter IV: Waste acceptance requirements are acceptable if they are documented and contain a clear description of the procedure and bases for obtaining an exception or deviation to the acceptance criteria for low-level waste to be received at the facility.

(2) Evaluation and Acceptance. The receiving facility shall evaluate waste for acceptance, including confirmation that the technical and administrative requirements have been met. A process for the disposition of non-conforming wastes shall be established.

From DOE G 435.1-1 Chapter IV: Compliance with the waste acceptance requirements for a low-level waste management facility is demonstrated if they include a process for evaluation and acceptance of incoming waste to ensure the acceptance criteria of the facility receiving the waste are met that includes one of or a combination of: (1) testing, sampling, and analysis of representative 
Table 5. (continued).

Facility Name: TRA-666, STAR Facility

\begin{tabular}{|l|}
\multicolumn{1}{|c|}{ Chapter IV, LLW Requirements } \\
\hline samples of waste upon receipt; (2) testing, sampling, and \\
analysis of split samples of waste taken at the generator \\
site; (3) evaluation of testing, sampling, and analysis of \\
data provided by the generator, or (4) audits, reviews, \\
surveillance, or observations of generator waste \\
certification programs and characterization activities. \\
Additionally, acceptable waste acceptance requirements \\
for a storage, treatment or disposal facility will have \\
documented procedures and actions to be taken if a waste \\
that does not conform to the waste acceptance criteria is \\
received at the facility.
\end{tabular}

H. Waste Generation Planning. The following requirements are in addition to those in Chapter I of this Manual [DOE M 435.1-1 §I.2.F(7)].

(1) Life-Cycle Planning. Prior to waste generation, planning shall be performed to address the entire life cycle for all low-level waste streams.

From DOE G 435.1-1 Chapter IV: Compliance with this planning requirement is demonstrated by the individual sites establishing a process for evaluating the life-cycle of low-level waste prior to its generation, including the identification of low-level wastes with no path to disposal and appropriate records justifying the newly generated low-level waste stream(s), and site personnel possessing planning information showing the location(s) where low-level waste will be stored, treated, and/or disposed along with a confirmation that the personnel managing the facilities agree that the low-level waste may be managed at those facilities.

(2) Waste with No Identified Path to Disposal. Low-level This facility is not generating radioactive waste that does waste streams with no identified path to disposal shall be not have an identified path to disposal. generated only in accordance with approved conditions which, at a minimum, shall address:

(a) Programmatic need to generate the waste;

See (2) above.

(b) Characteristics and issues preventing the disposal of $\quad$ See (2) above. the waste;

(c) Safe storage of the waste until disposal can be achieved; and

(d) Activities and plans for achieving final disposal of the waste.

I. Waste Characterization. Low-level waste shall be characterized using direct or indirect methods, and the characterization documented in sufficient detail to ensure safe management and compliance with the waste acceptance requirements of the facility receiving the waste.

Not a facility-specific requirement. DOE Manual 435.1-

1 §I.2.F(7) applies to field element managers.

PDD-17000 and LWP-17000 provide direction to the waste generators for waste generation planning to address the entire life cycle.
See (2) above.

See (2) above.

MCP-17000 addresses waste characterization. 
Table 5. (continued).

Facility Name: TRA-666, STAR Facility

\begin{tabular}{|c|}
\hline Chapter IV, LLW Requirements \\
\hline $\begin{array}{l}\text { From DOE G } 435.1-1 \text { Chapter IV: Compliance with this } \\
\text { requirement is demonstrated by a program for } \\
\text { documenting and the existence of records that document } \\
\text { the process for acquiring and verifying the validity of } \\
\text { low-level waste characterization data acquired through } \\
\text { the use of direct or indirect methods. }\end{array}$ \\
\hline $\begin{array}{l}\text { (1) Data Quality Objectives. The data quality objectives } \\
\text { process, or a comparable process, shall be used for } \\
\text { identifying characterization parameters and acceptable } \\
\text { uncertainty in characterization data. }\end{array}$ \\
\hline $\begin{array}{l}\text { From DOE G } 435.1-1 \text { Chapter IV: Compliance with this } \\
\text { requirement is demonstrated by the documented use of a } \\
\text { data quality objectives or a comparable process for } \\
\text { determining the type, quantity, and quality of } \\
\text { characterization data needed to safely manage low-level } \\
\text { waste. }\end{array}$ \\
\hline
\end{tabular}

(2) Minimum Waste Characterization. Characterization data shall, at a minimum, include the following information relevant to the management of the waste:

From DOE G 435.1-1 Chapter IV: Compliance with this requirement is demonstrated by the existence of a program or procedure for determining and records that document characterization of low-level waste consistent with the minimum characterization data requirements.)

(a) Physical and chemical characteristics;

(b) Volume, including the waste and any stabilization or absorbent media;

(c) Weight of the container and contents;

(d) Identities, activities, and concentrations of major radionuclides;

(e) Characterization date;

(f) Generating source; and

(g) Any other information which may be needed to prepare and maintain the disposal facility performance
Facility Compliance Information

Radioactive waste management facilities characterize waste in accordance with the requirements of the receiving storage, treatment, or disposal facility. The documented use of a data quality objectives process, or comparable process, was not identified for this facility.

MCP-17000, including §§ 4.2, 4.3, and 4.4, provides waste characterization requirements. Information on absorbent media is required in $\S \S 4.5$ and 4.7. MCP-17000 also specifies the use of IWTS that documents characterization data in an IWTS profile.

MCP-17000, including $\S \S 4.2,4.3$, and 4.4, addresses waste characterization. Information on physical and chemical characteristics is generally required.

MCP-17000, $\$ 4.2$ requires generator information on the volume of waste expected to be generated. Information on absorbent media is required in $\S \S 4.5$ and 4.7.

MCP-17000, Rev. 1, $\$ 4.7 .8$ requires weight information if waste from different generators is being consolidated into one container. This is not the case in TRA-666.

MCP-17000, including $\S \S 4.2,4.3$, and 4.4, addresses waste characterization. Information on major radionuclides is generally required.

MCP-17000 generally requires the date that a form is signed or an entry is made into a log or IWTS to be captured. The date that characterization is performed is not explicitly required to be captured.

MCP-17000, including $\S \S 4.2,4.3$, and 4.4, addresses waste characterization. Information on the generating source is generally required.

MCP-17000 requires characterization, providing all necessary characterization information. 
Table 5. (continued).

Facility Name: TRA-666, STAR Facility

\begin{tabular}{|l|}
\hline \multicolumn{1}{|c|}{ Chapter IV, LLW Requirements } \\
\hline assessment, or demonstrate compliance with applicable \\
performance objectives. \\
\hline J. Waste Certification. A waste certification program \\
shall be developed, documented, and implemented to \\
ensure that the waste acceptance requirements of \\
facilities receiving low-level waste for storage, treatment, \\
and disposal are met. \\
From DOE G 435.1-1 Chapter IV: Compliance with the \\
development and documentation portion of the \\
certification requirement is demonstrated by a waste \\
certification plan that identifies the organizations \\
involved, assigns responsibilities for implementing the \\
program, and describes or references the quality \\
assurance, training, procurement controls, records \\
management, and procedures to be used by the program. \\
Acceptable performance for implementing the program is \\
demonstrated when appropriate personnel are trained and \\
follow the procedures that govern their part of the waste \\
certification. Additionally, acceptable performance is \\
demonstrated if the waste certification plan and \\
procedures are current and controlled in accordance with \\
a document controls program, and records related to \\
certification (e.g., certification statements, training \\
records, procurement records, characterization records, \\
container records) are generated and managed in \\
accordance with the established site program. \\
\hline
\end{tabular}

(1) Certification Program. The waste certification program shall designate the officials who have the authority to certify and release waste for shipment; and specify what documentation is required for waste generation, characterization, shipment, and certification. The program shall provide requirements for auditability, retrievability, and storage of required documentation and specify the records retention period.

From DOE G 435.1-1 Chapter IV: Compliance with this requirement is demonstrated by a program or procedure for record keeping and records showing that low-level waste is certified as having met the waste acceptance criteria of the facility to which it was transferred and that the certification statement is supported by additional records regarding the waste source, characterization, and container.

(2) Certification before Transfer. Low-level waste shall be certified as meeting waste acceptance requirements before it is transferred to the facility receiving the waste.

From DOE G 435.1-1 Chapter IV: Compliance with this requirement is demonstrated by the presence of a certification program which includes procedures
MCP-17000 cites a waste certification program for LLW destined for NNSS.

MCP-17500 provides the WGS waste certification program for LLW to be shipped to NNSS.

PLN-522 requires waste technical specialists and waste disposition specialists to complete the appropriate training/qualification before being granted approval authority for profiles within the IWTS Program. The waste certification official, alternate waste certification official, and NNSS packaging certifiers must complete the appropriate training/qualifications to disposition waste to NNSS.

See J. above. MCP- $17500 \S \S 2$ and 5 address certification records for shipments to NNSS.

See J. above. MCP- $17500 \S \S 2$ and 5 address certification records for shipments to NNSS. 
Table 5. (continued).

Facility Name: TRA-666, STAR Facility

\begin{tabular}{l} 
Chapter IV, LLW Requirements \\
\hline $\begin{array}{l}\text { requiring a signed certification statement prior to the } \\
\text { release of waste for transfer, and by dated records } \\
\text { showing that waste was certified before being } \\
\text { transferred. }\end{array}$ \\
\hline
\end{tabular}

(3) Maintaining Certification. Low-level waste that has been certified as meeting the waste acceptance requirements for transfer to a storage, treatment, or disposal facility shall be managed in a manner that maintains its certification status.

From DOE G 435.1-1 Chapter IV: Compliance with this requirement is demonstrated by a program or procedure reflecting this requirement is present and site personnel are able to show that the storage of low-level waste containers is in a facility or manner where the containers would not be damaged by normal weather events, and cannot be accessed by unauthorized personnel. Further, each container can be traced to its certification and the information supporting that certification.

K. Waste Transfer. A documented process shall be established and implemented for transferring responsibility for management of low-level waste and for ensuring availability of relevant data. The following requirements are in addition to those in Chapter I of this Manual.

From DOE G 435.1-1 Chapter IV: Compliance with this requirement is demonstrated if facilities have procedures for the receipt of waste and the transfer of waste, as appropriate, which address the acquisition of waste and container data and the transfer of ownership, respectively. Further evidence of acceptable performance is facility records showing that data on the waste containers is available and accurate, and that documented transfer of responsibility occurs.

(1) Authorization. Low-level waste shall not be transferred to a storage, treatment, or disposal facility until personnel responsible for the facility receiving the waste authorize the transfer.

From DOE G 435.1-1 Chapter IV: Compliance with this requirement is demonstrated by sites having procedures that require a confirmation of authorization before releasing waste for transfer, and records showing that transfers are made in accordance with written authorizations.

(2) Data. Waste characterization data, container information, and generation, storage, treatment, and transportation information for low-level waste shall be transferred with or be traceable to the waste.
See J. above. Pre-certification checklists are cited in MCP-17000 and MCP-17500. Surveillances also are addressed in MCP-17500.

MCP-17000 $§ 4.8 .15$ specifies requirements for interfacility transfers.

MCP-17500 $\$ 4$ addresses LLW to be transferred to NNSS.

See K. above. 
Table 5. (continued).

Facility Name: TRA-666, STAR Facility

\begin{tabular}{|l|}
\hline \multicolumn{1}{|c|}{ Chapter IV, LLW Requirements } \\
\hline $\begin{array}{l}\text { From DOE G 435.1-1 Chapter IV: Compliance with this } \\
\text { requirement is demonstrated if there are procedures } \\
\text { requiring that characterization and container data be } \\
\text { provided and maintained for each low-level waste } \\
\text { transfer and documented records of transfers show that } \\
\text { the information is being provided. }\end{array}$ \\
\hline
\end{tabular}

L. Packaging and Transportation. The following requirements are in addition to those in Chapter I of this Manual [DOE M 435.1-1 §I.1.E(11)].

(1) Packaging. If containers are used:

Not a facility-specific requirement. DOE Manual 435.1-

1 §I.1.E(11) applies to field element managers.

From DOE G 435.1-1 Chapter IV: Compliance with the packaging requirement is demonstrated by: (1) procedures which document proper packaging protocols; and (2) no trends of routine repackaging of low-level waste that is packaged after issuance of DOE O 435.1. Successful performance of this requirement is also demonstrated by a record of containers for which failure has not routinely occurred under management conditions. It is recognized that there may be failed containers for waste previously placed in storage. For those containers, the goal is to only have to repackage the waste one time after it is retrieved and characterized. Further, acceptable performance is demonstrated by containers of waste having marking and labeling that allows correlation with waste characterization data and container information.)

(a) Low-level waste shall be packaged in a manner that provides containment and protection for the duration of the anticipated storage period and until disposal is achieved or until the waste has been removed from the container.

(b) When waste is packaged, vents or other measures shall be provided if the potential exists for pressurizing or generating flammable or explosive concentrations of gases within the waste container.

(c) Containers of low-level waste shall be marked such that their contents can be identified.

(2) Transportation. To the extent practical, the volume of waste and number of low-level waste shipments shall be minimized.

From DOE G 435.1-1 Chapter IV: Compliance with this requirement can be demonstrated by a combination of site procedures directing the efficient use of waste container capacity and documentation showing that lowlevel waste shipments are systematically planned and optimized to the extent practical.

M. Site Evaluation and Facility Design. The following

MCP-17000 $\$ 4$ addresses packaging requirements.

See (1) above.

See (1) above.

See (1) above.

MCP-17000 §4 addresses transportation. The waste disposition specialist coordinates with packaging and transportation personnel for waste shipped offsite from this facility.

NA; this requirement addresses new radioactive waste 
Table 5. (continued).

Facility Name: TRA-666, STAR Facility

Chapter IV, LLW Requirements

requirements are in addition to those in Chapter I of this Manual.

(1) Site Evaluation. Proposed locations for low-level waste facilities shall be evaluated to identify relevant features that should be avoided or must be considered in facility design and analyses.

(a) Each site proposed for a new low-level waste facility or expansion of an existing low-level waste facility shall be evaluated considering environmental characteristics, geotechnical characteristics, and human activities, including for a low-level waste disposal facility, the capability of the site to demonstrate, at a minimum, whether it is:

1 Located to accommodate the projected volume of waste to be received;

2 Located in a flood plain, a tectonically active area, or in the zone of water table fluctuation; and

3 Located where radionuclide migration pathways are predictable and erosion and surface runoff can be controlled.

(b) Proposed sites with environmental characteristics, geotechnical characteristics, and human activities for which adequate protection cannot be provided through facility design shall be deemed unsuitable for the location of the facility.

(c) Low-level waste disposal facilities shall be sited to achieve long-term stability and to minimize, to the extent practical, the need for active maintenance following final closure.

(2) Low-Level Waste Treatment and Storage Facility Design. The following facility requirements and general design criteria, at a minimum, apply:

(a) Confinement. Low-level waste systems and components shall be designed to maintain waste confinement.

\begin{tabular}{|l|l|}
\hline (b) Ventilation. & See M. above. \\
\hline $\begin{array}{l}\text { 1 Design of low-level waste treatment and storage } \\
\text { facilities shall include ventilation, if applicable, through } \\
\text { an appropriate filtration system to maintain the release of } \\
\text { radioactive material in airborne effluents within the } \\
\text { requirements and guidelines specified in applicable } \\
\text { requirements. }\end{array}$ & See M. above. \\
\hline $\begin{array}{l}2 \text { When conditions exist for generating gases in } \\
\text { flammable or explosive concentrations, ventilation } \\
\text { systems or other measures shall be provided to keep the }\end{array}$ & See M. above. \\
\hline
\end{tabular}

Facility Compliance Information

management facilities.

See M. above.

See M. above.

See M. above.

See M. above.

See M. above.

See M. above.

See M. above.

See M. above.

See M. above.

See M. above.

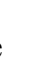


Table 5. (continued).

Facility Name: TRA-666, STAR Facility

gases in a non-flammable and nonexplosive condition. Where concentrations of explosive or flammable gases are expected to approach the lower flammability limit, measures shall be taken to prevent deflagration or detonation.

(c) Consideration of Decontamination and Decommissioning. Areas in new and modifications to existing low-level waste management facilities that are subject to contamination with radioactive or other hazardous materials shall be designed to facilitate decontamination. For such facilities a proposed decommissioning method or a conversion method leading to reuse shall be described.

(d) Instrumentation and Control Systems. Engineering controls shall be incorporated in the design and engineering of low-level waste treatment and storage facilities to provide volume inventory data and to prevent spills, leaks, and overflows from tanks or confinement systems.

(e) Monitoring. Monitoring and/or leak detection capabilities shall be incorporated in the design and engineering of low-level waste treatment and storage facilities to provide rapid identification of failed confinement and/or other abnormal conditions.

(3) Low-Level Waste Disposal Facility Design. The following facility requirements and general design criteria, at a minimum, apply:

(a) Confinement. Low-level waste systems and components shall be designed to maintain waste confinement.

(b) Ventilation.

1 Design of low-level waste disposal facilities shall include ventilation, if applicable, through an appropriate filtration system to maintain the release of radioactive material in airborne effluents within the requirements and guidelines specified in applicable requirements.

2 When conditions exist for generating gases in flammable or explosive concentrations, ventilation systems or other measures shall be provided to keep the gases in a nonflammable and non-explosive condition. Where concentrations of explosive or flammable gases are expected to approach the lower flammability limit, measures shall be taken to prevent deflagration or detonation.

(c) Stability. Low-level waste disposal facilities shall be designed to achieve long-term stability and to minimize to the extent practical, the need for active maintenance following final closure.

See M. above.

See M. above.

See M. above. Facility Compliance Information 
Table 5. (continued).

Facility Name: TRA-666, STAR Facility

Chapter IV, LLW Requirements

(d) Control of Water. Low-level waste disposal facilities shall be designed to minimize to the extent practical, the contact of waste with water during and after disposal.

N. Storage and Staging. The following requirements are in addition to those in Chapter I of this Manual [DOE M 435.1-1 §I.2.F(13)].

(1) Storage Prohibitions. Low-level waste in storage shall not be readily capable of detonation, explosive decomposition, reaction at anticipated pressures and temperatures, or explosive reaction with water. Prior to storage, pyrophoric materials shall be treated, prepared, and packaged to be nonflammable.

From DOE G 435.1-1 Chapter IV: Compliance with this requirement is demonstrated by having waste acceptance requirements which prohibit low-level waste that is ignitable or explosive from being accepted for storage unless it has been treated, and procedures for properly preparing such materials for safe storage.

(2) Storage Limit. Low-level waste that has an identified path to disposal shall not be stored longer than one year prior to disposal, except for storage for decay, or as otherwise authorized by the Field Element Manager.

From DOE G 435.1-1 Chapter IV: Storage longer than one year can be justified if the conditions for such storage are approved by the Field Element Manager as part of the radioactive waste management basis for the facility.

Storage for radioactive decay for a period greater than 1 year for waste that has an identified path to disposal is allowed. Adequate justification and the supporting information for storage for decay is to be documented in the radioactive waste management basis for the facility in which the storage will take place.

Mixed waste. Under the Federal Facility Compliance Act of 1992, DOE sites were required to develop Site

Treatment Plans to bring stored mixed low-level waste into compliance with these requirements. The Site Treatment Plan needs to be consulted and any mixed low-level waste stored for the purpose of accumulation to facilitate treatment must meet Resource Conservation and Recovery Act storage requirements. There could be several ways within different scenarios that this requirement can be met, as illustrated by the examples below, however, there are basically four ways to show compliance with the requirement and include appropriate provisions in the radioactive waste management basis for the facility in which it is stored.
Not a facility-specific requirement. DOE Manual 435.11 §I.2.F(13) applies to field element managers.

NA; this facility does not store LLW. See N. (7) below for staging requirements.

See (1) above.
Facility Compliance Information

See M. above. 
Table 5. (continued).

Facility Name: TRA-666, STAR Facility

\begin{tabular}{l} 
Chapter IV, LLW Requirements \\
\hline Legacy waste. As discussed above, the intention of the \\
requirement is not to force malicious compliance or \\
heroic actions which would result in increased risk or \\
safety concerns. Rather, the intention is that waste in \\
storage longer than one year receives additional attention \\
to ensure that the public, the workers, and the \\
environment are protected from the hazards of the waste, \\
and that progress is being made to dispose of the waste.
\end{tabular}

There could be several ways within different scenarios that this requirement can be met, as illustrated by the examples below, however, there are basically four ways to show compliance with the requirement:

1) the radioactive waste management basis allows for storage for no more than one year.

2) the radioactive waste management basis allows for storage for no more than one year, or for storage for decay only for periods greater than a year, which are specified on a radionuclide basis.

3 ) the radioactive waste management basis allows for storage for more than one year, up to a specified period of time based on a documented technical evaluation that the waste can be stored in a manner that does not cause changes to the waste or waste packages that is detrimental to the safe storage of the waste, the final disposal of the waste or to meeting the disposal performance objectives.

4) the radioactive waste management basis allows for storage for decay (with specifics) and for storage for more than one year for other low-level waste, up to a specified period of time based on a documented technical evaluation that the waste can be stored in a manner that does not cause changes to the waste or waste packages that is detrimental to the safe storage of the waste, the final disposal of the waste or to meeting the disposal performance objectives.

Compliance with this requirement is demonstrated by the existence of a radioactive waste management basis for the storage facility approved by the Field Element Manager that includes the time frames that waste are allowed to be stored, the necessary justifications for storage for decay, and the necessary technical evaluations if storage is to extend significantly beyond the one-year time frame.

(3) Storage Integrity. Low-level waste shall be stored in a See (1) above. location and manner that protects the integrity of waste for the expected time of storage and minimizes worker exposure. 
Table 5. (continued).

Facility Name: TRA-666, STAR Facility

\begin{tabular}{|l|}
\hline \multicolumn{1}{|c|}{ Chapter IV, LLW Requirements } \\
\hline $\begin{array}{l}\text { However, in making a decision to use a facility for } \\
\text { storage and in developing a radioactive waste } \\
\text { management basis for the activity, particular attention to } \\
\text { protection of workers is needed. } \\
\text { From DOE G 435.1-1 Chapter IV: Compliance with this } \\
\text { requirement is demonstrated if sites have storage } \\
\text { capabilities for low-level waste that provide protection to } \\
\text { waste containers so that their integrity will not be } \\
\text { damaged through physical or chemical (corrosion) } \\
\text { processes and that keep personnel from spending } \\
\text { extended periods of time in the areas where low-level } \\
\text { waste is stored. }\end{array}$ \\
\hline
\end{tabular}

(4) Waste Characterization for Storage.

(a) Low-level waste that does not have an identified path See (1) above.

to disposal shall be characterized as necessary to meet

the data quality objectives and minimum characterization

requirements of this Chapter, to ensure safe storage, and to facilitate disposal.

(b) Characterization information for all low-level waste in storage shall be maintained as a record in accordance with the requirements for Records Management in Chapter I of this Manual.

From DOE G 435.1-1 Chapter IV: Compliance with this requirement is demonstrated by documented procedures for managing waste characterization and container information on low-level waste as a Federal record. The records are managed per the applicable policies and procedures for records management referenced in DOE O 200.1 and established at the applicable Field Element.

(5) Container Inspection. A process shall be developed and implemented for inspecting and maintaining containers of low-level waste to ensure container integrity is not compromised.

From DOE G 435.1-1 Chapter IV: Compliance with this requirement is demonstrated by: (1) a documented process for waste container inspection and maintenance; and (2) documentation for all waste container inspections and maintenance actions performed.

(6) Storage Management. Low-level waste storage shall be managed to identify and segregate low-level waste from mixed low-level waste.

(7) Staging. Staging of low-level waste shall be for the purpose of the accumulation of such quantities of waste as necessary to facilitate transportation, treatment, and disposal. Staging longer than 90 days shall meet the requirements for storage above and in Chapter I of this

See (1) above.

LI-435 requires quarterly inspections of radioactive waste containers if waste is stored outdoors or has been in storage for greater than 1 year.
See (1) above.

Routine LLW, such as personnel protective equipment, is accumulated at this facility for disposal. MCP-17000, Appendix F, "Container Start Date and Storage Prohibitions," restricts staging LLW to 90 days maximum at any generator or treatment facility prior to 
Table 5. (continued).

Facility Name: TRA-666, STAR Facility

Manual.

Chapter IV, LLW Requirements

From DOE G 435.1-1 Chapter IV: The staging of low-

level waste needs to be addressed in the radioactive

waste management basis for the facility that is

performing the staging. Generators, treatment facilities,

and disposal facilities that stage waste must ensure that

the action of staging is included and authorized as part of

their radioactive waste management basis for the affected

facilities, operations, or activities.

Staging longer than 90 days must be justified, the conditions for such storage met, and these practices approved by the Field Element Manager as part of the radioactive waste management basis for the facility.

Compliance with this requirement is demonstrated by a staging program that limits the temporary storage of waste to only circumstances allowed in the requirement, including justifications for any staging that exceeds the 90-day period, which is documented in the radioactive waste management basis for the facility.

O. Treatment. Low-level waste treatment to provide more stable waste forms and to improve the long-term performance of a low-level waste disposal facility shall be implemented as necessary to meet the performance objectives of the disposal facility.

From DOE G 435.1-1 Chapter IV: Compliance with this requirement is demonstrated when a treatment facility or process ensures that treated waste will meet the minimum waste form requirements of DOE M 435.1 and meet additional disposal facility-specific waste acceptance requirements for additional stability or longterm performance of facilities that will receive the treated waste.

P. Disposal. Low-level waste disposal facilities shall meet the following requirements.

(1) Performance Objectives. Low-level waste disposal facilities shall be sited, designed, operated, maintained, and closed so that a reasonable expectation exists that the following performance objectives will be met for waste disposed of after September 26, 1988:

(a) Dose to representative members of the public shall not exceed $25 \mathrm{mrem}(0.25 \mathrm{mSv})$ in a year total effective dose equivalent from all exposure pathways, excluding the dose from radon and its progeny in air.

(b) Dose to representative members of the public via the See P. above air pathway shall not exceed $10 \mathrm{mrem}(0.10 \mathrm{mSv})$ in a year total effective dose equivalent, excluding the dose from radon and its progeny.

See P. above

See P. above

Facility Compliance Information acceptance by a storage facility.

As stated in DOE Guide 435.1-1 §IV.N.(7), staging waste in accordance with this requirement allows waste to be accumulated without being considered storage and being bound by the associated storage requirements.

NA; TRA-666 is not a LLW treatment facility.

NA; TRA-666 is not a LLW disposal facility. 
Table 5. (continued).

Facility Name: TRA-666, STAR Facility

\begin{tabular}{|c|}
\hline Chapter IV, LLW Requirements \\
\hline $\begin{array}{l}\text { (c) Release of radon shall be less than an average flux of } \\
20 \mathrm{pCi} / \mathrm{m}^{2} / \mathrm{s}\left(0.74 \mathrm{~Bq} / \mathrm{m}^{2} / \mathrm{s}\right) \text { at the surface of the disposal } \\
\text { facility. Alternatively, a limit of } 0.5 \mathrm{pCi} / 1(0.0185 \mathrm{~Bq} / \mathrm{l}) \\
\text { of air may be applied at the boundary of the facility. }\end{array}$ \\
\hline $\begin{array}{l}\text { (2) Performance Assessment. A site-specific radiological } \\
\text { performance assessment shall be prepared and } \\
\text { maintained for DOE low-level waste disposed of after } \\
\text { September } 26,1988 \text {. The performance assessment shall } \\
\text { include calculations for a } 1,000 \text { year period after closure } \\
\text { of potential doses to representative future members of the } \\
\text { public and potential releases from the facility to provide } \\
\text { a reasonable expectation that the performance objectives } \\
\text { identified in this Chapter are not exceeded as a result of } \\
\text { operation and closure of the facility. }\end{array}$ \\
\hline
\end{tabular}

(a) Analyses performed to demonstrate compliance with the performance objectives in this Chapter, and to establish limits on concentrations of radionuclides for disposal based on the performance measures for inadvertent intruders in this Chapter shall be based on reasonable activities in the critical group of exposed individuals. Unless otherwise specified, the assumption of average living habits and exposure conditions in representative critical groups of individuals projected to receive the highest doses is appropriate. The likelihood of inadvertent intruder scenarios may be considered in interpreting the results of the analyses and establishing radionuclide concentrations, if adequate justification is provided.

(b) The point of compliance shall correspond to the point See P. above of highest projected dose or concentration beyond a 100 meter buffer zone surrounding the disposed waste. A larger or smaller buffer zone may be used if adequate justification is provided.

(c) Performance assessments shall address reasonably foreseeable natural processes that might disrupt barriers against release and transport of radioactive materials.

(d) Performance assessments shall use DOE-approved dose coefficients (dose conversion factors) for internal and external exposure of reference adults.

(e) The performance assessment shall include a sensitivity/uncertainty analysis.

(f) Performance assessments shall include a

See P. above Facility Compliance Information

See P. above

See P. above demonstration that projected releases of radionuclides to the environment shall be maintained as low as reasonably achievable (ALARA).

(g) For purposes of establishing limits on radionuclides

See P. above

See P. above

See P. above

See P. above.

See P. above 
Table 5. (continued).

Facility Name: TRA-666, STAR Facility

\begin{tabular}{|l|l|}
\hline \multicolumn{1}{|c|}{ Chapter IV, LLW Requirements } & Facility Compliance Information \\
\hline $\begin{array}{l}\text { that may be disposed of near-surface, the performance } \\
\text { assessment shall include an assessment of impacts to } \\
\text { water resources. }\end{array}$ & \\
\hline
\end{tabular}

(h) For purposes of establishing limits on the

See P. above concentration of radionuclides that may be disposed of near-surface, the performance assessment shall include an assessment of impacts calculated for a hypothetical person assumed to inadvertently intrude for a temporary period into the low-level waste disposal facility. For intruder analyses, institutional controls shall be assumed to be effective in deterring intrusion for at least 100 years following closure. The intruder analyses shall use performance measures for chronic and acute exposure scenarios, respectively, of $100 \mathrm{mrem}(1 \mathrm{mSv})$ in a year and $500 \mathrm{mrem}(5 \mathrm{mSv})$ total effective dose equivalent excluding radon in air.

(3) Composite Analysis. For disposal facilities which received waste after September 26, 1988, a site-specific radiological composite analysis shall be prepared and maintained that accounts for all sources of radioactive material that may be left at the DOE site and may interact with the low- level waste disposal facility, contributing to the dose projected to a hypothetical member of the public from the existing or future disposal facilities. Performance measures shall be consistent with DOE requirements for protection of the public and environment and evaluated for a 1,000 year period following disposal facility closure. The composite analysis results shall be used for planning, radiation protection activities, and future use commitments to minimize the likelihood that current low- level waste disposal activities will result in the need for future corrective or remedial actions to adequately protect the public and the environment.

(4) Performance Assessment and Composite Analysis Maintenance. The performance assessment and composite analysis shall be maintained to evaluate changes that could affect the performance, design, and operating bases for the facility. Performance assessment and composite analysis maintenance shall include the conduct of research, field studies, and monitoring needed to address uncertainties or gaps in existing data. The performance assessment shall be updated to support the final facility closure. Additional iterations of the performance assessment and composite analysis shall be conducted as necessary during the post-closure period.

\begin{tabular}{|l|l|}
\hline $\begin{array}{l}\text { (a) Performance assessments and composite analyses } \\
\text { shall be reviewed and revised when changes in waste } \\
\text { forms or containers, radionuclide inventories, facility }\end{array}$ & See P. above \\
\hline
\end{tabular}


Table 5. (continued).

Facility Name: TRA-666, STAR Facility

\begin{tabular}{|c|c|}
\hline \multicolumn{2}{|c|}{ 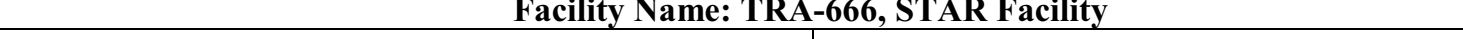 } \\
\hline Chapter IV, LLW Requirements & Facility Compliance Information \\
\hline $\begin{array}{l}\text { design and operations, closure concepts, or the improved } \\
\text { understanding of the performance of the waste disposal } \\
\text { facility in combination with the features of the site on } \\
\text { which it is located alter the conclusions or the conceptual } \\
\text { model(s) of the existing performance assessment or } \\
\text { composite analysis. }\end{array}$ & \\
\hline $\begin{array}{l}\text { (b) A determination of the continued adequacy of the } \\
\text { performance assessment and composite analysis shall be } \\
\text { made on an annual basis, and shall consider the results of } \\
\text { data collection and analysis from research, field studies, } \\
\text { and monitoring. }\end{array}$ & See P. above \\
\hline $\begin{array}{l}\text { (c) Annual summaries of low-level waste disposal } \\
\text { operations shall be prepared with respect to the } \\
\text { conclusions and recommendations of the performance } \\
\text { assessment and composite analysis and a determination } \\
\text { of the need to revise the performance assessment or } \\
\text { composite analysis. }\end{array}$ & See P. above \\
\hline $\begin{array}{l}\text { (5) Disposal Authorization. A disposal authorization } \\
\text { statement shall be obtained prior to construction of a new } \\
\text { low-level waste disposal facility. Field Elements with } \\
\text { existing low-level waste disposal facilities shall obtain a } \\
\text { disposal authorization statement in accordance with the } \\
\text { schedule in the Complex-Wide Low-Level Waste } \\
\text { Management Program Plan. The disposal authorization } \\
\text { statement shall be issued based on a review of the } \\
\text { facility's performance assessment, composite analysis, } \\
\text { performance assessment and composite analysis } \\
\text { maintenance, preliminary closure plan, and preliminary } \\
\text { monitoring plan. The disposal authorization statement } \\
\text { shall specify the limits and conditions on construction, } \\
\text { design, operations, and closure of the low-level waste } \\
\text { facility based on these reviews. A disposal authorization } \\
\text { statement is a part of the radioactive waste management } \\
\text { basis for a disposal facility. Failure to obtain a disposal } \\
\text { authorization statement by the implementation date of } \\
\text { this Order shall result in shutdown of the disposal } \\
\text { facility. }\end{array}$ & \begin{tabular}{|l} 
See P. above \\
$\mid$
\end{tabular} \\
\hline $\begin{array}{l}\text { (6) Disposal Facility Operations. The disposal facility } \\
\text { design and operation must be consistent with the disposal } \\
\text { facility closure plan and lead to disposal facility closure } \\
\text { that provides a reasonable expectation that performance } \\
\text { objectives will be met. Low-level waste shall be disposed } \\
\text { in such a manner that achieves the performance } \\
\text { objectives stated in this Chapter, consistent with the } \\
\text { disposal facility radiological performance assessment. } \\
\text { Additional requirements include: }\end{array}$ & See P. above \\
\hline $\begin{array}{l}\text { (a) Operating procedures shall be developed and } \\
\text { implemented for low-level waste disposal facilities that } \\
\text { protect the public, workers, and the environment; ensure }\end{array}$ & See P. above \\
\hline
\end{tabular}


Table 5. (continued).

Facility Name: TRA-666, STAR Facility

\begin{tabular}{|l|}
\multicolumn{1}{c}{ Facility Name: TRA } \\
\hline \multicolumn{1}{c}{ Chapter IV, LLW Requirements } \\
\hline the security of the facility; minimize subsidence during \\
and after waste emplacement; achieve long-term stability \\
and minimize the need for long-term active maintenance; \\
and meet the requirements of the closure/post-closure \\
plan.
\end{tabular}

(b) Permanent identification markers for disposal excavations and monitoring wells shall be emplaced.

(c) Low-level waste placement into disposal units shall minimize voids between waste containers. Voids within disposal units shall be filled to the extent practical. Uncontainerized bulk waste shall also be placed in a manner that minimizes voids and subsidence.

(d) Operations are to be conducted so that active waste disposal operations will not have an adverse effect on any other disposal units.

(e) Operations shall include a process for tracking and documenting low-level waste placement in the facility by generator source.

(7) Alternate Requirements for Low-Level Waste Disposal Facility Design and Operation. Requirements other than those set forth in this Section for the design and operation of a low-level waste disposal facility may be approved on a specific basis if a reasonable expectation is demonstrated that the disposal performance objectives will be met.

Q. Closure. The following requirements are in addition to See (1) below. those in Chapter I of this Manual.

(1) Disposal Facility Closure Plans. A preliminary closure plan shall be developed and submitted to Headquarters for review with the performance assessment and composite analysis. The closure plan shall be updated following issuance of the disposal authorization statement to incorporate conditions specified in the disposal authorization statement. Closure plans shall:

(a) Be updated as required during the operational life of $\quad$ See (1) above. the facility.

(b) Include a description of how the disposal facility will See (1) above. be closed to achieve long-term stability and minimize the need for active maintenance following closure and to ensure compliance with the requirements of DOE 5400.5, Radiation Protection of the Public and the Environment.

(c) Include the total expected inventory of wastes to be disposed of at the facility over the operational life of the facility.

See P. above.

NA; TRA-666 is not a LLW disposal facility.

See P. above.

See P. above. Facility Compliance Information

See P. above

See P. above 
Table 5. (continued).

Facility Name: TRA-666, STAR Facility

Chapter IV, LLW Requirements

(2) Disposal Facility Closure. Closure of a disposal facility shall occur within a five-year period after it is filled to capacity, or after the facility is otherwise determined to be no longer needed.

(a) Prior to facility closure, the final inventory of the
low-level waste disposed in the facility shall be prepared
and incorporated in the performance assessment and
composite analysis which shall be updated to support the
closure of the facility.

(b) A final closure plan shall be prepared based on the final inventory of waste disposed in the facility, the plan implemented, and the updated performance assessment and composite analysis prepared in support of the facility closure.

(c) Institutional control measures shall be integrated into land use and stewardship plans and programs, and shall continue until the facility can be released pursuant to DOE 5400.5, Radiation Protection of the Public and the Environment.

(d) The location and use of the facility shall be filed with See (2) above. the local authorities responsible for land use and zoning.

R. Monitoring. The following requirements are in addition to those in Chapter I of this Manual [DOE M 435.1-1 §I.1.E(7)].

(1) All Waste Facilities. Parameters that shall be sampled or monitored, at a minimum, include: temperature, pressure (for closed systems), radioactivity in ventilation exhaust and liquid effluent streams, and flammable or explosive mixtures of gases. Facility monitoring programs shall include verification that passive and active control systems have not failed.

From DOE G 435.1-1 Chapter IV: The minimum parameters specified in the requirement were selected based on their potential significance for anticipating and identifying undesirable conditions at low-level waste management facilities. Each facility's radioactive waste management basis should include an evaluation of the applicability and significance of the minimum parameters. This evaluation also needs to consider additional parameters to be sampled or monitored to ensure the protection of the public health, the environment, and the workers. If a minimum parameter specified in the requirement is deemed to be not applicable in any way to the active operation of that facility, then that justification should be included in the radioactive waste management basis and when approved constitutes an exemption to the manual.

Verification activities are part of the radioactive waste
See (2) above.

See (2) above.

See (2) above. Facility Compliance Information

NA; TRA-666 is not a LLW disposal facility.

Not a facility-specific requirement. DOE Manual 435.1-

1 §I.1.E(7) applies to field element managers.

Monitoring requirements at INL radioactive waste management facilities are tailored for the specific facility to enable timely indication of developing problems. Existing radiological control procedures and assessments are followed/completed to monitor waste facilities.

LRD-15001 and MCP-139 specify methods and frequency of radiological control surveys of all radiological areas. MCP-139 specifies the use of Form 441.A34. This form is referred to as the "routine sheet" and is to be used by facility radiological control foremen to list radiological areas that are to be surveyed, the survey periods, and methods. 
Table 5. (continued).

Facility Name: TRA-666, STAR Facility

\begin{tabular}{|c|c|}
\hline Chapter IV, LLW Requirements & Facility Compliance Information \\
\hline $\begin{array}{l}\text { management basis as a condition for operation and } \\
\text { documented appropriately. }\end{array}$ & \\
\hline $\begin{array}{l}\text { Compliance with this requirement is demonstrated if } \\
\text { monitoring or sampling for the stated parameters is } \\
\text { performed for all facilities with a precision, accuracy, } \\
\text { and frequency consistent with timely identification of } \\
\text { developing problems and a justification exists in the } \\
\text { approved radioactive waste management basis for those } \\
\text { specified parameters which are not monitored or } \\
\text { sampled. }\end{array}$ & \\
\hline $\begin{array}{l}\text { (2) Liquid Waste Storage Facilities. For facilities storing } \\
\text { liquid low-level waste, the following shall also be } \\
\text { monitored: liquid level and/or waste volume, and } \\
\text { significant waste chemistry parameters. }\end{array}$ & NA; TRA-666 is not a LLW storage facility. \\
\hline
\end{tabular}

(3) Disposal Facilities. A preliminary monitoring plan for NA; TRA-666 is not a LLW disposal facility. a low-level waste disposal facility shall be prepared and submitted to Headquarters for review with the performance assessment and composite analysis. The monitoring plan shall be updated within one year following issuance of the disposal authorization statement to incorporate and implement conditions specified in the disposal authorization statement.

(a) The site-specific performance assessment and composite analysis shall be used to determine the media, locations, radionuclides, and other substances to be monitored.

(b) The environmental monitoring program shall be designed to include measuring and evaluating releases, migration of radionuclides, disposal unit subsidence, and changes in disposal facility and disposal site parameters which may affect long-term performance.

(c) The environmental monitoring programs shall be capable of detecting changing trends in performance to allow application of any necessary corrective action prior to exceeding the performance objectives in this Chapter.

\subsection{TRA-670, Advanced Test Reactor}

1. Description: The ATR and ancillary systems are housed in the ATR facility. ATR is designed for use in testing advanced nuclear fuel systems and materials. The reactor provides a high neutron flux (up to $1 \times 10^{15} \mathrm{n} / \mathrm{cm}^{2} / \mathrm{s}$ thermal) environment for flux traps that may contain inpile tubes for high-pressure loops or other flux trap irradiation facilities.

In addition to the nine flux traps, space is provided in the neck shim housing and reflector for experiments of various sizes. ATR incorporates several design features unique in test reactor technology that improve experiment performance. These features include the use of flux trapping to provide high thermal neutron populations in the nine irradiation locations; incorporation of special 
shim designs to minimize perturbations to the axial flux symmetry throughout a fuel cycle; and regional power measurement and control to shift power (within limits) in the core lobes, thereby optimizing neutron flux for particular experiments.

Included in the RWMB analysis for this facility is TRA-605, Effluent Processing Facility. The liquid effluent stream from ATR can be transferred from the ATR warm or hot waste tanks to process tanks in TRA-605 for conditioning pending transfer to the Evaporation Pond (TRA-715). The major components of TRA-605 include a WWTF identical to the ATR WWTF, a warm waste feed tank, a hot waste storage tank, and the ancillary equipment.

The ATR ancillary systems are housed in the following buildings:

- $\quad$ TRA-670, ATR Reactor Building (excluding ATR Critical Facility)

- $\quad$ TRA-671, ATR Cooling Tower Pumphouse

- TRA-609, Compressor Building Switchgear and Compressor Room

- $\quad$ TRA-674, Diesel Building

- $\quad$ TRA-608, Demineralizer Building

- TRA-619, Raw Water Pumphouse

- $\quad$ TRA-633, Firewater Pumphouse

- $\quad$ TRA-634, ATR Storage Facility

- $\quad$ TRA-605, Effluent Processing Facility

- $\quad$ TRA-688, Firewater Pumphouse.

Also included in the RWMB analysis for the TRA-670 facility is TRA-1005, ATR Storage Pad. The TRA-1005 storage pad is considered part of TRA-670 in the safety basis documentation.

2. Hazard category: Hazard Category 1 Nuclear Facility

3. Radioactive waste management activities at this facility: Contact-handled liquid LLW and mixed LLW is generated and staged at TRA-670. Remote-handled LLW is generated and stored. The mixed LLW is accumulated in an SAA for disposition.

At TRA-605, contact-handled liquid and solid LLW are generated and staged.

At the TRA-1005, remote-handled legacy TRU waste and remote-handled legacy LLW is stored. (Some incidental contact-handled LLW is being used to fill the container volume in a waste box of some of the remote-handled legacy LLW.)

\section{RWMB documents/programs:}

a) Laboratory-wide:

- SAR-153, "Upgraded Final Safety Analysis Report for the Advanced Test Reactor"

b) Laboratory-wide:

- Form 441.A34, "INL Radiological Control Required Surveys"

- LI-435, "Waste Management Routine Field Activities"

- LRD-15001, "Radiological Control Manual"

- LWP-13840, "Management of Issues"

- LWP-14002, "Timeout and Stop Work Authority"

- LWP-15011, "Radioactive Material Areas and Radioactive Storage Areas"

- LWP-17000, "Waste Management"

- MCP-139, "Radiological Surveys"

- MCP-17000, "Waste Generator Services Waste Management" 
- MCP-17410, "Management of Waste Storage Areas"

- MCP-17500, "Waste Generator Services Certification of Waste Shipments to the Nevada Test Site"

- PDD-17000, "Waste Management Program"

- PLN-114, "INL Emergency Plan/RCRA Contingency Plan"

- PLN-522, "Quality Assurance Program Plan for the Waste Management/Waste Certification Program"

c) Facility-specific:

- OMM-7.11.13.8.1, "TRA-605 Warm Waste Treatment Facility Operation”

- OMM-7.11.13.8.2, "Sampling Warm Waste Treatment system Effluent"

- OMM-7.11.13.8.4, “TRA-605 Effluent Radiation Monitor (ERM) Normal Operation”

- OMM-7.11.13.8.9, “TRA-605 Effluent Radiation Monitor (ERM) System ATR Warm Waste Effluent Grab Sample"

- SD-24.1.3, "ATR Complex Facilities And Site Services Safety Basis Administrative Controls."

TRU waste and LLW are managed at this facility. Table 6 shows the facility compliance information for DOE Manual 435.1-1 Chapter III, "Transuranic Waste Requirements," and Table 7 presents the facility compliance information for Chapter IV, "Low-level Waste Requirements."

Table 6. TRA-670, Advanced Test Reactor, and TRA-1005, Advanced Test Reactor Storage Pad, DOE Manual 435.1-1 transuranic waste requirements and facility compliance information.

\begin{tabular}{|c|c|}
\hline \multicolumn{2}{|c|}{ TRA-670, Advanced Test Reactor, and TRA-1005, Advanced Test Reactor Storage Pad } \\
\hline Chapter III, Transuranic Waste Requirements & Facility Compliance Information \\
\hline $\begin{array}{l}\text { A. Definition of Transuranic Waste. Transuranic waste } \\
\text { is radioactive waste containing more than } 100 \\
\text { nanocuries ( } 3700 \text { becquerels) of alpha-emitting } \\
\text { transuranic isotopes per gram of waste, with half-lives } \\
\text { greater than } 20 \text { years, except for: } \\
\text { (From DOE G } 435.1-1 \text { Chapter III: The determination } \\
\text { of transuranic waste should be made at the time of waste } \\
\text { certification, that is, each time the waste is transferred to } \\
\text { another person or facility.) }\end{array}$ & $\begin{array}{l}\text { This requirement proves the criteria for determining which } \\
\text { DOE radioactive waste is to be managed as TRU waste in } \\
\text { accordance with DOE Manual } 435.1-1 \text {, Chapter III. } \\
\text { See } \mathrm{J} \text {. below. }\end{array}$ \\
\hline (1) High-level radioactive waste; & See A. above. \\
\hline $\begin{array}{l}\text { (2) Waste that the Secretary of Energy has determined, } \\
\text { with the concurrence of the Administrator of the } \\
\text { Environmental Protection Agency, does not need the } \\
\text { degree of isolation required by the } 40 \text { CFR Part } 191 \\
\text { disposal regulations; or }\end{array}$ & See A. above. \\
\hline $\begin{array}{l}\text { (3) Waste that the Nuclear Regulatory Commission has } \\
\text { approved for disposal on a case-by-case basis in } \\
\text { accordance with } 10 \text { CFR Part } 61 \text {. }\end{array}$ & See A. above. \\
\hline $\begin{array}{l}\text { B. Management of Specific Wastes. The following } \\
\text { provide for management of specific wastes as } \\
\text { transuranic waste in accordance with the requirements } \\
\text { in this Chapter: } \\
\text { From DOE G 435.1-1 Chapter III: Compliance with }\end{array}$ & See below. \\
\hline
\end{tabular}


TRA-670, Advanced Test Reactor, and TRA-1005, Advanced Test Reactor Storage Pad

Chapter III, Transuranic Waste Requirements Facility Compliance Information

these requirements is demonstrated if RCRA, statehazardous, and TSCA-regulated radioactive wastes are being managed in compliance with applicable requirements and agreements or in accordance with a consent order, and consistent with the Transuranic Waste Requirements of DOE M 435.1-1.

(1) Mixed Transuranic Waste. Transuranic waste determined to contain both a hazardous component subject to the Resource Conservation and Recovery Act (RCRA), as amended, and a radioactive component subject to the Atomic Energy Act of 1954, as amended, shall be managed in accordance with the requirements of RCRA and DOE O 435.1, Radioactive Waste Management, and this Manual.

(2) TSCA-Regulated Waste. Transuranic waste containing polychlorinated biphenyls, asbestos, or other facility. such regulated toxic components shall be managed in accordance with requirements derived from the Toxic Substances Control Act, as amended, DOE O 435.1, Radioactive Waste Management, and this Manual.

(3) Pre-1970 Transuranic Waste. Transuranic waste disposed of prior to implementation of the 1970 Atomic Energy Commission Immediate Action Directive regarding retrievable storage of transuranic waste is not subject to the requirements of DOE O 435.1, Radioactive Waste Management, and this Manual.

C. Complex-Wide Transuranic Waste Management Program. A complex-wide program and plan shall be developed as described under Responsibilities, 2.B and 2.D, in Chapter I of this Manual.

NA; mixed TRU waste is not managed at this facility.

From DOE G 435.1-1 Chapter III: Compliance with this requirement is demonstrated by the presence of a Complex-Wide Transuranic Waste Management Program which includes the appropriate interfaces, technical information, data inputs, and other elements described in Chapter I of this Manual.

D. Radioactive Waste Management Basis. Transuranic waste facilities, operations, and activities shall have a radioactive waste management basis consisting of physical and administrative controls to ensure the protection of workers, the public, and the environment. The following specific waste management controls shall be part of the radioactive waste management basis:

From DOE G 435.1-1 Chapter III: Compliance with this requirement is demonstrated if, the radioactive waste management basis is documented and signed by the Field Element manager or a designee (see DOE M 435.1-1, Section I.1.A, Delegation of Authority) for each transuranic waste management facility, operation,

Not a facility-specific requirement. DOE Manual 435.1-1

§I.2.B and §I.2.D apply to the Assistant Secretary for Environmental Management and the Deputy Assistant Secretary for Waste Management, respectively.

The RWMB provides the regulatory framework for management of radioactive waste at INL. It specifically identifies facility management and implementing documents for the generation, storage, treatment, and disposal of radiological waste.

SAR-153 establishes the facility as a Hazard Category 1 nuclear facility and states that TRA-1005 was considered in this safety basis. SAR-153 $\S \S 1.1 .2$ and 11.5.3 indicate that TRA-1005 is part of the ATR facility. 
or activity. Using a graded approach, it may be possible to include multiple activities under a single radioactive waste management basis, but it should be possible to objectively identify which activities are covered. Further, the radioactive waste management basis includes or references the controls that are established on a facility-specific basis to address the unique waste management requirements and circumstances for each facility, operation, and/or activity.

(1) Generators. The waste certification program.

NA; waste is not generated at this facility.

From DOE G 435.1-1 Chapter III: For a facility that generates transuranic waste, the radioactive waste management basis is to include the program for certifying that waste meets the waste acceptance requirements of the facility(ies) to which the waste will be sent.

(2) Treatment Facilities. certification program. The waste acceptance requirements and the waste [sic]

From DOE G 435.1-1 Chapter III: Facilities that store or treat transuranic waste are to have approved waste acceptance requirements (see DOE M 435.1-1, Section III.G) prior to the issuance of a radioactive waste management basis. The waste acceptance requirements will usually suffice as documentation of the radiological, physical, and chemical limitations on waste that can be safely received at the facility, provided they are developed correctly with consideration of the hazards of the waste to be managed, and are kept up to date. Controls on the radiological, physical and chemical limitations need to include considerations of the potential effects of radiolysis.

A facility that stores or treats waste is generally expected to have a waste certification program. Waste from these facilities will have to be certified as meeting the waste acceptance requirements of the facility to which it will be transferred and the facilities have the potential for generating radioactive waste (e.g., secondary processing streams from treatment, monitoring and sampling, radioactive release cleanup). Consequently, storage and treatment facilities should also have an approved waste certification program as part of their radioactive waste management basis.

As part of the radioactive waste management basis, site personnel should implement a system or process for tracking the waste inventory at a storage, treatment, or disposal facility.

(3) Storage Facilities. The waste acceptance requirements and the waste certification program.

NA; waste is not treated at this facility.

See G. and J. below for waste acceptance and waste certification program requirements. 
TRA-670, Advanced Test Reactor, and TRA-1005, Advanced Test Reactor Storage Pad

Chapter III, Transuranic Waste Requirements

From DOE G 435.1-1 Chapter III: Facilities that store or treat transuranic waste are to have approved waste acceptance requirements (see DOE M 435.1-1, Section

III.G) prior to the issuance of a radioactive waste management basis. The waste acceptance requirements will usually suffice as documentation of the radiological, physical, and chemical limitations on waste that can be safely received at the facility, provided they are developed correctly with consideration of the hazards of the waste to be managed, and are kept up to date. Controls on the radiological, physical and chemical limitations need to include considerations of the potential effects of radiolysis.

A facility that stores or treats waste is generally expected to have a waste certification program. Waste from these facilities will have to be certified as meeting the waste acceptance requirements of the facility to which it will be transferred and the facilities have the potential for generating radioactive waste (e.g., secondary processing streams from treatment, monitoring and sampling, radioactive release cleanup). Consequently, storage and treatment facilities should also have an approved waste certification program as part of their radioactive waste management basis.

As part of the radioactive waste management basis, site personnel should implement a system or process for tracking the waste inventory at a storage, treatment, or disposal facility.

(4) Disposal Facilities. The performance assessment, disposal authorization statement, waste acceptance requirements, and monitoring plan.

E. Contingency Actions. The following requirements are in addition to those in Chapter I of this Manual.

From DOE G 435.1-1 Chapter III: Compliance with these requirements is demonstrated by having adequate spare capacity and transfer equipment exists for emergency transfers of all liquid transuranic waste. In addition, the capability to perform emergency transfers is demonstrated by having waste transfer routings identified, operational procedures to direct transfers, staff trained to the procedures, and records showing that the spare capacity and transfer capability are kept in operating condition.

(1) Contingency Storage. For off-normal or emergency situations involving liquid transuranic waste storage or treatment, spare capacity with adequate capabilities shall be maintained to receive the largest volume of liquid contained in any one storage tank or treatment facility. Tanks or other facilities that are designated

\section{Facility Compliance Information}

Waste stored at this facility is tracked in IWTS. However, the waste is designated as ATR rather than TRA-1005.
NA; this facility is not a disposal facility.

Not a facility-specific requirement. DOE Manual 435.1-1 $\S$ I.1.E(5) addresses the sitewide emergency management system. The INL plan is provided in PLN-114.

$\mathrm{NA}$; this facility does not store or treat liquid waste in tanks. 
TRA-670, Advanced Test Reactor, and TRA-1005, Advanced Test Reactor Storage Pad

Chapter III, Transuranic Waste Requirements

transuranic waste contingency storage shall be maintained in an operational condition when waste is present and shall meet the requirements of DOE O 435.1, Radioactive Waste Management, and this Manual.

(2) Transfer Equipment. Pipelines and auxiliary facilities necessary for the transfer of liquid waste to contingency storage shall be maintained in an operational condition when waste is present and shall meet the requirements of DOE O 435.1, Radioactive Waste Management, and this Manual.

F. Corrective Actions. I of this Manual. The following requirements are in addition to those in Chapter [sic]
NA; this facility does not store or treat liquid waste in tanks.
Facility Compliance Information

The INL-wide procedure addressing problem identification as required by DOE Manual 435.1-1 §I.2.G.(1) is LWP-13840, which implements the laboratory's corrective action system.

The INL-wide procedure addressing shutdown or curtailment of activities as required by DOE Manual 435.11 §I.2.G.(2) is LWP-14002.

1) Order Compliance. Corrective actions shall be implemented whenever necessary to ensure the requirements of DOE O 435.1, Radioactive Waste Management, and this Manual are met.

From DOE G 435.1-1 Chapter III: If a facility or activity can be allowed to operate while a noncompliant or hazardous condition exists, the allowance and any associated limitations must be defined as part of the facility's or activity's radioactive waste management basis, identified as a configuration controlled item in a configuration management plan or included in a revision or modification to an operating procedure or similar controlled documentation.

Compliance with this requirement is demonstrated if a corrective action system exists which addresses noncompliant or hazardous situations associated with transuranic waste management and in a systematic fashion, and allows identification of problems by all personnel.

(2) Operations Curtailment. Operations shall be curtailed or facilities shut down for failure to establish, maintain, or operate consistent with an approved radioactive waste management basis.

From DOE G 435.1-1 Chapter III: Compliance with this requirement is demonstrated by documented evidence of systematic, routine reviews to determine whether waste management activities and facilities under are operating in accordance with an approved radioactive waste management basis. In addition, the documentation should show that limitations (which may include

See F. above.

The approved RWMB establishes the current compliance status at each radioactive waste management facility. Facility assessments are scheduled to ensure waste management activities are conducted in accordance with the approved RWMB. 
TRA-670, Advanced Test Reactor, and TRA-1005, Advanced Test Reactor Storage Pad

Chapter III, Transuranic Waste Requirements Facility Compliance Information

shutdown) have been placed on activities and operations that do not have or are operating outside the conditions of an approved radio

G. Waste Acceptance. The following requirements are in addition to those in Chapter I of this Manual.

Not a facility-specific requirement. DOE Manual 435.1-1 §I.2.F(6) applies to field element managers.

1) Technical and Administrative. Waste acceptance requirements for all transuranic waste storage, treatment, or disposal facilities, operations, and SAR-153 establishes the facility as a Hazard Category 1 nuclear facility and states that TRA-1005 was considered in this safety basis. SAR-153 $\S \S 1.1 .2$ and 11.5.3 indicate that activities shall specify, at a minimum, the following:

From DOE G 435.1-1 Chapter III: Compliance with these requirements is demonstrated if waste acceptance requirements are documented, contain clear and precise criteria specifying the radionuclide limits in the form of contents or concentrations that can be accepted, the limitations and prohibitions on waste forms and packages that can be received, and the limits, prohibitions, or instructions concerning any other technical information so that the waste is compatible with the safety basis of the facility, and which will result in acceptable waste at subsequent steps in managing the transuranic waste. Waste acceptance requirements are to also contain a clear description of the process and bases for obtaining an exception or deviation to the acceptance criteria for transuranic waste to be received at the facility.

(a) Allowable activities and/or concentrations of specific radionuclides;

TRA-1005 is part of the ATR facility.

The TRU waste at this facility is legacy remote-handled TRU waste that is being proposed for transfer to the DOE-EM contractor for management and disposition. Additional TRU waste is not planned to be received at this facility.

(b) Acceptable waste form and/or container requirements that ensure the chemical and physical stability of waste under conditions that might be encountered during transportation, storage, treatment, or disposal;

(c) Restrictions or prohibitions on waste, materials, or containers that may adversely affect waste handlers or compromise facility or waste container performance;

(d) Requirement to identify transuranic waste as defense See (1) above. or non-defense, and limitations on acceptance; and

(e) The basis, procedures, and levels of authority $\quad$ NA; this facility is a Hazard Category 1 nuclear facility. required for granting exceptions to the waste acceptance Therefore, radioactive material inventory limits are not requirements, which shall be contained in each facility's tracked for this facility. waste acceptance documentation. Each exception request shall be documented, including its disposition as approved or not approved.

(2) Evaluation and Acceptance. The receiving facility shall evaluate waste for acceptance, including confirmation that technical and administrative requirements have been met. A process for the

See (1) above.

See (1) above.

See (1) above.

See (1) above.


Chapter III, Transuranic Waste Requirements disposition of non-conforming wastes shall be established.

From DOE G 435.1-1 Chapter III: Compliance with these requirements is demonstrated if there is a procedure or process for evaluating and accepting incoming waste which ensures the acceptance criteria of the facility receiving the waste are met by one or a combination of: (1) testing, sampling, and analysis of representative samples of incoming waste upon receipt; (2) testing, sampling, and analysis of samples of waste taken at the generator facility; (3) evaluation of testing, sampling, and analysis of data provided by the generator; or (4) audits, reviews, or surveillances of generator waste certification programs and characterization activities. Additionally, acceptable waste acceptance requirements for a storage, treatment, or disposal facility will have documented procedures and actions to be taken if a waste that does not conform to the waste acceptance criteria is received at the facility.

H. Waste Generation Planning. The following requirements are in addition to those in Chapter I of this Manual.

1) Life-Cycle Planning. Prior to waste generation, planning shall be performed to address the entire life cycle for all transuranic waste streams.

From DOE G 435.1-1 Chapter III: Compliance with this planning requirement is demonstrated by the individual sites establishing a process for evaluating the life-cycle of [transuranic] waste prior to its generation, including the identification of [transuranic] wastes with no path to disposal and appropriate records justifying the newly generated [transuranic] waste stream(s), and site personnel possessing planning information showing the location(s) where [transuranic] waste will be stored, treated, and/or disposed along with a confirmation that the personnel managing the facilities agree that the [transuranic] waste may be managed at those facilities.

(2) Waste with No Identified Path to Disposal. Transuranic waste streams with no identified path to disposal shall be generated only in accordance with approved conditions which, at a minimum, shall address:

From DOE G 435.1-1 Chapter III: Compliance with requirement is demonstrated by the waste generation organization having documentation concerning the decision to generate a transuranic waste stream that does not have an identified path to disposal. This documentation needs to include the cognizant Field
Not a facility-specific requirement. DOE Manual 435.1-1

$\S$ I.2.F(7) applies to field element managers. NA; TRU waste is not generated at this facility.

NA; TRU waste is not generated at this facility. Facility Compliance Information 
TRA-670, Advanced Test Reactor, and TRA-1005, Advanced Test Reactor Storage Pad

Chapter III, Transuranic Waste Requirements Facility Compliance Information

Element Manager or designee approval to generate the waste, an explanation of the need for the process that generates the transuranic waste, a discussion of the reason it cannot be disposed of, the proposed management plan for the waste, and an up-to-date schedule of activities being pursued to resolve constraints to the disposal of the subject waste. Consistent with the use of a graded approach for applying DOE M 435.1-1 requirements, the schedule and plans for disposing of nondefense waste can defer to the complex-wide resolution of the issue.

(a) Programmatic need to generate the waste; See (2) above.

(b) Characteristics and issues preventing the disposal of See (2) above. the waste;

(c) Safe storage of the waste until disposal can be achieved; and

(d) Activities and plans for achieving final disposal of the waste.

I. Waste Characterization. Transuranic waste shall be characterized using direct or indirect methods, and the characterization documented in sufficient detail to ensure safe management and compliance with the waste acceptance requirements of the facility receiving the waste.

From DOE G 435.1-1 Chapter III: Compliance with this requirement is demonstrated by a program for documenting and the existence of records that document the process for acquiring and verifying the validity of transuranic waste characterization data acquired through the use of direct or indirect methods.

(1) Data Quality Objectives. The data quality objectives process, or a comparable process, shall be used for identifying characterization parameters and acceptable uncertainty in characterization data.

See (2) above.

See (2) above.

The waste acceptance criteria will be established by the DOE-EM contractor to which this waste is proposed to be transferred. Acceptable knowledge and characterization information will be provided to demonstrate compliance with these criteria.

From DOE G 435.1-1 Chapter III: Compliance with this requirement is demonstrated by the documented use of a data quality objectives or a comparable process for determining the type, quantity, and quality of characterization data needed to safely manage transuranic waste.

(2) Minimum Waste Characterization. Characterization data shall, at a minimum, include the following information relevant to the management of the waste:

Radioactive waste management facilities characterize waste in accordance with the requirements of the receiving storage, treatment, or disposal facility. The documented use of a data quality objectives process, or comparable process, was not identified for this facility.

From DOE G 435.1-1 Chapter III: Compliance with this requirement is demonstrated by the existence of a program or procedures for determining and records that document characterization of transuranic waste

MCP-17000 $\$ 4$ specifies the requirements for preparing an IWTS profile that captures waste characterization information. 
TRA-670, Advanced Test Reactor, and TRA-1005, Advanced Test Reactor Storage Pad

\begin{tabular}{l} 
Chapter III, Transuranic Waste Requirements \\
\hline $\begin{array}{l}\text { consistent with the minimum characterization data } \\
\text { requirements. }\end{array}$ \\
(a) Physical and chemical characteristics; \\
(b) Volume, including the waste and any stabilization or \\
absorbent media; \\
(c) Weight of the container and contents; \\
(d) Identities, activities, and concentrations of major \\
radionuclides; \\
(e) Characterization date; \\
(f) Generating source; \\
(g) Packaging date; and \\
\hline
\end{tabular}

(h) Any other information which may be needed to prepare and maintain the disposal facility performance assessment or demonstrate compliance with applicable performance objectives.

J. Waste Certification. A waste certification program shall be developed, documented, and implemented to ensure that the waste acceptance requirements of facilities receiving transuranic waste for storage, treatment, or disposal are met.

From DOE G 435.1-1 Chapter III: Compliance with the development and documentation portion of the certification requirement is demonstrated by a waste certification plan that identifies the organizations involved, assigns responsibilities for implementing the program, and describes or references the quality assurance, training, procurement controls, records management, and procedures to be used by the program. Acceptable performance for implementing the program is demonstrated when the appropriate personnel are trained, and have and follow the procedures that govern their part of the waste certification process. Acceptable performance also requires that the waste certification plan and procedures are current and controlled in accordance with a document control program, and records related to certification (e.g., certification statements, training records, procurement records, characterization records, container records) are generated and managed in accordance with the established site program.

1) Certification Program. The waste certification program shall designate the officials who have the authority to certify and release waste for shipment; and specify what documentation is required for waste generation, characterization, shipment, and certification. The program shall provide requirements for auditability,
See (2) above.

See (2) above.

See (2) above.

See (2) above.

See (2) above.

See (2) above.

See (2) above.

See (2) above.

NA; no certification program for this waste. The TRU waste at this facility is legacy remote-handled TRU waste that is being proposed for transfer to the DOE-EM contractor for management and disposition. Acceptable knowledge and characterization information will be provided to demonstrate compliance with the DOE-EM waste acceptance criteria for the receiving organization to enable transfer of ownership.

See J. above. 
From DOE G 435.1-1 Chapter III: Compliance with this requirement is demonstrated by a program or procedure for record keeping and records showing that each container of waste is certified as having met the waste acceptance criteria of the facility to which it was transferred and the certification statement is supported by additional records regarding the waste source, characterization, and container.

(2) Certification before Transfer. Transuranic waste shall be certified as meeting waste acceptance requirements before it is transferred to the facility receiving the waste.

From DOE G 435.1-1 Chapter III: Compliance with this requirement is demonstrated by the presence of a certification program which includes procedures requiring a signed certification statement prior to the release of waste for transfer, and by dated records showing that waste was certified before being transferred.

(3) Maintaining Certification. Transuranic waste that has been certified as meeting the waste acceptance requirements for transfer to a storage, treatment, or disposal facility shall be managed in a manner that maintains its certification status.

From DOE G 435.1-1 Chapter III: Compliance with this requirement is demonstrated by the existence of a program or procedure reflecting this requirement and site personnel able to show that the storage of containers of waste is in a facility or manner where the containers are not damaged by normal weather events, and cannot be accessed by unauthorized personnel. Further, each container can be traced to its certification and the information supporting that certification.

K. Waste Transfer. A documented process shall be established and implemented for transferring responsibility for management of transuranic waste and for ensuring availability of relevant data. The following requirements are in addition to those in Chapter I of this Manual.

From DOE G 435.1-1 Chapter III: Compliance with this requirement is demonstrated if facilities have procedures for the receipt of waste and the transfer of waste, as appropriate, which address the acquisition of waste and container data and the transfer of ownership, respectively. Further evidence of acceptable performance is facility records showing that data on the waste containers are available and accurate, and that
See J. above. Facility Compliance Information
See J. above.

Waste transfer for TRU waste at this facility is limited to the one-time transfer of the legacy remote-handled TRU waste managed at this facility. A waste-specific agreement will be developed to transfer management responsibility to the DOE-EM contractor for this waste. 
TRA-670, Advanced Test Reactor, and TRA-1005, Advanced Test Reactor Storage Pad

Chapter III, Transuranic Waste Requirements Facility Compliance Information

documented transfer of responsibility occurs.

(1) Authorization. Transuranic waste shall not be

See K. above. transferred to a storage, treatment, or disposal facility until personnel responsible for the facility receiving the waste authorize the transfer.

From DOE G 435.1-1 Chapter III: Compliance with this requirement is demonstrated by sites having procedures that require a confirmation of authorization before releasing waste for transfer, and records showing that transfers are made in accordance with written authorizations.

(2) Data. Waste characterization data, container information, and generation, storage, treatment, and transportation information for transuranic waste shall be transferred with or be traceable to the waste.

From DOE G 435.1-1 Chapter III: Compliance with this requirement is demonstrated if there are procedures requiring that characterization and container data be provided and maintained for each waste transfer and documented records of transfers show that the information is being provided.

L. Packaging and Transportation. The following requirements are in addition to those in Chapter I of this Manual.

\section{(1) Packaging.}

From DOE G 435.1-1 Chapter III: Compliance with the packaging requirement is demonstrated by procedures which document proper packaging protocols, including documented evidence that, where feasible, non-defense transuranic waste has been packaged separately from defense transuranic waste and by never having to repackage transuranic waste that is packaged after issuance of DOE O 435.1 in order to maintain containment. However, the above protocol may not be satisfied by containers that were placed in storage prior to issuance of the DOE O 435.1. For those containers, the goal is to only have to repackage the waste one time after it is retrieved and characterized. Further, acceptable performance is demonstrated by containers of waste having marking and labeling that allows correlation with waste characterization data and container information. Successful performance of this requirement is also demonstrated by a record of container performance in which failure has not routinely occurred.

(a) Transuranic waste shall be packaged in a manner that provides containment and protection for the duration of the anticipated storage period and until disposal is achieved or until the waste is removed from the container.
See K. above.

See (1) and (2) below.

The TRU waste at this facility is legacy remote-handled TRU waste that is being proposed for transfer to the DOE-EM contractor for management and disposition. Acceptable knowledge and characterization information will be provided to demonstrate compliance with the DOE-EM waste acceptance criteria for the receiving organization to enable transfer of ownership. These criteria would include requirements for packaging. The acceptable knowledge documentation is expected to indicate the waste is defense waste. 
TRA-670, Advanced Test Reactor, and TRA-1005, Advanced Test Reactor Storage Pad

Chapter III, Transuranic Waste Requirements Facility Compliance Information

(b) Vents or other mechanisms to prevent pressurization See (1) above. of containers or generation of flammable or explosive concentrations of gases shall be installed on containers of newly-generated waste at the time the waste is packaged. Containers of currently stored waste shall meet this requirement as soon as practical unless analyses demonstrate that the waste can otherwise be managed safely.

(c) When transuranic waste is packaged, defense waste See (1) above. shall be packaged separately from non-defense waste, if feasible.

(d) Containers of transuranic waste shall be marked such that their contents can be identified.

(2) Transportation. To the extent practical, the volume of waste and number of transuranic waste shipments shall be minimized.

From DOE G 435.1-1 Chapter III: Compliance with this requirement can be demonstrated by a combination of site procedures directing the efficient use of waste container capacity and documentation showing that transuranic waste shipments are systematically planned and make optimal use of the shipment system (e.g., TRUPACT II) to the extent practical.

M. Site Evaluation and Facility Design. The following requirements are in addition to those in Chapter I of this Manual.

(1) Site Evaluation. Proposed locations for transuranic See M. above. waste facilities shall be evaluated to identify relevant features that should be avoided or must be considered in facility design and analyses.

(a) Each site proposed for a new transuranic waste facility or expansion of an existing transuranic waste facility shall be evaluated considering environmental characteristics, geotechnical characteristics, and human activities.

(b) Proposed sites with environmental characteristics, geotechnical characteristics, and human activities for which adequate protection cannot be provided through facility design shall be deemed unsuitable for the location of the facility.

(2) Facility Design. The following facility requirements See M. above. and general design criteria, at a minimum, apply:

(a) Confinement. Transuranic waste systems and components shall be designed to maintain waste confinement.

(b) Ventilation.

NA; this requirement addresses new radioactive waste management facilities or modifications to existing facilities.

NA; waste is not shipped to an offsite facility for final disposition from this facility.

See M. above.

See M. above.

See above.

See M. above. 
TRA-670, Advanced Test Reactor, and TRA-1005, Advanced Test Reactor Storage Pad

Chapter III, Transuranic Waste Requirements

1 Design of transuranic waste treatment and storage facilities shall include ventilation, if applicable, through an appropriate filtration system to maintain the release of radioactive material in airborne effluents within the requirements and guidelines specified in applicable requirements.

2 When conditions exist for generating gases in flammable or explosive concentrations in treatment or storage facilities, ventilation or other measures shall be provided to keep the gases in a non-flammable and nonexplosive condition. Where concentrations of explosive or flammable gases are expected to approach the lower flammability limit, measures shall be taken to prevent deflagration or detonation.

(c) Consideration of Decontamination and Decommissioning. Areas in new and modifications to existing transuranic waste management facilities that are subject to contamination with radioactive or other hazardous materials shall be designed to facilitate decontamination. For such facilities a proposed decommissioning method or a conversion method leading to reuse shall be described.

(d) Instrumentation and Control Systems. Engineering controls shall be incorporated in the design and engineering of transuranic waste treatment and storage facilities to provide volume inventory data and to prevent spills, leaks, and overflows from tanks or confinement systems.

(e) Monitoring. Monitoring and/or leak detection capabilities shall be incorporated in the design and engineering of transuranic waste storage, treatment, and disposal facilities to provide rapid identification of failed confinement and/or other abnormal conditions.

N. Storage. The following requirements are in addition to those in Chapter I of this Manual.

(1) Storage Prohibitions. Transuranic waste in storage shall not be readily capable of detonation, explosive decomposition, reaction at anticipated pressures and temperatures, or explosive reaction with water. Prior to storage, pyrophoric materials shall be treated, prepared, and packaged to be nonflammable.

From DOE G 435.1-1 Chapter III: Compliance with this requirement is demonstrated by having waste acceptance requirements which prohibit waste that is ignitable or explosive from being accepted for storage unless it has been treated.

2) Storage Integrity. Transuranic waste shall be stored in a location and manner that protects the integrity of
Facility Compliance Information

See M. above.

See M. above.

See M. above.

See M. above.

See M. above.

See below.

A facility-specific procedure addressing this requirement was not identified.
LWP-15011 $\$ 5$ provides general radioactive storage area requirements and $\S 5.1 .7$ addresses outdoor storage of 
TRA-670, Advanced Test Reactor, and TRA-1005, Advanced Test Reactor Storage Pad

Chapter III, Transuranic Waste Requirements waste for the expected time of storage and minimizes worker exposure.

From DOE G 435.1-1 Chapter III: Compliance with this requirement is demonstrated if sites have storage capabilities for transuranic waste that provide protection of waste containers so that their integrity will not be damaged through physical or chemical (corrosion) processes and that keep personnel from spending extended periods of time in the areas where transuranic waste is stored.

(3) Container Inspection. A process shall be developed and implemented for inspecting and maintaining containers of transuranic waste to ensure container integrity is not compromised.

radioactive material.

From DOE G 435.1-1 Chapter III: Compliance with this requirement is demonstrated by a documented process for waste container inspection and maintenance at every facility managing transuranic waste, and documentation for all waste container inspections and maintenance actions performed.

(4) Retrievable Earthen-Covered Storage. Plans for the removal of transuranic waste from retrievable earthencovered storage facilities shall be established and maintained. Prior to commencing waste retrieval activities, each waste storage site shall be evaluated to determine relevant information on types, quantities, and location of radioactive and hazardous chemicals as necessary to protect workers during the retrieval process.

O. Treatment. Transuranic waste shall be treated as necessary to meet the waste acceptance requirements of the facility receiving the waste for storage or disposal.

From DOE G 435.1-1 Chapter III: Compliance with this requirement is demonstrated by the custodian of transuranic waste maintaining documentation which identifies the plans for treating waste, and maintaining the records that show waste was treated, if necessary, to meet the waste acceptance requirements of the storage or disposal facility to which it was transferred.

P. Disposal. Transuranic waste shall be disposed in accordance with the requirements of 40 CFR Part 191, Environmental Radiation Protection Standards for Management and Disposal of Spent Nuclear Fuel, HighLevel and Transuranic Radioactive Wastes.

Q. Monitoring. The following requirements are in addition to those in Chapter I of this Manual.

(1) All Waste Facilities. Parameters that shall be sampled or monitored, at a minimum, include:

NA; this facility is not an earthen-covered storage facility.

LI-435 requires quarterly inspections of radioactive waste containers if waste is stored outdoors or has been in storage for greater than 1 year.

NA; TRU waste is not treated at this facility.

NA; TRU waste is not disposed of at this facility.

See (1), (2), and (3) below.

Monitoring requirements at INL radioactive waste management facilities are tailored for the specific facility to 
TRA-670, Advanced Test Reactor, and TRA-1005, Advanced Test Reactor Storage Pad

Chapter III, Transuranic Waste Requirements

Facility Compliance Information

temperature, pressure (for closed systems), radioactivity enable timely indication of developing problems. Existing in ventilation exhaust and liquid effluent streams, and flammable or explosive mixtures of gases. Facility monitoring programs shall include verification that passive and active control systems have not failed.

From DOE G 435.1-1 Chapter III: If a minimum parameter specified in the requirement is deemed to be not applicable in any way to the active operation of that facility, then that justification should be included in the radioactive waste management basis and when approved, constitutes an exemption to the Manual.

Verification activities are part of the radioactive waste management basis and are to be documented appropriately.

Compliance with this requirement is demonstrated if monitoring or sampling for the stated parameters is performed for all facilities with an accuracy, precision, and frequency consistent with timely identification of developing problems and a justification exists in the approved radioactive waste management basis for those specified parameters which are not monitored or sampled.

(2) Stored Wastes. All transuranic wastes in storage shall be monitored, as prescribed by the appropriate facility safety analysis, to ensure the wastes are maintained in safe condition.

From DOE G 435.1-1 Chapter III: Compliance with this requirement is demonstrated if the monitoring requirements in the facility procedures include, at a minimum, monitoring the systems and parameters as indicated by the safety analysis.

(3) Liquid Waste Storage Facilities. For facilities storing NA; liquid TRU waste is not stored at this facility. liquid transuranic waste, the following shall also be monitored: liquid level and/or waste volume, and significant waste chemistry parameters.

From DOE G 435.1-1 Chapter III: Compliance with this requirement is demonstrated by developing operational procedures for monitoring liquid transuranic waste storage tank liquid level, waste volume, and tank chemistry so that waste volume or chemistry changes are detected in a time frame that will allow implementation of corrective measures to limit public and worker doses and to mitigate unplanned releases of stored liquid waste. 
Table 7. TRA-670, Advanced Test Reactor, DOE Manual 435.1-1 low-level waste requirements and facility compliance information.

\begin{tabular}{|c|c|}
\hline \multicolumn{2}{|c|}{$\begin{array}{l}\text { Facility Name: TRA-670, ATR Reactor Facility } \\
\text { (includes TRA-605, Warm Waste Treatment Facility, and TRA-1005, Advanced Test Reactor Storage Pad) }\end{array}$} \\
\hline Chapter IV, LLW Requirements & Facility Compliance Information \\
\hline $\begin{array}{l}\text { A. Definition of Low-Level Waste. Low-level } \\
\text { radioactive waste is radioactive waste that is not high- } \\
\text { level radioactive waste, spent nuclear fuel, transuranic } \\
\text { waste, byproduct material (as defined in section } 11 \mathrm{e} .(2) \\
\text { of the Atomic Energy Act of } 1954 \text {, as amended), or } \\
\text { naturally occurring radioactive material. } \\
\text { (From DOE G } 435.1-1 \text { Chapter IV: Low-level } \\
\text { radioactive waste is defined by what it is not. The } \\
\text { guidance on definitions in Chapters II and III should be } \\
\text { consulted first for making a determination on how to } \\
\text { properly manage a suspect waste stream.) }\end{array}$ & $\begin{array}{l}\text { This requirement provides the criteria for determining } \\
\text { which DOE radioactive waste is to be managed as LLW } \\
\text { in accordance with DOE Manual } 435.1-1 \text {, Chapter IV. } \\
\text { Radioactive waste managed at this facility under the } \\
\text { requirements of this chapter is not managed under the } \\
\text { requirements of DOE Manual } 435.1-1 \text {, Chapter II or } \\
\text { Chapter III. }\end{array}$ \\
\hline $\begin{array}{l}\text { B. Management of Specific Wastes. The following } \\
\text { provide for management of specific wastes as low-level } \\
\text { waste in accordance with the requirements in this } \\
\text { Chapter: }\end{array}$ & See (1), (2), (3), and (4) below. \\
\hline $\begin{array}{l}\text { (1) Mixed Low-Level Waste. Low-level waste } \\
\text { determined to contain both source, special nuclear, or } \\
\text { byproduct material subject to the Atomic Energy Act of } \\
1954 \text {, as amended, and a hazardous component subject to } \\
\text { the Resource Conservation and Recovery Act (RCRA), } \\
\text { as amended, shall be managed in accordance with the } \\
\text { requirements of RCRA and DOE O 435.1, Radioactive } \\
\text { Waste Management, and this Manual. }\end{array}$ & $\begin{array}{l}\text { This facility manages mixed LLW in SAAs. } \\
\text { Management of SAAs is addressed in MCP-17410, and } \\
\text { overall management of mixed waste is addressed in } \\
\text { MCP-17000. }\end{array}$ \\
\hline $\begin{array}{l}\text { (2) TSCA-Regulated Waste. Low-level waste containing } \\
\text { polychlorinated biphenyls, asbestos, or other such } \\
\text { regulated toxic components shall be managed in } \\
\text { accordance with requirements derived from the Toxic } \\
\text { Substances Control Act, as amended, DOE O } 435.1 \text {, } \\
\text { Radioactive Waste Management, and this Manual. }\end{array}$ & $\begin{array}{l}\text { NA; this facility does not manage TSCA-regulated } \\
\text { waste. }\end{array}$ \\
\hline $\begin{array}{l}\text { (3) Accelerator-Produced Waste. Radioactive waste } \\
\text { produced as a result of operations of DOE accelerators is } \\
\text { low-level waste and shall be managed in accordance with } \\
\text { DOE O 435.1, Radioactive Waste Management, and this } \\
\text { Manual, and all applicable Federal or State requirements. }\end{array}$ & $\begin{array}{l}\text { NA; this facility does not manage accelerator-produced } \\
\text { waste. }\end{array}$ \\
\hline $\begin{array}{l}\text { (4) } 11 \text { e.(2) and Naturally Occurring Radioactive } \\
\text { Material. Small quantities of } 11 \text { e.( } 2 \text { ) byproduct material } \\
\text { and naturally occurring radioactive material may be } \\
\text { managed as low-level waste provided they can be } \\
\text { managed to meet the requirements for low-level waste } \\
\text { disposal in Section IV.P of this Manual. }\end{array}$ & $\begin{array}{l}\mathrm{NA} \text {; this facility does not manage naturally occurring } \\
\text { radioactive material. }\end{array}$ \\
\hline $\begin{array}{l}\text { C. Complex-Wide Low-Level Waste Management } \\
\text { Program. A complex-wide program and plan shall be } \\
\text { developed as described under Responsibilities, 2.B and } \\
\text { 2.D, in Chapter I of this Manual. }\end{array}$ & $\begin{array}{l}\text { DOE Manual 435.1-1 §I.2.B and } \S \text { I.2.D apply to the } \\
\text { Assistant Secretary for Environmental Management and } \\
\text { the Deputy Assistant Secretary for Waste Management, } \\
\text { respectively. }\end{array}$ \\
\hline
\end{tabular}


Table 7. (continued).

\begin{tabular}{|c|c|}
\hline \multicolumn{2}{|c|}{$\begin{array}{c}\text { Facility Name: TRA-670, ATR Reactor Facility } \\
\text { (includes TRA-605, Warm Waste Treatment Facility, and TRA-1005, Advanced Test Reactor Storage Pad) }\end{array}$} \\
\hline Chapter IV, LLW Requirements & Facility Compliance Information \\
\hline $\begin{array}{l}\text { D. Radioactive Waste Management Basis. Low-level } \\
\text { waste facilities, operations, and activities shall have a } \\
\text { radioactive waste management basis consisting of } \\
\text { physical and administrative controls to ensure the } \\
\text { protection of workers, the public, and the environment. } \\
\text { The following specific waste management controls shall } \\
\text { be part of the radioactive waste management basis: }\end{array}$ & $\begin{array}{l}\text { The RWMB provides the regulatory framework for } \\
\text { management of radioactive waste at INL. It specifically } \\
\text { identifies facility management and implementing } \\
\text { documents for the generation, storage, treatment, and } \\
\text { disposal of radiological waste. }\end{array}$ \\
\hline $\begin{array}{l}\text { (1) Generators. The waste certification program. } \\
\text { From DOE G } 435.1-1 \text { Chapter IV: For a facility that } \\
\text { generates low-level waste, the radioactive waste } \\
\text { management basis is to include the program for } \\
\text { certifying that waste meets the waste acceptance } \\
\text { requirements of the facility(ies) to which the waste will } \\
\text { be sent. }\end{array}$ & $\begin{array}{l}\text { See J. below for waste certification program } \\
\text { requirements. } \\
\text { SAR-153 establishes this facility as a Hazard Category } 1 \\
\text { nuclear facility and states that TRA-1005 and TRA-605 } \\
\text { were considered in this safety basis. SAR-153 } \$ \$ 1.1 .2 \\
\text { and } 11.5 .3 \text { indicate that TRA-1005 and TRA-605 are } \\
\text { part of the ATR facility. }\end{array}$ \\
\hline $\begin{array}{l}\text { (2) Treatment Facilities. certification program. The waste } \\
\text { acceptance requirements and the waste [sic] } \\
\text { From DOE G 435.1-1 Chapter IV: Facilities that store or } \\
\text { treat low-level waste are to have approved waste } \\
\text { acceptance requirements (see DOE M 435.1-1, Section } \\
\text { IV.G) prior to the issuance of a radioactive waste } \\
\text { management basis. } \\
\text { A facility that stores or treats waste also is generally } \\
\text { expected to have a waste certification program. Waste } \\
\text { from these facilities will have to be certified as meeting } \\
\text { the waste acceptance requirements of the facility to } \\
\text { which it will be transferred, and the facilities have the } \\
\text { potential for generating radioactive waste (e.g., } \\
\text { secondary processing streams from treatment, monitoring } \\
\text { and sampling, radioactive release cleanup). } \\
\text { Consequently, storage and treatment facilities should } \\
\text { also have an approved waste certification program as part } \\
\text { of their radioactive waste management basis. } \\
\text { As part of the radioactive waste management basis, site } \\
\text { personnel needs to implement a system or process for } \\
\text { tracking the waste inventory at a storage, treatment, or } \\
\text { disposal facility. }\end{array}$ & $\begin{array}{l}\text { NA; this facility is not a radioactive waste treatment } \\
\text { facility. } \\
\end{array}$ \\
\hline $\begin{array}{l}\text { (3) Storage Facilities. The waste acceptance } \\
\text { requirements and the waste certification program. }\end{array}$ & $\begin{array}{l}\text { For TRA- } 670 \text {, see G. and J. below for waste acceptance } \\
\text { and waste certification program requirements. }\end{array}$ \\
\hline $\begin{array}{l}\text { From DOE G } 435.1-1 \text { Chapter IV: Facilities that store or } \\
\text { treat low-level waste are to have approved waste } \\
\text { acceptance requirements (see DOE M } 435.1-1 \text {, Section } \\
\text { IV.G) prior to the issuance of a radioactive waste } \\
\text { management basis. }\end{array}$ & $\begin{array}{l}\text { SAR-153 establishes this facility as a Hazard Category } 1 \\
\text { nuclear facility and states that TRA-1005 and TRA-605 } \\
\text { were considered in this safety basis. SAR-153 } \$ \S 1.1 .2 \\
\text { and } 11.5 .3 \text { indicate that TRA-1005 and TRA-605 are } \\
\text { part of the ATR facility. }\end{array}$ \\
\hline $\begin{array}{l}\text { A facility that stores or treats waste also is generally } \\
\text { expected to have a waste certification program. Waste }\end{array}$ & $\begin{array}{l}\text { SD-24.1.3 identifies administrative controls, a method of } \\
\text { compliance, and the responsible organization so that the }\end{array}$ \\
\hline
\end{tabular}


Table 7. (continued).

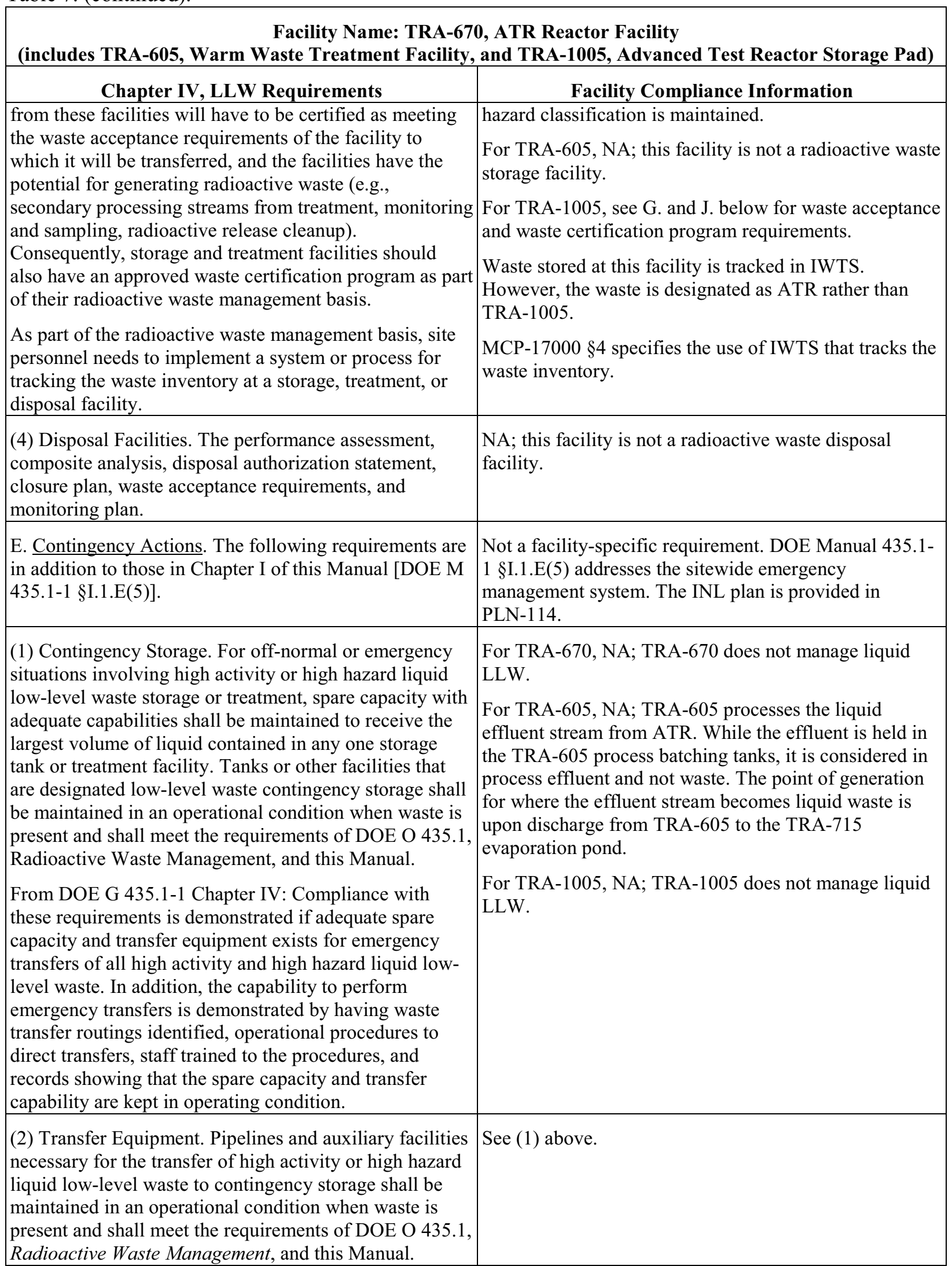


Table 7. (continued).

\begin{tabular}{|c|c|}
\hline \multicolumn{2}{|c|}{$\begin{array}{c}\text { Facility Name: TRA-670, ATR Reactor Facility } \\
\text { (includes TRA-605, Warm Waste Treatment Facility, and TRA-1005, Advanced Test Reactor Storage Pad) }\end{array}$} \\
\hline Chapter IV, LLW Requirements & Facility Compliance Information \\
\hline $\begin{array}{l}\text { From DOE G } 435.1-1 \text { Chapter IV: Compliance with } \\
\text { these requirements is demonstrated if adequate spare } \\
\text { capacity and transfer equipment exists for emergency } \\
\text { transfers of all high activity and high hazard liquid low- } \\
\text { level waste. In addition, the capability to perform } \\
\text { emergency transfers is demonstrated by having waste } \\
\text { transfer routings identified, operational procedures to } \\
\text { direct transfers, staff trained to the procedures, and } \\
\text { records showing that the spare capacity and transfer } \\
\text { capability are kept in operating condition. }\end{array}$ & \\
\hline $\begin{array}{l}\text { F. Corrective Actions. I of this Manual. The following } \\
\text { requirements are in addition to those in Chapter [sic] } \\
\text { From DOE G } 435.1-1 \text { Chapter IV: Compliance with } \\
\text { DOE M 435.1-1 §I.2.G.(1) is demonstrated by records } \\
\text { showing what corrective actions were taken to remedy } \\
\text { situations in the radioactive waste management system. } \\
\text { Compliance with DOE M } 435.1-1 \S \mathrm{I} .2 . \mathrm{G} .(2) \text { is } \\
\text { demonstrated by having the necessary procedures, } \\
\text { mechanisms, and training in place to effect shutdown or } \\
\text { curtailment of activities which pose an imminent danger } \\
\text { or other serious hazard to workers or the public, or are } \\
\text { not protective of the environment. }\end{array}$ & $\begin{array}{l}\text { The INL-wide procedure addressing problem } \\
\text { identification as required by DOE Manual 435.1-1 } \\
\text { §I.2.G.(1) is LWP-13840, which implements the } \\
\text { laboratory's corrective action system. } \\
\text { The INL-wide procedure addressing shutdown or } \\
\text { curtailment of activities as required by DOE } \\
\text { Manual 435.1-1 } \$ \text { I.2.G.(2) is LWP-14002. }\end{array}$ \\
\hline $\begin{array}{l}\text { (1) Order Compliance. Corrective actions shall be } \\
\text { implemented whenever necessary to ensure the } \\
\text { requirements of DOE O 435.1, Radioactive Waste } \\
\text { Management, and this Manual are met. } \\
\text { From DOE G } 435.1-1 \text { Chapter IV: If a facility or activity } \\
\text { can be allowed to operate while a noncompliant or } \\
\text { hazardous condition exists, the allowance and any } \\
\text { associated limitations must be defined as part of the } \\
\text { facility or activity's radioactive waste management basis, } \\
\text { identified as a configuration controlled item in a } \\
\text { configuration management plan or included in a revision } \\
\text { or modification to an operating procedure or similar } \\
\text { controlled documentation. } \\
\text { Compliance with this requirement is demonstrated if a } \\
\text { corrective action system addresses noncompliant or } \\
\text { hazardous situations involving low-level waste } \\
\text { management facilities in a systematic fashion, and allows } \\
\text { identification of problems by all personnel. }\end{array}$ & See F. above. \\
\hline $\begin{array}{l}\text { (2) Operations Curtailment. Operations shall be curtailed } \\
\text { or facilities shut down for failure to establish, maintain, } \\
\text { or operate consistent with an approved radioactive waste } \\
\text { management basis. } \\
\text { From DOE G } 435.1-1 \text { Chapter IV: Compliance with this } \\
\text { requirement is demonstrated with a documented system }\end{array}$ & $\begin{array}{l}\text { The approved RWMB establishes the current } \\
\text { compliance status at each radioactive waste management } \\
\text { facility. Facility assessments are scheduled to ensure } \\
\text { waste management activities are conducted in } \\
\text { accordance with the approved RWMB. }\end{array}$ \\
\hline
\end{tabular}


Table 7. (continued).

\begin{tabular}{|c|c|}
\hline \multicolumn{2}{|c|}{$\begin{array}{c}\text { Facility Name: TRA-670, ATR Reactor Facility } \\
\text { (includes TRA-605, Warm Waste Treatment Facility, and TRA-1005, Advanced Test Reactor Storage Pad) }\end{array}$} \\
\hline Chapter IV, LLW Requirements & Facility Compliance Information \\
\hline $\begin{array}{l}\text { of routine assessments to determine whether waste } \\
\text { management activities and facilities are operating in } \\
\text { accordance with an approved radioactive waste } \\
\text { management basis that provides for graded limitations } \\
\text { that can be placed on activities and operations that do not } \\
\text { have, or are operating outside of, an approved radioactive } \\
\text { waste management basis, including shutdown of the } \\
\text { facility. }\end{array}$ & \\
\hline $\begin{array}{l}\text { G. Waste Acceptance. The following requirements are in } \\
\text { addition to those in Chapter I of this Manual [DOE M } \\
\text { 435.1-1 §I.2.F(6)]. }\end{array}$ & $\begin{array}{l}\text { Not a facility-specific requirement. DOE Manual 435.1- } \\
1 \S \text { I.2.F(6) applies to field element managers. }\end{array}$ \\
\hline $\begin{array}{l}\text { (1) Technical and Administrative. Waste acceptance } \\
\text { requirements for all low-level waste storage, treatment, } \\
\text { or disposal facilities, operations, and activities shall } \\
\text { specify, at a minimum, the following: }\end{array}$ & $\begin{array}{l}\text { For TRA-670, NA; this facility generates LLW but does } \\
\text { not receive any radioactive waste from other sources. } \\
\text { For TRA-605, NA; this facility generates LLW but does } \\
\text { not receive any radioactive waste from other sources. }\end{array}$ \\
\hline $\begin{array}{l}\text { From DOE G } 435.1-1 \text { Chapter IV: Compliance with } \\
\text { these waste acceptance requirements is demonstrated if } \\
\text { they are documented, contain clear and precise criteria } \\
\text { specifying the radionuclide limits in the form of contents } \\
\text { or concentrations that can be accepted, the limitations } \\
\text { and prohibitions on waste forms and packages that can }\end{array}$ & $\begin{array}{l}\text { For TRA-1005, SAR-153 establishes the facility as a } \\
\text { Hazard Category } 1 \text { nuclear facility and states that } \\
\text { TRA-1005 was considered in this safety basis. SAR-153 } \\
\S \S 1.1 .2 \text { and } 11.5 .3 \text { indicate that TRA-1005 is part of the } \\
\text { ATR facility. }\end{array}$ \\
\hline $\begin{array}{l}\text { be received, and the limits, prohibitions, or instructions } \\
\text { concerning any other technical information so that the } \\
\text { waste is compatible with the safety basis of the facility, } \\
\text { and which will result in acceptable waste at subsequent } \\
\text { steps in managing the low-level waste.) }\end{array}$ & WGS manages LLW in accordance with MCP-17000. \\
\hline $\begin{array}{l}\text { (a) Allowable activities and/or concentrations of specific } \\
\text { radionuclides. }\end{array}$ & See (1) above. \\
\hline $\begin{array}{l}\text { (b) Acceptable waste form and/or container requirements } \\
\text { that ensure the chemical and physical stability of waste } \\
\text { under conditions that might be encountered during } \\
\text { transportation, storage, treatment, or disposal. }\end{array}$ & See (1) above. \\
\hline $\begin{array}{l}\text { (c) Restrictions or prohibitions on waste, materials, or } \\
\text { containers that may adversely affect waste handlers or } \\
\text { compromise facility or waste container performance. }\end{array}$ & See (1) above. \\
\hline $\begin{array}{l}\text { (d) The following are additional waste acceptance } \\
\text { requirements that shall be specified in low-level waste } \\
\text { disposal facility waste acceptance requirements: }\end{array}$ & NA; this facility is not a LLW disposal facility. \\
\hline $\begin{array}{l}1 \text { Low-level waste must contribute to and not detract } \\
\text { from achieving long-term stability of the facility, } \\
\text { minimizing the need for long-term active maintenance, } \\
\text { minimizing subsidence, and minimizing contact of water } \\
\text { with waste. Void spaces within the waste and, if } \\
\text { containers are used, between the waste and its container } \\
\text { shall be reduced to the extent practical. }\end{array}$ & See $(d)$ above. \\
\hline
\end{tabular}


Table 7. (continued).

\begin{tabular}{|c|c|}
\hline \multicolumn{2}{|c|}{$\begin{array}{c}\text { Facility Name: TRA-670, ATR Reactor Facility } \\
\text { (includes TRA-605, Warm Waste Treatment Facility, and TRA-1005, Advanced Test Reactor Storage Pad) }\end{array}$} \\
\hline Chapter IV, LLW Requirements & Facility Compliance Information \\
\hline $\begin{array}{l}2 \text { Liquid low-level waste or low-level waste containing } \\
\text { free liquid must be converted into a form that contains as } \\
\text { little freestanding liquid as is reasonably achievable, but } \\
\text { in no case shall the liquid exceed } 1 \text { percent of the waste } \\
\text { volume when the low-level waste is in a disposal } \\
\text { container, or } 0.5 \text { percent of the waste volume after it is } \\
\text { processed to a stable form. }\end{array}$ & See (d) above. \\
\hline $\begin{array}{l}3 \text { Low-level waste must not be readily capable of } \\
\text { detonation or of explosive decomposition or reaction at } \\
\text { anticipated pressures and temperatures, or of explosive } \\
\text { reaction with water. Pyrophoric materials contained in } \\
\text { waste shall be treated, prepared, and packaged to be } \\
\text { nonflammable. }\end{array}$ & See (d) above. \\
\hline $\begin{array}{l}4 \text { Low-level waste must not contain, or be capable of } \\
\text { generating by radiolysis or biodegradation, quantities of } \\
\text { toxic gases, vapors, or fumes harmful to the public or } \\
\text { workers or disposal facility personnel, or harmful to the } \\
\text { long-term structural stability of the disposal site. }\end{array}$ & See (d) above. \\
\hline $\begin{array}{l}5 \text { Low-level waste in a gaseous form must be packaged } \\
\text { such that the pressure does not exceed } 1.5 \text { atmospheres } \\
\text { absolute at } 20 \mathrm{C} \text {. [ sic ] }\end{array}$ & See (d) above. \\
\hline $\begin{array}{l}\text { (e) The basis, procedures, and levels of authority } \\
\text { required for granting exceptions to the waste acceptance } \\
\text { requirements, which shall be contained in each facility's } \\
\text { waste acceptance documentation. Each exception request } \\
\text { shall be documented, including its disposition as } \\
\text { approved or not approved. }\end{array}$ & $\begin{array}{l}\text { NA; this facility is a Hazard Category } 1 \text { nuclear facility. } \\
\text { Therefore, radioactive material inventory limits are not } \\
\text { tracked for this facility. }\end{array}$ \\
\hline $\begin{array}{l}\text { From DOE G } 435.1-1 \text { Chapter IV: Waste acceptance } \\
\text { requirements are acceptable if they are documented and } \\
\text { contain a clear description of the procedure and bases for } \\
\text { obtaining an exception or deviation to the acceptance } \\
\text { criteria for low-level waste to be received at the facility. }\end{array}$ & \\
\hline $\begin{array}{l}\text { (2) Evaluation and Acceptance. The receiving facility } \\
\text { shall evaluate waste for acceptance, including } \\
\text { confirmation that the technical and administrative } \\
\text { requirements have been met. A process for the } \\
\text { disposition of non-conforming wastes shall be } \\
\text { established. }\end{array}$ & $\begin{array}{l}\text { NA; this facility is a Hazard Category } 1 \text { nuclear facility. } \\
\text { Therefore, radioactive material inventory limits are not } \\
\text { tracked for this facility. }\end{array}$ \\
\hline $\begin{array}{l}\text { Compliance with the waste acceptance requirements for } \\
\text { a low-level waste management facility is demonstrated if } \\
\text { they include a process for evaluation and acceptance of } \\
\text { incoming waste to ensure the acceptance criteria of the } \\
\text { facility receiving the waste are met that includes one of } \\
\text { or a combination of: (1) testing, sampling, and analysis } \\
\text { of representative samples of waste upon receipt; (2) } \\
\text { testing, sampling, and analysis of split samples of waste }\end{array}$ & \\
\hline
\end{tabular}


Table 7. (continued).

\begin{tabular}{|c|c|}
\hline $\begin{array}{l}\text { Facility Name: TRA-670 } \\
\text { (includes TRA-605, Warm Waste Treatment Facility, }\end{array}$ & $\begin{array}{l}\text { 0, ATR Reactor Facility } \\
\text { and TRA-1005, Advanced Test Reactor Storage Pad) }\end{array}$ \\
\hline Chapter IV, LLW Requirements & Facility Compliance Information \\
\hline $\begin{array}{l}\text { taken at the generator site; (3) evaluation of testing, } \\
\text { sampling, and analysis of data provided by the generator, } \\
\text { or (4) audits, reviews, surveillance, or observations of } \\
\text { generator waste certification programs and } \\
\text { characterization activities. Additionally, acceptable waste } \\
\text { acceptance requirements for a storage, treatment or } \\
\text { disposal facility will have documented procedures and } \\
\text { actions to be taken if a waste that does not conform to the } \\
\text { waste acceptance criteria is received at the facility. }\end{array}$ & \\
\hline $\begin{array}{l}\text { H. Waste Generation Planning. The following } \\
\text { requirements are in addition to those in Chapter I of this } \\
\text { Manual [DOE M 435.1-1 §I.2.F(7)]. }\end{array}$ & $\begin{array}{l}\text { Not a facility-specific requirement. DOE Manual 435.1- } \\
1 \text { §I.2.F(7) applies to field element managers. }\end{array}$ \\
\hline $\begin{array}{l}\text { (1) Life-Cycle Planning. Prior to waste generation, } \\
\text { planning shall be performed to address the entire life } \\
\text { cycle for all low-level waste streams. }\end{array}$ & $\begin{array}{l}\text { PDD- } 17000 \text { and LWP- } 17000 \text { provide direction to the } \\
\text { waste generators for waste generation planning to } \\
\text { address the entire life cycle. }\end{array}$ \\
\hline $\begin{array}{l}\text { From DOE G 435.1-1 Chapter IV: Compliance with this } \\
\text { planning requirement is demonstrated by the individual } \\
\text { sites establishing a process for evaluating the life-cycle } \\
\text { of low-level waste prior to its generation, including the } \\
\text { identification of low-level wastes with no path to } \\
\text { disposal and appropriate records justifying the newly } \\
\text { generated low-level waste stream(s), and site personnel } \\
\text { possessing planning information showing the location(s) } \\
\text { where low-level waste will be stored, treated, and/or } \\
\text { disposed along with a confirmation that the personnel } \\
\text { managing the facilities agree that the low-level waste } \\
\text { may be managed at those facilities. }\end{array}$ & \\
\hline $\begin{array}{l}\text { (2) Waste with No Identified Path to Disposal. Low-level } \\
\text { waste streams with no identified path to disposal shall be } \\
\text { generated only in accordance with approved conditions } \\
\text { which, at a minimum, shall address: }\end{array}$ & $\begin{array}{l}\text { This facility is not generating radioactive waste that does } \\
\text { not have an identified path to disposal. }\end{array}$ \\
\hline (a) Programmatic need to generate the waste; & See (2) above. \\
\hline $\begin{array}{l}\text { (b) Characteristics and issues preventing the disposal of } \\
\text { the waste; }\end{array}$ & See (2) above. \\
\hline $\begin{array}{l}\text { (c) Safe storage of the waste until disposal can be } \\
\text { achieved; and }\end{array}$ & See (2) above. \\
\hline $\begin{array}{l}\text { (d) Activities and plans for achieving final disposal of } \\
\text { the waste. }\end{array}$ & See (2) above. \\
\hline $\begin{array}{l}\text { I. Waste Characterization. Low-level waste shall be } \\
\text { characterized using direct or indirect methods, and the } \\
\text { characterization documented in sufficient detail to ensure } \\
\text { safe management and compliance with the waste } \\
\text { acceptance requirements of the facility receiving the } \\
\text { waste. } \\
\text { From DOE G 435.1-1 Chapter IV: Compliance with this }\end{array}$ & $\begin{array}{l}\text { MCP-17000 addresses waste characterization. } \\
\text { For the liquid LLW generated at TRA-605, } \\
\text { OMM-7.11.13.8.1 } \S 3.6 \text { and Appendix A provide the } \\
\text { guidelines and liquid effluent concentration limits to be } \\
\text { met prior to the transfer of TRA-605 contents to } \\
\text { TRA-715, Evaporation Ponds. }\end{array}$ \\
\hline
\end{tabular}


Table 7. (continued).

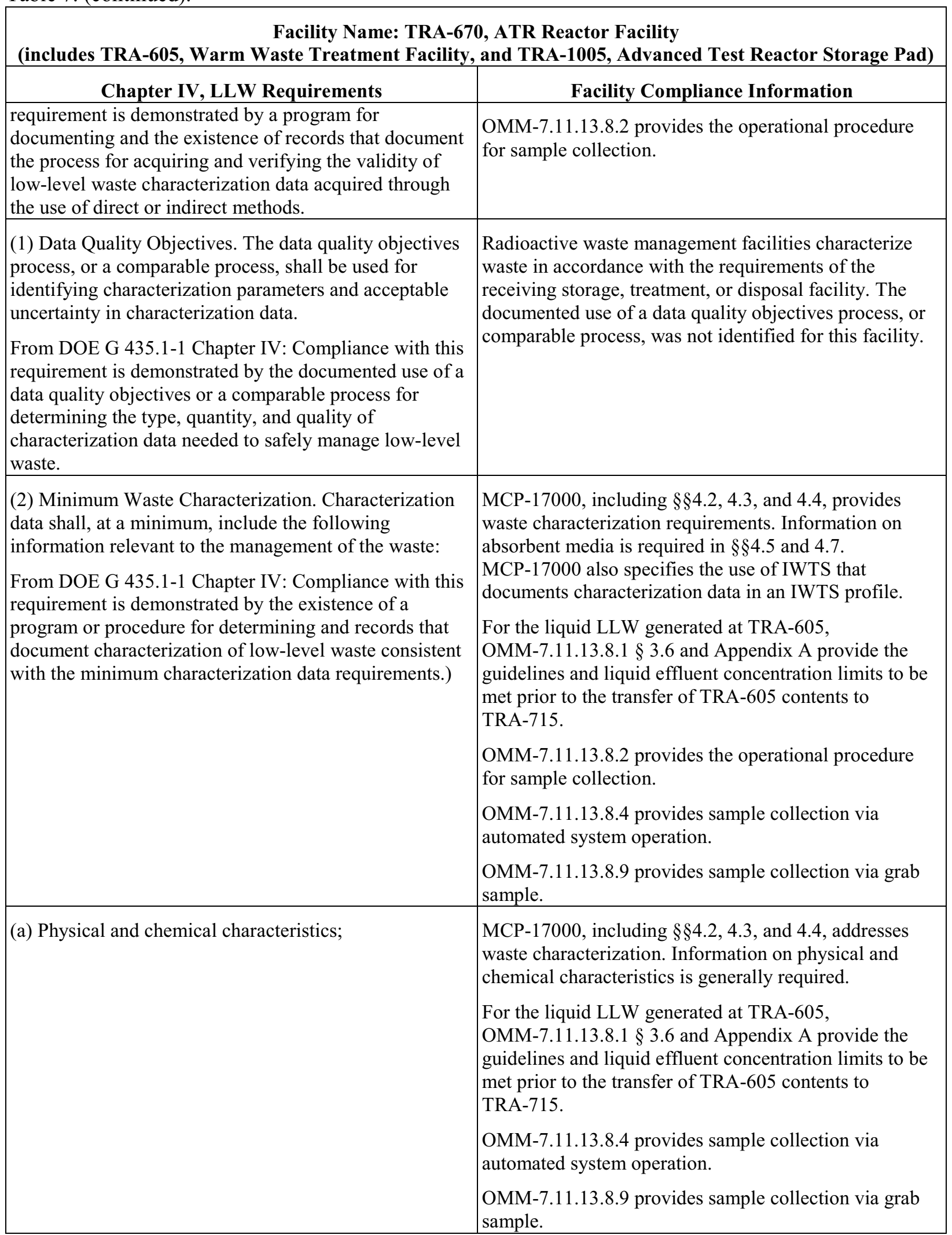


Table 7. (continued).

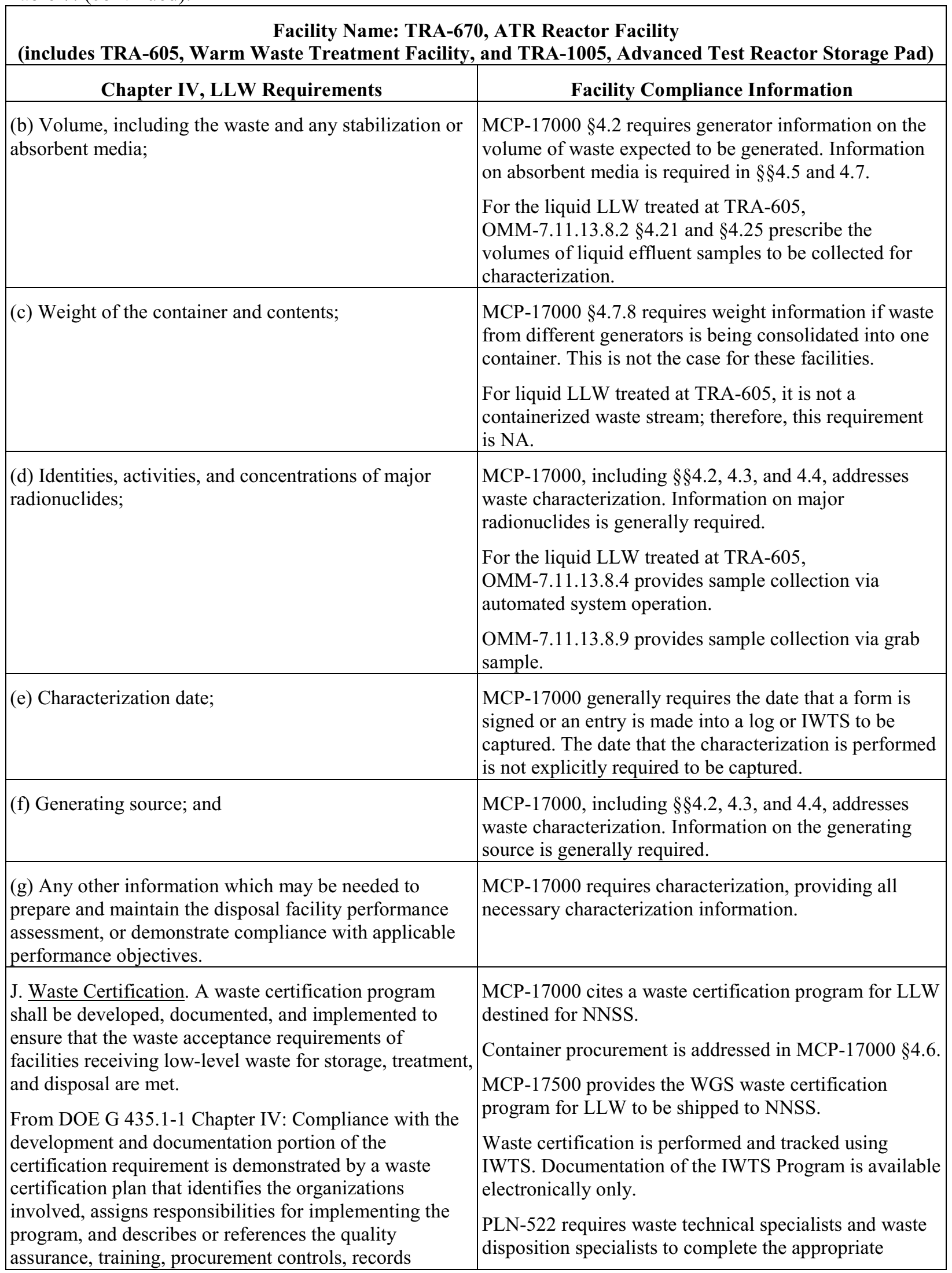


Table 7. (continued).

\begin{tabular}{|c|c|}
\hline \multicolumn{2}{|c|}{$\begin{array}{l}\text { Facility Name: TRA-670, ATR Reactor Facility } \\
\text { (includes TRA-605, Warm Waste Treatment Facility, and TRA-1005, Advanced Test Reactor Storage Pad) }\end{array}$} \\
\hline Chapter IV, LLW Requirements & Facility Compliance Information \\
\hline $\begin{array}{l}\text { management, and procedures to be used by the program. } \\
\text { Acceptable performance for implementing the program is } \\
\text { demonstrated when appropriate personnel are trained and } \\
\text { follow the procedures that govern their part of the waste } \\
\text { certification. Additionally, acceptable performance is } \\
\text { demonstrated if the waste certification plan and } \\
\text { procedures are current and controlled in accordance with } \\
\text { a document controls program, and records related to } \\
\text { certification (e.g., certification statements, training } \\
\text { records, procurement records, characterization records, } \\
\text { container records) are generated and managed in } \\
\text { accordance with the established site program. }\end{array}$ & $\begin{array}{l}\text { training/qualification before being granted approval } \\
\text { authority for profiles within the IWTS Program. The } \\
\text { waste certification official, alternate waste certification } \\
\text { official, and NNSS packaging certifiers must complete } \\
\text { the appropriate training/qualifications to disposition } \\
\text { waste to NNSS. }\end{array}$ \\
\hline $\begin{array}{l}\text { (1) Certification Program. The waste certification } \\
\text { program shall designate the officials who have the } \\
\text { authority to certify and release waste for shipment; and } \\
\text { specify what documentation is required for waste } \\
\text { generation, characterization, shipment, and certification. } \\
\text { The program shall provide requirements for auditability, } \\
\text { retrievability, and storage of required documentation and } \\
\text { specify the records retention period. }\end{array}$ & $\begin{array}{l}\text { See J. above. MCP- } 17500 \S \S 2 \text { and } 5 \text { address } \\
\text { certification records for shipments to NNSS. }\end{array}$ \\
\hline $\begin{array}{l}\text { From DOE G } 435.1-1 \text { Chapter IV: Compliance with this } \\
\text { requirement is demonstrated by a program or procedure } \\
\text { for record keeping and records showing that low-level } \\
\text { waste is certified as having met the waste acceptance } \\
\text { criteria of the facility to which it was transferred and that } \\
\text { the certification statement is supported by additional } \\
\text { records regarding the waste source, characterization, and } \\
\text { container. }\end{array}$ & \\
\hline $\begin{array}{l}\text { (2) Certification before Transfer. Low-level waste shall } \\
\text { be certified as meeting waste acceptance requirements } \\
\text { before it is transferred to the facility receiving the waste. }\end{array}$ & $\begin{array}{l}\text { See J. above. MCP- } 17500 \S 4.3 .6 \text { addresses controls for } \\
\text { certification before transfer for LLW to be disposed of at } \\
\text { NNSS. }\end{array}$ \\
\hline $\begin{array}{l}\text { From DOE G } 435.1-1 \text { Chapter IV: Compliance with this } \\
\text { requirement is demonstrated by the presence of a } \\
\text { certification program which includes procedures } \\
\text { requiring a signed certification statement prior to the } \\
\text { release of waste for transfer, and by dated records } \\
\text { showing that waste was certified before being } \\
\text { transferred. }\end{array}$ & \\
\hline $\begin{array}{l}\text { (3) Maintaining Certification. Low-level waste that has } \\
\text { been certified as meeting the waste acceptance } \\
\text { requirements for transfer to a storage, treatment, or } \\
\text { disposal facility shall be managed in a manner that } \\
\text { maintains its certification status. } \\
\text { From DOE G } 435.1-1 \text { Chapter IV: Compliance with this } \\
\text { requirement is demonstrated by a program or procedure } \\
\text { reflecting this requirement is present and site personnel } \\
\text { are able to show that the storage of low-level waste }\end{array}$ & $\begin{array}{l}\text { See J. above. Pre-certification checklists are cited in } \\
\text { MCP- } 17000 \text { and MCP-17500. Surveillances also are } \\
\text { addressed in MCP-17500. } \\
\text { LWP-15011 } \$ 5 \text { provides general radioactive storage area } \\
\text { requirements and } \$ 5.1 .7 \text { addresses outdoor storage of } \\
\text { radioactive material. }\end{array}$ \\
\hline
\end{tabular}


Table 7. (continued).

\begin{tabular}{|c|c|}
\hline \multicolumn{2}{|c|}{$\begin{array}{c}\text { Facility Name: TRA-670, ATR Reactor Facility } \\
\text { (includes TRA-605, Warm Waste Treatment Facility, and TRA-1005, Advanced Test Reactor Storage Pad) }\end{array}$} \\
\hline Chapter IV, LLW Requirements & Facility Compliance Information \\
\hline $\begin{array}{l}\text { containers is in a facility or manner where the containers } \\
\text { would not be damaged by normal weather events, and } \\
\text { cannot be accessed by unauthorized personnel. Further, } \\
\text { each container can be traced to its certification and the } \\
\text { information supporting that certification. }\end{array}$ & \\
\hline $\begin{array}{l}\text { K. Waste Transfer. A documented process shall be } \\
\text { established and implemented for transferring } \\
\text { responsibility for management of low-level waste and for } \\
\text { ensuring availability of relevant data. The following } \\
\text { requirements are in addition to those in Chapter I of this } \\
\text { Manual. }\end{array}$ & $\begin{array}{l}\text { MCP-17000 } \$ 4.8 .15 \text { specifies requirements for } \\
\text { interfacility transfers. } \\
\text { MCP-17500 } \S 4 \text { addresses LLW to be transferred to } \\
\text { NNSS. }\end{array}$ \\
\hline $\begin{array}{l}\text { From DOE G } 435.1-1 \text { Chapter IV: Compliance with this } \\
\text { requirement is demonstrated if facilities have procedures } \\
\text { for the receipt of waste and the transfer of waste, as } \\
\text { appropriate, which address the acquisition of waste and } \\
\text { container data and the transfer of ownership, } \\
\text { respectively. Further evidence of acceptable performance } \\
\text { is facility records showing that data on the waste } \\
\text { containers is available and accurate, and that documented } \\
\text { transfer of responsibility occurs. }\end{array}$ & \\
\hline $\begin{array}{l}\text { (1) Authorization. Low-level waste shall not be } \\
\text { transferred to a storage, treatment, or disposal facility } \\
\text { until personnel responsible for the facility receiving the } \\
\text { waste authorize the transfer. }\end{array}$ & See K. above. \\
\hline $\begin{array}{l}\text { From DOE G } 435.1-1 \text { Chapter IV: Compliance with this } \\
\text { requirement is demonstrated by sites having procedures } \\
\text { that require a confirmation of authorization before } \\
\text { releasing waste for transfer, and records showing that } \\
\text { transfers are made in accordance with written } \\
\text { authorizations. }\end{array}$ & \\
\hline $\begin{array}{l}\text { (2) Data. Waste characterization data, container } \\
\text { information, and generation, storage, treatment, and } \\
\text { transportation information for low-level waste shall be } \\
\text { transferred with or be traceable to the waste. }\end{array}$ & See K. above. \\
\hline $\begin{array}{l}\text { From DOE G } 435.1-1 \text { Chapter IV: Compliance with this } \\
\text { requirement is demonstrated if there are procedures } \\
\text { requiring that characterization and container data be } \\
\text { provided and maintained for each low-level waste } \\
\text { transfer and documented records of transfers show that } \\
\text { the information is being provided. }\end{array}$ & \\
\hline $\begin{array}{l}\text { L. Packaging and Transportation. The following } \\
\text { requirements are in addition to those in Chapter I of this } \\
\text { Manual [DOE M 435.1-1 } \S \text { I.1.E(11)]. }\end{array}$ & $\begin{array}{l}\text { Not a facility-specific requirement. DOE Manual 435.1- } \\
1 \text { §I.1.E(11) applies to field element managers. }\end{array}$ \\
\hline (1) Packaging. If containers are used: & MCP-17000 $\S 4$ addresses packaging requirements. \\
\hline $\begin{array}{l}\text { From DOE G 435.1-1 Chapter IV: Compliance with the } \\
\text { packaging requirement is demonstrated by: (1) }\end{array}$ & $\begin{array}{l}\text { For the liquid LLW treated at TRA- } 605 \text {, it is not a } \\
\text { containerized waste stream; therefore, this requirement }\end{array}$ \\
\hline
\end{tabular}


Table 7. (continued).

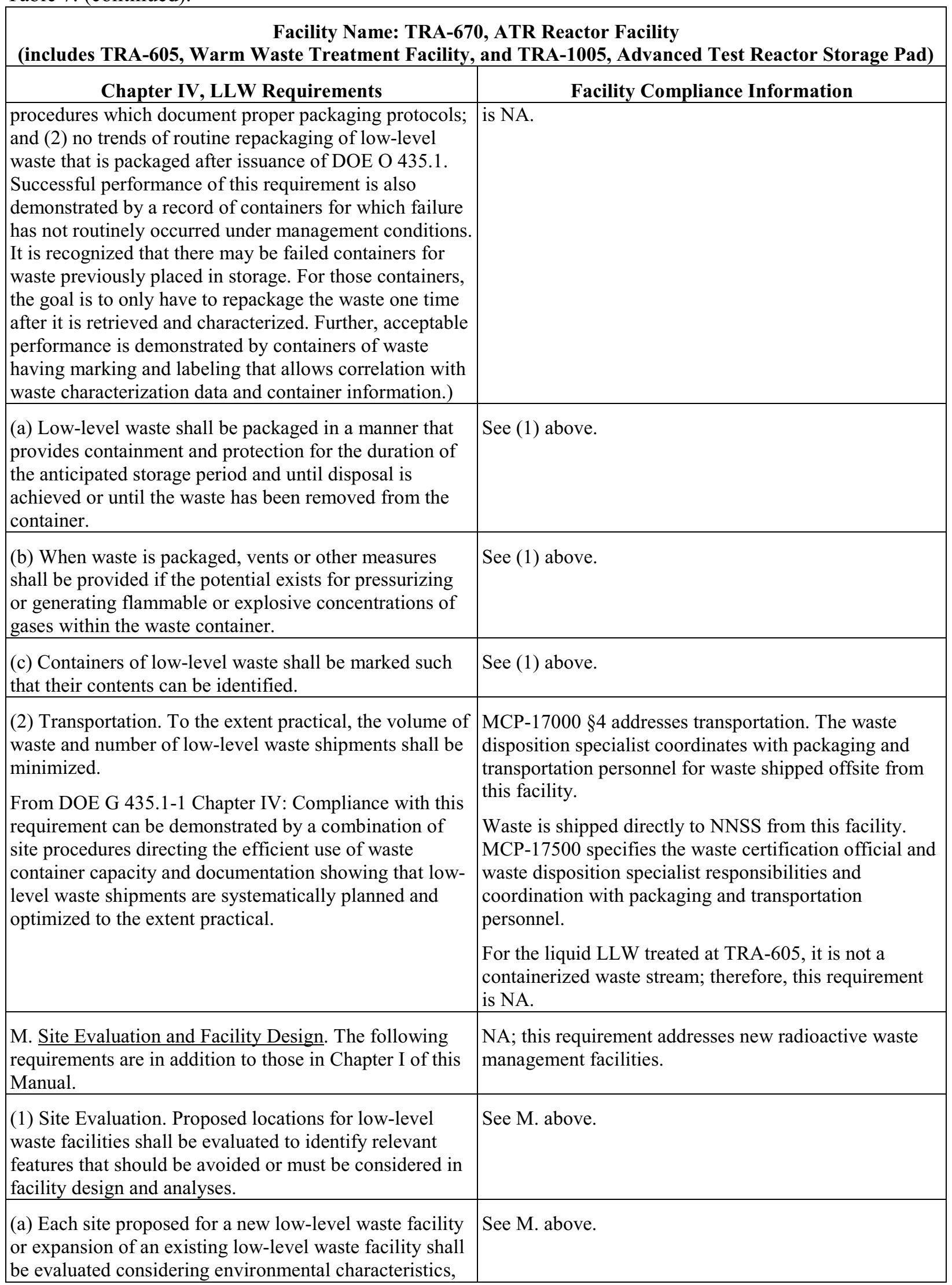


Table 7. (continued).

\begin{tabular}{|c|c|}
\hline $\begin{array}{r}\text { Facility Name: TRA-670 } \\
\text { (includes TRA-605, Warm Waste Treatment Facility, }\end{array}$ & $\begin{array}{l}\text { 0, ATR Reactor Facility } \\
\text { and TRA-1005, Advanced Test Reactor Storage Pad) }\end{array}$ \\
\hline Chapter IV, LLW Requirements & Facility Compliance Information \\
\hline $\begin{array}{l}\text { geotechnical characteristics, and human activities, } \\
\text { including for a low-level waste disposal facility, the } \\
\text { capability of the site to demonstrate, at a minimum, } \\
\text { whether it is: }\end{array}$ & \\
\hline $\begin{array}{l}1 \text { Located to accommodate the projected volume of } \\
\text { waste to be received; }\end{array}$ & See M. above. \\
\hline $\begin{array}{l}2 \text { Located in a flood plain, a tectonically active area, or } \\
\text { in the zone of water table fluctuation; and }\end{array}$ & See M. above. \\
\hline $\begin{array}{l}3 \text { Located where radionuclide migration pathways are } \\
\text { predictable and erosion and surface runoff can be } \\
\text { controlled. }\end{array}$ & See M. above. \\
\hline $\begin{array}{l}\text { (b) Proposed sites with environmental characteristics, } \\
\text { geotechnical characteristics, and human activities for } \\
\text { which adequate protection cannot be provided through } \\
\text { facility design shall be deemed unsuitable for the } \\
\text { location of the facility. }\end{array}$ & See M. above. \\
\hline $\begin{array}{l}\text { (c) Low-level waste disposal facilities shall be sited to } \\
\text { achieve long-term stability and to minimize, to the extent } \\
\text { practical, the need for active maintenance following final } \\
\text { closure. }\end{array}$ & See M. above. \\
\hline $\begin{array}{l}\text { (2) Low-Level Waste Treatment and Storage Facility } \\
\text { Design. The following facility requirements and general } \\
\text { design criteria, at a minimum, apply: }\end{array}$ & See M. above. \\
\hline $\begin{array}{l}\text { (a) Confinement. Low-level waste systems and } \\
\text { components shall be designed to maintain waste } \\
\text { confinement. }\end{array}$ & See M. above. \\
\hline (b) Ventilation. & See M. above. \\
\hline $\begin{array}{l}1 \text { Design of low-level waste treatment and storage } \\
\text { facilities shall include ventilation, if applicable, through } \\
\text { an appropriate filtration system to maintain the release of } \\
\text { radioactive material in airborne effluents within the } \\
\text { requirements and guidelines specified in applicable } \\
\text { requirements. }\end{array}$ & See M. above. \\
\hline $\begin{array}{l}2 \text { When conditions exist for generating gases in } \\
\text { flammable or explosive concentrations, ventilation } \\
\text { systems or other measures shall be provided to keep the } \\
\text { gases in a non-flammable and nonexplosive condition. } \\
\text { Where concentrations of explosive or flammable gases } \\
\text { are expected to approach the lower flammability limit, } \\
\text { measures shall be taken to prevent deflagration or } \\
\text { detonation. }\end{array}$ & See M. above. \\
\hline $\begin{array}{l}\text { (c) Consideration of Decontamination and } \\
\text { Decommissioning. Areas in new and modifications to } \\
\text { existing low-level waste management facilities that are }\end{array}$ & See M. above. \\
\hline
\end{tabular}


Table 7. (continued).

\begin{tabular}{|c|c|}
\hline $\begin{array}{r}\text { Facility Name: TRA-67 } \\
\text { (includes TRA-605, Warm Waste Treatment Facility, }\end{array}$ & $\begin{array}{l}\text { 0, ATR Reactor Facility } \\
\text { and TRA-1005, Advanced Test Reactor Storage Pad }\end{array}$ \\
\hline Chapter IV, LLW Requirements & Facility Compliance Information \\
\hline $\begin{array}{l}\text { subject to contamination with radioactive or other } \\
\text { hazardous materials shall be designed to facilitate } \\
\text { decontamination. For such facilities a proposed } \\
\text { decommissioning method or a conversion method } \\
\text { leading to reuse shall be described. }\end{array}$ & \\
\hline $\begin{array}{l}\text { (d) Instrumentation and Control Systems. Engineering } \\
\text { controls shall be incorporated in the design and } \\
\text { engineering of low-level waste treatment and storage } \\
\text { facilities to provide volume inventory data and to prevent } \\
\text { spills, leaks, and overflows from tanks or confinement } \\
\text { systems. }\end{array}$ & See M. above. \\
\hline $\begin{array}{l}\text { (e) Monitoring. Monitoring and/or leak detection } \\
\text { capabilities shall be incorporated in the design and } \\
\text { engineering of low-level waste treatment and storage } \\
\text { facilities to provide rapid identification of failed } \\
\text { confinement and/or other abnormal conditions. }\end{array}$ & See M. above. \\
\hline $\begin{array}{l}\text { (3) Low-Level Waste Disposal Facility Design. The } \\
\text { following facility requirements and general design } \\
\text { criteria, at a minimum, apply: }\end{array}$ & See M. above. \\
\hline $\begin{array}{l}\text { (a) Confinement. Low-level waste systems and } \\
\text { components shall be designed to maintain waste } \\
\text { confinement. }\end{array}$ & See M. above. \\
\hline (b) Ventilation. & See M. above. \\
\hline $\begin{array}{l}1 \text { Design of low-level waste disposal facilities shall } \\
\text { include ventilation, if applicable, through an appropriate } \\
\text { filtration system to maintain the release of radioactive } \\
\text { material in airborne effluents within the requirements } \\
\text { and guidelines specified in applicable requirements. }\end{array}$ & See M. above. \\
\hline $\begin{array}{l}2 \text { When conditions exist for generating gases in } \\
\text { flammable or explosive concentrations, ventilation } \\
\text { systems or other measures shall be provided to keep the } \\
\text { gases in a nonflammable and non-explosive condition. } \\
\text { Where concentrations of explosive or flammable gases } \\
\text { are expected to approach the lower flammability limit, } \\
\text { measures shall be taken to prevent deflagration or } \\
\text { detonation. }\end{array}$ & See M. above. \\
\hline $\begin{array}{l}\text { (c) Stability. Low-level waste disposal facilities shall be } \\
\text { designed to achieve long-term stability and to minimize } \\
\text { to the extent practical, the need for active maintenance } \\
\text { following final closure. }\end{array}$ & See M. above. \\
\hline $\begin{array}{l}\text { (d) Control of Water. Low-level waste disposal facilities } \\
\text { shall be designed to minimize to the extent practical, the } \\
\text { contact of waste with water during and after disposal. }\end{array}$ & See M. above. \\
\hline
\end{tabular}


Table 7. (continued).

\begin{tabular}{|c|c|}
\hline \multicolumn{2}{|c|}{$\begin{array}{l}\text { Facility Name: TRA-670, ATR Reactor Facility } \\
\text { (includes TRA-605, Warm Waste Treatment Facility, and TRA-1005, Advanced Test Reactor Storage Pad) }\end{array}$} \\
\hline Chapter IV, LLW Requirements & Facility Compliance Information \\
\hline $\begin{array}{l}\text { N. Storage and Staging. The following requirements are } \\
\text { in addition to those in Chapter I of this Manual [DOE M } \\
435.1-1 \S \text { I.2.F(13)]. }\end{array}$ & $\begin{array}{l}\text { Not a facility-specific requirement. DOE Manual 435.1- } \\
1 \text { §I.2.F(13) applies to field element managers. }\end{array}$ \\
\hline $\begin{array}{l}\text { (1) Storage Prohibitions. Low-level waste in storage shall } \\
\text { not be readily capable of detonation, explosive } \\
\text { decomposition, reaction at anticipated pressures and } \\
\text { temperatures, or explosive reaction with water. Prior to } \\
\text { storage, pyrophoric materials shall be treated, prepared, } \\
\text { and packaged to be nonflammable. } \\
\text { From DOE G } 435.1-1 \text { Chapter IV: Compliance with this } \\
\text { requirement is demonstrated by having waste acceptance } \\
\text { requirements which prohibit low-level waste that is } \\
\text { ignitable or explosive from being accepted for storage } \\
\text { unless it has been treated, and procedures for properly } \\
\text { preparing such materials for safe storage. }\end{array}$ & $\begin{array}{l}\text { For TRA-670, a facility-specific procedure addressing } \\
\text { this requirement was not identified. } \\
\text { For TRA-605, NA; this facility does not store LLW. See } \\
\text { N. (7) below for staging requirements. } \\
\text { For TRA-1005, a facility-specific procedure addressing } \\
\text { this requirement was not identified. } \\
\text { However, the NNSS waste acceptance criteria does not } \\
\text { allow such waste (MCP-17500); therefore, such waste } \\
\text { would not be stored at this facility. }\end{array}$ \\
\hline $\begin{array}{l}\text { (2) Storage Limit. Low-level waste that has an identified } \\
\text { path to disposal shall not be stored longer than one year } \\
\text { prior to disposal, except for storage for decay, or as } \\
\text { otherwise authorized by the Field Element Manager. } \\
\text { From DOE G } 435.1 \text {-1 Chapter IV: Storage longer than } \\
\text { one year can be justified if the conditions for such } \\
\text { storage are approved by the Field Element Manager as } \\
\text { part of the radioactive waste management basis for the } \\
\text { facility. } \\
\text { Storage for radioactive decay for a period greater than } 1 \\
\text { year for waste that has an identified path to disposal is } \\
\text { allowed. Adequate justification and the supporting } \\
\text { information for storage for decay is to be documented in } \\
\text { the radioactive waste management basis for the facility in } \\
\text { which the storage will take place. } \\
\text { Mixed waste. Under the Federal Facility Compliance Act } \\
\text { of } 1992 \text {, DOE sites were required to develop Site } \\
\text { Treatment Plans to bring stored mixed low-level waste } \\
\text { into compliance with these requirements. The Site } \\
\text { Treatment Plan needs to be consulted and any mixed } \\
\text { low-level waste stored for the purpose of accumulation to } \\
\text { facilitate treatment must meet Resource Conservation } \\
\text { and Recovery Act storage requirements. There could be } \\
\text { several ways within different scenarios that this } \\
\text { requirement can be met, as illustrated by the examples } \\
\text { below, however, there are basically four ways to show } \\
\text { compliance with the requirement and include appropriate } \\
\text { provisions in the radioactive waste management basis for } \\
\text { the facility in which it is stored. } \\
\text { Legacy waste. As discussed above, the intention of the } \\
\text { requirement is not to force malicious compliance or }\end{array}$ & $\begin{array}{l}\text { For TRA-605, NA; this facility does not store LLW. See } \\
\text { N. (7) below for staging requirements. } \\
\text { For TRA-1005, MCP-17000 } \$ 4.8 .16 \text { addresses storage } \\
\text { time limits and waste that is to be stored longer than } \\
1 \text { year. Legacy remote-handled LLW is stored at this } \\
\text { facility. } \\
\text { COMPLIANCE CONSIDERATION } \\
\text { For TRA- } 670 \text { and TRA-1005, BEA will include a } \\
\text { justification for storage longer than } 1 \text { year in the RWMB } \\
\text { because the waste is remote-handled legacy LLW. }\end{array}$ \\
\hline
\end{tabular}


Table 7. (continued).

\begin{tabular}{|c|c|}
\hline \multicolumn{2}{|c|}{$\begin{array}{l}\text { Facility Name: TRA-670, ATR Reactor Facility } \\
\text { (includes TRA-605, Warm Waste Treatment Facility, and TRA-1005, Advanced Test Reactor Storage Pad) }\end{array}$} \\
\hline Chapter IV, LLW Requirements & Facility Compliance Information \\
\hline $\begin{array}{l}\text { heroic actions which would result in increased risk or } \\
\text { safety concerns. Rather, the intention is that waste in } \\
\text { storage longer than one year receives additional attention } \\
\text { to ensure that the public, the workers, and the } \\
\text { environment are protected from the hazards of the waste, } \\
\text { and that progress is being made to dispose of the waste. } \\
\text { There could be several ways within different scenarios } \\
\text { that this requirement can be met, as illustrated by the } \\
\text { examples below, however, there are basically four ways } \\
\text { to show compliance with the requirement: }\end{array}$ & \\
\hline $\begin{array}{l}\text { 1) the radioactive waste management basis allows for } \\
\text { storage for no more than one year. }\end{array}$ & \\
\hline $\begin{array}{l}\text { 2) the radioactive waste management basis allows for } \\
\text { storage for no more than one year, or for storage for } \\
\text { decay only for periods greater than a year, which are } \\
\text { specified on a radionuclide basis. }\end{array}$ & \\
\hline $\begin{array}{l}\text { 3) the radioactive waste management basis allows for } \\
\text { storage for more than one year, up to a specified period } \\
\text { of time based on a documented technical evaluation that } \\
\text { the waste can be stored in a manner that does not cause } \\
\text { changes to the waste or waste packages that is } \\
\text { detrimental to the safe storage of the waste, the final } \\
\text { disposal of the waste or to meeting the disposal } \\
\text { performance objectives. }\end{array}$ & \\
\hline $\begin{array}{l}\text { 4) the radioactive waste management basis allows for } \\
\text { storage for decay (with specifics) and for storage for } \\
\text { more than one year for other low-level waste, up to a } \\
\text { specified period of time based on a documented technical } \\
\text { evaluation that the waste can be stored in a manner that } \\
\text { does not cause changes to the waste or waste packages } \\
\text { that is detrimental to the safe storage of the waste, the } \\
\text { final disposal of the waste or to meeting the disposal } \\
\text { performance objectives. }\end{array}$ & \\
\hline $\begin{array}{l}\text { Compliance with this requirement is demonstrated by the } \\
\text { existence of a radioactive waste management basis for } \\
\text { the storage facility approved by the Field Element } \\
\text { Manager that includes the time frames that waste are } \\
\text { allowed to be stored, the necessary justifications for } \\
\text { storage for decay, and the necessary technical } \\
\text { evaluations if storage is to extend significantly beyond } \\
\text { the one-year time frame. }\end{array}$ & \\
\hline $\begin{array}{l}\text { (3) Storage Integrity. Low-level waste shall be stored in a } \\
\text { location and manner that protects the integrity of waste }\end{array}$ & $\begin{array}{l}\text { For TRA- } 670, \mathrm{LWP}-15011 \S 5 \text { provides general } \\
\text { radioactive storage area requirements. }\end{array}$ \\
\hline $\begin{array}{l}\text { for the expected time of storage and minimizes worker } \\
\text { exposure. }\end{array}$ & $\begin{array}{l}\text { For TRA-605, NA, this facility does not store LLW. See } \\
\text { N. (7) below for staging requirements. }\end{array}$ \\
\hline $\begin{array}{l}\text { From DOE G } 435.1-1 \text { Chapter IV: However, in making a } \\
\text { decision to use a facility for storage and in developing a }\end{array}$ & For TRA-670, LWP-15011 §5 provides general \\
\hline
\end{tabular}


Table 7. (continued).

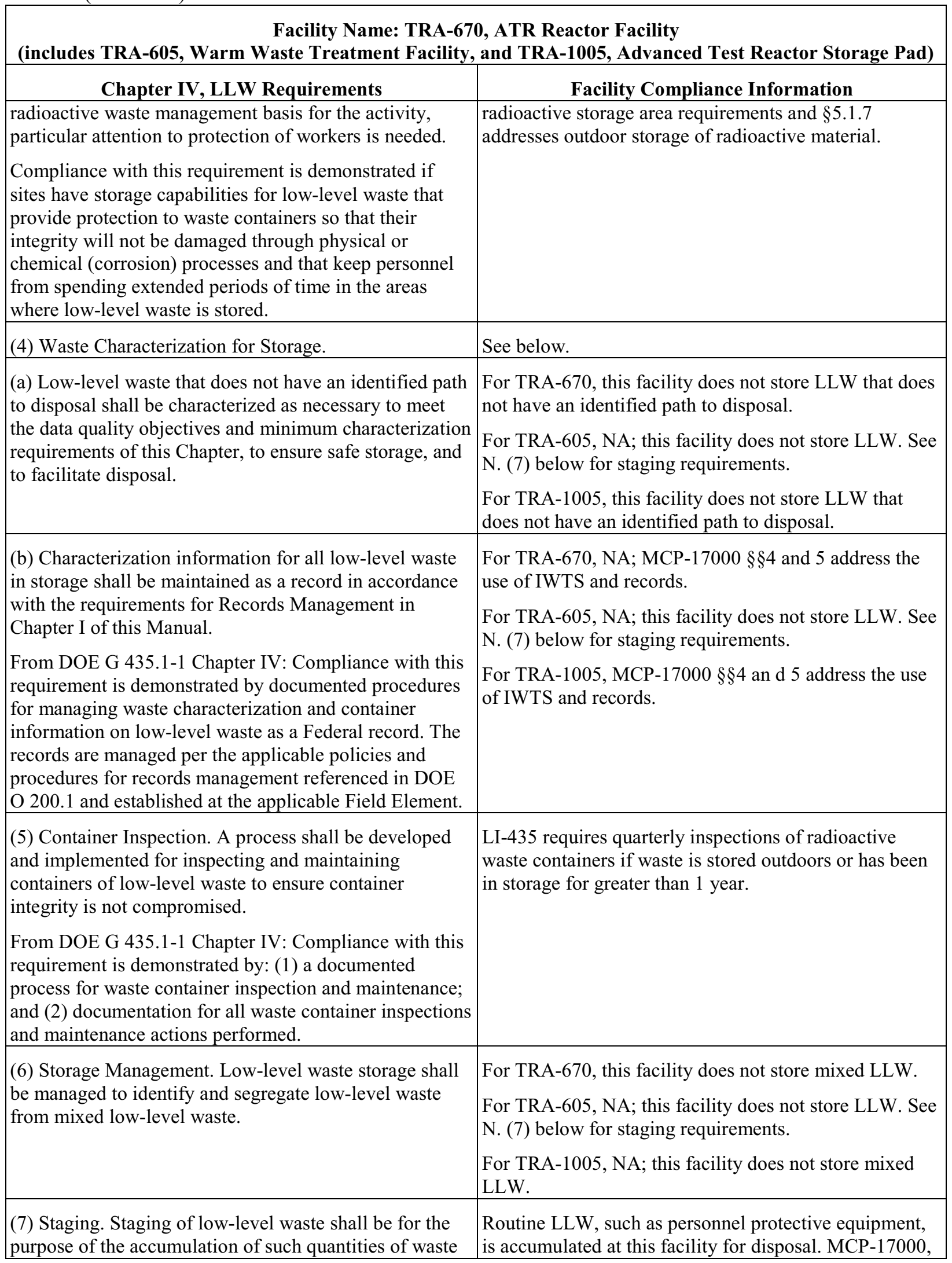


Table 7. (continued).

\begin{tabular}{|c|c|}
\hline \multicolumn{2}{|c|}{$\begin{array}{c}\text { Facility Name: TRA-670, ATR Reactor Facility } \\
\text { (includes TRA-605, Warm Waste Treatment Facility, and TRA-1005, Advanced Test Reactor Storage Pad) }\end{array}$} \\
\hline Chapter IV, LLW Requirements & Facility Compliance Information \\
\hline $\begin{array}{l}\text { as necessary to facilitate transportation, treatment, and } \\
\text { disposal. Staging longer than } 90 \text { days shall meet the } \\
\text { requirements for storage above and in Chapter I of this } \\
\text { Manual. }\end{array}$ & $\begin{array}{l}\text { Appendix F, "Container Start Date and Storage } \\
\text { Prohibitions," restricts staging LLW to } 90 \text { days } \\
\text { maximum at any generator or treatment facility prior to } \\
\text { acceptance by a storage facility. }\end{array}$ \\
\hline $\begin{array}{l}\text { From DOE G } 435.1-1 \text { Chapter IV: The staging of low- } \\
\text { level waste needs to be addressed in the radioactive } \\
\text { waste management basis for the facility that is } \\
\text { performing the staging. Generators, treatment facilities, } \\
\text { and disposal facilities that stage waste must ensure that } \\
\text { the action of staging is included and authorized as part of } \\
\text { their radioactive waste management basis for the affected } \\
\text { facilities, operations, or activities. }\end{array}$ & $\begin{array}{l}\text { As stated in DOE Guide } 435.1-1 \S \text { IV.N.(7), staging } \\
\text { waste in accordance with this requirement allows waste } \\
\text { to be accumulated without being considered storage and } \\
\text { being bound by the associated storage requirements. }\end{array}$ \\
\hline $\begin{array}{l}\text { Staging longer than } 90 \text { days must be justified, the } \\
\text { conditions for such storage met, and these practices } \\
\text { approved by the Field Element Manager as part of the } \\
\text { radioactive waste management basis for the facility. }\end{array}$ & \\
\hline $\begin{array}{l}\text { Compliance with this requirement is demonstrated by a } \\
\text { staging program that limits the temporary storage of } \\
\text { waste to only circumstances allowed in the requirement, } \\
\text { including justifications for any staging that exceeds the } \\
90 \text {-day period, which is documented in the radioactive } \\
\text { waste management basis for the facility. }\end{array}$ & \\
\hline $\begin{array}{l}\text { O. Treatment. Low-level waste treatment to provide } \\
\text { more stable waste forms and to improve the long-term } \\
\text { performance of a low-level waste disposal facility shall } \\
\text { be implemented as necessary to meet the performance } \\
\text { objectives of the disposal facility. }\end{array}$ & NA; TRA-670 is not a LLW treatment facility. \\
\hline $\begin{array}{l}\text { From DOE G } 435.1-1 \text { Chapter IV: Compliance with this } \\
\text { requirement is demonstrated when a treatment facility or } \\
\text { process ensures that treated waste will meet the } \\
\text { minimum waste form requirements of DOE M } 435.1 \text { and } \\
\text { meet additional disposal facility-specific waste } \\
\text { acceptance requirements for additional stability or long- } \\
\text { term performance of facilities that will receive the treated } \\
\text { waste. }\end{array}$ & \\
\hline $\begin{array}{l}\text { P. Disposal. Low-level waste disposal facilities shall } \\
\text { meet the following requirements. }\end{array}$ & NA; TRA-670 is not a LLW disposal facility. \\
\hline $\begin{array}{l}\text { (1) Performance Objectives. Low-level waste disposal } \\
\text { facilities shall be sited, designed, operated, maintained, } \\
\text { and closed so that a reasonable expectation exists that the } \\
\text { following performance objectives will be met for waste } \\
\text { disposed of after September } 26,1988 \text { : }\end{array}$ & See P. above \\
\hline $\begin{array}{l}\text { (a) Dose to representative members of the public shall } \\
\text { not exceed } 25 \text { mrem }(0.25 \mathrm{mSv}) \text { in a year total effective } \\
\text { dose equivalent from all exposure pathways, excluding } \\
\text { the dose from radon and its progeny in air. }\end{array}$ & See P. above \\
\hline
\end{tabular}


Table 7. (continued).

\begin{tabular}{|c|c|}
\hline \multicolumn{2}{|c|}{$\begin{array}{c}\text { Facility Name: TRA-670, ATR Reactor Facility } \\
\text { (includes TRA-605, Warm Waste Treatment Facility, and TRA-1005, Advanced Test Reactor Storage Pad) }\end{array}$} \\
\hline Chapter IV, LLW Requirements & Facility Compliance Information \\
\hline $\begin{array}{l}\text { (b) Dose to representative members of the public via the } \\
\text { air pathway shall not exceed } 10 \mathrm{mrem}(0.10 \mathrm{mSv}) \text { in a } \\
\text { year total effective dose equivalent, excluding the dose } \\
\text { from radon and its progeny. }\end{array}$ & See P. above \\
\hline $\begin{array}{l}\text { (c) Release of radon shall be less than an average flux of } \\
20 \mathrm{pCi} / \mathrm{m}^{2} / \mathrm{s}\left(0.74 \mathrm{~Bq} / \mathrm{m}^{2} / \mathrm{s}\right) \text { at the surface of the disposal } \\
\text { facility. Alternatively, a limit of } 0.5 \mathrm{pCi} / 1(0.0185 \mathrm{~Bq} / \mathrm{l}) \\
\text { of air may be applied at the boundary of the facility. }\end{array}$ & See P. above \\
\hline $\begin{array}{l}\text { (2) Performance Assessment. A site-specific radiological } \\
\text { performance assessment shall be prepared and } \\
\text { maintained for DOE low-level waste disposed of after } \\
\text { September } 26,1988 \text {. The performance assessment shall } \\
\text { include calculations for a } 1,000 \text { year period after closure } \\
\text { of potential doses to representative future members of the } \\
\text { public and potential releases from the facility to provide } \\
\text { a reasonable expectation that the performance objectives } \\
\text { identified in this Chapter are not exceeded as a result of } \\
\text { operation and closure of the facility. }\end{array}$ & See P. above \\
\hline $\begin{array}{l}\text { (a) Analyses performed to demonstrate compliance with } \\
\text { the performance objectives in this Chapter, and to } \\
\text { establish limits on concentrations of radionuclides for } \\
\text { disposal based on the performance measures for } \\
\text { inadvertent intruders in this Chapter shall be based on } \\
\text { reasonable activities in the critical group of exposed } \\
\text { individuals. Unless otherwise specified, the assumption } \\
\text { of average living habits and exposure conditions in } \\
\text { representative critical groups of individuals projected to } \\
\text { receive the highest doses is appropriate. The likelihood } \\
\text { of inadvertent intruder scenarios may be considered in } \\
\text { interpreting the results of the analyses and establishing } \\
\text { radionuclide concentrations, if adequate justification is } \\
\text { provided. }\end{array}$ & See P. above \\
\hline $\begin{array}{l}\text { (b) The point of compliance shall correspond to the point } \\
\text { of highest projected dose or concentration beyond a } 100 \\
\text { meter buffer zone surrounding the disposed waste. A } \\
\text { larger or smaller buffer zone may be used if adequate } \\
\text { justification is provided. }\end{array}$ & See P. above \\
\hline $\begin{array}{l}\text { (c) Performance assessments shall address reasonably } \\
\text { foreseeable natural processes that might disrupt barriers } \\
\text { against release and transport of radioactive materials. }\end{array}$ & See P. above \\
\hline $\begin{array}{l}\text { (d) Performance assessments shall use DOE-approved } \\
\text { dose coefficients (dose conversion factors) for internal } \\
\text { and external exposure of reference adults. }\end{array}$ & See P. above \\
\hline $\begin{array}{l}\text { (e) The performance assessment shall include a } \\
\text { sensitivity/uncertainty analysis. }\end{array}$ & See P. above \\
\hline
\end{tabular}


Table 7. (continued).

\begin{tabular}{|c|c|}
\hline \multicolumn{2}{|c|}{$\begin{array}{c}\text { Facility Name: TRA-670, ATR Reactor Facility } \\
\text { (includes TRA-605, Warm Waste Treatment Facility, and TRA-1005, Advanced Test Reactor Storage Pad) }\end{array}$} \\
\hline Chapter IV, LLW Requirements & Facility Compliance Information \\
\hline $\begin{array}{l}\text { (f) Performance assessments shall include a } \\
\text { demonstration that projected releases of radionuclides to } \\
\text { the environment shall be maintained as low as reasonably } \\
\text { achievable (ALARA). }\end{array}$ & See P. above. \\
\hline $\begin{array}{l}\text { (g) For purposes of establishing limits on radionuclides } \\
\text { that may be disposed of near-surface, the performance } \\
\text { assessment shall include an assessment of impacts to } \\
\text { water resources. }\end{array}$ & See P. above \\
\hline $\begin{array}{l}\text { (h) For purposes of establishing limits on the } \\
\text { concentration of radionuclides that may be disposed of } \\
\text { near-surface, the performance assessment shall include } \\
\text { an assessment of impacts calculated for a hypothetical } \\
\text { person assumed to inadvertently intrude for a temporary } \\
\text { period into the low-level waste disposal facility. For } \\
\text { intruder analyses, institutional controls shall be assumed } \\
\text { to be effective in deterring intrusion for at least } 100 \text { years } \\
\text { following closure. The intruder analyses shall use } \\
\text { performance measures for chronic and acute exposure } \\
\text { scenarios, respectively, of } 100 \text { mrem ( } 1 \mathrm{mSv} \text { ) in a year } \\
\text { and } 500 \text { mrem ( } 5 \text { mSv) total effective dose equivalent } \\
\text { excluding radon in air. }\end{array}$ & See P. above \\
\hline $\begin{array}{l}\text { (3) Composite Analysis. For disposal facilities which } \\
\text { received waste after September } 26,1988 \text {, a site-specific } \\
\text { radiological composite analysis shall be prepared and } \\
\text { maintained that accounts for all sources of radioactive } \\
\text { material that may be left at the DOE site and may } \\
\text { interact with the low- level waste disposal facility, } \\
\text { contributing to the dose projected to a hypothetical } \\
\text { member of the public from the existing or future disposal } \\
\text { facilities. Performance measures shall be consistent with } \\
\text { DOE requirements for protection of the public and } \\
\text { environment and evaluated for a } 1,000 \text { year period } \\
\text { following disposal facility closure. The composite } \\
\text { analysis results shall be used for planning, radiation } \\
\text { protection activities, and future use commitments to } \\
\text { minimize the likelihood that current low- level waste } \\
\text { disposal activities will result in the need for future } \\
\text { corrective or remedial actions to adequately protect the } \\
\text { public and the environment. }\end{array}$ & See P. above \\
\hline $\begin{array}{l}\text { (4) Performance Assessment and Composite Analysis } \\
\text { Maintenance. The performance assessment and } \\
\text { composite analysis shall be maintained to evaluate } \\
\text { changes that could affect the performance, design, and } \\
\text { operating bases for the facility. Performance assessment } \\
\text { and composite analysis maintenance shall include the } \\
\text { conduct of research, field studies, and monitoring needed } \\
\text { to address uncertainties or gaps in existing data. The } \\
\text { performance assessment shall be updated to support the }\end{array}$ & See P. above \\
\hline
\end{tabular}


Table 7. (continued).

\begin{tabular}{|c|c|}
\hline $\begin{array}{r}\text { Facility Name: TRA-67 } \\
\text { (includes TRA-605, Warm Waste Treatment Facility, }\end{array}$ & $\begin{array}{l}\text { 0, ATR Reactor Facility } \\
\text { and TRA-1005, Advanced Test Reactor Storage Pad) }\end{array}$ \\
\hline Chapter IV, LLW Requirements & Facility Compliance Information \\
\hline $\begin{array}{l}\text { final facility closure. Additional iterations of the } \\
\text { performance assessment and composite analysis shall be } \\
\text { conducted as necessary during the post-closure period. }\end{array}$ & \\
\hline $\begin{array}{l}\text { (a) Performance assessments and composite analyses } \\
\text { shall be reviewed and revised when changes in waste } \\
\text { forms or containers, radionuclide inventories, facility } \\
\text { design and operations, closure concepts, or the improved } \\
\text { understanding of the performance of the waste disposal } \\
\text { facility in combination with the features of the site on } \\
\text { which it is located alter the conclusions or the conceptual } \\
\text { model(s) of the existing performance assessment or } \\
\text { composite analysis. }\end{array}$ & See P. above \\
\hline $\begin{array}{l}\text { (b) A determination of the continued adequacy of the } \\
\text { performance assessment and composite analysis shall be } \\
\text { made on an annual basis, and shall consider the results of } \\
\text { data collection and analysis from research, field studies, } \\
\text { and monitoring. }\end{array}$ & See P. above \\
\hline $\begin{array}{l}\text { (c) Annual summaries of low-level waste disposal } \\
\text { operations shall be prepared with respect to the } \\
\text { conclusions and recommendations of the performance } \\
\text { assessment and composite analysis and a determination } \\
\text { of the need to revise the performance assessment or } \\
\text { composite analysis. }\end{array}$ & See P. above \\
\hline $\begin{array}{l}\text { (5) Disposal Authorization. A disposal authorization } \\
\text { statement shall be obtained prior to construction of a new } \\
\text { low-level waste disposal facility. Field Elements with } \\
\text { existing low-level waste disposal facilities shall obtain a } \\
\text { disposal authorization statement in accordance with the } \\
\text { schedule in the Complex-Wide Low-Level Waste } \\
\text { Management Program Plan. The disposal authorization } \\
\text { statement shall be issued based on a review of the } \\
\text { facility's performance assessment, composite analysis, } \\
\text { performance assessment and composite analysis } \\
\text { maintenance, preliminary closure plan, and preliminary } \\
\text { monitoring plan. The disposal authorization statement } \\
\text { shall specify the limits and conditions on construction, } \\
\text { design, operations, and closure of the low-level waste } \\
\text { facility based on these reviews. A disposal authorization } \\
\text { statement is a part of the radioactive waste management } \\
\text { basis for a disposal facility. Failure to obtain a disposal } \\
\text { authorization statement by the implementation date of } \\
\text { this Order shall result in shutdown of the disposal } \\
\text { facility. }\end{array}$ & See P. above \\
\hline $\begin{array}{l}\text { (6) Disposal Facility Operations. The disposal facility } \\
\text { design and operation must be consistent with the disposal } \\
\text { facility closure plan and lead to disposal facility closure } \\
\text { that provides a reasonable expectation that performance } \\
\text { objectives will be met. Low-level waste shall be disposed }\end{array}$ & See P. above \\
\hline
\end{tabular}


Table 7. (continued).

\begin{tabular}{|c|c|}
\hline \multicolumn{2}{|c|}{$\begin{array}{c}\text { Facility Name: TRA-670, ATR Reactor Facility } \\
\text { (includes TRA-605, Warm Waste Treatment Facility, and TRA-1005, Advanced Test Reactor Storage Pad) }\end{array}$} \\
\hline Chapter IV, LLW Requirements & Facility Compliance Information \\
\hline $\begin{array}{l}\text { in such a manner that achieves the performance } \\
\text { objectives stated in this Chapter, consistent with the } \\
\text { disposal facility radiological performance assessment. } \\
\text { Additional requirements include: }\end{array}$ & \\
\hline $\begin{array}{l}\text { (a) Operating procedures shall be developed and } \\
\text { implemented for low-level waste disposal facilities that } \\
\text { protect the public, workers, and the environment; ensure } \\
\text { the security of the facility; minimize subsidence during } \\
\text { and after waste emplacement; achieve long-term stability } \\
\text { and minimize the need for long-term active maintenance; } \\
\text { and meet the requirements of the closure/post-closure } \\
\text { plan. }\end{array}$ & See P. above \\
\hline $\begin{array}{l}\text { (b) Permanent identification markers for disposal } \\
\text { excavations and monitoring wells shall be emplaced. }\end{array}$ & See P. above \\
\hline $\begin{array}{l}\text { (c) Low-level waste placement into disposal units shall } \\
\text { minimize voids between waste containers. Voids within } \\
\text { disposal units shall be filled to the extent practical. } \\
\text { Uncontainerized bulk waste shall also be placed in a } \\
\text { manner that minimizes voids and subsidence. }\end{array}$ & See P. above \\
\hline $\begin{array}{l}\text { (d) Operations are to be conducted so that active waste } \\
\text { disposal operations will not have an adverse effect on } \\
\text { any other disposal units. }\end{array}$ & See P. above. \\
\hline $\begin{array}{l}\text { (e) Operations shall include a process for tracking and } \\
\text { documenting low-level waste placement in the facility by } \\
\text { generator source. }\end{array}$ & See P. above. \\
\hline $\begin{array}{l}\text { (7) Alternate Requirements for Low-Level Waste } \\
\text { Disposal Facility Design and Operation. Requirements } \\
\text { other than those set forth in this Section for the design } \\
\text { and operation of a low-level waste disposal facility may } \\
\text { be approved on a specific basis if a reasonable } \\
\text { expectation is demonstrated that the disposal } \\
\text { performance objectives will be met. }\end{array}$ & See P. above. \\
\hline $\begin{array}{l}\text { Q. Closure. The following requirements are in addition to } \\
\text { those in Chapter I of this Manual. }\end{array}$ & See (1) below. \\
\hline $\begin{array}{l}\text { (1) Disposal Facility Closure Plans. A preliminary } \\
\text { closure plan shall be developed and submitted to } \\
\text { Headquarters for review with the performance } \\
\text { assessment and composite analysis. The closure plan } \\
\text { shall be updated following issuance of the disposal } \\
\text { authorization statement to incorporate conditions } \\
\text { specified in the disposal authorization statement. Closure } \\
\text { plans shall: }\end{array}$ & NA; TRA-670 is not a LLW disposal facility. \\
\hline $\begin{array}{l}\text { (a) Be updated as required during the operational life of } \\
\text { the facility. }\end{array}$ & See (1) above. \\
\hline
\end{tabular}


Table 7. (continued).

\begin{tabular}{|c|c|}
\hline \multicolumn{2}{|c|}{$\begin{array}{l}\text { Facility Name: TRA-670, ATR Reactor Facility } \\
\text { (includes TRA-605, Warm Waste Treatment Facility, and TRA-1005, Advanced Test Reactor Storage Pad) }\end{array}$} \\
\hline Chapter IV, LLW Requirements & Facility Compliance Information \\
\hline $\begin{array}{l}\text { (b) Include a description of how the disposal facility will } \\
\text { be closed to achieve long-term stability and minimize the } \\
\text { need for active maintenance following closure and to } \\
\text { ensure compliance with the requirements of DOE } \\
5400.5 \text {, Radiation Protection of the Public and the } \\
\text { Environment. }\end{array}$ & See (1) above. \\
\hline $\begin{array}{l}\text { (c) Include the total expected inventory of wastes to be } \\
\text { disposed of at the facility over the operational life of the } \\
\text { facility. }\end{array}$ & See (1) above. \\
\hline $\begin{array}{l}\text { (2) Disposal Facility Closure. Closure of a disposal } \\
\text { facility shall occur within a five-year period after it is } \\
\text { filled to capacity, or after the facility is otherwise } \\
\text { determined to be no longer needed. }\end{array}$ & NA; TRA-670 is not a LLW disposal facility. \\
\hline $\begin{array}{l}\text { (a) Prior to facility closure, the final inventory of the } \\
\text { low-level waste disposed in the facility shall be prepared } \\
\text { and incorporated in the performance assessment and } \\
\text { composite analysis which shall be updated to support the } \\
\text { closure of the facility. }\end{array}$ & See (2) above. \\
\hline $\begin{array}{l}\text { (b) A final closure plan shall be prepared based on the } \\
\text { final inventory of waste disposed in the facility, the plan } \\
\text { implemented, and the updated performance assessment } \\
\text { and composite analysis prepared in support of the facility } \\
\text { closure. }\end{array}$ & See (2) above. \\
\hline $\begin{array}{l}\text { (c) Institutional control measures shall be integrated into } \\
\text { land use and stewardship plans and programs, and shall } \\
\text { continue until the facility can be released pursuant to } \\
\text { DOE 5400.5, Radiation Protection of the Public and the } \\
\text { Environment. }\end{array}$ & See (2) above. \\
\hline $\begin{array}{l}\text { (d) The location and use of the facility shall be filed with } \\
\text { the local authorities responsible for land use and zoning. }\end{array}$ & See (2) above. \\
\hline $\begin{array}{l}\text { R. Monitoring. The following requirements are in } \\
\text { addition to those in Chapter I of this Manual [DOE M } \\
\text { 435.1-1 §I.1.E(7)]. }\end{array}$ & $\begin{array}{l}\text { Not a facility-specific requirement. DOE Manual 435.1- } \\
1 \text { §I.1.E(7) applies to field element managers. }\end{array}$ \\
\hline $\begin{array}{l}\text { (1) All Waste Facilities. Parameters that shall be sampled } \\
\text { or monitored, at a minimum, include: temperature, } \\
\text { pressure (for closed systems), radioactivity in ventilation } \\
\text { exhaust and liquid effluent streams, and flammable or } \\
\text { explosive mixtures of gases. Facility monitoring } \\
\text { programs shall include verification that passive and } \\
\text { active control systems have not failed. } \\
\text { From DOE G } 435.1-1 \text { Chapter IV: The minimum } \\
\text { parameters specified in the requirement were selected } \\
\text { based on their potential significance for anticipating and } \\
\text { identifying undesirable conditions at low-level waste } \\
\text { management facilities. Each facility's radioactive waste } \\
\text { management basis should include an evaluation of the }\end{array}$ & $\begin{array}{l}\text { Monitoring requirements at INL radioactive waste } \\
\text { management facilities are tailored for the specific } \\
\text { facility to enable timely indication of developing } \\
\text { problems. Existing radiological control procedures and } \\
\text { assessments are followed/completed to monitor waste } \\
\text { facilities. } \\
\text { LRD-15001 and MCP-139 specify methods and } \\
\text { frequency of radiological control surveys of all } \\
\text { radiological areas. MCP-139 specifies the use of } \\
\text { Form } 441 . \text { A34. This form is referred to as the "routine } \\
\text { sheet" and is to be used by facility radiological control } \\
\text { foremen to list radiological areas that are to be surveyed, } \\
\text { the survey periods, and methods. }\end{array}$ \\
\hline
\end{tabular}


Table 7. (continued).

\begin{tabular}{|c|c|}
\hline \multicolumn{2}{|c|}{$\begin{array}{l}\text { Facility Name: TRA-670, ATR Reactor Facility } \\
\text { (includes TRA-605, Warm Waste Treatment Facility, and TRA-1005, Advanced Test Reactor Storage Pad) }\end{array}$} \\
\hline Chapter IV, LLW Requirements & Facility Compliance Information \\
\hline $\begin{array}{l}\text { applicability and significance of the minimum } \\
\text { parameters. This evaluation also needs to consider } \\
\text { additional parameters to be sampled or monitored to } \\
\text { ensure the protection of the public health, the } \\
\text { environment, and the workers. If a minimum parameter } \\
\text { specified in the requirement is deemed to be not } \\
\text { applicable in any way to the active operation of that } \\
\text { facility, then that justification should be included in the } \\
\text { radioactive waste management basis and when approved } \\
\text { constitutes an exemption to the manual. }\end{array}$ & \\
\hline $\begin{array}{l}\text { Verification activities are part of the radioactive waste } \\
\text { management basis as a condition for operation and } \\
\text { documented appropriately. }\end{array}$ & \\
\hline $\begin{array}{l}\text { Compliance with this requirement is demonstrated if } \\
\text { monitoring or sampling for the stated parameters is } \\
\text { performed for all facilities with a precision, accuracy, } \\
\text { and frequency consistent with timely identification of } \\
\text { developing problems and a justification exists in the } \\
\text { approved radioactive waste management basis for those } \\
\text { specified parameters which are not monitored or } \\
\text { sampled. }\end{array}$ & \\
\hline $\begin{array}{l}\text { (2) Liquid Waste Storage Facilities. For facilities storing } \\
\text { liquid low-level waste, the following shall also be } \\
\text { monitored: liquid level and/or waste volume, and } \\
\text { significant waste chemistry parameters. }\end{array}$ & NA; TRA-670 does not store liquid LLW. \\
\hline $\begin{array}{l}\text { (3) Disposal Facilities. A preliminary monitoring plan for } \\
\text { a low-level waste disposal facility shall be prepared and } \\
\text { submitted to Headquarters for review with the } \\
\text { performance assessment and composite analysis. The } \\
\text { monitoring plan shall be updated within one year } \\
\text { following issuance of the disposal authorization } \\
\text { statement to incorporate and implement conditions } \\
\text { specified in the disposal authorization statement. }\end{array}$ & NA; TRA-670 is not a LLW disposal facility. \\
\hline $\begin{array}{l}\text { (a) The site-specific performance assessment and } \\
\text { composite analysis shall be used to determine the media, } \\
\text { locations, radionuclides, and other substances to be } \\
\text { monitored. }\end{array}$ & See (3) above. \\
\hline $\begin{array}{l}\text { (b) The environmental monitoring program shall be } \\
\text { designed to include measuring and evaluating releases, } \\
\text { migration of radionuclides, disposal unit subsidence, and } \\
\text { changes in disposal facility and disposal site parameters } \\
\text { which may affect long-term performance. }\end{array}$ & See (3) above. \\
\hline $\begin{array}{l}\text { (c) The environmental monitoring programs shall be } \\
\text { capable of detecting changing trends in performance to } \\
\text { allow application of any necessary corrective action prior } \\
\text { to exceeding the performance objectives in this Chapter. }\end{array}$ & See (3) above. \\
\hline
\end{tabular}




\subsection{TRA-678, Radiation Measurements Laboratory}

1. Description: TRA-678, Radiation Measurements Laboratory, houses the ATR gamma-ray spectroscopy capabilities, which include a radiation measurement area; one tritium analysis and sample preparation area; four-channel counting equipment, sample receiving, and storage; field radiography photo development; two iron rooms; a radiological control office; and an instrument laboratory. The samples submitted for analysis encompass a wide range of support for programs within ATR and INL as a whole.

2. Hazard category: LTHC3 (radiological)

3. Radioactive waste management activities at this facility: LLW and mixed LLW from routine laboratory operations are generated and staged at this facility. TSCA-regulated LLW may be generated and staged at this facility.

\section{RWMB documents/programs:}

a) Safety basis/hazard analysis:

- ECAR-484, "Hazard Categorization Document for the New Radiation Measurement Laboratory (TRA-678) at the ATR Complex"

b) Laboratory-wide:

- LI-435, "Waste Management Routine Field Activities"

- LWP-13840, "Management of Issues, Observations, and Noteworthy Practices"

- LWP-14002, "Timeout and Stop Work Authority"

- LWP-15011, "Radioactive Material Areas and Radioactive Storage Areas"

- MCP-17000, "Waste Generator Services Waste Management"

$-\quad$

- MCP-17410, "Management of Waste Storage Areas"

- MCP-17500, "Waste Generator Services Certification of Waste Shipments to the Nevada Test Site"

- PDD-17000, "Waste Management Program"

- PLN-114, "INL Emergency Plan/RCRA Contingency Plan"

c) Facility-specific:

- ACLP-10.10, "RTC Radioanalytical Sample Management."

Table 8 presents the facility compliance information for Chapter IV, "Low-level Waste Requirements."

Table 8. TRA-678, Radiation Measurements Laboratory, DOE Manual 435.1-1 low-level waste requirements and facility compliance information.

\begin{tabular}{|l|l|}
\hline \multicolumn{2}{|c|}{ Facility Name: TRA-678, Radiation Measurements Laboratory } \\
\hline \multicolumn{1}{|c|}{ Chapter IV, LLW Requirements } & \multicolumn{1}{c|}{ Facility Compliance Information } \\
\hline $\begin{array}{l}\text { A. Definition of Low-Level Waste. Low-level radioactive } \\
\text { waste is radioactive waste that is not high-level radioactive }\end{array}$ & $\begin{array}{l}\text { This requirement provides the criteria for determining } \\
\text { which DOE radioactive waste is to be managed as }\end{array}$ \\
waste, spent nuclear fuel, transuranic waste, byproduct & LLW in accordance with DOE Manual 435.1-1, \\
material (as defined in section 11e.(2) of the Atomic Energy & Chapter IV. \\
material. & $\begin{array}{l}\text { Radioactive waste managed at this facility under the } \\
\text { requirements of this chapter is not managed under the } \\
\text { requirements of DOE Manual 435.1-1, Chapter II or }\end{array}$ \\
\hline
\end{tabular}


Table 8. (continued).

\begin{tabular}{|c|c|}
\hline \multicolumn{2}{|c|}{ Facility Name: TRA-678, Radiation Measurements Laboratory } \\
\hline Chapter IV, LLW Requirements & Facility Compliance Information \\
\hline & Chapter III. \\
\hline $\begin{array}{l}\text { B. Management of Specific Wastes. The following provide } \\
\text { for management of specific wastes as low-level waste in } \\
\text { accordance with the requirements in this Chapter: }\end{array}$ & See (1), (2), (3), and (4) below. \\
\hline $\begin{array}{l}\text { (1) Mixed Low-Level Waste. Low-level waste determined } \\
\text { to contain both source, special nuclear, or byproduct } \\
\text { material subject to the Atomic Energy Act of 1954, as } \\
\text { amended, and a hazardous component subject to the } \\
\text { Resource Conservation and Recovery Act (RCRA), as } \\
\text { amended, shall be managed in accordance with the } \\
\text { requirements of RCRA and DOE O } 435.1 \text {, Radioactive } \\
\text { Waste Management, and this Manual. }\end{array}$ & $\begin{array}{l}\text { This facility manages mixed LLW in SAAs. } \\
\text { Management of SAAs is addressed in MCP-17410, } \\
\text { and overall management of mixed waste is addressed } \\
\text { in MCP-17000. }\end{array}$ \\
\hline $\begin{array}{l}\text { (2) TSCA-Regulated Waste. Low-level waste containing } \\
\text { polychlorinated biphenyls, asbestos, or other such regulated } \\
\text { toxic components shall be managed in accordance with } \\
\text { requirements derived from the Toxic Substances Control } \\
\text { Act, as amended, DOE O } 435.1 \text {, Radioactive Waste } \\
\text { Management, and this Manual. }\end{array}$ & $\begin{array}{l}\text { This facility may manage TSCA-regulated waste. } \\
\text { Such waste would be managed in accordance with } \\
\text { MCP-17410 and MCP-17000. }\end{array}$ \\
\hline $\begin{array}{l}\text { (3) Accelerator-Produced Waste. Radioactive waste } \\
\text { produced as a result of operations of DOE accelerators is } \\
\text { low-level waste and shall be managed in accordance with } \\
\text { DOE O } 435.1 \text {, Radioactive Waste Management, and this } \\
\text { Manual, and all applicable Federal or State requirements. }\end{array}$ & $\begin{array}{l}\text { NA; this facility does not manage accelerator- } \\
\text { produced waste. }\end{array}$ \\
\hline $\begin{array}{l}\text { (4) } 11 \text { e.(2) and Naturally Occurring Radioactive Material. } \\
\text { Small quantities of } 11 \text { e.(2) byproduct material and naturally } \\
\text { occurring radioactive material may be managed as low-level } \\
\text { waste provided they can be managed to meet the } \\
\text { requirements for low-level waste disposal in Section IV.P of } \\
\text { this Manual. }\end{array}$ & $\begin{array}{l}\mathrm{NA} \text {; this facility does not manage naturally occurring } \\
\text { radioactive material. }\end{array}$ \\
\hline $\begin{array}{l}\text { C. Complex-Wide Low-Level Waste Management Program. } \\
\text { A complex-wide program and plan shall be developed as } \\
\text { described under Responsibilities, 2.B and 2.D, in Chapter I } \\
\text { of this Manual. }\end{array}$ & $\begin{array}{l}\text { Not a facility-specific requirement. DOE Manual } \\
435.1-1 \S \text { I.2.B and §I.2.D apply to the Assistant } \\
\text { Secretary for Environmental Management and the } \\
\text { Deputy Assistant Secretary for Waste Management, } \\
\text { respectively. }\end{array}$ \\
\hline $\begin{array}{l}\text { D. Radioactive Waste Management Basis. Low-level waste } \\
\text { facilities, operations, and activities shall have a radioactive } \\
\text { waste management basis consisting of physical and } \\
\text { administrative controls to ensure the protection of workers, } \\
\text { the public, and the environment. The following specific } \\
\text { waste management controls shall be part of the radioactive } \\
\text { waste management basis: }\end{array}$ & $\begin{array}{l}\text { The RWMB provides the regulatory framework for } \\
\text { management of radioactive waste at INL. It } \\
\text { specifically identifies facility management and } \\
\text { implementing documents for the generation, storage, } \\
\text { treatment, and disposal of radiological waste. } \\
\text { ECAR-484 establishes this facility as a LTHC3 } \\
\text { (radiological) facility. }\end{array}$ \\
\hline $\begin{array}{l}\text { (1) Generators. The waste certification program. } \\
\text { From DOE G } 435.1-1 \text { Chapter IV: } \\
\text { For a facility that generates low-level waste, the radioactive } \\
\text { waste management basis is to include the program for }\end{array}$ & $\begin{array}{l}\text { See J. below for waste certification program } \\
\text { requirements. }\end{array}$ \\
\hline
\end{tabular}


Table 8. (continued).

\begin{tabular}{|c|c|}
\hline \multicolumn{2}{|c|}{ Facility Name: TRA-678, Radiation Measurements Laboratory } \\
\hline Chapter IV, LLW Requirements & Facility Compliance Information \\
\hline $\begin{array}{l}\text { certifying that waste meets the waste acceptance } \\
\text { requirements of the facility(ies) to which the waste will be } \\
\text { sent. }\end{array}$ & \\
\hline $\begin{array}{l}\text { (2) Treatment Facilities. certification program. The waste } \\
\text { acceptance requirements and the waste }[\mathrm{sic}]\end{array}$ & $\begin{array}{l}\text { NA; this facility is not a radioactive waste treatment } \\
\text { facility. }\end{array}$ \\
\hline From DOE G 435.1-1 Chapter IV: & \\
\hline $\begin{array}{l}\text { Facilities that store or treat low-level waste are to have } \\
\text { approved waste acceptance requirements (see DOE M } \\
435.1-1 \text {, Section IV.G) prior to the issuance of a radioactive } \\
\text { waste management basis. }\end{array}$ & \\
\hline $\begin{array}{l}\text { A facility that stores or treats waste also is generally } \\
\text { expected to have a waste certification program. Waste from } \\
\text { these facilities will have to be certified as meeting the waste } \\
\text { acceptance requirements of the facility to which it will be } \\
\text { transferred, and the facilities have the potential for } \\
\text { generating radioactive waste (e.g., secondary processing } \\
\text { streams from treatment, monitoring and sampling, } \\
\text { radioactive release cleanup). Consequently, storage and } \\
\text { treatment facilities should also have an approved waste } \\
\text { certification program as part of their radioactive waste } \\
\text { management basis. }\end{array}$ & \\
\hline $\begin{array}{l}\text { As part of the radioactive waste management basis, site } \\
\text { personnel needs to implement a system or process for } \\
\text { tracking the waste inventory at a storage, treatment, or } \\
\text { disposal facility. }\end{array}$ & \\
\hline $\begin{array}{l}\text { (3) Storage Facilities. The waste acceptance requirements } \\
\text { and the waste certification program. }\end{array}$ & $\begin{array}{l}\text { NA; this facility is not a radioactive waste storage } \\
\text { facility. }\end{array}$ \\
\hline From DOE G 435.1-1 Chapter IV: & \\
\hline $\begin{array}{l}\text { Facilities that store or treat low-level waste are to have } \\
\text { approved waste acceptance requirements (see DOE M } \\
435.1-1 \text {, Section IV.G) prior to the issuance of a radioactive } \\
\text { waste management basis. }\end{array}$ & \\
\hline $\begin{array}{l}\text { A facility that stores or treats waste also is generally } \\
\text { expected to have a waste certification program. Waste from } \\
\text { these facilities will have to be certified as meeting the waste } \\
\text { acceptance requirements of the facility to which it will be } \\
\text { transferred, and the facilities have the potential for } \\
\text { generating radioactive waste (e.g., secondary processing } \\
\text { streams from treatment, monitoring and sampling, } \\
\text { radioactive release cleanup). Consequently, storage and } \\
\text { treatment facilities should also have an approved waste } \\
\text { certification program as part of their radioactive waste } \\
\text { management basis. }\end{array}$ & \\
\hline $\begin{array}{l}\text { As part of the radioactive waste management basis, site } \\
\text { personnel needs to implement a system or process for } \\
\text { tracking the waste inventory at a storage, treatment, or }\end{array}$ & \\
\hline
\end{tabular}


Table 8. (continued).

\begin{tabular}{|c|c|}
\hline \multicolumn{2}{|c|}{ Facility Name: TRA-678, Radiation Measurements Laboratory } \\
\hline Chapter IV, LLW Requirements & Facility Compliance Information \\
\hline disposal facility. & \\
\hline $\begin{array}{l}\text { (4) Disposal Facilities. The performance assessment, } \\
\text { composite analysis, disposal authorization statement, } \\
\text { closure plan, waste acceptance requirements, and } \\
\text { monitoring plan. }\end{array}$ & $\begin{array}{l}\text { NA; this facility is not a radioactive waste disposal } \\
\text { facility. }\end{array}$ \\
\hline $\begin{array}{l}\text { E. Contingency Actions. The following requirements are in } \\
\text { addition to those in Chapter I of this Manual [DOE M } \\
\text { 435.1-1 §I.1.E(5)]. }\end{array}$ & $\begin{array}{l}\text { Not a facility-specific requirement. DOE Manual } \\
435.1-1 \text { §I.1.E(5) addresses the sitewide emergency } \\
\text { management system. The INL plan is provided in } \\
\text { PLN-114. }\end{array}$ \\
\hline $\begin{array}{l}\text { (1) Contingency Storage. For off-normal or emergency } \\
\text { situations involving high activity or high hazard liquid low- } \\
\text { level waste storage or treatment, spare capacity with } \\
\text { adequate capabilities shall be maintained to receive the } \\
\text { largest volume of liquid contained in any one storage tank } \\
\text { or treatment facility. Tanks or other facilities that are } \\
\text { designated low-level waste contingency storage shall be } \\
\text { maintained in an operational condition when waste is } \\
\text { present and shall meet the requirements of DOE O } 435.1 \text {, } \\
\text { Radioactive Waste Management, and this Manual. } \\
\text { From DOE G } 435.1-1 \text { Chapter IV: } \\
\text { Compliance with these requirements is demonstrated if } \\
\text { adequate spare capacity and transfer equipment exists for } \\
\text { emergency transfers of all high activity and high hazard } \\
\text { liquid low-level waste. In addition, the capability to perform } \\
\text { emergency transfers is demonstrated by having waste } \\
\text { transfer routings identified, operational procedures to direct } \\
\text { transfers, staff trained to the procedures, and records } \\
\text { showing that the spare capacity and transfer capability are } \\
\text { kept in operating condition. }\end{array}$ & NA; this facility does not store liquid LLW in tanks. \\
\hline $\begin{array}{l}\text { (2) Transfer Equipment. Pipelines and auxiliary facilities } \\
\text { necessary for the transfer of high activity or high hazard } \\
\text { liquid low-level waste to contingency storage shall be } \\
\text { maintained in an operational condition when waste is } \\
\text { present and shall meet the requirements of DOE O 435.1, } \\
\text { Radioactive Waste Management, and this Manual. } \\
\text { From DOE G } 435.1-1 \text { Chapter IV: } \\
\text { Compliance with these requirements is demonstrated if } \\
\text { adequate spare capacity and transfer equipment exists for } \\
\text { emergency transfers of all high activity and high hazard } \\
\text { liquid low-level waste. In addition, the capability to perform } \\
\text { emergency transfers is demonstrated by having waste } \\
\text { transfer routings identified, operational procedures to direct } \\
\text { transfers, staff trained to the procedures, and records } \\
\text { showing that the spare capacity and transfer capability are } \\
\text { kept in operating condition. }\end{array}$ & NA; this facility does not store liquid LLW in tanks. \\
\hline
\end{tabular}


Table 8. (continued).

\begin{tabular}{|c|c|}
\hline \multicolumn{2}{|c|}{ Facility Name: TRA-678, Radiation Measurements Laboratory } \\
\hline Chapter IV, LLW Requirements & Facility Compliance Information \\
\hline $\begin{array}{l}\text { F. Corrective Actions. I of this Manual. The following } \\
\text { requirements are in addition to those in Chapter [sic] } \\
\text { From DOE G 435.1-1 Chapter IV: } \\
\text { Compliance with DOE M 435.1-1 §I.2.G.(1) is } \\
\text { demonstrated by records showing what corrective actions } \\
\text { were taken to remedy situations in the radioactive waste } \\
\text { management system. } \\
\text { Compliance with DOE M 435.1-1 §I.2.G.(2) is } \\
\text { demonstrated by having the necessary procedures, } \\
\text { mechanisms, and training in place to effect shutdown or } \\
\text { curtailment of activities which pose an imminent danger or } \\
\text { other serious hazard to workers or the public, or are not } \\
\text { protective of the environment. }\end{array}$ & $\begin{array}{l}\text { The INL-wide procedure addressing problem } \\
\text { identification as required by DOE Manual 435.1-1 } \\
\text { §I.2.G.(1) is, which implements the laboratory's } \\
\text { corrective action system. } \\
\text { The INL-wide procedure addressing shutdown or } \\
\text { curtailment of activities as required by DOE } \\
\text { Manual 435.1-1 §I.2.G.(2) is LWP-14002. }\end{array}$ \\
\hline $\begin{array}{l}\text { (1) Order Compliance. Corrective actions shall be } \\
\text { implemented whenever necessary to ensure the } \\
\text { requirements of DOE O } 435.1 \text {, Radioactive Waste } \\
\text { Management, and this Manual are met. } \\
\text { From DOE G 435.1-1 Chapter IV: } \\
\text { If a facility or activity can be allowed to operate while a } \\
\text { noncompliant or hazardous condition exists, the allowance } \\
\text { and any associated limitations must be defined as part of the } \\
\text { facility or activity's radioactive waste management basis, } \\
\text { identified as a configuration controlled item in a } \\
\text { configuration management plan or included in a revision or } \\
\text { modification to an operating procedure or similar controlled } \\
\text { documentation. } \\
\text { Compliance with this requirement is demonstrated if a } \\
\text { corrective action system addresses noncompliant or } \\
\text { hazardous situations involving low-level waste management } \\
\text { facilities in a systematic fashion, and allows identification of } \\
\text { problems by all personnel. }\end{array}$ & See F. above. \\
\hline $\begin{array}{l}\text { (2) Operations Curtailment. Operations shall be curtailed or } \\
\text { facilities shut down for failure to establish, maintain, or } \\
\text { operate consistent with an approved radioactive waste } \\
\text { management basis. } \\
\text { From DOE G 435.1-1 Chapter IV: } \\
\text { Compliance with this requirement is demonstrated with a } \\
\text { documented system of routine assessments to determine } \\
\text { whether waste management activities and facilities are } \\
\text { operating in accordance with an approved radioactive waste } \\
\text { management basis that provides for graded limitations that } \\
\text { can be placed on activities and operations that do not have, } \\
\text { or are operating outside of, an approved radioactive waste } \\
\text { management basis, including shutdown of the facility. }\end{array}$ & $\begin{array}{l}\text { The approved RWMB establishes the current } \\
\text { compliance status at each radioactive waste } \\
\text { management facility. Facility assessments are } \\
\text { scheduled to ensure waste management activities are } \\
\text { conducted in accordance with the approved RWMB. }\end{array}$ \\
\hline G. Waste Acceptance. The following requirements are in & Not a facility-specific requirement. DOE Manual \\
\hline
\end{tabular}


Table 8. (continued).

\begin{tabular}{|c|c|}
\hline \multicolumn{2}{|c|}{ Facility Name: TRA-678, Radiation Measurements Laboratory } \\
\hline Chapter IV, LLW Requirements & Facility Compliance Information \\
\hline $\begin{array}{l}\text { addition to those in Chapter I of this Manual [DOE M } \\
435.1-1 \S I .2 . F(6)] \text {. }\end{array}$ & 435.1-1 §I.2.F(6) applies to field element managers. \\
\hline $\begin{array}{l}\text { (1) Technical and Administrative. Waste acceptance } \\
\text { requirements for all low-level waste storage, treatment, or } \\
\text { disposal facilities, operations, and activities shall specify, at } \\
\text { a minimum, the following: }\end{array}$ & $\begin{array}{l}\text { NA; TRA-678 does not receive LLW for storage, } \\
\text { treatment, or disposal; therefore, it is not subject to } \\
\text { this requirement. }\end{array}$ \\
\hline From DOE G 435.1-1 Chapter IV: & \\
\hline $\begin{array}{l}\text { Compliance with these waste acceptance requirements is } \\
\text { demonstrated if they are documented, contain clear and } \\
\text { precise criteria specifying the radionuclide limits in the form } \\
\text { of contents or concentrations that can be accepted, the } \\
\text { limitations and prohibitions on waste forms and packages } \\
\text { that can be received, and the limits, prohibitions, or } \\
\text { instructions concerning any other technical information so } \\
\text { that the waste is compatible with the safety basis of the } \\
\text { facility, and which will result in acceptable waste at } \\
\text { subsequent steps in managing the low-level waste.) }\end{array}$ & \\
\hline $\begin{array}{l}\text { (a) Allowable activities and/or concentrations of specific } \\
\text { radionuclides. }\end{array}$ & See (1) above. \\
\hline $\begin{array}{l}\text { (b) Acceptable waste form and/or container requirements } \\
\text { that ensure the chemical and physical stability of waste } \\
\text { under conditions that might be encountered during } \\
\text { transportation, storage, treatment, or disposal. }\end{array}$ & See (1) above. \\
\hline $\begin{array}{l}\text { (c) Restrictions or prohibitions on waste, materials, or } \\
\text { containers that may adversely affect waste handlers or } \\
\text { compromise facility or waste container performance. }\end{array}$ & See (1) above. \\
\hline $\begin{array}{l}\text { (d) The following are additional waste acceptance } \\
\text { requirements that shall be specified in low-level waste } \\
\text { disposal facility waste acceptance requirements: }\end{array}$ & NA; this facility is not a LLW disposal facility. \\
\hline $\begin{array}{l}1 \text { Low-level waste must contribute to and not detract from } \\
\text { achieving long-term stability of the facility, minimizing the } \\
\text { need for long-term active maintenance, minimizing } \\
\text { subsidence, and minimizing contact of water with waste. } \\
\text { Void spaces within the waste and, if containers are used, } \\
\text { between the waste and its container shall be reduced to the } \\
\text { extent practical. }\end{array}$ & See (d) above. \\
\hline $\begin{array}{l}2 \text { Liquid low-level waste or low-level waste containing free } \\
\text { liquid must be converted into a form that contains as little } \\
\text { freestanding liquid as is reasonably achievable, but in no } \\
\text { case shall the liquid exceed } 1 \text { percent of the waste volume } \\
\text { when the low-level waste is in a disposal container, or } 0.5 \\
\text { percent of the waste volume after it is processed to a stable } \\
\text { form. }\end{array}$ & See (d) above. \\
\hline
\end{tabular}


Table 8. (continued).

\begin{tabular}{|c|c|}
\hline \multicolumn{2}{|c|}{ Facility Name: TRA-678, Radiation Measurements Laboratory } \\
\hline Chapter IV, LLW Requirements & Facility Compliance Information \\
\hline $\begin{array}{l}3 \text { Low-level waste must not be readily capable of detonation } \\
\text { or of explosive decomposition or reaction at anticipated } \\
\text { pressures and temperatures, or of explosive reaction with } \\
\text { water. Pyrophoric materials contained in waste shall be } \\
\text { treated, prepared, and packaged to be nonflammable. }\end{array}$ & See (d) above. \\
\hline $\begin{array}{l}4 \text { Low-level waste must not contain, or be capable of } \\
\text { generating by radiolysis or biodegradation, quantities of } \\
\text { toxic gases, vapors, or fumes harmful to the public or } \\
\text { workers or disposal facility personnel, or harmful to the } \\
\text { long-term structural stability of the disposal site. }\end{array}$ & See (d) above. \\
\hline $\begin{array}{l}5 \text { Low-level waste in a gaseous form must be packaged such } \\
\text { that the pressure does not exceed } 1.5 \text { atmospheres absolute } \\
\text { at } 20 \mathrm{C} \text {. [ } \mathrm{sic}]\end{array}$ & See (d) above. \\
\hline $\begin{array}{l}\text { (e) The basis, procedures, and levels of authority required } \\
\text { for granting exceptions to the waste acceptance } \\
\text { requirements, which shall be contained in each facility's } \\
\text { waste acceptance documentation. Each exception request } \\
\text { shall be documented, including its disposition as approved } \\
\text { or not approved. } \\
\text { From DOE G 435.1-1 Chapter IV: } \\
\text { Waste acceptance requirements are acceptable if they are } \\
\text { documented and contain a clear description of the procedure } \\
\text { and bases for obtaining an exception or deviation to the } \\
\text { acceptance criteria for low-level waste to be received at the } \\
\text { facility. }\end{array}$ & NA; this facility does not accept waste from others. \\
\hline $\begin{array}{l}\text { (2) Evaluation and Acceptance. The receiving facility shall } \\
\text { evaluate waste for acceptance, including confirmation that } \\
\text { the technical and administrative requirements have been } \\
\text { met. A process for the disposition of non-conforming wastes } \\
\text { shall be established. } \\
\text { From DOE G 435.1-1 Chapter IV: } \\
\text { Compliance with the waste acceptance requirements for a } \\
\text { low-level waste management facility is demonstrated if } \\
\text { they include a process for evaluation and acceptance of } \\
\text { incoming waste to ensure the acceptance criteria of the } \\
\text { facility receiving the waste are met that includes one of or a } \\
\text { combination of: (1) testing, sampling, and analysis of } \\
\text { representative samples of waste upon receipt; (2) testing, } \\
\text { sampling, and analysis of split samples of waste taken at the } \\
\text { generator site; (3) evaluation of testing, sampling, and } \\
\text { analysis of data provided by the generator, or (4) audits, } \\
\text { reviews, surveillance, or observations of generator waste } \\
\text { certification programs and characterization activities. } \\
\text { Additionally, acceptable waste acceptance requirements for } \\
\text { a storage, treatment or disposal facility will have } \\
\text { documented procedures and actions to be taken if a waste } \\
\text { that does not conform to the waste acceptance criteria is } \\
\text { received at the facility. }\end{array}$ & $\begin{array}{l}\text { NA; this facility does not store, treat, or dispose of } \\
\text { LLW. }\end{array}$ \\
\hline
\end{tabular}


Table 8. (continued).

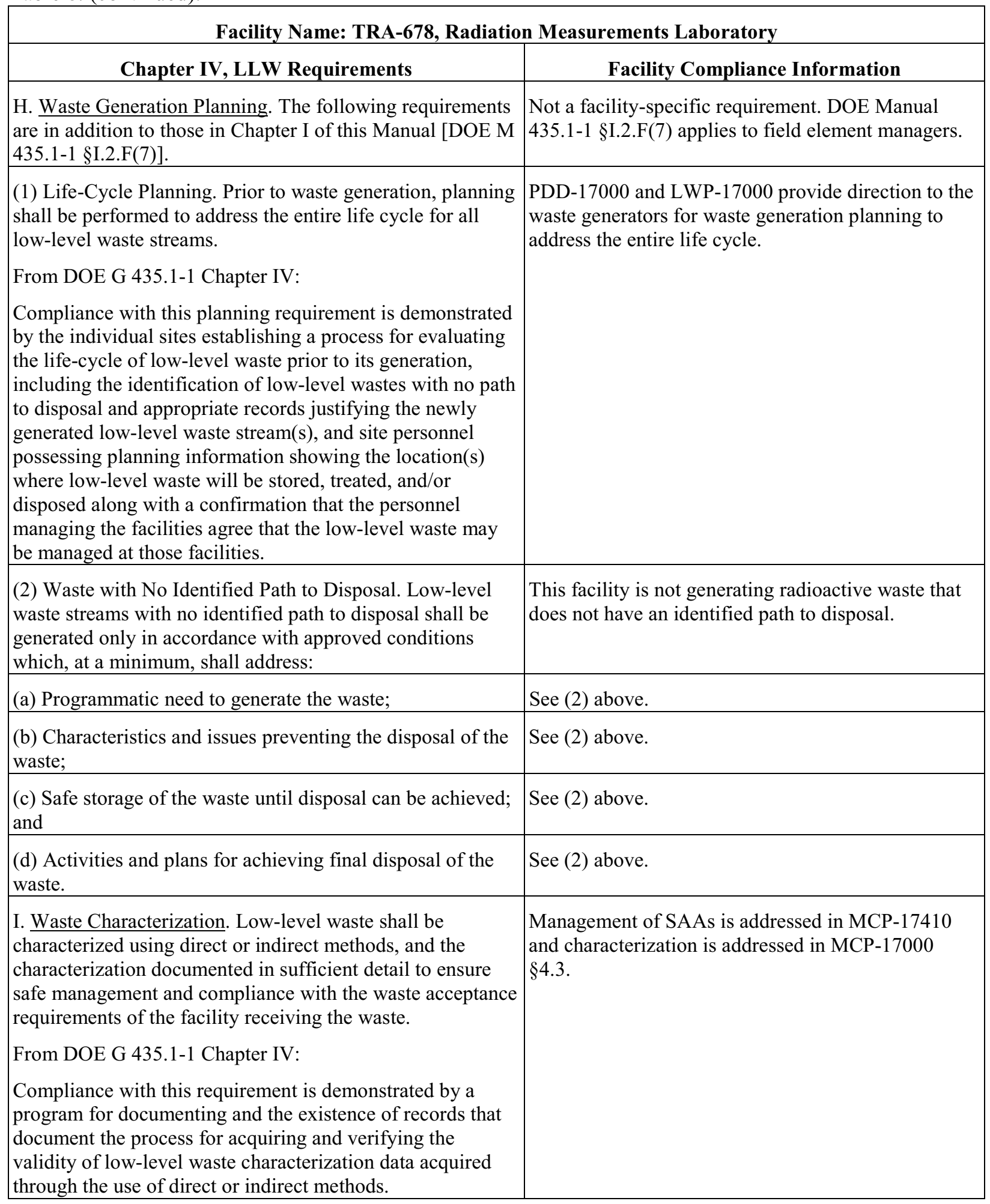


Table 8. (continued).

Facility Name: TRA-678, Radiation Measurements Laboratory

\begin{tabular}{l} 
Facility Name: TRA-678, Radiation \\
\hline \multicolumn{1}{|c}{ Chapter IV, LLW Requirements } \\
\hline (1) Data Quality Objectives. The data quality objectives \\
process, or a comparable process, shall be used for \\
identifying characterization parameters and acceptable \\
uncertainty in characterization data. \\
From DOE G 435.1-1 Chapter IV: \\
Compliance with this requirement is demonstrated by the \\
documented use of a data quality objectives or a comparable \\
process for determining the type, quantity, and quality of \\
characterization data needed to safely manage low-level \\
waste.
\end{tabular}

(2) Minimum Waste Characterization. Characterization data shall, at a minimum, include the following information relevant to the management of the waste:

From DOE G 435.1-1 Chapter IV:

Compliance with this requirement is demonstrated by the existence of a program or procedure for determining and records that document characterization of low-level waste consistent with the minimum characterization data requirements.)

(a) Physical and chemical characteristics;

(b) Volume, including the waste and any stabilization or absorbent media;

(c) Weight of the container and contents;

(d) Identities, activities, and concentrations of major radionuclides;

(e) Characterization date;

(f) Generating source; and

(g) Any other information which may be needed to prepare and maintain the disposal facility performance assessment, or demonstrate compliance with applicable performance

\section{Facility Compliance Information}

Radioactive waste management facilities characterize waste in accordance with the requirements of the receiving storage, treatment, or disposal facility. The documented use of a data quality objectives process, or comparable process, was not identified for this facility.

ACLP-10.10 specifies methods for labeling, logging, and storing samples at this facility. NOTE: Although this procedure is the one by which characterization data is currently managed, it was written when the analyses were conducted in multiple facilities and therefore requires revision to reflect these activities as only being conducted in TRA-678.

Management of SAAs is addressed in MCP-17410

and characterization is addressed in MCP-17000 $\S 4.3$.

MCP-17000, including $\S \S 4.2,4.3$, and 4.4, address waste characterization. Information on physical and chemical characteristics is generally required.

MCP-17000 $\$ 4.2$ requires generator information on the volume of waste expected to be generated.

Information on absorbent media is required in $\S \S 4.5$ and 4.7 .

MCP-17000 $\$ 4.7 .8$ requires weight information if waste from different generators is being consolidated into one container. This is not the case in this facility.

MCP-17000, Rev. 1, including $\S \S 4.2,4.3,4.4$, address waste characterization. Information on major radionuclides is generally required.

MCP-17000 generally requires the date that a form is signed or an entry is made into a log or IWTS be captured. The date that the characterization is performed is not explicitly required to be captured.

Regarding the routine solid LLW streams generated subsequent to operations, MCP-17000, including $\S \S 4.2,4.3$, and 4.4 , addresses waste characterization. Information on the generating source is generally required.

MCP-17000 does not specifically describe information needed to address disposal facility performance assessment and performance objectives. 
Table 8. (continued).

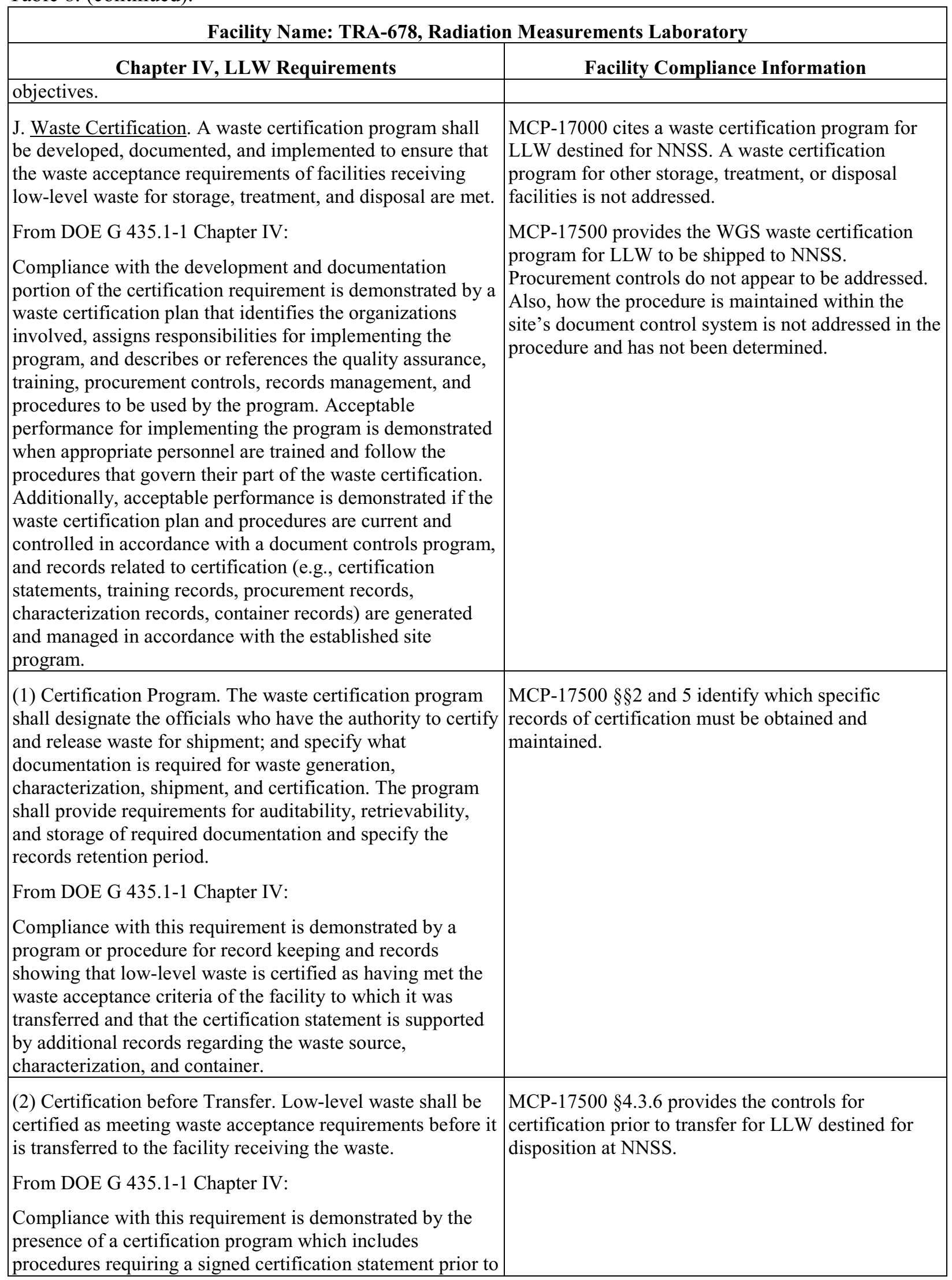


Table 8. (continued).

Facility Name: TRA-678, Radiation Measurements Laboratory

\begin{tabular}{l} 
Chapter IV, LLW Requirements \\
\hline $\begin{array}{l}\text { the release of waste for transfer, and by dated records } \\
\text { showing that waste was certified before being transferred. }\end{array}$ \\
(3) Maintaining Certification. Low-level waste that has been \\
certified as meeting the waste acceptance requirements for \\
transfer to a storage, treatment, or disposal facility shall be \\
managed in a manner that maintains its certification status. \\
From DOE G 435.1-1 Chapter IV: \\
Compliance with this requirement is demonstrated by a \\
program or procedure reflecting this requirement is present \\
and site personnel are able to show that the storage of low- \\
level waste containers is in a facility or manner where the \\
containers would not be damaged by normal weather events, \\
and cannot be accessed by unauthorized personnel. Further, \\
each container can be traced to its certification and the \\
information supporting that certification.
\end{tabular}

K. Waste Transfer. A documented process shall be established and implemented for transferring responsibility for management of low-level waste and for ensuring availability of relevant data. The following requirements are in addition to those in Chapter I of this Manual.

From DOE G 435.1-1 Chapter IV:

Compliance with this requirement is demonstrated if facilities have procedures for the receipt of waste and the transfer of waste, as appropriate, which address the acquisition of waste and container data and the transfer of ownership, respectively. Further evidence of acceptable performance is facility records showing that data on the waste containers is available and accurate, and that documented transfer of responsibility occurs.

(1) Authorization. Low-level waste shall not be transferred to a storage, treatment, or disposal facility until personnel responsible for the facility receiving the waste authorize the transfer.

From DOE G 435.1-1 Chapter IV:

Compliance with this requirement is demonstrated by sites having procedures that require a confirmation of authorization before releasing waste for transfer, and records showing that transfers are made in accordance with written authorizations.

(2) Data. Waste characterization data, container information, See K. above. and generation, storage, treatment, and transportation information for low-level waste shall be transferred with or be traceable to the waste.

Compliance with this requirement is demonstrated if there are procedures requiring that characterization and container data be provided and maintained for each low-level waste 
Table 8. (continued).

Facility Name: TRA-678, Radiation Measurements Laboratory

\begin{tabular}{l} 
Chapter IV, LLW Requirements \\
\hline $\begin{array}{l}\text { transfer and documented records of transfers show that the } \\
\text { information is being provided. }\end{array}$ \\
$\begin{array}{l}\text { L. Packaging and Transportation. The following } \\
\text { requirements are in addition to those in Chapter I of this } \\
\text { Manual [DOE M 435.1-1 §I.1.E(11)]. }\end{array}$ \\
\hline
\end{tabular}

(1) Packaging. If containers are used:

From DOE G 435.1-1 Chapter IV:

Compliance with the packaging requirement is demonstrated by: (1) procedures which document proper packaging protocols; and (2) no trends of routine repackaging of low-level waste that is packaged after issuance of DOE O 435.1. Successful performance of this requirement is also demonstrated by a record of containers for which failure has not routinely occurred under management conditions. It is recognized that there may be failed containers for waste previously placed in storage. For those containers, the goal is to only have to repackage the waste one time after it is retrieved and characterized. Further, acceptable performance is demonstrated by containers of waste having marking and labeling that allows correlation with waste characterization data and container information.)

(a) Low-level waste shall be packaged in a manner that
provides containment and protection for the duration of the
anticipated storage period and until disposal is achieved or
until the waste has been removed from the container.
(b) When waste is packaged, vents or other measures shall
be provided if the potential exists for pressurizing or
generating flammable or explosive concentrations of gases
within the waste container.

(c) Containers of low-level waste shall be marked such that their contents can be identified.

(2) Transportation. To the extent practical, the volume of waste and number of low-level waste shipments shall be minimized.

From DOE G 435.1-1 Chapter IV:

Compliance with this requirement can be demonstrated by a combination of site procedures directing the efficient use of waste container capacity and documentation showing that low-level waste shipments are systematically planned and optimized to the extent practical.

M. Site Evaluation and Facility Design. The following requirements are in addition to those in Chapter I of this Manual.

(1) Site Evaluation. Proposed locations for low-level waste facilities shall be evaluated to identify relevant features that
Not a facility-specific requirement. DOE Manual 435.1-1 §I.1.E(11) applies to field element managers.

MCP-17000 $\S 4$ addresses packaging requirements. Facility Compliance Information

Not a facility-specific requirement. DOE Manual
435.1-1 $\$$ I.1.E(11) applies to field element managers.

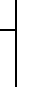

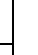


Table 8. (continued).

Facility Name: TRA-678, Radiation Measurements Laboratory

\begin{tabular}{l}
\multicolumn{1}{|c|}{ Chapter IV, LLW Requirements } \\
\hline $\begin{array}{l}\text { should be avoided or must be considered in facility design } \\
\text { and analyses. }\end{array}$ \\
\hline
\end{tabular}

(a) Each site proposed for a new low-level waste facility or expansion of an existing low-level waste facility shall be evaluated considering environmental characteristics, geotechnical characteristics, and human activities, including for a low-level waste disposal facility, the capability of the site to demonstrate, at a minimum, whether it is:

1 Located to accommodate the projected volume of waste to be received;

2 Located in a flood plain, a tectonically active area, or in the zone of water table fluctuation; and

3 Located where radionuclide migration pathways are predictable and erosion and surface runoff can be controlled.

(b) Proposed sites with environmental characteristics, geotechnical characteristics, and human activities for which adequate protection cannot be provided through facility design shall be deemed unsuitable for the location of the facility.

(c) Low-level waste disposal facilities shall be sited to achieve long-term stability and to minimize, to the extent practical, the need for active maintenance following final closure.

(2) Low-Level Waste Treatment and Storage Facility Design. The following facility requirements and general design criteria, at a minimum, apply:

(a) Confinement. Low-level waste systems and components shall be designed to maintain waste confinement.

(b) Ventilation.

1 Design of low-level waste treatment and storage facilities shall include ventilation, if applicable, through an appropriate filtration system to maintain the release of radioactive material in airborne effluents within the requirements and guidelines specified in applicable requirements.

2 When conditions exist for generating gases in flammable or explosive concentrations, ventilation systems or other measures shall be provided to keep the gases in a nonflammable and nonexplosive condition. Where concentrations of explosive or flammable gases are expected to approach the lower flammability limit, measures shall be taken to prevent deflagration or detonation.

(c) Consideration of Decontamination and Decommissioning. Areas in new and modifications to existing low-level waste management facilities that are
Facility Compliance Information

See M. above.

See M. above.

See M. above.

See M. above.

See M. above.

See M. above.

See M. above.

See M. above.

See M. above.

See M. above.

See M. above.

See M. above. 
Table 8. (continued).

Facility Name: TRA-678, Radiation Measurements Laboratory

\begin{tabular}{|c|c|}
\hline Chapter IV, LLW Requirements & Facility Compliance Information \\
\hline $\begin{array}{l}\text { subject to contamination with radioactive or other hazardous } \\
\text { materials shall be designed to facilitate decontamination. } \\
\text { For such facilities a proposed decommissioning method or a } \\
\text { conversion method leading to reuse shall be described. }\end{array}$ & \\
\hline $\begin{array}{l}\text { (d) Instrumentation and Control Systems. Engineering } \\
\text { controls shall be incorporated in the design and engineering } \\
\text { of low-level waste treatment and storage facilities to provide } \\
\text { volume inventory data and to prevent spills, leaks, and } \\
\text { overflows from tanks or confinement systems. }\end{array}$ & See M. above. \\
\hline $\begin{array}{l}\text { (e) Monitoring. Monitoring and/or leak detection } \\
\text { capabilities shall be incorporated in the design and } \\
\text { engineering of low-level waste treatment and storage } \\
\text { facilities to provide rapid identification of failed } \\
\text { confinement and/or other abnormal conditions. }\end{array}$ & See M. above. \\
\hline $\begin{array}{l}\text { (3) Low-Level Waste Disposal Facility Design. The } \\
\text { following facility requirements and general design criteria, } \\
\text { at a minimum, apply: }\end{array}$ & See M. above. \\
\hline $\begin{array}{l}\text { (a) Confinement. Low-level waste systems and components } \\
\text { shall be designed to maintain waste confinement. }\end{array}$ & See M. above. \\
\hline (b) Ventilation. & See M. above. \\
\hline $\begin{array}{l}1 \text { Design of low-level waste disposal facilities shall include } \\
\text { ventilation, if applicable, through an appropriate filtration } \\
\text { system to maintain the release of radioactive material in } \\
\text { airborne effluents within the requirements and guidelines } \\
\text { specified in applicable requirements. }\end{array}$ & See M. above. \\
\hline $\begin{array}{l}2 \text { When conditions exist for generating gases in flammable } \\
\text { or explosive concentrations, ventilation systems or other } \\
\text { measures shall be provided to keep the gases in a non- } \\
\text { flammable and non-explosive condition. Where } \\
\text { concentrations of explosive or flammable gases are expected } \\
\text { to approach the lower flammability limit, measures shall be } \\
\text { taken to prevent deflagration or detonation. }\end{array}$ & See M. above. \\
\hline $\begin{array}{l}\text { (c) Stability. Low-level waste disposal facilities shall be } \\
\text { designed to achieve long-term stability and to minimize to } \\
\text { the extent practical, the need for active maintenance } \\
\text { following final closure. }\end{array}$ & See M. above. \\
\hline $\begin{array}{l}\text { (d) Control of Water. Low-level waste disposal facilities } \\
\text { shall be designed to minimize to the extent practical, the } \\
\text { contact of waste with water during and after disposal. }\end{array}$ & See M. above. \\
\hline $\begin{array}{l}\text { N. Storage and Staging. The following requirements are in } \\
\text { addition to those in Chapter I of this Manual [DOE M } \\
\text { 435.1-1 §I.2.F(13)]. }\end{array}$ & $\begin{array}{l}\text { Not a facility-specific requirement. DOE Manual } \\
435.1-1 \text { §I.2.F(13) applies to field element managers. }\end{array}$ \\
\hline $\begin{array}{l}\text { (1) Storage Prohibitions. Low-level waste in storage shall } \\
\text { not be readily capable of detonation, explosive } \\
\text { decomposition, reaction at anticipated pressures and }\end{array}$ & $\begin{array}{l}\text { NA; this facility does not store LLW. See N. (7) } \\
\text { below for staging requirements. }\end{array}$ \\
\hline
\end{tabular}


Table 8. (continued).

Facility Name: TRA-678, Radiation Measurements Laboratory

\begin{tabular}{l}
\multicolumn{1}{|c|}{ Chapter IV, LLW Requirements } \\
\hline $\begin{array}{l}\text { temperatures, or explosive reaction with water. Prior to } \\
\text { storage, pyrophoric materials shall be treated, prepared, and } \\
\text { packaged to be nonflammable. } \\
\text { From DOE G 435.1-1 Chapter IV: } \\
\text { Compliance with this requirement is demonstrated by } \\
\text { having waste acceptance requirements which prohibit low- } \\
\text { level waste that is ignitable or explosive from being } \\
\text { accepted for storage unless it has been treated, and } \\
\text { procedures for properly preparing such materials for safe } \\
\text { storage. }\end{array}$ \\
\hline
\end{tabular}

(2) Storage Limit. Low-level waste that has an identified path to disposal shall not be stored longer than one year prior to disposal, except for storage for decay, or as otherwise authorized by the Field Element Manager.

From DOE G 435.1-1 Chapter IV:

Storage longer than one year can be justified if the conditions for such storage are approved by the Field Element Manager as part of the radioactive waste management basis for the facility.

Storage for radioactive decay for a period greater than 1 year for waste that has an identified path to disposal is allowed. Adequate justification and the supporting information for storage for decay is to be documented in the radioactive waste management basis for the facility in which the storage will take place.

Mixed waste. Under the Federal Facility Compliance Act of 1992, DOE sites were required to develop Site Treatment Plans to bring stored mixed low-level waste into compliance with these requirements. The Site Treatment Plan needs to be consulted and any mixed low-level waste stored for the purpose of accumulation to facilitate treatment must meet Resource Conservation and Recovery Act storage requirements. There could be several ways within different scenarios that this requirement can be met, as illustrated by the examples below, however, there are basically four ways to show compliance with the requirement and include appropriate provisions in the radioactive waste management basis for the facility in which it is stored.

Legacy waste. As discussed above, the intention of the requirement is not to force malicious compliance or heroic actions which would result in increased risk or safety concerns. Rather, the intention is that waste in storage longer than one year receives additional attention to ensure that the public, the workers, and the environment are protected from the hazards of the waste, and that progress is being made to dispose of the waste. There could be several ways within different scenarios that this requirement can be
See (1) above.
Facility Compliance Information 
Table 8. (continued).

Facility Name: TRA-678, Radiation Measurements Laboratory

met, as illustrated by the examples below, however, there are basically four ways to show compliance with the requirement:

1) the radioactive waste management basis allows for storage for no more than one year.

2) the radioactive waste management basis allows for storage for no more than one year, or for storage for decay only for periods greater than a year, which are specified on a radionuclide basis.

3) the radioactive waste management basis allows for storage for more than one year, up to a specified period of time based on a documented technical evaluation that the waste can be stored in a manner that does not cause changes to the waste or waste packages that is detrimental to the safe storage of the waste, the final disposal of the waste or to meeting the disposal performance objectives.

4) the radioactive waste management basis allows for storage for decay (with specifics) and for storage for more than one year for other low-level waste, up to a specified period of time based on a documented technical evaluation that the waste can be stored in a manner that does not cause changes to the waste or waste packages that is detrimental to the safe storage of the waste, the final disposal of the waste or to meeting the disposal performance objectives.

Compliance with this requirement is demonstrated by the existence of a radioactive waste management basis for the storage facility approved by the Field Element Manager that includes the time frames that waste are allowed to be stored, the necessary justifications for storage for decay, and the necessary technical evaluations if storage is to extend significantly beyond the one-year time frame.

(3) Storage Integrity. Low-level waste shall be stored in a location and manner that protects the integrity of waste for the expected time of storage and minimizes worker exposure.

However, in making a decision to use a facility for storage and in developing a radioactive waste management basis for the activity, particular attention to protection of workers is needed.

From DOE G 435.1-1 Chapter IV:

Compliance with this requirement is demonstrated if sites have storage capabilities for low-level waste that provide protection to waste containers so that their integrity will not be damaged through physical or chemical (corrosion) processes and that keep personnel from spending extended periods of time in the areas where low-level waste is stored. 
Table 8. (continued).

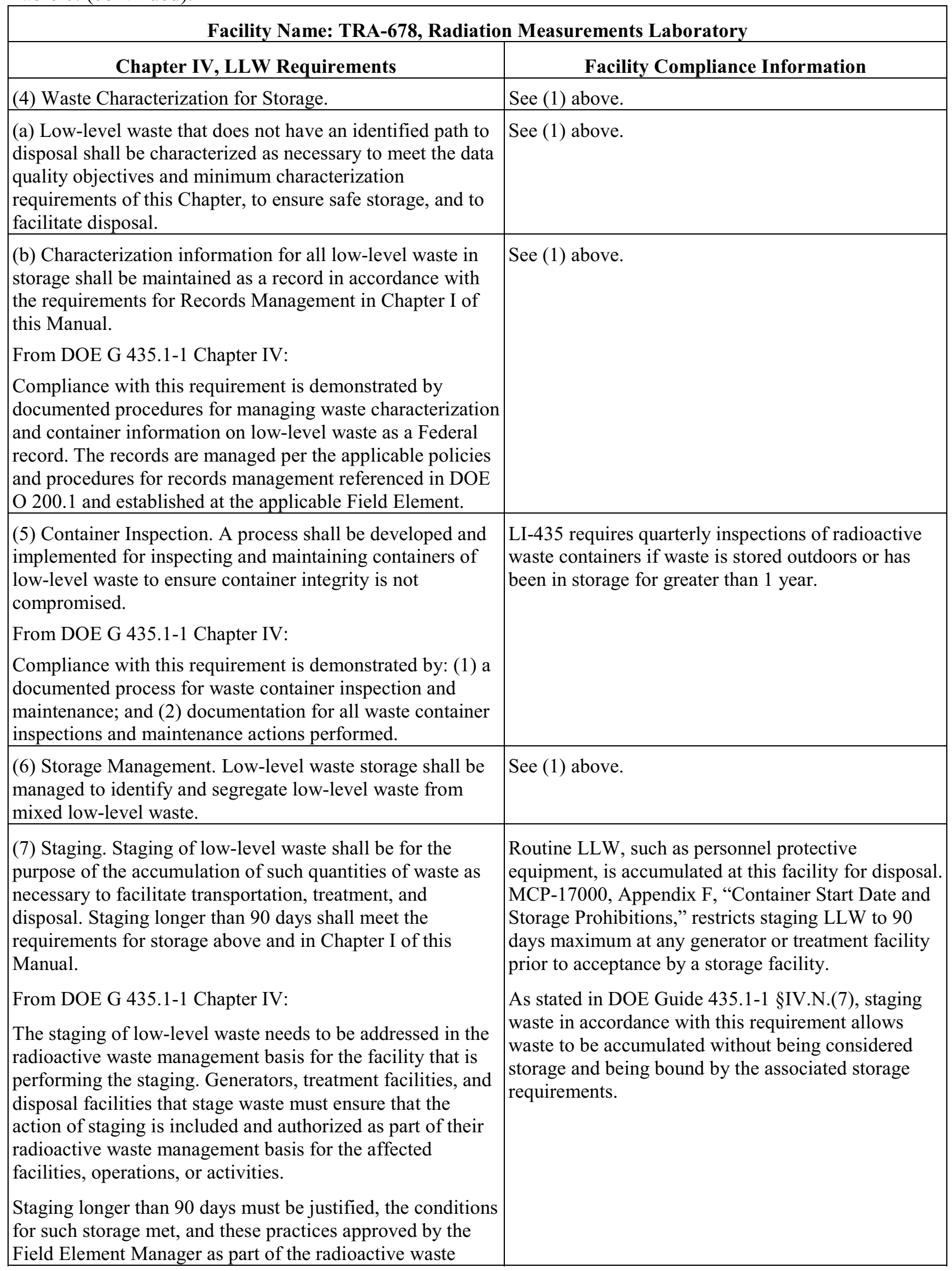


Table 8. (continued).

Facility Name: TRA-678, Radiation Measurements Laboratory

\begin{tabular}{l} 
Chapter IV, LLW Requirements \\
\hline \multicolumn{1}{|c|}{ management basis for the facility. } \\
Compliance with this requirement is demonstrated by a \\
staging program that limits the temporary storage of waste \\
to only circumstances allowed in the requirement, including \\
justifications for any staging that exceeds the 90-day period, \\
which is documented in the radioactive waste management \\
basis for the facility.
\end{tabular}

O. Treatment. Low-level waste treatment to provide more stable waste forms and to improve the long-term performance of a low-level waste disposal facility shall be implemented as necessary to meet the performance objectives of the disposal facility.

From DOE G 435.1-1 Chapter IV:

Compliance with this requirement is demonstrated when a treatment facility or process ensures that treated waste will meet the minimum waste form requirements of DOE M 435.1 and meet additional disposal facility-specific waste acceptance requirements for additional stability or long-term performance of facilities that will receive the treated waste.

P. Disposal. Low-level waste disposal facilities shall meet the following requirements.

(1) Performance Objectives. Low-level waste disposal facilities shall be sited, designed, operated, maintained, and closed so that a reasonable expectation exists that the following performance objectives will be met for waste disposed of after September 26, 1988:

(a) Dose to representative members of the public shall not exceed 25 mrem $(0.25 \mathrm{mSv})$ in a year total effective dose equivalent from all exposure pathways, excluding the dose from radon and its progeny in air.

(b) Dose to representative members of the public via the air pathway shall not exceed $10 \mathrm{mrem}(0.10 \mathrm{mSv})$ in a year total effective dose equivalent, excluding the dose from radon and its progeny.

(c) Release of radon shall be less than an average flux of 20 $\mathrm{pCi} / \mathrm{m}^{2} / \mathrm{s}\left(0.74 \mathrm{~Bq} / \mathrm{m}^{2} / \mathrm{s}\right)$ at the surface of the disposal facility. Alternatively, a limit of $0.5 \mathrm{pCi} / 1(0.0185 \mathrm{~Bq} / \mathrm{l})$ of air may be applied at the boundary of the facility.

(2) Performance Assessment. A site-specific radiological performance assessment shall be prepared and maintained for DOE low-level waste disposed of after September 26, 1988. The performance assessment shall include calculations for a 1,000 year period after closure of potential doses to representative future members of the public and potential releases from the facility to provide a reasonable expectation that the performance objectives identified in this

\begin{tabular}{|l} 
Facility Compliance Information \\
NA; this facility is not a LLW treatment facility.
\end{tabular}

NA; this facility is not a LLW disposal facility.

See P. above

See P. above

See P. above

See P. above

See P. above

Facility Compliance Information
NA; this facility is not a LLW treatment facility.

See P. above

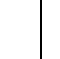


Table 8. (continued).

Facility Name: TRA-678, Radiation Measurements Laboratory

\begin{tabular}{|l|l|}
\hline \multicolumn{1}{|c|}{ Chapter IV, LLW Requirements } & Facility Compliance Information \\
\hline $\begin{array}{l}\text { Chapter are not exceeded as a result of operation and } \\
\text { closure of the facility. }\end{array}$ & \\
\hline
\end{tabular}

(a) Analyses performed to demonstrate compliance with the

See P. above performance objectives in this Chapter, and to establish limits on concentrations of radionuclides for disposal based on the performance measures for inadvertent intruders in this Chapter shall be based on reasonable activities in the critical group of exposed individuals. Unless otherwise specified, the assumption of average living habits and exposure conditions in representative critical groups of individuals projected to receive the highest doses is appropriate. The likelihood of inadvertent intruder scenarios may be considered in interpreting the results of the analyses and establishing radionuclide concentrations, if adequate justification is provided.

(b) The point of compliance shall correspond to the point of highest projected dose or concentration beyond a 100 meter buffer zone surrounding the disposed waste. A larger or smaller buffer zone may be used if adequate justification is provided.

(c) Performance assessments shall address reasonably foreseeable natural processes that might disrupt barriers against release and transport of radioactive materials.

(d) Performance assessments shall use DOE-approved dose coefficients (dose conversion factors) for internal and external exposure of reference adults.

(e) The performance assessment shall include a sensitivity/uncertainty analysis.

(f) Performance assessments shall include a demonstration that projected releases of radionuclides to the environment shall be maintained as low as reasonably achievable (ALARA).

(g) For purposes of establishing limits on radionuclides that may be disposed of near-surface, the performance assessment shall include an assessment of impacts to water resources.

(h) For purposes of establishing limits on the concentration of radionuclides that may be disposed of near-surface, the performance assessment shall include an assessment of impacts calculated for a hypothetical person assumed to inadvertently intrude for a temporary period into the lowlevel waste disposal facility. For intruder analyses, institutional controls shall be assumed to be effective in deterring intrusion for at least 100 years following closure. The intruder analyses shall use performance measures for chronic and acute exposure scenarios, respectively, of 100 mrem $(1 \mathrm{mSv})$ in a year and $500 \mathrm{mrem}(5 \mathrm{mSv})$ total 
Table 8. (continued).

Facility Name: TRA-678, Radiation Measurements Laboratory

\begin{tabular}{|c|c|}
\hline Chapter IV, LLW Requirements & Facility Compliance Information \\
\hline \multicolumn{2}{|l|}{ effective dose equivalent excluding radon in air. } \\
\hline $\begin{array}{l}\text { (3) Composite Analysis. For disposal facilities which } \\
\text { received waste after September } 26,1988 \text {, a site-specific } \\
\text { radiological composite analysis shall be prepared and } \\
\text { maintained that accounts for all sources of radioactive } \\
\text { material that may be left at the DOE site and may interact } \\
\text { with the low- level waste disposal facility, contributing to } \\
\text { the dose projected to a hypothetical member of the public } \\
\text { from the existing or future disposal facilities. Performance } \\
\text { measures shall be consistent with DOE requirements for } \\
\text { protection of the public and environment and evaluated for a } \\
1,000 \text { year period following disposal facility closure. The } \\
\text { composite analysis results shall be used for planning, } \\
\text { radiation protection activities, and future use commitments } \\
\text { to minimize the likelihood that current low- level waste } \\
\text { disposal activities will result in the need for future } \\
\text { corrective or remedial actions to adequately protect the } \\
\text { public and the environment. }\end{array}$ & \begin{tabular}{|l|l|} 
See P. above \\
$\mid$
\end{tabular} \\
\hline $\begin{array}{l}\text { (4) Performance Assessment and Composite Analysis } \\
\text { Maintenance. The performance assessment and composite } \\
\text { analysis shall be maintained to evaluate changes that could } \\
\text { affect the performance, design, and operating bases for the } \\
\text { facility. Performance assessment and composite analysis } \\
\text { maintenance shall include the conduct of research, field } \\
\text { studies, and monitoring needed to address uncertainties or } \\
\text { gaps in existing data. The performance assessment shall be } \\
\text { updated to support the final facility closure. Additional } \\
\text { iterations of the performance assessment and composite } \\
\text { analysis shall be conducted as necessary during the post- } \\
\text { closure period. }\end{array}$ & See P. above \\
\hline $\begin{array}{l}\text { (a) Performance assessments and composite analyses shall } \\
\text { be reviewed and revised when changes in waste forms or } \\
\text { containers, radionuclide inventories, facility design and } \\
\text { operations, closure concepts, or the improved understanding } \\
\text { of the performance of the waste disposal facility in } \\
\text { combination with the features of the site on which it is } \\
\text { located alter the conclusions or the conceptual model(s) of } \\
\text { the existing performance assessment or composite analysis. }\end{array}$ & See P. above \\
\hline $\begin{array}{l}\text { (b) A determination of the continued adequacy of the } \\
\text { performance assessment and composite analysis shall be } \\
\text { made on an annual basis, and shall consider the results of } \\
\text { data collection and analysis from research, field studies, and } \\
\text { monitoring. }\end{array}$ & See P. above \\
\hline $\begin{array}{l}\text { (c) Annual summaries of low-level waste disposal } \\
\text { operations shall be prepared with respect to the conclusions } \\
\text { and recommendations of the performance assessment and } \\
\text { composite analysis and a determination of the need to revise } \\
\text { the performance assessment or composite analysis. }\end{array}$ & See P. above \\
\hline
\end{tabular}


Table 8. (continued).

\begin{tabular}{|c|c|}
\hline \multicolumn{2}{|c|}{ Facility Name: TRA-678, Radiation Measurements Laboratory } \\
\hline Chapter IV, LLW Requirements & Facility Compliance Information \\
\hline $\begin{array}{l}\text { (5) Disposal Authorization. A disposal authorization } \\
\text { statement shall be obtained prior to construction of a new } \\
\text { low-level waste disposal facility. Field Elements with } \\
\text { existing low-level waste disposal facilities shall obtain a } \\
\text { disposal authorization statement in accordance with the } \\
\text { schedule in the Complex-Wide Low-Level Waste } \\
\text { Management Program Plan. The disposal authorization } \\
\text { statement shall be issued based on a review of the facility's } \\
\text { performance assessment, composite analysis, performance } \\
\text { assessment and composite analysis maintenance, } \\
\text { preliminary closure plan, and preliminary monitoring plan. } \\
\text { The disposal authorization statement shall specify the limits } \\
\text { and conditions on construction, design, operations, and } \\
\text { closure of the low-level waste facility based on these } \\
\text { reviews. A disposal authorization statement is a part of the } \\
\text { radioactive waste management basis for a disposal facility. } \\
\text { Failure to obtain a disposal authorization statement by the } \\
\text { implementation date of this Order shall result in shutdown } \\
\text { of the disposal facility. }\end{array}$ & See P. above \\
\hline $\begin{array}{l}\text { (6) Disposal Facility Operations. The disposal facility } \\
\text { design and operation must be consistent with the disposal } \\
\text { facility closure plan and lead to disposal facility closure that } \\
\text { provides a reasonable expectation that performance } \\
\text { objectives will be met. Low-level waste shall be disposed in } \\
\text { such a manner that achieves the performance objectives } \\
\text { stated in this Chapter, consistent with the disposal facility } \\
\text { radiological performance assessment. Additional } \\
\text { requirements include: }\end{array}$ & See P. above \\
\hline $\begin{array}{l}\text { (a) Operating procedures shall be developed and } \\
\text { implemented for low-level waste disposal facilities that } \\
\text { protect the public, workers, and the environment; ensure the } \\
\text { security of the facility; minimize subsidence during and } \\
\text { after waste emplacement; achieve long-term stability and } \\
\text { minimize the need for long-term active maintenance; and } \\
\text { meet the requirements of the closure/post-closure plan. }\end{array}$ & See P. above \\
\hline $\begin{array}{l}\text { (b) Permanent identification markers for disposal } \\
\text { excavations and monitoring wells shall be emplaced. }\end{array}$ & See P. above \\
\hline $\begin{array}{l}\text { (c) Low-level waste placement into disposal units shall } \\
\text { minimize voids between waste containers. Voids within } \\
\text { disposal units shall be filled to the extent practical. } \\
\text { Uncontainerized bulk waste shall also be placed in a manner } \\
\text { that minimizes voids and subsidence. }\end{array}$ & See P. above \\
\hline $\begin{array}{l}\text { (d) Operations are to be conducted so that active waste } \\
\text { disposal operations will not have an adverse effect on any } \\
\text { other disposal units. }\end{array}$ & See P. above. \\
\hline $\begin{array}{l}\text { (e) Operations shall include a process for tracking and } \\
\text { documenting low-level waste placement in the facility by } \\
\text { generator source. }\end{array}$ & See P. above. \\
\hline
\end{tabular}


Table 8. (continued).

\begin{tabular}{|c|c|}
\hline \multicolumn{2}{|c|}{ Facility Name: TRA-678, Radiation Measurements Laboratory } \\
\hline Chapter IV, LLW Requirements & Facility Compliance Information \\
\hline $\begin{array}{l}\text { (7) Alternate Requirements for Low-Level Waste Disposal } \\
\text { Facility Design and Operation. Requirements other than } \\
\text { those set forth in this Section for the design and operation of } \\
\text { a low-level waste disposal facility may be approved on a } \\
\text { specific basis if a reasonable expectation is demonstrated } \\
\text { that the disposal performance objectives will be met. }\end{array}$ & See P. above. \\
\hline $\begin{array}{l}\text { Q. Closure. The following requirements are in addition to } \\
\text { those in Chapter I of this Manual. }\end{array}$ & See (1) below. \\
\hline $\begin{array}{l}\text { (1) Disposal Facility Closure Plans. A preliminary closure } \\
\text { plan shall be developed and submitted to Headquarters for } \\
\text { review with the performance assessment and composite } \\
\text { analysis. The closure plan shall be updated following } \\
\text { issuance of the disposal authorization statement to } \\
\text { incorporate conditions specified in the disposal } \\
\text { authorization statement. Closure plans shall: }\end{array}$ & NA; this facility is not a LLW disposal facility. \\
\hline $\begin{array}{l}\text { (a) Be updated as required during the operational life of the } \\
\text { facility. }\end{array}$ & See (1) above. \\
\hline $\begin{array}{l}\text { (b) Include a description of how the disposal facility will be } \\
\text { closed to achieve long-term stability and minimize the need } \\
\text { for active maintenance following closure and to ensure } \\
\text { compliance with the requirements of DOE } 5400.5 \text {, } \\
\text { Radiation Protection of the Public and the Environment. }\end{array}$ & See (1) above. \\
\hline $\begin{array}{l}\text { (c) Include the total expected inventory of wastes to be } \\
\text { disposed of at the facility over the operational life of the } \\
\text { facility. }\end{array}$ & See (1) above. \\
\hline $\begin{array}{l}\text { (2) Disposal Facility Closure. Closure of a disposal facility } \\
\text { shall occur within a five-year period after it is filled to } \\
\text { capacity, or after the facility is otherwise determined to be } \\
\text { no longer needed. }\end{array}$ & NA; this facility is not a LLW disposal facility. \\
\hline $\begin{array}{l}\text { (a) Prior to facility closure, the final inventory of the low- } \\
\text { level waste disposed in the facility shall be prepared and } \\
\text { incorporated in the performance assessment and composite } \\
\text { analysis which shall be updated to support the closure of the } \\
\text { facility. }\end{array}$ & See (2) above. \\
\hline $\begin{array}{l}\text { (b) A final closure plan shall be prepared based on the final } \\
\text { inventory of waste disposed in the facility, the plan } \\
\text { implemented, and the updated performance assessment and } \\
\text { composite analysis prepared in support of the facility } \\
\text { closure. }\end{array}$ & See (2) above. \\
\hline $\begin{array}{l}\text { (c) Institutional control measures shall be integrated into } \\
\text { land use and stewardship plans and programs, and shall } \\
\text { continue until the facility can be released pursuant to DOE } \\
\text { 5400.5, Radiation Protection of the Public and the } \\
\text { Environment. }\end{array}$ & See (2) above. \\
\hline $\begin{array}{l}\text { (d) The location and use of the facility shall be filed with the } \\
\text { local authorities responsible for land use and zoning. }\end{array}$ & See (2) above. \\
\hline
\end{tabular}


Table 8. (continued).

\begin{tabular}{|c|c|}
\hline \multicolumn{2}{|c|}{ Facility Name: TRA-678, Radiation Measurements Laboratory } \\
\hline Chapter IV, LLW Requirements & Facility Compliance Information \\
\hline $\begin{array}{l}\text { R. Monitoring. The following requirements are in addition } \\
\text { to those in Chapter I of this Manual [DOE M } 435.1-1 \\
\S I .1 . E(7)] \text {. }\end{array}$ & $\begin{array}{l}\text { Not a facility-specific requirement. DOE Manual } \\
435.1-1 \S I .1 . \mathrm{E}(7) \text { applies to field element managers. }\end{array}$ \\
\hline $\begin{array}{l}\text { (1) All Waste Facilities. Parameters that shall be sampled or } \\
\text { monitored, at a minimum, include: temperature, pressure } \\
\text { (for closed systems), radioactivity in ventilation exhaust and } \\
\text { liquid effluent streams, and flammable or explosive } \\
\text { mixtures of gases. Facility monitoring programs shall } \\
\text { include verification that passive and active control systems } \\
\text { have not failed. } \\
\text { From DOE G 435.1-1 Chapter IV: } \\
\text { The minimum parameters specified in the requirement were } \\
\text { selected based on their potential significance for anticipating } \\
\text { and identifying undesirable conditions at low-level waste } \\
\text { management facilities. Each facility's radioactive waste } \\
\text { management basis should include an evaluation of the } \\
\text { applicability and significance of the minimum parameters. } \\
\text { This evaluation also needs to consider additional parameters } \\
\text { to be sampled or monitored to ensure the protection of the } \\
\text { public health, the environment, and the workers. If a } \\
\text { minimum parameter specified in the requirement is deemed } \\
\text { to be not applicable in any way to the active operation of } \\
\text { that facility, then that justification should be included in the } \\
\text { radioactive waste management basis and when approved } \\
\text { constitutes an exemption to the manual. } \\
\text { Verification activities are part of the radioactive waste } \\
\text { management basis as a condition for operation and } \\
\text { documented appropriately. } \\
\text { Compliance with this requirement is demonstrated if } \\
\text { monitoring or sampling for the stated parameters is } \\
\text { performed for all facilities with a precision, accuracy, and } \\
\text { frequency consistent with timely identification of } \\
\text { developing problems and a justification exists in the } \\
\text { approved radioactive waste management basis for those } \\
\text { specified parameters which are not monitored or sampled. }\end{array}$ & $\begin{array}{l}\text { Monitoring requirements at INL radioactive waste } \\
\text { management facilities are tailored for the specific } \\
\text { facility to enable timely indication of developing } \\
\text { problems. Existing radiological control procedures } \\
\text { and assessments are followed/completed to monitor } \\
\text { waste facilities. } \\
\text { LRD-15001 and MCP-139 specify methods and } \\
\text { frequency of radiological control surveys of all } \\
\text { radiological areas. MCP-139 specifies the use of } \\
\text { Form } 441 . \text { A34. This form is referred to as the } \\
\text { "routine sheet" and is to be used by facility } \\
\text { radiological control foremen to list radiological areas } \\
\text { that are to be surveyed, the survey periods, and } \\
\text { methods. }\end{array}$ \\
\hline $\begin{array}{l}\text { (2) Liquid Waste Storage Facilities. For facilities storing } \\
\text { liquid low-level waste, the following shall also be } \\
\text { monitored: liquid level and/or waste volume, and significant } \\
\text { waste chemistry parameters. }\end{array}$ & NA; this facility is not a LLW storage facility. \\
\hline $\begin{array}{l}\text { (3) Disposal Facilities. A preliminary monitoring plan for a } \\
\text { low-level waste disposal facility shall be prepared and } \\
\text { submitted to Headquarters for review with the performance } \\
\text { assessment and composite analysis. The monitoring plan } \\
\text { shall be updated within one year following issuance of the } \\
\text { disposal authorization statement to incorporate and } \\
\text { implement conditions specified in the disposal authorization } \\
\text { statement. }\end{array}$ & NA; this facility is not a LLW disposal facility. \\
\hline
\end{tabular}


Table 8. (continued).

Facility Name: TRA-678, Radiation Measurements Laboratory

\begin{tabular}{|l|l|}
\hline \multicolumn{1}{|c|}{ Chapter IV, LLW Requirements } & \multicolumn{1}{c|}{ Facility Compliance Information } \\
\hline $\begin{array}{l}\text { (a) The site-specific performance assessment and composite } \\
\text { analysis shall be used to determine the media, locations, } \\
\text { radionuclides, and other substances to be monitored. }\end{array}$ & See (3) above. \\
\hline $\begin{array}{l}\text { (b) The environmental monitoring program shall be } \\
\text { designed to include measuring and evaluating releases, } \\
\text { migration of radionuclides, disposal unit subsidence, and } \\
\text { changes in disposal facility and disposal site parameters } \\
\text { which may affect long-term performance. }\end{array}$ & See (3) above. \\
\hline $\begin{array}{l}\text { (c) The environmental monitoring programs shall be capable } \\
\text { of detecting changing trends in performance to allow } \\
\text { application of any necessary corrective action prior to } \\
\text { exceeding the performance objectives in this Chapter. }\end{array}$ & See above. \\
\hline
\end{tabular}




\subsection{TRA-715, Evaporation Ponds}

1. Description: TRA-715, Evaporation Ponds, is a fenced 5-acre lined pond located approximately $1,500 \mathrm{ft}$ east of the ATR Complex. The pond receives and treats the liquid effluent stream resulting primarily from TRA-670 operations. These waste streams result from canal waste water, primary coolant leakage, and activities associated with the ATR power monitoring (N-16) system. The N-16 waste stream is treated by the ATR WWTF system, but this system does not remove tritium. The waste from the ATR WWTF containing tritium and activation and fission products can be sent to TRA-605, or if below the volatile and nonvolatile release limits established by the State of Idaho, released to TRA-715.

The pond is divided into two compartments and each compartment measures $550 \mathrm{ft}$ by $225 \mathrm{ft}$ and is $10 \mathrm{ft}$ deep. The combined volume of both compartments is approximately 17 million gallons. The compartments of the evaporation pond are double lined. Evaporation pond leak detection is by perforated pipes buried between the two liners of the pond that drain into two manholes located in the center of the berm that runs between the two compartments. Effluent management within the pond is performed by opening and closing manually operated liquid effluent isolation valves. The evaporation pond is operated under a Permit to Construct issued by the State of Idaho.

2. Hazard category: Hazard Category 1 Nuclear Facility

3. Radioactive waste management activities at this facility: LLW from routine operations is generated at this facility. Liquid LLW is treated at this facility.

4. RWMB documents/programs:

a) Safety basis/hazard analysis:

- SAR-153, "Upgraded Final Safety Analysis Report for the Advanced Test Reactor"

b) Laboratory-wide:

- Form 441.A34, "INL Radiological Control Required Surveys"

- LI-435, "Waste Management Routine Field Activities"

- LWP-13840, "Management of Issues"

- LWP-14002, "Timeout and Stop Work Authority"

- LWP-17000, "Waste Management"

- MCP-139, "Radiological Surveys"

- MCP-17000, "Waste Generator Services Waste Management"

- MCP-17500, "Waste Generator Services Certification of Waste Shipments to the Nevada Test Site"

- PDD-17000, "Waste Management Program"

- PLN-114, "INL Emergency Plan/RCRA Contingency Plan"

c) Facility-specific:

- OMM-7.6.13.1.12, "Warm Waste Treatment System Operation"

- OMM-7.11.13.1.3, "Evaporation Pond Sampling and Monitoring"

- OMM-7.11.13.8.1, "TRA-605 Warm Waste Treatment Facility Operation"

- OMM-7.11.13.8.2, "Sampling Warm Waste Treatment system Effluent"

- OMM-7.11.13.8.4, "TRA-605 Effluent Radiation Monitor (ERM) Normal Operation"

- OMM-7.11.13.8.9, “TRA-605 Effluent Radiation Monitor (ERM) System ATR Warm Waste Effluent Grab Sample" 
- Permit No. 023-00001, "State of Idaho Permit to Construct an Air Pollution Emitting Source"

- SP-10.6.5.8, "RTC Non-Containerized Wastewater Management and Control"

- SP-10.6.5.10, "RTC Ponds Wastewater Acceptance Criteria"

Table 9 presents the facility compliance information for Chapter IV, "Low-level Waste Requirements."

Table 9. TRA-715, Evaporation Ponds, DOE Manual 435.1-1 low-level waste requirements and facility compliance information.

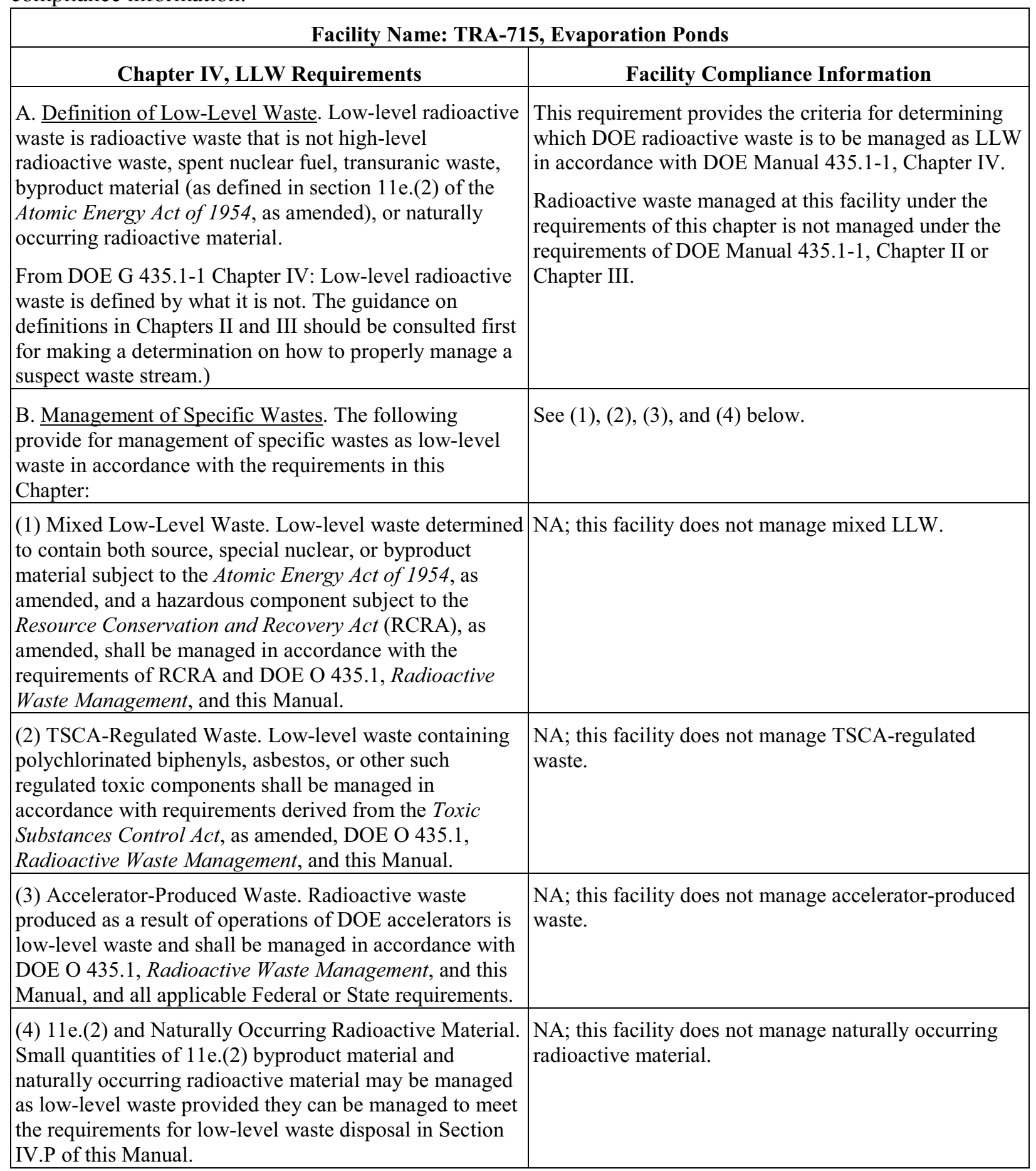


Table 9. (continued).

Facility Name: TRA-715, Evaporation Ponds

\begin{tabular}{|l|}
\hline \multicolumn{1}{|c|}{ Chapter IV, LLW Requirements } \\
\hline $\begin{array}{l}\text { C. Complex-Wide Low-Level Waste Management } \\
\text { Program. A complex-wide program and plan shall be } \\
\text { developed as described under Responsibilities, 2.B and } \\
\text { 2.D, in Chapter I of this Manual. }\end{array}$ \\
\hline
\end{tabular}

D. Radioactive Waste Management Basis. Low-level waste facilities, operations, and activities shall have a radioactive waste management basis consisting of physical and administrative controls to ensure the protection of workers, the public, and the environment. The following specific waste management controls shall be part of the radioactive waste management basis:

(1) Generators. The waste certification program.

From DOE G 435.1-1 Chapter IV: For a facility that generates low-level waste, the radioactive waste management basis is to include the program for certifying that waste meets the waste acceptance requirements of the facility(ies) to which the waste will be sent.

(2) Treatment Facilities. certification program. The waste acceptance requirements and the waste [sic]

From DOE G 435.1-1 Chapter IV: Facilities that store or treat low-level waste are to have approved waste acceptance requirements (see DOE M 435.1-1, Section IV.G) prior to the issuance of a radioactive waste management basis.

A facility that stores or treats waste also is generally expected to have a waste certification program. Waste from these facilities will have to be certified as meeting the waste acceptance requirements of the facility to which it will be transferred, and the facilities have the potential for generating radioactive waste (e.g., secondary processing streams from treatment, monitoring and sampling, radioactive release cleanup). Consequently, storage and treatment facilities should also have an approved waste certification program as part of their radioactive waste management basis.

As part of the radioactive waste management basis, site personnel needs to implement a system or process for tracking the waste inventory at a storage, treatment, or disposal facility.

(3) Storage Facilities. The waste acceptance requirements and the waste certification program.

From DOE G 435.1-1 Chapter IV: Facilities that store or treat low-level waste are to have approved waste acceptance requirements (see DOE M 435.1-1, Section IV.G) prior to the issuance of a radioactive waste

See G. (1) below for waste acceptance requirements.

DOE Manual 435.1-1 §I.2.B and §I.2.D apply to the Assistant Secretary for Environmental Management and the Deputy Assistant Secretary for Waste Management, respectively.

The RWMB provides the regulatory framework for management of radioactive waste at INL. It specifically identifies facility management and implementing documents for the generation, storage, treatment, and disposal of radiological waste.SAR-153 provides the safety basis coverage for this facility as an ancillary system to ATR, which is classified as a Hazard Category 1 nuclear facility.

See J. below for waste certification program requirements.

NA; this facility is not a radioactive waste storage facility. 
Table 9. (continued).

Facility Name: TRA-715, Evaporation Ponds

management basis.

Chapter IV, LLW Requirements

Facility Compliance Information

A facility that stores or treats waste also is generally expected to have a waste certification program. Waste from these facilities will have to be certified as meeting the waste acceptance requirements of the facility to which

it will be transferred, and the facilities have the potential

for generating radioactive waste (e.g., secondary

processing streams from treatment, monitoring and sampling, radioactive release cleanup). Consequently, storage and treatment facilities should also have an approved waste certification program as part of their radioactive waste management basis.

As part of the radioactive waste management basis, site personnel needs to implement a system or process for tracking the waste inventory at a storage, treatment, or disposal facility.

(4) Disposal Facilities. The performance assessment, composite analysis, disposal authorization statement, closure plan, waste acceptance requirements, and monitoring plan.

E. Contingency Actions. The following requirements are in addition to those in Chapter I of this Manual [DOE M 435.1-1 §I.1.E(5)].

NA; this facility is not a radioactive waste disposal facility.

Not a facility-specific requirement. DOE Manual 435.11 §I.1.E(5) addresses the site-wide emergency management system. The INL plan is provided in PLN-114.

(1) Contingency Storage. For off-normal or emergency situations involving high activity or high hazard liquid low-level waste storage or treatment, spare capacity with adequate capabilities shall be maintained to receive the largest volume of liquid contained in any one storage tank or treatment facility. Tanks or other facilities that are designated low-level waste contingency storage shall be maintained in an operational condition when waste is present and shall meet the requirements of DOE O 435.1, Radioactive Waste Management, and this Manual.

From DOE G 435.1-1 Chapter IV: Compliance with these requirements is demonstrated if adequate spare capacity and transfer equipment exists for emergency transfers of all high activity and high hazard liquid low-level waste. In addition, the capability to perform emergency transfers is demonstrated by having waste transfer routings identified, operational procedures to direct transfers, staff trained to the procedures, and records showing that the spare capacity and transfer capability are kept in operating condition.

Documentation of a facility-specific contingency plan or procedure for transfer of the liquid waste disposed of in the evaporation pond to contingency storage in the event of facility upset or an off-normal event was not identified.

SAR-153 $\S$ 11.3.2.5 provides description of TRA-715. The pond is divided into two compartments and each compartment measures $550 \mathrm{ft}$ by $225 \mathrm{ft}$ and is $10 \mathrm{ft}$ deep. The combined volume of both compartments is approximately 17 million gallons.

OMM-7.11.13.8.1 provides operational procedures directing transfers to/from the WWTF to either the west side evaporation pond or the east side evaporation pond.

OMM-7.6.13.1.12 provides operational procedures directing transfers to/from the west side evaporation pond or the east side evaporation pond and prescribes training requirements.

Records regarding staff training to these procedures and maintenance of the transfer capability being kept in operating condition were not identified.

(2) Transfer Equipment. Pipelines and auxiliary facilities necessary for the transfer of high activity or high hazard

OMM-7.11.13.8.1 provides operational procedures directing transfers to/from the WWTF to either the west 
Table 9. (continued).

\section{Facility Name: TRA-715, Evaporation Ponds}

\begin{tabular}{|c|c|}
\hline \multirow{5}{*}{$\begin{array}{l}\text { Chapter IV, LLW Requirements } \\
\text { liquid low-level waste to contingency storage shall be } \\
\text { maintained in an operational condition when waste is } \\
\text { present and shall meet the requirements of DOE O 435.1, } \\
\text { Radioactive Waste Management, and this Manual. } \\
\text { From DOE G 435.1-1 Chapter IV: Compliance with these } \\
\text { requirements is demonstrated if adequate spare capacity } \\
\text { and transfer equipment exists for emergency transfers of } \\
\text { all high activity and high hazard liquid low-level waste. } \\
\text { In addition, the capability to perform emergency transfers } \\
\text { is demonstrated by having waste transfer routings } \\
\text { identified, operational procedures to direct transfers, staff } \\
\text { trained to the procedures, and records showing that the } \\
\text { spare capacity and transfer capability are kept in } \\
\text { operating condition. }\end{array}$} & Facility Compliance Information \\
\hline & side evaporation pond or the east side evaporation pond. \\
\hline & $\begin{array}{l}\text { OMM-7.6.13.1.12 provides operational procedures } \\
\text { directing transfers to/from the west side evaporation } \\
\text { pond or the east side evaporation pond and prescribes }\end{array}$ \\
\hline & training requirements. \\
\hline & $\begin{array}{l}\text { Records regarding staff training to these procedures and } \\
\text { maintenance of the transfer capability being kept in } \\
\text { operating condition were not identified. }\end{array}$ \\
\hline \multirow{4}{*}{$\begin{array}{l}\text { F. Corrective Actions. I of this Manual. The following } \\
\text { requirements are in addition to those in Chapter [sic] } \\
\text { From DOE G 435.1-1 Chapter IV: Compliance with DOE } \\
\text { M 435.1-1 §I.2.G.(1) is demonstrated by records showing } \\
\text { what corrective actions were taken to remedy situations in } \\
\text { the radioactive waste management system. } \\
\text { Compliance with DOE M 435.1-1 §I.2.G.(2) is } \\
\text { demonstrated by having the necessary procedures, } \\
\text { mechanisms, and training in place to effect shutdown or } \\
\text { curtailment of activities which pose an imminent danger } \\
\text { or other serious hazard to workers or the public, or are not } \\
\text { protective of the environment. }\end{array}$} & \multirow{4}{*}{$\begin{array}{l}\text { The INL-wide procedure addressing problem } \\
\text { identification as required by DOE Manual } 435.1-1 \\
\text { §I.2.G.(1) is LWP-13840, which implements the } \\
\text { laboratory's corrective action system. } \\
\text { The INL-wide procedure addressing shutdown or } \\
\text { curtailment of activities as required by DOE } \\
\text { Manual 435.1-1 §I.2.G.(2) is LWP-14002. } \\
\end{array}$} \\
\hline & \\
\hline & \\
\hline & \\
\hline $\begin{array}{l}\text { (1) Order Compliance. Corrective actions shall be } \\
\text { implemented whenever necessary to ensure the } \\
\text { requirements of DOE O } 435.1 \text {, Radioactive Waste } \\
\text { Management, and this Manual are met. }\end{array}$ & \multirow[t]{3}{*}{$\begin{array}{l}\text { A facility-specific procedure that addresses LLW was } \\
\text { not identified. }\end{array}$} \\
\hline $\begin{array}{l}\text { From DOE G } 435.1-1 \text { Chapter IV: If a facility or activity } \\
\text { can be allowed to operate while a noncompliant or } \\
\text { hazardous condition exists, the allowance and any } \\
\text { associated limitations must be defined as part of the } \\
\text { facility or activity's radioactive waste management basis, } \\
\text { identified as a configuration controlled item in a } \\
\text { configuration management plan or included in a revision } \\
\text { or modification to an operating procedure or similar } \\
\text { controlled documentation. }\end{array}$ & \\
\hline $\begin{array}{l}\text { Compliance with this requirement is demonstrated if a } \\
\text { corrective action system addresses noncompliant or } \\
\text { hazardous situations involving low-level waste } \\
\text { management facilities in a systematic fashion, and allows } \\
\text { identification of problems by all personnel. }\end{array}$ & \\
\hline $\begin{array}{l}\text { (2) Operations Curtailment. Operations shall be curtailed } \\
\text { or facilities shut down for failure to establish, maintain, or } \\
\text { operate consistent with an approved radioactive waste }\end{array}$ & $\begin{array}{l}\text { The approved RWMB establishes the current } \\
\text { compliance status at each radioactive waste } \\
\text { management facility. Facility assessments are scheduled }\end{array}$ \\
\hline
\end{tabular}


Table 9. (continued).

Facility Name: TRA-715, Evaporation Ponds

\begin{tabular}{l} 
Chapter IV, LLW Requirements \\
\hline management basis. \\
From DOE G 435.1-1 Chapter IV: Compliance with this \\
requirement is demonstrated with a documented system of \\
routine assessments to determine whether waste \\
management activities and facilities are operating in \\
accordance with an approved radioactive waste \\
management basis that provides for graded limitations \\
that can be placed on activities and operations that do not \\
have, or are operating outside of, an approved radioactive \\
waste management basis, including shutdown of the \\
facility.
\end{tabular}

G. Waste Acceptance. The following requirements are in addition to those in Chapter I of this Manual [DOE M 435.1-1 §I.2.F(6)].

(1) Technical and Administrative. Waste acceptance requirements for all low-level waste storage, treatment, or disposal facilities, operations, and activities shall specify, at a minimum, the following:

From DOE G 435.1-1 Chapter IV: Compliance with these waste acceptance requirements is demonstrated if they are documented, contain clear and precise criteria specifying the radionuclide limits in the form of contents or concentrations that can be accepted, the limitations and prohibitions on waste forms and packages that can be received, and the limits, prohibitions, or instructions concerning any other technical information so that the waste is compatible with the safety basis of the facility, and which will result in acceptable waste at subsequent steps in managing the low-level waste.)

(a) Allowable activities and/or concentrations of specific radionuclides.

(b) Acceptable waste form and/or container requirements that ensure the chemical and physical stability of waste under conditions that might be encountered during transportation, storage, treatment, or disposal.

(c) Restrictions or prohibitions on waste, materials, or containers that may adversely affect waste handlers or compromise facility or waste container performance.

(d) The following are additional waste acceptance requirements that shall be specified in low-level waste disposal facility waste acceptance requirements:

1 Low-level waste must contribute to and not detract from achieving long-term stability of the facility, minimizing the need for long-term active maintenance, minimizing subsidence, and minimizing contact of water with waste. Void spaces within the waste and, if containers are used, between the waste and its container shall be reduced to

\section{Facility Compliance Information}

to ensure waste management activities are conducted in accordance with the approved RWMB.

Not a facility-specific requirement. DOE Manual 435.1$1 \S \mathrm{I} .2 . \mathrm{F}(6)$ applies to field element managers.

Permit No. 023-00001 prescribes the liquid effluent concentration limits for TRA-715. OMM-OMM7.11.13.8.1 $\S 3.6$ and Appendix A provide the acceptance criteria and liquid effluent concentration limits to be met prior to the transfer of TRA- 605 contents to TRA-715.

SP-10.6.5.10 provides the waste acceptance criteria for liquid effluents being discharged to TRA-715.

See (1) above.

See (1) above.

See (1) above.

See (1) above.

$\mathrm{NA}$; this requirement is not applicable to liquid effluent evaporation ponds. 
Table 9. (continued).

Facility Name: TRA-715, Evaporation Ponds

\begin{tabular}{l} 
Chapter IV, LLW Requirements \\
\hline the extent practical. \\
\hline 2 Liquid low-level waste or low-level waste containing \\
free liquid must be converted into a form that contains as \\
little freestanding liquid as is reasonably achievable, but \\
in no case shall the liquid exceed 1 percent of the waste \\
volume when the low-level waste is in a disposal \\
container, or 0.5 percent of the waste volume after it is \\
processed to a stable form.
\end{tabular}

3 Low-level waste must not be readily capable of detonation or of explosive decomposition or reaction at anticipated pressures and temperatures, or of explosive reaction with water. Pyrophoric materials contained in waste shall be treated, prepared, and packaged to be nonflammable.

4 Low-level waste must not contain, or be capable of generating by radiolysis or biodegradation, quantities of toxic gases, vapors, or fumes harmful to the public or workers or disposal facility personnel, or harmful to the long-term structural stability of the disposal site.

5 Low-level waste in a gaseous form must be packaged such that the pressure does not exceed 1.5 atmospheres absolute at $20 \mathrm{C}$. [ sic]

(e) The basis, procedures, and levels of authority required for granting exceptions to the waste acceptance requirements, which shall be contained in each facility's waste acceptance documentation. Each exception request shall be documented, including its disposition as approved or not approved.

From DOE G 435.1-1 Chapter IV: Waste acceptance requirements are acceptable if they are documented and contain a clear description of the procedure and bases for obtaining an exception or deviation to the acceptance criteria for low-level waste to be received at the facility.

(2) Evaluation and Acceptance. The receiving facility shall evaluate waste for acceptance, including confirmation that the technical and administrative requirements have been met. A process for the disposition of non-conforming wastes shall be established.

From DOE G 435.1-1 Chapter IV: Compliance with the waste acceptance requirements for a low-level waste management facility is demonstrated if they include a process for evaluation and acceptance of incoming waste to ensure the acceptance criteria of the facility receiving the waste are met that includes one of or a combination of: (1) testing, sampling, and analysis of representative samples of waste upon receipt; (2) testing, sampling, and analysis of split samples of waste taken at the generator

$\mathrm{NA}$; this requirement is perceived as not applicable to liquid effluent evaporation ponds.

$\mathrm{NA}$; this requirement is perceived as not applicable to liquid effluent evaporation ponds.

\section{See (1) above.}

NA; this requirement is perceived as not applicable to liquid effluent evaporation ponds.

NA; exception from the waste acceptance requirements for this facility has not been pursued.
OMM-7.11.13.8.1 $\S 3.6$ and Appendix A provide the acceptance criteria and liquid effluent concentration limits to be met prior to transfer of TRA-605 contents to TRA-715.

SP-10.6.5.10 provides the waste acceptance criteria for liquid effluents being discharged to TRA-715.

SP-10.6.5.8 addresses review and approval of wastewater discharges made to the ATR Complex pond systems.

OMM-7.11.13.8.2 provides the operational procedure for sample collection.

OMM-7.11.13.8.4 provides sampling of the liquid LLW effluent stream from TRA-605 WWTF prior to 
Table 9. (continued).

Facility Name: TRA-715, Evaporation Ponds

\section{Chapter IV, LLW Requirements}

site; (3) evaluation of testing, sampling, and analysis of data provided by the generator, or (4) audits, reviews, surveillance, or observations of generator waste certification programs and characterization activities. Additionally, acceptable waste acceptance requirements for a storage, treatment or disposal facility will have documented procedures and actions to be taken if a waste that does not conform to the waste acceptance criteria is received at the facility.

\section{H. Waste Generation Planning. The following} requirements are in addition to those in Chapter I of this Manual [DOE M 435.1-1 §I.2.F(7)].

(1) Life-Cycle Planning. Prior to waste generation, planning shall be performed to address the entire life cycle for all low-level waste streams.

From DOE G 435.1-1 Chapter IV: Compliance with this planning requirement is demonstrated by the individual sites establishing a process for evaluating the life-cycle of low-level waste prior to its generation, including the identification of low-level wastes with no path to disposal and appropriate records justifying the newly generated low-level waste stream(s), and site personnel possessing planning information showing the location(s) where lowlevel waste will be stored, treated, and/or disposed along with a confirmation that the personnel managing the facilities agree that the low-level waste may be managed at those facilities.

(2) Waste with No Identified Path to Disposal. Low-level waste streams with no identified path to disposal shall be generated only in accordance with approved conditions which, at a minimum, shall address:

(a) Programmatic need to generate the waste;

(b) Characteristics and issues preventing the disposal of the waste;

(c) Safe storage of the waste until disposal can be achieved; and

(d) Activities and plans for achieving final disposal of the waste.

I. Waste Characterization. Low-level waste shall be characterized using direct or indirect methods, and the characterization documented in sufficient detail to ensure safe management and compliance with the waste acceptance requirements of the facility receiving the waste.

From DOE G 435.1-1 Chapter IV: Compliance with this requirement is demonstrated by a program for
Facility Compliance Information

discharge to TRA-715 via the ERM automated system.

.

Not a facility-specific requirement. DOE Manual 435.1-

1 §I.2.F(7) applies to field element managers.

PDD-17000 and LWP-17000 provide direction to the waste generators for waste generation planning to address the entire life cycle.

This facility is not generating radioactive waste that does not have an identified path to disposal.

See (2) above.

See (2) above.

See (2) above.

See (2) above.

Regarding the liquid low level waste received, OMM-7.11.13.8.1 § 3.6 and Appendix A provide the guidelines and liquid effluent concentration limits to be met prior to transfer of TRA-605 contents to TRA-715.

OMM-7.11.13.8.2 provides the operational procedure for sample collection.

OMM-7.11.13.8.4 provides sampling of the liquid LLW 
Table 9. (continued).

Facility Name: TRA-715, Evaporation Ponds

Chapter IV, LLW Requirements

documenting and the existence of records that document the process for acquiring and verifying the validity of low-level waste characterization data acquired through the use of direct or indirect methods.

\section{Facility Compliance Information}

effluent stream from TRA-605 WWTF prior to discharge to TRA-715 via the ERM automated system.

SP-10.6.5.10 provides the waste acceptance criteria for liquid effluents being discharged to TRA-715.

SP-10.6.5.8 addresses review and approval of wastewater discharges made to ATR Complex pond systems.

Facility-specific procedures addressing management of records regarding the TRA-715 liquid effluents were not identified.

Regarding routine solid LLW streams generated subsequent to TRA-715 operations, MCP-17000 addresses waste characterization. Appendix A shows a process flow diagram that includes waste characterization.

(1) Data Quality Objectives. The data quality objectives process, or a comparable process, shall be used for identifying characterization parameters and acceptable uncertainty in characterization data.

From DOE G 435.1-1 Chapter IV: Compliance with this requirement is demonstrated by the documented use of a data quality objectives or a comparable process for determining the type, quantity, and quality of characterization data needed to safely manage low-level waste.

(2) Minimum Waste Characterization. Characterization data shall, at a minimum, include the following information relevant to the management of the waste:

From DOE G 435.1-1 Chapter IV: Compliance with this requirement is demonstrated by the existence of a program or procedure for determining and records that document characterization of low-level waste consistent with the minimum characterization data requirements.)
Radioactive waste management facilities characterize waste in accordance with the requirements of the receiving storage, treatment, or disposal facility. The documented use of a data quality objectives process, or comparable process, was not identified for this facility.

Regarding the liquid LLW received, OMM-7.11.13.8.1 $\S 3.6$ and Appendix A provide the guidelines and liquid effluent concentration limits to be met prior to transfer of TRA- 605 contents to the TRA-715.

SP-10.6.5.10 provides the waste acceptance criteria for liquid effluents being discharged to TRA-715.

SP-10.6.5.8 addresses review and approval of wastewater discharges made to the ATR Complex pond systems.

OMM-7.11.13.8.2 provides the operational procedure for sample collection.

OMM-7.11.13.8.4 provides sampling of the liquid LLW effluent stream from TRA-605 WWTF prior to discharge to TRA-715 via the ERM automated system.

Facility-specific procedures addressing management of records regarding the TRA-715 WWTF liquid effluents were not identified.

Regarding the routine solid LLW streams generated subsequent to TRA-715 operations, MCP-17000 addresses waste characterization. Appendix A shows a 
Table 9. (continued).

\begin{tabular}{|c|c|}
\hline \multicolumn{2}{|c|}{ Facility Name: TRA-715, Evaporation Ponds } \\
\hline Chapter IV, LLW Requirements & Facility Compliance Information \\
\hline & $\begin{array}{l}\text { process flow diagram that includes waste } \\
\text { characterization. }\end{array}$ \\
\hline \multirow[t]{4}{*}{ (a) Physical and chemical characteristics; } & $\begin{array}{l}\text { Regarding the liquid LLW received, OMM-7.11.13.8.1 } \\
\S 3.6 \text { and Appendix A provide the guidelines and liquid } \\
\text { effluent concentration limits to be met prior to transfer } \\
\text { of TRA- } 605 \text { contents to the TRA- } 715 \text {. }\end{array}$ \\
\hline & $\begin{array}{l}\text { SP-10.6.5.10 provides the waste acceptance criteria for } \\
\text { liquid effluents being discharged to TRA-715. }\end{array}$ \\
\hline & $\begin{array}{l}\text { SP-10.6.5.8 addresses review and approval of } \\
\text { wastewater discharges made to the ATR Complex pond } \\
\text { systems. }\end{array}$ \\
\hline & $\begin{array}{l}\text { Regarding the routine solid LLW streams generated } \\
\text { subsequent to operations, MCP-17000, including } \S \S 4.2 \text {, } \\
4.3 \text {, and } 4.4 \text {, addresses waste characterization. } \\
\text { Information on physical and chemical characteristics is } \\
\text { generally required. }\end{array}$ \\
\hline \multirow[t]{4}{*}{$\begin{array}{l}\text { (b) Volume, including the waste and any stabilization or } \\
\text { absorbent media; }\end{array}$} & $\begin{array}{l}\text { Regarding the liquid LLW received, OMM-7.11.13.8.2 } \\
\S 4.21 \text { and } \S 4.25 \text { prescribe the volumes of liquid effluent } \\
\text { samples to be collected for characterization. }\end{array}$ \\
\hline & $\begin{array}{l}\text { SP-10.6.5.10 provides the waste acceptance criteria for } \\
\text { liquid effluents being discharged to TRA- } 715 \text {. }\end{array}$ \\
\hline & $\begin{array}{l}\text { SP-10.6.5.8 addresses review and approval of } \\
\text { wastewater discharges made to the ATR Complex pond } \\
\text { systems. }\end{array}$ \\
\hline & $\begin{array}{l}\text { Regarding the routine solid LLW streams generated } \\
\text { subsequent to operations, MCP-17000 } \$ 4.2 \text { requires } \\
\text { generator information on the volume of waste expected } \\
\text { to be generated. Information on absorbent media is } \\
\text { required in } \S \S 4.5 \text { and } 4.7 \text {. }\end{array}$ \\
\hline \multirow[t]{2}{*}{ (c) Weight of the container and contents; } & $\begin{array}{l}\text { Regarding the liquid LLW received: The liquid LLW is } \\
\text { not a containerized waste stream; therefore, this } \\
\text { requirement is NA. }\end{array}$ \\
\hline & $\begin{array}{l}\text { Regarding the routine solid LLW streams generated } \\
\text { subsequent to operations, MCP- } 17000 \S 4.7 .8 \text { requires } \\
\text { weight information if waste from different generators is } \\
\text { being consolidated into one container. This is not the } \\
\text { case in TRA-715. }\end{array}$ \\
\hline \multirow[t]{3}{*}{$\begin{array}{l}\text { (d) Identities, activities, and concentrations of major } \\
\text { radionuclides; }\end{array}$} & $\begin{array}{l}\text { Regarding the liquid LLW received, OMM-7.11.13.8.1 } \\
\S 3.6 \text { and Appendix A provide the guidelines and liquid } \\
\text { effluent concentration limits to be met prior to transfer } \\
\text { of TRA-605 contents to TRA-715. }\end{array}$ \\
\hline & $\begin{array}{l}\text { SP-10.6.5.10 provides the waste acceptance criteria for } \\
\text { liquid effluents being discharged to TRA-715. }\end{array}$ \\
\hline & $\begin{array}{l}\text { SP-10.6.5.8 addresses review and approval of } \\
\text { wastewater discharges made to the ATR Complex pond }\end{array}$ \\
\hline
\end{tabular}


Table 9. (continued).

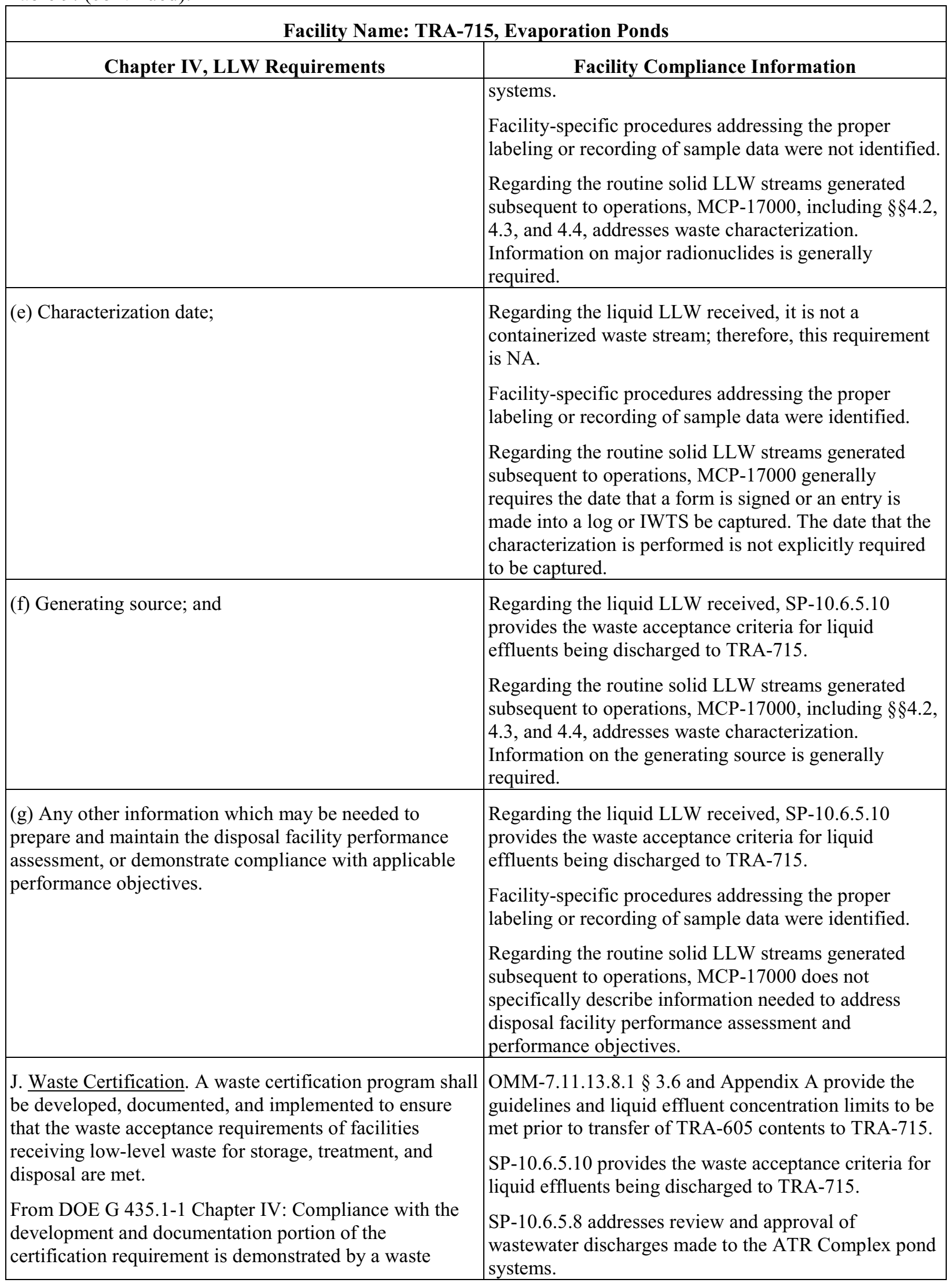


Table 9. (continued).

Facility Name: TRA-715, Evaporation Ponds

\begin{tabular}{|l|}
\hline \multicolumn{1}{|c|}{ Chapter IV, LLW Requirements } \\
\hline certification plan that identifies the organizations \\
involved, assigns responsibilities for implementing the \\
program, and describes or references the quality \\
assurance, training, procurement controls, records \\
management, and procedures to be used by the program. \\
Acceptable performance for implementing the program is \\
demonstrated when appropriate personnel are trained and \\
follow the procedures that govern their part of the waste \\
certification. Additionally, acceptable performance is \\
demonstrated if the waste certification plan and \\
procedures are current and controlled in accordance with \\
a document controls program, and records related to \\
certification (e.g., certification statements, training \\
records, procurement records, characterization records, \\
container records) are generated and managed in \\
accordance with the established site program.
\end{tabular}

Facility Compliance Information

OMM-7.11.13.8.2 provides the operational procedure for sample collection for analysis to ensure the effluent concentration limits are met prior to transfer of TRA-605 contents to TRA-715.

OMM-7.11.13.8.4 provides sample collection via automated system operation.

OMM-7.11.13.8.9 provides sample collection via grab sample.

MCP-17000 cites a waste certification program for LLW destined for NNSS. A waste certification program for other storage, treatment, or disposal facilities is not addressed.

MCP-17500 provides the WGS waste certification program for LLW to be shipped to NNSS. Procurement controls do not appear to be addressed. Also, how the procedure is maintained within the site's document control system is not addressed in the procedure and has not been determined.

Waste certification is performed and tracked using IWTS. Documentation of the IWTS Program is available electronically only.

(1) Certification Program. The waste certification program shall designate the officials who have the authority to certify and release waste for shipment; and specify what documentation is required for waste generation, characterization, shipment, and certification. The program shall provide requirements for auditability, retrievability, and storage of required documentation and specify the records retention period.

From DOE G 435.1-1 Chapter IV: Compliance with this requirement is demonstrated by a program or procedure for record keeping and records showing that low-level waste is certified as having met the waste acceptance criteria of the facility to which it was transferred and that the certification statement is supported by additional records regarding the waste source, characterization, and container.

(2) Certification before Transfer. Low-level waste shall be certified as meeting waste acceptance requirements before it is transferred to the facility receiving the waste.

From DOE G 435.1-1 Chapter IV: Compliance with this requirement is demonstrated by the presence of a certification program which includes procedures requiring a signed certification statement prior to the release of waste for transfer, and by dated records showing that waste was certified before being transferred.

Regarding the liquid LLW received, see J. above.

MCP- $17500 \S \S 2$ and 5 identify which specific records of certification must be obtained and maintained

Waste certification is performed and tracked using IWTS. Documentation of the IWTS Program is available electronically only.

Regarding the liquid LLW received, see (J) above.

Regarding the solid LLW stream generated subsequent to operations, MCP-17500 $\$ 4.3 .6$ provides the controls for certification prior to transfer for LLW destined for disposition at NNSS. 
Table 9. (continued).

Facility Name: TRA-715, Evaporation Ponds

\begin{tabular}{|l|}
\hline \multicolumn{1}{|c|}{ Chapter IV, LLW Requirements } \\
\hline (3) Maintaining Certification. Low-level waste that has \\
been certified as meeting the waste acceptance \\
requirements for transfer to a storage, treatment, or \\
disposal facility shall be managed in a manner that \\
maintains its certification status. \\
From DOE G 435.1-1 Chapter IV: Compliance with this \\
requirement is demonstrated by a program or procedure \\
reflecting this requirement is present and site personnel \\
are able to show that the storage of low-level waste \\
containers is in a facility or manner where the containers \\
would not be damaged by normal weather events, and \\
cannot be accessed by unauthorized personnel. Further, \\
each container can be traced to its certification and the \\
information supporting that certification.
\end{tabular}

K. Waste Transfer. A documented process shall be established and implemented for transferring

responsibility for management of low-level waste and for ensuring availability of relevant data. The following requirements are in addition to those in Chapter I of this Manual.

From DOE G 435.1-1 Chapter IV: Compliance with this requirement is demonstrated if facilities have procedures for the receipt of waste and the transfer of waste, as appropriate, which address the acquisition of waste and container data and the transfer of ownership, respectively. Further evidence of acceptable performance is facility records showing that data on the waste containers is available and accurate, and that documented transfer of responsibility occurs.

(1) Authorization. Low-level waste shall not be transferred to a storage, treatment, or disposal facility until personnel responsible for the facility receiving the waste authorize the transfer.

From DOE G 435.1-1 Chapter IV: Compliance with this requirement is demonstrated by sites having procedures that require a confirmation of authorization before releasing waste for transfer, and records showing that transfers are made in accordance with written authorizations.

(2) Data. Waste characterization data, container information, and generation, storage, treatment, and transportation information for low-level waste shall be transferred with or be traceable to the waste.

From DOE G 435.1-1 Chapter IV: Compliance with this requirement is demonstrated if there are procedures requiring that characterization and container data be provided and maintained for each low-level waste transfer and documented records of transfers show that the information is being provided.

SP-10.6.5.8 provides the wastewater approval process used to identify, review, and approve proposed wastewater discharges to TRA-715.

SP-10.6.5.10 provides the roles and responsibilities for WMA review and approval of effluent streams being discharged to TRA-715.

Regarding the solid LLW stream generated subsequent to operations, a facility-specific procedure for transferring the waste was not identified.

MCP-17000 $\$ 4.8 .15$ specifies requirements for interfacility transfers.

See K. above.

See K. above.

Regarding the liquid LLW received, see (J) above.

Regarding the solid LLW stream generated subsequent operations, MCP-17500 does not appear to address this requirement. 
Table 9. (continued).

Facility Name: TRA-715, Evaporation Ponds

\begin{tabular}{l}
\multicolumn{1}{|c|}{ Chapter IV, LLW Requirements } \\
\hline $\begin{array}{l}\text { L. Packaging and Transportation. The following } \\
\text { requirements are in addition to those in Chapter I of this } \\
\text { Manual [DOE M 435.1-1 §I.1.E(11)]. }\end{array}$ \\
\hline (1) Packaging
\end{tabular}

(1) Packaging. If containers are used:

From DOE G 435.1-1 Chapter IV: Compliance with the packaging requirement is demonstrated by: (1) procedures which document proper packaging protocols; and (2) no trends of routine repackaging of low-level waste that is packaged after issuance of DOE O 435.1. Successful performance of this requirement is also demonstrated by a record of containers for which failure has not routinely occurred under management conditions. It is recognized that there may be failed containers for waste previously placed in storage. For those containers, the goal is to only have to repackage the waste one time after it is retrieved and characterized. Further, acceptable performance is demonstrated by containers of waste having marking and labeling that allows correlation with waste characterization data and container information.)

(a) Low-level waste shall be packaged in a manner that provides containment and protection for the duration of the anticipated storage period and until disposal is achieved or until the waste has been removed from the container.

(b) When waste is packaged, vents or other measures shall be provided if the potential exists for pressurizing or generating flammable or explosive concentrations of gases within the waste container.

(c) Containers of low-level waste shall be marked such that their contents can be identified.

Regarding the liquid LLW received, it is not a containerized waste stream; therefore, this requirement is NA.

(2) Transportation. To the extent practical, the volume of waste and number of low-level waste shipments shall be minimized.

From DOE G 435.1-1 Chapter IV: Compliance with this requirement can be demonstrated by a combination of site procedures directing the efficient use of waste container capacity and documentation showing that low-level waste shipments are systematically planned and optimized to the extent practical.

M. Site Evaluation and Facility Design. The following requirements are in addition to those in Chapter I of this Manual.

(1) Site Evaluation. Proposed locations for low-level waste facilities shall be evaluated to identify relevant features that should be avoided or must be considered in facility design and analyses.

Regarding the liquid LLW received, it is not a containerized waste stream; therefore, this requirement is NA.

Regarding the routine solid LLW streams generated subsequent to operations, MCP-17000 $§ 4.9$ addresses transportation requirements.

$\mathrm{NA}$; this requirement addresses new radioactive waste management facilities.

See M. above. 
Table 9. (continued).

Facility Name: TRA-715, Evaporation Ponds

Chapter IV, LLW Requirements

(a) Each site proposed for a new low-level waste facility or expansion of an existing low-level waste facility shall be evaluated considering environmental characteristics, geotechnical characteristics, and human activities, including for a low-level waste disposal facility, the capability of the site to demonstrate, at a minimum, whether it is:

1 Located to accommodate the projected volume of waste to be received;

2 Located in a flood plain, a tectonically active area, or in the zone of water table fluctuation; and

3 Located where radionuclide migration pathways are predictable and erosion and surface runoff can be controlled.

(b) Proposed sites with environmental characteristics, geotechnical characteristics, and human activities for which adequate protection cannot be provided through facility design shall be deemed unsuitable for the location of the facility.

(c) Low-level waste disposal facilities shall be sited to achieve long-term stability and to minimize, to the extent practical, the need for active maintenance following final closure.

(2) Low-Level Waste Treatment and Storage Facility Design. The following facility requirements and general design criteria, at a minimum, apply:

(a) Confinement. Low-level waste systems and components shall be designed to maintain waste confinement.

(b) Ventilation.

1 Design of low-level waste treatment and storage facilities shall include ventilation, if applicable, through an appropriate filtration system to maintain the release of radioactive material in airborne effluents within the requirements and guidelines specified in applicable requirements.

2 When conditions exist for generating gases in flammable or explosive concentrations, ventilation systems or other measures shall be provided to keep the gases in a non-flammable and nonexplosive condition. Where concentrations of explosive or flammable gases are expected to approach the lower flammability limit, measures shall be taken to prevent deflagration or detonation.

\section{Facility Compliance Information}

See M. above.

See M. above.

See M. above.

See M. above.

See M. above.

See M. above.

See M. above.

See M. above.

See M. above.

See M. above.

See M. above. 
Table 9. (continued).

Facility Name: TRA-715, Evaporation Ponds

Chapter IV, LLW Requirements

(c) Consideration of Decontamination and Decommissioning. Areas in new and modifications to existing low-level waste management facilities that are subject to contamination with radioactive or other hazardous materials shall be designed to facilitate decontamination. For such facilities a proposed decommissioning method or a conversion method leading to reuse shall be described.

(d) Instrumentation and Control Systems. Engineering controls shall be incorporated in the design and engineering of low-level waste treatment and storage facilities to provide volume inventory data and to prevent spills, leaks, and overflows from tanks or confinement systems.

(e) Monitoring. Monitoring and/or leak detection capabilities shall be incorporated in the design and engineering of low-level waste treatment and storage facilities to provide rapid identification of failed confinement and/or other abnormal conditions.

(3) Low-Level Waste Disposal Facility Design. The following facility requirements and general design criteria, at a minimum, apply:

(a) Confinement. Low-level waste systems and components shall be designed to maintain waste confinement.

(b) Ventilation.

1 Design of low-level waste disposal facilities shall include ventilation, if applicable, through an appropriate filtration system to maintain the release of radioactive material in airborne effluents within the requirements and guidelines specified in applicable requirements.

2 When conditions exist for generating gases in flammable or explosive concentrations, ventilation systems or other measures shall be provided to keep the gases in a nonflammable and non-explosive condition. Where concentrations of explosive or flammable gases are expected to approach the lower flammability limit, measures shall be taken to prevent deflagration or detonation.

(c) Stability. Low-level waste disposal facilities shall be designed to achieve long-term stability and to minimize to the extent practical, the need for active maintenance following final closure.

(d) Control of Water. Low-level waste disposal facilities shall be designed to minimize to the extent practical, the contact of waste with water during and after disposal.

\section{Facility Compliance Information}

See M. above.

See M. above.

See M. above.

See M. above.

See M. above.

See M. above.

See M. above.

See M. above.

See M. above.

See M. above. 
Table 9. (continued).

Facility Name: TRA-715, Evaporation Ponds

\begin{tabular}{l}
\hline \multicolumn{1}{c|}{ Chapter IV, LLW Requirements } \\
\hline $\begin{array}{l}\text { N. Storage and Staging. The following requirements are } \\
\text { in addition to those in Chapter I of this Manual [DOE M } \\
\text { 435.1-1 §I.2.F(13)]. } \\
\text { (1) Storage Prohibitions. Low-level waste in storage shal } \\
\text { not be readily capable of detonation, explosive } \\
\text { decomposition, reaction at anticipated pressures and } \\
\text { temperatures, or explosive reaction with water. Prior to } \\
\text { storage, pyrophoric materials shall be treated, prepared, } \\
\text { and packaged to be nonflammable. } \\
\text { From DOE G 435.1-1 Chapter IV: Compliance with this } \\
\text { requirement is demonstrated by having waste acceptance } \\
\text { requirements which prohibit low-level waste that is } \\
\text { ignitable or explosive from being accepted for storage } \\
\text { unless it has been treated, and procedures for properly } \\
\text { preparing such materials for safe storage. }\end{array}$
\end{tabular}

(2) Storage Limit. Low-level waste that has an identified path to disposal shall not be stored longer than one year prior to disposal, except for storage for decay, or as otherwise authorized by the Field Element Manager.

From DOE G 435.1-1 Chapter IV: Storage longer than one year can be justified if the conditions for such storage are approved by the Field Element Manager as part of the radioactive waste management basis for the facility.

Storage for radioactive decay for a period greater than 1 year for waste that has an identified path to disposal is allowed. Adequate justification and the supporting information for storage for decay is to be documented in the radioactive waste management basis for the facility in which the storage will take place.

Mixed waste. Under the Federal Facility Compliance Act of 1992, DOE sites were required to develop Site Treatment Plans to bring stored mixed low-level waste into compliance with these requirements. The Site Treatment Plan needs to be consulted and any mixed lowlevel waste stored for the purpose of accumulation to facilitate treatment must meet Resource Conservation and Recovery Act storage requirements. There could be several ways within different scenarios that this requirement can be met, as illustrated by the examples below, however, there are basically four ways to show compliance with the requirement and include appropriate provisions in the radioactive waste management basis for the facility in which it is stored.

Legacy waste. As discussed above, the intention of the requirement is not to force malicious compliance or heroic actions which would result in increased risk or safety concerns. Rather, the intention is that waste in
NA; this facility is not a LLW storage facility. 
Table 9. (continued).

Facility Name: TRA-715, Evaporation Ponds

Chapter IV, LLW Requirements

storage longer than one year receives additional attention to ensure that the public, the workers, and the environment are protected from the hazards of the waste, and that progress is being made to dispose of the waste. There could be several ways within different scenarios that this requirement can be met, as illustrated by the examples below, however, there are basically four ways to show compliance with the requirement:

1) the radioactive waste management basis allows for storage for no more than one year.

2) the radioactive waste management basis allows for storage for no more than one year, or for storage for decay only for periods greater than a year, which are specified on a radionuclide basis.

3) the radioactive waste management basis allows for storage for more than one year, up to a specified period of time based on a documented technical evaluation that the waste can be stored in a manner that does not cause changes to the waste or waste packages that is detrimental to the safe storage of the waste, the final disposal of the waste or to meeting the disposal performance objectives.

4) the radioactive waste management basis allows for storage for decay (with specifics) and for storage for more than one year for other low-level waste, up to a specified period of time based on a documented technical evaluation that the waste can be stored in a manner that does not cause changes to the waste or waste packages that is detrimental to the safe storage of the waste, the final disposal of the waste or to meeting the disposal performance objectives.

Compliance with this requirement is demonstrated by the existence of a radioactive waste management basis for the storage facility approved by the Field Element Manager that includes the time frames that waste are allowed to be stored, the necessary justifications for storage for decay, and the necessary technical evaluations if storage is to extend significantly beyond the one-year time frame.

(3) Storage Integrity. Low-level waste shall be stored in a NA; this facility is not a LLW storage facility. location and manner that protects the integrity of waste for the expected time of storage and minimizes worker exposure.

However, in making a decision to use a facility for storage and in developing a radioactive waste management basis for the activity, particular attention to protection of workers is needed.

From DOE G 435.1-1 Chapter IV: Compliance with this requirement is demonstrated if sites have storage 
Table 9. (continued).

Facility Name: TRA-715, Evaporation Ponds

\begin{tabular}{l} 
Chapter IV, LLW Requirements \\
\hline \multicolumn{1}{|c|}{ capabilities for low-level waste that provide protection to } \\
waste containers so that their integrity will not be \\
damaged through physical or chemical (corrosion) \\
processes and that keep personnel from spending \\
extended periods of time in the areas where low-level \\
waste is stored. \\
(4) Waste Characterization for Storage. \\
$\begin{array}{l}\text { (a) Low-level waste that does not have an identified path } \\
\text { to disposal shall be characterized as necessary to meet the } \\
\text { data quality objectives and minimum characterization } \\
\text { requirements of this Chapter, to ensure safe storage, and } \\
\text { to facilitate disposal. }\end{array}$ \\
\hline
\end{tabular}

(b) Characterization information for all low-level waste in NA; this facility is not a LLW storage facility. storage shall be maintained as a record in accordance with the requirements for Records Management in Chapter I of this Manual.

From DOE G 435.1-1 Chapter IV: Compliance with this requirement is demonstrated by documented procedures for managing waste characterization and container information on low-level waste as a Federal record. The records are managed per the applicable policies and procedures for records management referenced in DOE O 200.1 and established at the applicable Field Element.

(5) Container Inspection. A process shall be developed and implemented for inspecting and maintaining containers of low-level waste to ensure container integrity is not compromised.

From DOE G 435.1-1 Chapter IV: Compliance with this requirement is demonstrated by: (1) a documented process for waste container inspection and maintenance; and (2) documentation for all waste container inspections and maintenance actions performed.

(6) Storage Management. Low-level waste storage shall be managed to identify and segregate low-level waste from mixed low-level waste.

(7) Staging. Staging of low-level waste shall be for the purpose of the accumulation of such quantities of waste as necessary to facilitate transportation, treatment, and disposal. Staging longer than 90 days shall meet the requirements for storage above and in Chapter I of this Manual.

From DOE G 435.1-1 Chapter IV: The staging of lowlevel waste needs to be addressed in the radioactive waste management basis for the facility that is performing the staging. Generators, treatment facilities, and disposal facilities that stage waste must ensure that the action of staging is included and authorized as part of their

NA; this facility is not a LLW storage facility.

NA; this facility is not a LLW storage facility.

NA; this facility is not a LLW staging facility. NA; this facility is not a LLW storage facility.

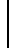


Table 9. (continued).

Facility Name: TRA-715, Evaporation Ponds

\begin{tabular}{|c|c|}
\hline Chapter IV, LLW Requirements & Facility Compliance Information \\
\hline $\begin{array}{l}\text { radioactive waste management basis for the affected } \\
\text { facilities, operations, or activities. }\end{array}$ & \\
\hline $\begin{array}{l}\text { Staging longer than } 90 \text { days must be justified, the } \\
\text { conditions for such storage met, and these practices } \\
\text { approved by the Field Element Manager as part of the } \\
\text { radioactive waste management basis for the facility. }\end{array}$ & \\
\hline $\begin{array}{l}\text { Compliance with this requirement is demonstrated by a } \\
\text { staging program that limits the temporary storage of } \\
\text { waste to only circumstances allowed in the requirement, } \\
\text { including justifications for any staging that exceeds the } \\
90 \text {-day period, which is documented in the radioactive } \\
\text { waste management basis for the facility. }\end{array}$ & \\
\hline $\begin{array}{l}\text { O. Treatment. Low-level waste treatment to provide more } \\
\text { stable waste forms and to improve the long-term } \\
\text { performance of a low-level waste disposal facility shall be } \\
\text { implemented as necessary to meet the performance } \\
\text { objectives of the disposal facility. }\end{array}$ & $\begin{array}{l}\text { NA; Although TRA-715 treats the liquid LLW effluents } \\
\text { from TRA-605, this waste is not transferred to a } \\
\text { separate disposal facility for disposition. Therefore, } \\
\text { there are no "additional disposal facility-specific waste } \\
\text { acceptance requirements" for a receiving facility. }\end{array}$ \\
\hline $\begin{array}{l}\text { From DOE G 435.1-1 Chapter IV: Compliance with this } \\
\text { requirement is demonstrated when a treatment facility or } \\
\text { process ensures that treated waste will meet the minimum } \\
\text { waste form requirements of DOE M } 435.1 \text { and meet } \\
\text { additional disposal facility-specific waste acceptance } \\
\text { requirements for additional stability or long-term } \\
\text { performance of facilities that will receive the treated } \\
\text { waste. }\end{array}$ & \\
\hline $\begin{array}{l}\text { P. Disposal. Low-level waste disposal facilities shall meet } \\
\text { the following requirements. }\end{array}$ & NA; this facility is not a LLW disposal facility. \\
\hline $\begin{array}{l}\text { (1) Performance Objectives. Low-level waste disposal } \\
\text { facilities shall be sited, designed, operated, maintained, } \\
\text { and closed so that a reasonable expectation exists that the } \\
\text { following performance objectives will be met for waste } \\
\text { disposed of after September 26, 1988: }\end{array}$ & See P. above. \\
\hline $\begin{array}{l}\text { (a) Dose to representative members of the public shall not } \\
\text { exceed } 25 \mathrm{mrem}(0.25 \mathrm{mSv}) \text { in a year total effective dose } \\
\text { equivalent from all exposure pathways, excluding the } \\
\text { dose from radon and its progeny in air. }\end{array}$ & See P. above. \\
\hline $\begin{array}{l}\text { (b) Dose to representative members of the public via the } \\
\text { air pathway shall not exceed } 10 \mathrm{mrem}(0.10 \mathrm{mSv}) \text { in a } \\
\text { year total effective dose equivalent, excluding the dose } \\
\text { from radon and its progeny. }\end{array}$ & See P. above. \\
\hline $\begin{array}{l}\text { (c) Release of radon shall be less than an average flux of } \\
20 \mathrm{pCi} / \mathrm{m}^{2} / \mathrm{s}\left(0.74 \mathrm{~Bq} / \mathrm{m}^{2} / \mathrm{s}\right) \text { at the surface of the disposal } \\
\text { facility. Alternatively, a limit of } 0.5 \mathrm{pCi} / 1(0.0185 \mathrm{~Bq} / \mathrm{l}) \text { of } \\
\text { air may be applied at the boundary of the facility. }\end{array}$ & See P. above. \\
\hline $\begin{array}{l}\text { (2) Performance Assessment. A site-specific radiological } \\
\text { performance assessment shall be prepared and maintained }\end{array}$ & See P. above. \\
\hline
\end{tabular}


Table 9. (continued).

Facility Name: TRA-715, Evaporation Ponds

\begin{tabular}{|l|}
\hline \multicolumn{1}{|c|}{ Chapter IV, LLW Requirements } \\
\hline for DOE low-level waste disposed of after September 26, \\
1988. The performance assessment shall include \\
calculations for a 1,000 year period after closure of \\
potential doses to representative future members of the \\
public and potential releases from the facility to provide a \\
reasonable expectation that the performance objectives \\
identified in this Chapter are not exceeded as a result of \\
operation and closure of the facility.
\end{tabular}

(a) Analyses performed to demonstrate compliance with

See P. above

the performance objectives in this Chapter, and to

establish limits on concentrations of radionuclides for

disposal based on the performance measures for

inadvertent intruders in this Chapter shall be based on

reasonable activities in the critical group of exposed

individuals. Unless otherwise specified, the assumption of

average living habits and exposure conditions in

representative critical groups of individuals projected to

receive the highest doses is appropriate. The likelihood of

inadvertent intruder scenarios may be considered in

interpreting the results of the analyses and establishing

radionuclide concentrations, if adequate justification is provided.

(b) The point of compliance shall correspond to the point See P. above of highest projected dose or concentration beyond a 100

meter buffer zone surrounding the disposed waste. A

larger or smaller buffer zone may be used if adequate justification is provided.

(c) Performance assessments shall address reasonably foreseeable natural processes that might disrupt barriers against release and transport of radioactive materials.

(d) Performance assessments shall use DOE-approved dose coefficients (dose conversion factors) for internal and external exposure of reference adults.

(e) The performance assessment shall include a sensitivity/uncertainty analysis.

(f) Performance assessments shall include a Facility Compliance Information

Facility Compliance Information

See P. above

demonstration that projected releases of radionuclides to

the environment shall be maintained as low as reasonably achievable (ALARA).

(g) For purposes of establishing limits on radionuclides that may be disposed of near-surface, the performance assessment shall include an assessment of impacts to water resources.

(h) For purposes of establishing limits on the concentration of radionuclides that may be disposed of near-surface, the performance assessment shall include an assessment of impacts calculated for a hypothetical

See P. above

See P. above

See P. above

See P. above.

See P. above 
Table 9. (continued).

Facility Name: TRA-715, Evaporation Ponds

\begin{tabular}{l} 
Chapter IV, LLW Requirements \\
\hline person assumed to inadvertently intrude for a temporary \\
period into the low-level waste disposal facility. For \\
intruder analyses, institutional controls shall be assumed \\
to be effective in deterring intrusion for at least 100 years \\
following closure. The intruder analyses shall use \\
performance measures for chronic and acute exposure \\
scenarios, respectively, of 100 mrem $(1 \mathrm{mSv})$ in a year \\
and 500 mrem (5 mSv) total effective dose equivalent \\
excluding radon in air.
\end{tabular}

(3) Composite Analysis. For disposal facilities which received waste after September 26, 1988, a site-specific radiological composite analysis shall be prepared and maintained that accounts for all sources of radioactive material that may be left at the DOE site and may interact with the low- level waste disposal facility, contributing to the dose projected to a hypothetical member of the public from the existing or future disposal facilities.

Performance measures shall be consistent with DOE requirements for protection of the public and environment and evaluated for a 1,000 year period following disposal facility closure. The composite analysis results shall be used for planning, radiation protection activities, and future use commitments to minimize the likelihood that current low- level waste disposal activities will result in the need for future corrective or remedial actions to adequately protect the public and the environment.

(4) Performance Assessment and Composite Analysis Maintenance. The performance assessment and composite analysis shall be maintained to evaluate changes that could affect the performance, design, and operating bases for the facility. Performance assessment and composite analysis maintenance shall include the conduct of research, field studies, and monitoring needed to address uncertainties or gaps in existing data. The performance assessment shall be updated to support the final facility closure. Additional iterations of the performance assessment and composite analysis shall be conducted as necessary during the post-closure period.

(a) Performance assessments and composite analyses shall be reviewed and revised when changes in waste forms or containers, radionuclide inventories, facility design and operations, closure concepts, or the improved understanding of the performance of the waste disposal facility in combination with the features of the site on which it is located alter the conclusions or the conceptual model(s) of the existing performance assessment or composite analysis.

(b) A determination of the continued adequacy of the performance assessment and composite analysis shall be

See P. above

See P. above

See P. above

See P. above Facility Compliance Information 
Table 9. (continued).

Facility Name: TRA-715, Evaporation Ponds

\begin{tabular}{|c|c|}
\hline Chapter IV, LLW Requirements & Facility Compliance Information \\
\hline $\begin{array}{l}\text { made on an annual basis, and shall consider the results of } \\
\text { data collection and analysis from research, field studies, } \\
\text { and monitoring. }\end{array}$ & \\
\hline $\begin{array}{l}\text { (c) Annual summaries of low-level waste disposal } \\
\text { operations shall be prepared with respect to the } \\
\text { conclusions and recommendations of the performance } \\
\text { assessment and composite analysis and a determination of } \\
\text { the need to revise the performance assessment or } \\
\text { composite analysis. }\end{array}$ & See P. above \\
\hline $\begin{array}{l}\text { (5) Disposal Authorization. A disposal authorization } \\
\text { statement shall be obtained prior to construction of a new } \\
\text { low-level waste disposal facility. Field Elements with } \\
\text { existing low-level waste disposal facilities shall obtain a } \\
\text { disposal authorization statement in accordance with the } \\
\text { schedule in the Complex-Wide Low-Level Waste } \\
\text { Management Program Plan. The disposal authorization } \\
\text { statement shall be issued based on a review of the } \\
\text { facility's performance assessment, composite analysis, } \\
\text { performance assessment and composite analysis } \\
\text { maintenance, preliminary closure plan, and preliminary } \\
\text { monitoring plan. The disposal authorization statement } \\
\text { shall specify the limits and conditions on construction, } \\
\text { design, operations, and closure of the low-level waste } \\
\text { facility based on these reviews. A disposal authorization } \\
\text { statement is a part of the radioactive waste management } \\
\text { basis for a disposal facility. Failure to obtain a disposal } \\
\text { authorization statement by the implementation date of this } \\
\text { Order shall result in shutdown of the disposal facility. }\end{array}$ & See P. above \\
\hline $\begin{array}{l}\text { (6) Disposal Facility Operations. The disposal facility } \\
\text { design and operation must be consistent with the disposal } \\
\text { facility closure plan and lead to disposal facility closure } \\
\text { that provides a reasonable expectation that performance } \\
\text { objectives will be met. Low-level waste shall be disposed } \\
\text { in such a manner that achieves the performance objectives } \\
\text { stated in this Chapter, consistent with the disposal facility } \\
\text { radiological performance assessment. Additional } \\
\text { requirements include: }\end{array}$ & See P. above \\
\hline $\begin{array}{l}\text { (a) Operating procedures shall be developed and } \\
\text { implemented for low-level waste disposal facilities that } \\
\text { protect the public, workers, and the environment; ensure } \\
\text { the security of the facility; minimize subsidence during } \\
\text { and after waste emplacement; achieve long-term stability } \\
\text { and minimize the need for long-term active maintenance; } \\
\text { and meet the requirements of the closure/post-closure } \\
\text { plan. }\end{array}$ & See P. above \\
\hline $\begin{array}{l}\text { (b) Permanent identification markers for disposal } \\
\text { excavations and monitoring wells shall be emplaced. }\end{array}$ & See P. above \\
\hline
\end{tabular}


Table 9. (continued).

Facility Name: TRA-715, Evaporation Ponds

Chapter IV, LLW Requirements

(c) Low-level waste placement into disposal units shall minimize voids between waste containers. Voids within disposal units shall be filled to the extent practical. Uncontainerized bulk waste shall also be placed in a manner that minimizes voids and subsidence.

(d) Operations are to be conducted so that active waste disposal operations will not have an adverse effect on any other disposal units.

(e) Operations shall include a process for tracking and documenting low-level waste placement in the facility by generator source.

(7) Alternate Requirements for Low-Level Waste Disposal Facility Design and Operation. Requirements other than those set forth in this Section for the design and operation of a low-level waste disposal facility may be approved on a specific basis if a reasonable expectation is demonstrated that the disposal performance objectives will be met.

Q. Closure. The following requirements are in addition to those in Chapter I of this Manual.

(1) Disposal Facility Closure Plans. A preliminary closure NA; this facility is not a LLW disposal facility. plan shall be developed and submitted to Headquarters for review with the performance assessment and composite analysis. The closure plan shall be updated following issuance of the disposal authorization statement to incorporate conditions specified in the disposal authorization statement. Closure plans shall:

(a) Be updated as required during the operational life of the facility.

(b) Include a description of how the disposal facility will be closed to achieve long-term stability and minimize the need for active maintenance following closure and to ensure compliance with the requirements of DOE 5400.5, Radiation Protection of the Public and the Environment.

(c) Include the total expected inventory of wastes to be disposed of at the facility over the operational life of the facility.

(2) Disposal Facility Closure. Closure of a disposal facility shall occur within a five-year period after it is filled to capacity, or after the facility is otherwise determined to be no longer needed.

(a) Prior to facility closure, the final inventory of the lowlevel waste disposed in the facility shall be prepared and incorporated in the performance assessment and composite analysis which shall be updated to support the closure of the facility.
See P. above.

See P. above.

See P. above.

See (1) below.

See (1) above.

See (1) above.

See (1) above.

NA; this facility is not a LLW disposal facility.

See (2) above.

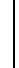

See P. above acility Compliance Information 
Table 9. (continued).

Facility Name: TRA-715, Evaporation Ponds

Chapter IV, LLW Requirements
(b) A final closure plan shall be prepared based on the
final inventory of waste disposed in the facility, the plan
implemented, and the updated performance assessment
and composite analysis prepared in support of the facility
closure.
(c) Institutional control measures shall be integrated into
land use and stewardship plans and programs, and shall
continue until the facility can be released pursuant to
DOE 5400.5, Radiation Protection of the Public and the
Environment.

(d) The location and use of the facility shall be filed with the local authorities responsible for land use and zoning.

R. Monitoring. The following requirements are in addition to those in Chapter I of this Manual [DOE M 435.1-1 §I.1.E(7)].

(1) All Waste Facilities. Parameters that shall be sampled or monitored, at a minimum, include: temperature, pressure (for closed systems), radioactivity in ventilation exhaust and liquid effluent streams, and flammable or explosive mixtures of gases. Facility monitoring programs shall include verification that passive and active control systems have not failed.

From DOE G 435.1-1 Chapter IV: The minimum parameters specified in the requirement were selected based on their potential significance for anticipating and identifying undesirable conditions at low-level waste management facilities. Each facility's radioactive waste management basis should include an evaluation of the applicability and significance of the minimum parameters This evaluation also needs to consider additional parameters to be sampled or monitored to ensure the protection of the public health, the environment, and the workers. If a minimum parameter specified in the requirement is deemed to be not applicable in any way to the active operation of that facility, then that justification should be included in the radioactive waste management basis and when approved constitutes an exemption to the manual.

Verification activities are part of the radioactive waste management basis as a condition for operation and documented appropriately.

Compliance with this requirement is demonstrated if monitoring or sampling for the stated parameters is performed for all facilities with a precision, accuracy, and frequency consistent with timely identification of developing problems and a justification exists in the approved radioactive waste management basis for those specified parameters which are not monitored or sampled.
See (2) above. Facility Compliance Information

See (2) above.

See (2) above.

Not a facility-specific requirement. DOE Manual 435.1$1 \S$ I.1.E(7) applies to field element managers.

Monitoring requirements at INL radioactive waste management facilities are tailored for the specific facility to enable timely indication of developing problems. Existing radiological control procedures and assessments are followed/completed to monitor waste facilities.

OMM-7.11.13.1.3 provides instructions for sampling and monitoring the evaporation ponds in accordance with this permit and other RP documentation. Instructions are covered in this procedure for collecting daily proportional samples, taking pond water level measurements, measuring contamination, and calculating, recording, and reporting the results. This procedure is used on a daily, weekly, monthly, and quarterly basis to perform the monitoring activities required to ensure compliance with the State of Idaho Permit to Construct.

LRD-15001 and MCP-139 specify methods and frequency of radiological control surveys of all radiological areas. MCP-139 specifies the use of Form 441.A34. This form is referred to as the "routine sheet" and is to be used by facility radiological control foremen to list radiological areas that are to be surveyed, the survey periods, and methods. 
Table 9. (continued).

Facility Name: TRA-715, Evaporation Ponds

\begin{tabular}{|l|l|}
\hline \multicolumn{1}{|c|}{ Chapter IV, LLW Requirements } & \multicolumn{1}{|c|}{ Facility Compliance Information } \\
\hline $\begin{array}{l}\text { (2) Liquid Waste Storage Facilities. For facilities storing } \\
\text { liquid low-level waste, the following shall also be } \\
\text { monitored: liquid level and/or waste volume, and } \\
\text { significant waste chemistry parameters. }\end{array}$ & NA; this facility is not a LLW storage facility. \\
\hline $\begin{array}{l}\text { (3) Disposal Facilities. A preliminary monitoring plan for } \\
\text { a low-level waste disposal facility shall be prepared and } \\
\text { submitted to Headquarters for review with the } \\
\text { performance assessment and composite analysis. The } \\
\text { monitoring plan shall be updated within one year } \\
\text { following issuance of the disposal authorization statement } \\
\text { to incorporate and implement conditions specified in the } \\
\text { disposal authorization statement. }\end{array}$ & \\
\hline $\begin{array}{l}\text { (a) The site-specific performance assessment and } \\
\text { composite analysis shall be used to determine the media, a LLW disposal facility. } \\
\text { locations, radionuclides, and other substances to be } \\
\text { monitored. }\end{array}$ & See (3) above. \\
\hline $\begin{array}{l}\text { (b) The environmental monitoring program shall be } \\
\text { designed to include measuring and evaluating releases, } \\
\text { migration of radionuclides, disposal unit subsidence, and } \\
\text { changes in disposal facility and disposal site parameters } \\
\text { which may affect long-term performance. }\end{array}$ & See (3) above. \\
\hline $\begin{array}{l}\text { (c) The environmental monitoring programs shall be } \\
\text { capable of detecting changing trends in performance to } \\
\text { allow application of any necessary corrective action prior } \\
\text { to exceeding the performance objectives in this Chapter. }\end{array}$ & See (3) above. \\
\hline
\end{tabular}

\subsection{TRA-780 (includes TRA-681, 682, 683, and 684), Resource Conservation and Recovery Act 90-Day Storage Area}

1. Facility description: TRA-780 comprises six modular, single-story, steel storage buildings (i.e., TRA-681, 682, 683, 684, 685, 686). The storage buildings are on a concrete pad approximately $44-\mathrm{ft} \times 54-\mathrm{ft} \times 6$-in. thick. The buildings are bolted to the concrete pad at the corners. The interior dimensions are approximately $6 \mathrm{ft} \times 10 \mathrm{ft} 7 \mathrm{in}$. with a height of approximately $7 \mathrm{ft} 3 / 4 \mathrm{in}$. Radioactive waste is managed in TRA-681, 682, 683, and 684. Building TRA-685 is used to store non-waste equipment and TRA-686 is for non-combustible waste only. WGS is the custodian for this facility.

2. Hazard category: LTHC3 (radiological)

3. Radioactive waste managed at this facility: Routine contact-handled LLW (solid), contact-handled LLW (liquid), mixed LLW, and TSCA-regulated LLW is stored at this facility.

4. RWMB documents/programs:

a) Safety basis/hazard analysis:

- HAD-310, "Reactor Technology Complex TRA-780 RCRA 90-Day Storage Area"

- SD-24.1.3, "ATR Complex Facilities and Site Services Safety Basis Administrative Controls" 
b) Laboratory-wide:

- Form 435.A01, "Radioactive Waste Container Inspection Checklist"

- Form 441.A34, "INL Radiological Control Required Surveys"

- Form 450.02, "Waste Management Unit Registration Form"

- Form 450.33, "Temporary Accumulation Area Registration Form"

- LI-435, "Waste Management Routine Field Activities"

- LRD-15001, "Radiological Control Manual"

- LWP-13840, "Management of Issues, Observations, and Noteworthy Practices"

- LWP-14002, "Timeout and Stop Work Authority"

- LWP-15011, "Radioactive Material Areas and Radioactive Storage Areas"

- MCP-139, "Radiological Surveys"

- MCP-17000, "Waste Generator Services Waste Management"

- MCP-17410, "Management of Waste Storage Areas"

- MCP-17500, "Waste Generator Services Certification of Waste Shipments to the Nevada Test Site"

- PDD-17000, "Waste Management Program"

- PLN-114, "INL Emergency Plan/RCRA Contingency Plan"

- PLN-522, "Quality Assurance Program Plan for the Waste Management/Waste Certification Program"

c) Facility-specific:

- IAG-451, "Tenant Use Agreement Between Facility Management Services, Laboratory Support Complex at the Advanced Test Reactor Complex and Waste Generator Services/Energy Solutions in Temporary Waste Management Area Buildings TRA-681, 682, 683, 684, 685, 686 and TRA-780"

- PLN-114-5, "INL Emergency Plan/RCRA Contingency Plan Advanced Test Reactor Complex Appendix L6 TAA TRA-STR-780-1."

Table 10 presents the facility compliance information for Chapter IV, "Low-level Waste Requirements."

Table 10. TRA-780, Resource Conservation and Recovery Act 90-Day Storage Area, DOE Manual 435.1-1 low-level waste requirements and facility compliance information.

\begin{tabular}{|l|l|}
\hline \multicolumn{2}{|c|}{ TRA-780, RCRA 90-Day Storage Area } \\
(Radioactive Waste is Managed in the TRA-681, 682, 683, and 684 Storage Buildings)
\end{tabular}


Table 10. (continued).

\begin{tabular}{|c|c|}
\hline \multicolumn{2}{|c|}{$\begin{array}{l}\text { TRA-780, RCRA 90-Day Storage Area } \\
\text { (Radioactive Waste is Managed in the TRA-681, 682, 683, and 684 Storage Buildings) }\end{array}$} \\
\hline Chapter IV, LLW Requirements & Facility Compliance Information \\
\hline $\begin{array}{l}\text { B. Management of Specific Wastes. The following } \\
\text { provide for management of specific wastes as low-level } \\
\text { waste in accordance with the requirements in this } \\
\text { Chapter: }\end{array}$ & See below. \\
\hline $\begin{array}{l}\text { (1) Mixed Low-Level Waste. Low-level waste } \\
\text { determined to contain both source, special nuclear, or } \\
\text { byproduct material subject to the Atomic Energy Act of } \\
1954 \text {, as amended, and a hazardous component subject to } \\
\text { the Resource Conservation and Recovery Act (RCRA), } \\
\text { as amended, shall be managed in accordance with the } \\
\text { requirements of RCRA and DOE O 435.1, Radioactive } \\
\text { Waste Management, and this Manual. }\end{array}$ & $\begin{array}{l}\text { Mixed waste is managed at this facility. Compliance } \\
\text { with RCRA regulations is addressed by WGS in its } \\
\text { waste management services role in MCP-17000. }\end{array}$ \\
\hline $\begin{array}{l}\text { (2) TSCA-Regulated Waste. Low-level waste containing } \\
\text { polychlorinated biphenyls, asbestos, or other such } \\
\text { regulated toxic components shall be managed in } \\
\text { accordance with requirements derived from the Toxic } \\
\text { Substances Control Act, as amended, DOE O 435.1, } \\
\text { Radioactive Waste Management, and this Manual. }\end{array}$ & $\begin{array}{l}\text { TSCA-regulated waste is managed at this facility. } \\
\text { Compliance with TSCA regulations is addressed by } \\
\text { WGS in its waste management services role in } \\
\text { MCP-17000. }\end{array}$ \\
\hline $\begin{array}{l}\text { (3) Accelerator-Produced Waste. Radioactive waste } \\
\text { produced as a result of operations of DOE accelerators is } \\
\text { low-level waste and shall be managed in accordance with } \\
\text { DOE O 435.1, Radioactive Waste Management, and this } \\
\text { Manual, and all applicable Federal or State requirements. }\end{array}$ & $\begin{array}{l}\text { NA; this facility does not manage accelerator-produced } \\
\text { waste. }\end{array}$ \\
\hline $\begin{array}{l}\text { (4) } 11 \text { e.(2) and Naturally Occurring Radioactive } \\
\text { Material. Small quantities of } 11 \text { e.(2) byproduct material } \\
\text { and naturally occurring radioactive material may be } \\
\text { managed as low-level waste provided they can be } \\
\text { managed to meet the requirements for low-level waste } \\
\text { disposal in Section IV.P of this Manual. }\end{array}$ & $\begin{array}{l}\text { NA; this facility does not manage naturally occurring } \\
\text { radioactive material. }\end{array}$ \\
\hline $\begin{array}{l}\text { C. Complex-Wide Low-Level Waste Management } \\
\text { Program. A complex-wide program and plan shall be } \\
\text { developed as described under Responsibilities, 2.B and } \\
\text { 2.D, in Chapter I of this Manual. }\end{array}$ & $\begin{array}{l}\text { Not a facility-specific requirement. DOE Manual 435.1- } \\
1 \S \text { I.2.B and §I.2.D apply to the Assistant Secretary for } \\
\text { Environmental Management and the Deputy Assistant } \\
\text { Secretary for Waste Management, respectively. }\end{array}$ \\
\hline \multirow{3}{*}{$\begin{array}{l}\text { D. Radioactive Waste Management Basis. Low-level } \\
\text { waste facilities, operations, and activities shall have a } \\
\text { radioactive waste management basis consisting of } \\
\text { physical and administrative controls to ensure the } \\
\text { protection of workers, the public, and the environment. } \\
\text { The following specific waste management controls shall } \\
\text { be part of the radioactive waste management basis: }\end{array}$} & $\begin{array}{l}\text { The RWMB provides the regulatory framework for } \\
\text { management of radioactive waste at INL. It specifically } \\
\text { identifies facility management and implementing } \\
\text { documents for the generation, storage, treatment, and } \\
\text { disposal of radiological waste. }\end{array}$ \\
\hline & This facility is a LTHC3 facility (HAD-310). \\
\hline & $\begin{array}{l}\text { SD-24.1.3 identifies administrative controls, a method of } \\
\text { compliance, and the responsible organization so that the } \\
\text { hazard classification is maintained. }\end{array}$ \\
\hline $\begin{array}{l}\text { (1) Generators. The waste certification program. } \\
\text { From DOE G 435.1-1 Chapter IV: For a facility that } \\
\text { generates low-level waste, the radioactive waste }\end{array}$ & NA; waste is not generated at this facility. \\
\hline
\end{tabular}


Table 10. (continued).

\begin{tabular}{|c|c|}
\hline \multicolumn{2}{|c|}{$\begin{array}{l}\text { TRA-780, RCRA 90-Day Storage Area } \\
\text { (Radioactive Waste is Managed in the TRA-681, 682, 683, and 684 Storage Buildings) }\end{array}$} \\
\hline Chapter IV, LLW Requirements & Facility Compliance Information \\
\hline $\begin{array}{l}\text { management basis is to include the program for } \\
\text { certifying that waste meets the waste acceptance } \\
\text { requirements of the facility(ies) to which the waste will } \\
\text { be sent. }\end{array}$ & \\
\hline $\begin{array}{l}\text { (2) Treatment Facilities. certification program. The waste } \\
\text { acceptance requirements and the waste [sic] }\end{array}$ & NA; waste is not treated at this facility. \\
\hline $\begin{array}{l}\text { From DOE G } 435.1-1 \text { Chapter IV: Facilities that store or } \\
\text { treat low-level waste are to have approved waste } \\
\text { acceptance requirements (see DOE M } 435.1-1 \text {, Section } \\
\text { IV.G) prior to the issuance of a radioactive waste } \\
\text { management basis. }\end{array}$ & \\
\hline $\begin{array}{l}\text { A facility that stores or treats waste also is generally } \\
\text { expected to have a waste certification program. Waste } \\
\text { from these facilities will have to be certified as meeting } \\
\text { the waste acceptance requirements of the facility to } \\
\text { which it will be transferred, and the facilities have the } \\
\text { potential for generating radioactive waste (e.g., } \\
\text { secondary processing streams from treatment, monitoring } \\
\text { and sampling, radioactive release cleanup). } \\
\text { Consequently, storage and treatment facilities should } \\
\text { also have an approved waste certification program as part } \\
\text { of their radioactive waste management basis. }\end{array}$ & \\
\hline $\begin{array}{l}\text { As part of the radioactive waste management basis, site } \\
\text { personnel needs to implement a system or process for } \\
\text { tracking the waste inventory at a storage, treatment, or } \\
\text { disposal facility. }\end{array}$ & \\
\hline $\begin{array}{l}\text { (3) Storage Facilities. The waste acceptance } \\
\text { requirements and the waste certification program. }\end{array}$ & $\begin{array}{l}\text { See G. and J. below for waste acceptance and waste } \\
\text { certification program requirements. }\end{array}$ \\
\hline $\begin{array}{l}\text { From DOE G 435.1-1 Chapter IV: Facilities that store or } \\
\text { treat low-level waste are to have approved waste } \\
\text { acceptance requirements (see DOE M } 435.1-1 \text {, Section } \\
\text { IV.G) prior to the issuance of a radioactive waste } \\
\text { management basis. }\end{array}$ & $\begin{array}{l}\text { HAD-310 establishes the facility as a LTHC } 3 \text { facility } \\
\text { and requires the facility manager to implement a method } \\
\text { of tracking and controlling the radioactive material } \\
\text { inventory so that the sum-of-the-ratios does not exceed } \\
\text { 1. }\end{array}$ \\
\hline $\begin{array}{l}\text { A facility that stores or treats waste also is generally } \\
\text { expected to have a waste certification program. Waste } \\
\text { from these facilities will have to be certified as meeting }\end{array}$ & $\begin{array}{l}\text { SD-24.1.3 Appendix B addresses the use of IWTS to } \\
\text { track the radionuclide quantity limits and the } \\
\text { establishment of an alarm/warning limit in IWTS. }\end{array}$ \\
\hline $\begin{array}{l}\text { the waste acceptance requirements of the facility to } \\
\text { which it will be transferred, and the facilities have the } \\
\text { potential for generating radioactive waste (e.g., } \\
\text { secondary processing streams from treatment, monitoring } \\
\text { and sampling, radioactive release cleanup). } \\
\text { Consequently, storage and treatment facilities should } \\
\text { also have an approved waste certification program as part } \\
\text { of their radioactive waste management basis. }\end{array}$ & $\begin{array}{l}\text { MCP- } 17000 \S 4 \text { specifies the use of IWTS that tracks the } \\
\text { waste inventory. }\end{array}$ \\
\hline $\begin{array}{l}\text { As part of the radioactive waste management basis, site } \\
\text { personnel needs to implement a system or process for }\end{array}$ & \\
\hline
\end{tabular}


Table 10. (continued).

\begin{tabular}{|c|c|}
\hline \multicolumn{2}{|c|}{$\begin{array}{l}\text { TRA-780, RCRA 90-Day Storage Area } \\
\text { (Radioactive Waste is Managed in the TRA-681, 682, 683, and 684 Storage Buildings) }\end{array}$} \\
\hline Chapter IV, LLW Requirements & Facility Compliance Information \\
\hline $\begin{array}{l}\text { tracking the waste inventory at a storage, treatment, or } \\
\text { disposal facility. }\end{array}$ & \\
\hline $\begin{array}{l}\text { (4) Disposal Facilities. The performance assessment, } \\
\text { composite analysis, disposal authorization statement, } \\
\text { closure plan, waste acceptance requirements, and } \\
\text { monitoring plan. }\end{array}$ & NA; this facility is not a disposal facility. \\
\hline $\begin{array}{l}\text { E. Contingency Actions. The following requirements are } \\
\text { in addition to those in Chapter I of this Manual [DOE M } \\
\text { 435.1-1 §I.1.E(5)]. }\end{array}$ & $\begin{array}{l}\text { Not a facility-specific requirement. DOE Manual 435.1- } \\
1 \text { §I.1.E(5) addresses the sitewide emergency } \\
\text { management system. The INL plan is provided in } \\
\text { PLN-114. }\end{array}$ \\
\hline $\begin{array}{l}\text { (1) Contingency Storage. For off-normal or emergency } \\
\text { situations involving high activity or high hazard liquid } \\
\text { low-level waste storage or treatment, spare capacity with } \\
\text { adequate capabilities shall be maintained to receive the } \\
\text { largest volume of liquid contained in any one storage } \\
\text { tank or treatment facility. Tanks or other facilities that } \\
\text { are designated low-level waste contingency storage shall } \\
\text { be maintained in an operational condition when waste is } \\
\text { present and shall meet the requirements of DOE O 435.1, } \\
\text { Radioactive Waste Management, and this Manual. }\end{array}$ & $\begin{array}{l}\text { NA; this facility does not store or treat liquid waste in } \\
\text { tanks. }\end{array}$ \\
\hline $\begin{array}{l}\text { From DOE G } 435.1-1 \text { Chapter IV: Compliance with } \\
\text { these requirements is demonstrated if adequate spare } \\
\text { capacity and transfer equipment exists for emergency } \\
\text { transfers of all high activity and high hazard liquid low- } \\
\text { level waste. In addition, the capability to perform } \\
\text { emergency transfers is demonstrated by having waste } \\
\text { transfer routings identified, operational procedures to } \\
\text { direct transfers, staff trained to the procedures, and } \\
\text { records showing that the spare capacity and transfer } \\
\text { capability are kept in operating condition. }\end{array}$ & \\
\hline $\begin{array}{l}\text { (2) Transfer Equipment. Pipelines and auxiliary facilities } \\
\text { necessary for the transfer of high activity or high hazard } \\
\text { liquid low-level waste to contingency storage shall be } \\
\text { maintained in an operational condition when waste is } \\
\text { present and shall meet the requirements of DOE O 435.1, } \\
\text { Radioactive Waste Management, and this Manual. }\end{array}$ & $\begin{array}{l}\text { NA; this facility does not store or treat liquid waste in } \\
\text { tanks. }\end{array}$ \\
\hline $\begin{array}{l}\text { From DOE G } 435.1-1 \text { Chapter IV: Compliance with } \\
\text { these requirements is demonstrated if adequate spare } \\
\text { capacity and transfer equipment exists for emergency } \\
\text { transfers of all high activity and high hazard liquid low- } \\
\text { level waste. In addition, the capability to perform } \\
\text { emergency transfers is demonstrated by having waste } \\
\text { transfer routings identified, operational procedures to } \\
\text { direct transfers, staff trained to the procedures, and } \\
\text { records showing that the spare capacity and transfer } \\
\text { capability are kept in operating condition. }\end{array}$ & \\
\hline F. Corrective Actions. I of this Manual. The following & The INL-wide procedure addressing problem \\
\hline
\end{tabular}


Table 10. (continued).

\begin{tabular}{|c|c|}
\hline \multicolumn{2}{|c|}{$\begin{array}{l}\text { TRA-780, RCRA 90-Day Storage Area } \\
\text { (Radioactive Waste is Managed in the TRA-681, 682, 683, and 684 Storage Buildings) }\end{array}$} \\
\hline Chapter IV, LLW Requirements & Facility Compliance Information \\
\hline requirements are in addition to those in Chapter [sic] & identification as required by DOE Manual 435.1-1 \\
\hline From DOE G 435.1-1 Chapter IV: Compliance with & $\begin{array}{l}\text { §I.2.G.(1) is LWP-13840, which implements the } \\
\text { laboratory’s corrective action system. }\end{array}$ \\
\hline $\begin{array}{l}\text { showing what corrective actions were taken to remedy } \\
\text { situations in the radioactive waste management system. }\end{array}$ & $\begin{array}{l}\text { The INL-wide procedure addressing shutdown or } \\
\text { curtailment of activities as required by DOE }\end{array}$ \\
\hline $\begin{array}{l}\text { Compliance with DOE M } 435.1-1 \text { II.2.G.(2) is } \\
\text { demonstrated by having the necessary procedures, } \\
\text { mechanisms, and training in place to effect shutdown or } \\
\text { curtailment of activities which pose an imminent danger } \\
\text { or other serious hazard to workers or the public, or are } \\
\text { not protective of the environment. }\end{array}$ & Manual 435.1-1 §I.2.G.(2) is LWP-14002. \\
\hline $\begin{array}{l}\text { (1) Order Compliance. Corrective actions shall be } \\
\text { implemented whenever necessary to ensure the } \\
\text { requirements of DOE O } 435.1 \text {, Radioactive Waste } \\
\text { Management, and this Manual are met. }\end{array}$ & See F. above. \\
\hline $\begin{array}{l}\text { From DOE G } 435.1-1 \text { Chapter IV: If a facility or activity } \\
\text { can be allowed to operate while a noncompliant or } \\
\text { hazardous condition exists, the allowance and any } \\
\text { associated limitations must be defined as part of the } \\
\text { facility or activity's radioactive waste management basis, } \\
\text { identified as a configuration controlled item in a } \\
\text { configuration management plan or included in a revision } \\
\text { or modification to an operating procedure or similar } \\
\text { controlled documentation. }\end{array}$ & \\
\hline $\begin{array}{l}\text { Compliance with this requirement is demonstrated if a } \\
\text { corrective action system addresses noncompliant or } \\
\text { hazardous situations involving low-level waste } \\
\text { management facilities in a systematic fashion, and allows } \\
\text { identification of problems by all personnel. }\end{array}$ & \\
\hline $\begin{array}{l}\text { (2) Operations Curtailment. Operations shall be curtailed } \\
\text { or facilities shut down for failure to establish, maintain, } \\
\text { or operate consistent with an approved radioactive waste } \\
\text { management basis. }\end{array}$ & $\begin{array}{l}\text { The approved RWMB establishes the current } \\
\text { compliance status at each radioactive waste management } \\
\text { facility. Facility assessments are scheduled to ensure } \\
\text { waste management activities are conducted in }\end{array}$ \\
\hline $\begin{array}{l}\text { From DOE G 435.1-1 Chapter IV: Compliance with this } \\
\text { requirement is demonstrated with a documented system } \\
\text { of routine assessments to determine whether waste } \\
\text { management activities and facilities are operating in } \\
\text { accordance with an approved radioactive waste } \\
\text { management basis that provides for graded limitations } \\
\text { that can be placed on activities and operations that do not } \\
\text { have, or are operating outside of, an approved radioactive } \\
\text { waste management basis, including shutdown of the } \\
\text { facility. }\end{array}$ & accordance with the approved RWMB. \\
\hline $\begin{array}{l}\text { G. Waste Acceptance. The following requirements are in } \\
\text { addition to those in Chapter I of this Manual [DOE M } \\
435.1-1 \text { §I.2.F(6)]. }\end{array}$ & $\begin{array}{l}\text { Not a facility-specific requirement. DOE Manual 435.1- } \\
1 \text { §I.2.F(6) applies to field element managers. }\end{array}$ \\
\hline
\end{tabular}


Table 10. (continued).

\begin{tabular}{|c|c|}
\hline \multicolumn{2}{|c|}{$\begin{array}{l}\text { TRA-780, RCRA 90-Day Storage Area } \\
\text { (Radioactive Waste is Managed in the TRA-681, 682, 683, and 684 Storage Buildings) }\end{array}$} \\
\hline Chapter IV, LLW Requirements & Facility Compliance Information \\
\hline $\begin{array}{l}\text { (1) Technical and Administrative. Waste acceptance } \\
\text { requirements for all low-level waste storage, treatment, } \\
\text { or disposal facilities, operations, and activities shall } \\
\text { specify, at a minimum, the following: }\end{array}$ & $\begin{array}{l}\text { HAD- } 310 \text { establishes the facility as a LTHC } 3 \text { facility } \\
\text { and requires a method of tracking and controlling the } \\
\text { radioactive material inventory so that the sum-of-the- } \\
\text { ratios does not exceed } 1 \text {. }\end{array}$ \\
\hline $\begin{array}{l}\text { From DOE G 435.1-1 Chapter IV: Compliance with } \\
\text { these waste acceptance requirements is demonstrated if } \\
\text { they are documented, contain clear and precise criteria } \\
\text { specifying the radionuclide limits in the form of contents }\end{array}$ & $\begin{array}{l}\text { SD-24.1.3, Appendix A provides the procedure for } \\
\text { ensuring that stored waste limits are not exceeded and } \\
\text { delegates this responsibility to the storage area } \\
\text { custodian. }\end{array}$ \\
\hline $\begin{array}{l}\text { or concentrations that can be accepted, the limitations } \\
\text { and prohibitions on waste forms and packages that can } \\
\text { be received, and the limits, prohibitions, or instructions }\end{array}$ & $\begin{array}{l}\text { IAG-451 establishes WGS as the custodian. } \\
\text { Appendix A, Article II, outlines requirements for } \\
\text { controlling radiological material inventories. }\end{array}$ \\
\hline $\begin{array}{l}\text { waste is compatible with the safety basis of the facility, } \\
\text { and which will result in acceptable waste at subsequent } \\
\text { steps in managing the low-level waste. }\end{array}$ & $\begin{array}{l}\text { The storage area custodian manages LLW in accordance } \\
\text { with MCP-17000. Temporary accumulation areas and } \\
\text { management of polychlorinated biphenyl waste are } \\
\text { managed under MCP-17410. Requirements for } \\
\text { registering the storage areas include listing the } \\
\text { emergency plan Appendix L information. Forms } 450.02 \\
\text { and } 450.33 \text { are used to register storage areas. }\end{array}$ \\
\hline & $\begin{array}{l}\text { PLN-114-5 documents the waste type and forms that are } \\
\text { to be stored in the area. }\end{array}$ \\
\hline $\begin{array}{l}\text { (a) Allowable activities and/or concentrations of specific } \\
\text { radionuclides. }\end{array}$ & See (1) above. \\
\hline $\begin{array}{l}\text { (b) Acceptable waste form and/or container requirements } \\
\text { that ensure the chemical and physical stability of waste } \\
\text { under conditions that might be encountered during } \\
\text { transportation, storage, treatment, or disposal. }\end{array}$ & See (1) above. \\
\hline $\begin{array}{l}\text { (c) Restrictions or prohibitions on waste, materials, or } \\
\text { containers that may adversely affect waste handlers or } \\
\text { compromise facility or waste container performance. }\end{array}$ & See (1) above. \\
\hline $\begin{array}{l}\text { (d) The following are additional waste acceptance } \\
\text { requirements that shall be specified in low-level waste } \\
\text { disposal facility waste acceptance requirements: }\end{array}$ & NA; this facility is not a LLW disposal facility. \\
\hline $\begin{array}{l}1 \text { Low-level waste must contribute to and not detract } \\
\text { from achieving long-term stability of the facility, } \\
\text { minimizing the need for long-term active maintenance, } \\
\text { minimizing subsidence, and minimizing contact of water } \\
\text { with waste. Void spaces within the waste and, if } \\
\text { containers are used, between the waste and its container } \\
\text { shall be reduced to the extent practical. }\end{array}$ & See (d) above. \\
\hline $\begin{array}{l}2 \text { Liquid low-level waste or low-level waste containing } \\
\text { free liquid must be converted into a form that contains as } \\
\text { little freestanding liquid as is reasonably achievable, but } \\
\text { in no case shall the liquid exceed } 1 \text { percent of the waste } \\
\text { volume when the low-level waste is in a disposal } \\
\text { container, or } 0.5 \text { percent of the waste volume after it is } \\
\text { processed to a stable form. }\end{array}$ & See (d) above. \\
\hline
\end{tabular}


Table 10. (continued).

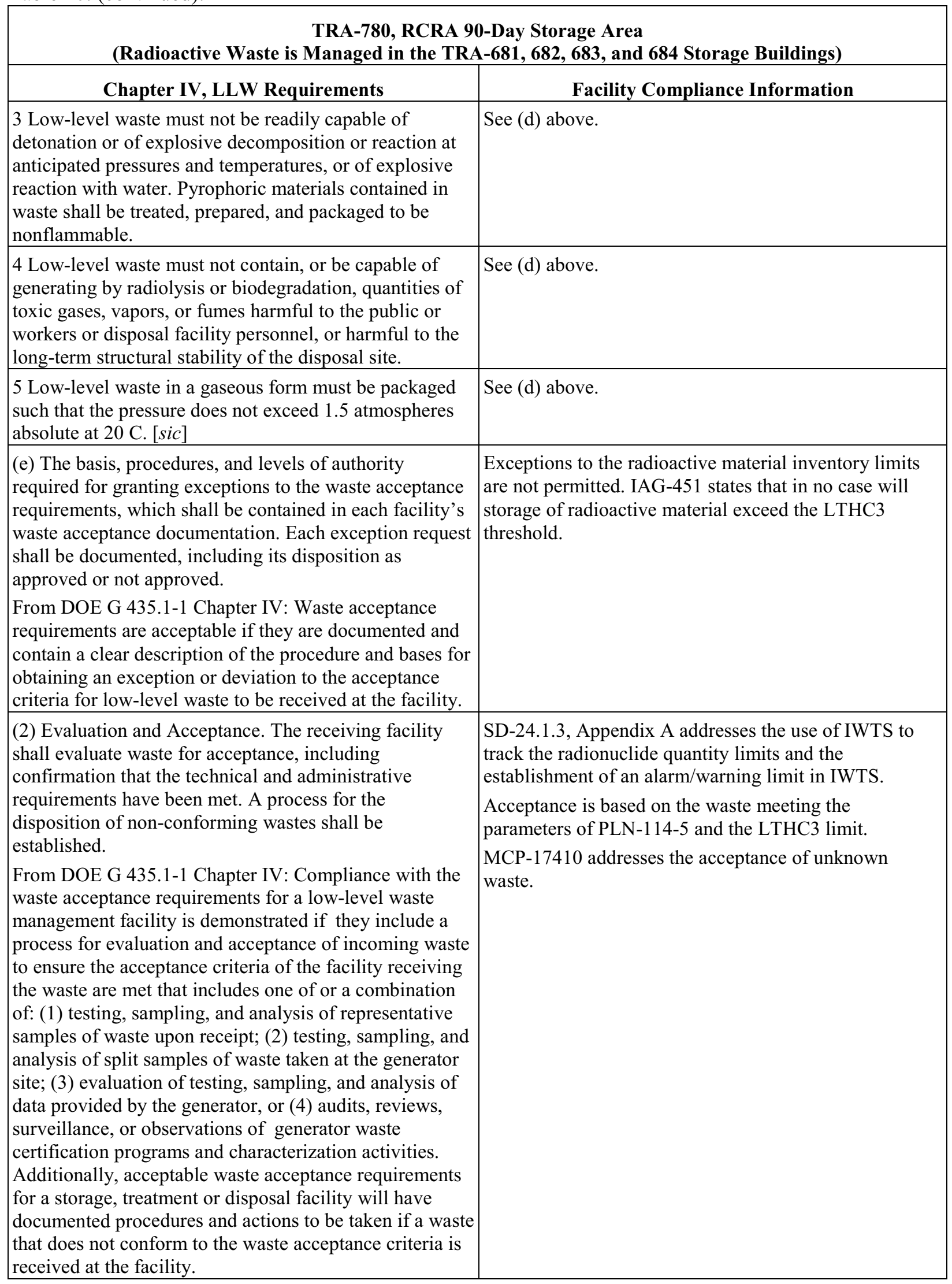


Table 10. (continued).

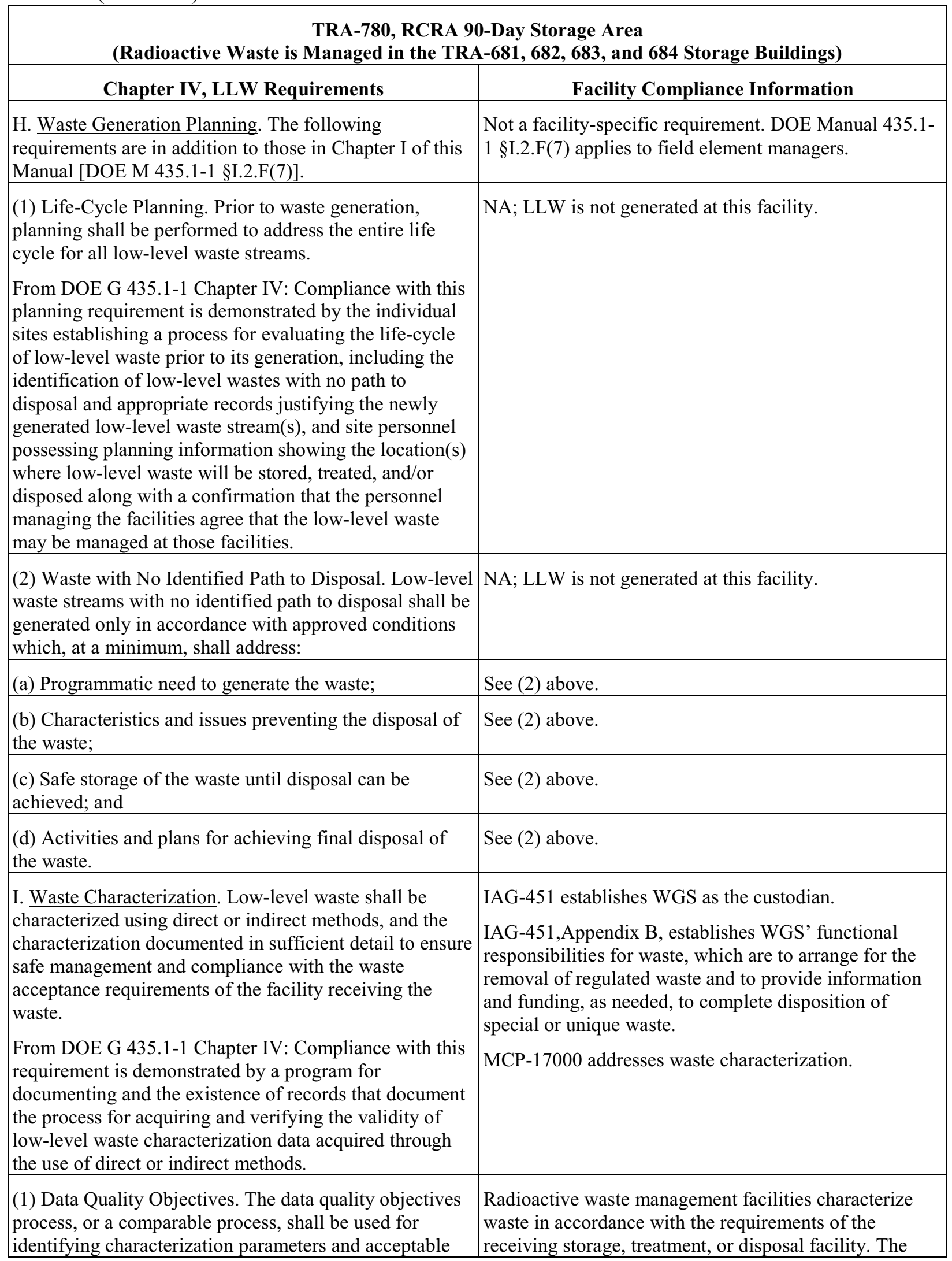


Table 10. (continued).

\begin{tabular}{|c|c|}
\hline \multicolumn{2}{|c|}{$\begin{array}{l}\text { TRA-780, RCRA 90-Day Storage Area } \\
\text { (Radioactive Waste is Managed in the TRA-681, 682, 683, and 684 Storage Buildings) }\end{array}$} \\
\hline Chapter IV, LLW Requirements & Facility Compliance Information \\
\hline $\begin{array}{l}\text { uncertainty in characterization data. } \\
\text { From DOE G } 435.1-1 \text { Chapter IV: Compliance with this } \\
\text { requirement is demonstrated by the documented use of a } \\
\text { data quality objectives or a comparable process for } \\
\text { determining the type, quantity, and quality of } \\
\text { characterization data needed to safely manage low-level } \\
\text { waste. }\end{array}$ & $\begin{array}{l}\text { documented use of a data quality objectives process, or } \\
\text { comparable process, was not identified for this facility. }\end{array}$ \\
\hline $\begin{array}{l}\text { (2) Minimum Waste Characterization. Characterization } \\
\text { data shall, at a minimum, include the following } \\
\text { information relevant to the management of the waste: } \\
\text { From DOE G } 435.1-1 \text { Chapter IV: Compliance with this } \\
\text { requirement is demonstrated by the existence of a } \\
\text { program or procedure for determining and records that } \\
\text { document characterization of low-level waste consistent } \\
\text { with the minimum characterization data requirements. }\end{array}$ & $\begin{array}{l}\text { MCP- } 17000 \text {, including } \S \S 4.2,4.3 \text {, and } 4.4 \text {, provides } \\
\text { waste characterization requirements. Information on } \\
\text { absorbent media is required in } \S \S 4.5 \text { and } 4.7 \text {. } \\
\text { MCP- } 17000 \text { also specifies the use of IWTS, which } \\
\text { documents characterization data in an IWTS profile. }\end{array}$ \\
\hline (a) Physical and chemical characteristics; & See (2) above. \\
\hline $\begin{array}{l}\text { (b) Volume, including the waste and any stabilization or } \\
\text { absorbent media; }\end{array}$ & See (2) above. \\
\hline (c) Weight of the container and contents; & See (2) above. \\
\hline $\begin{array}{l}\text { (d) Identities, activities, and concentrations of major } \\
\text { radionuclides; }\end{array}$ & See (2) above. \\
\hline (e) Characterization date; & See (2) above. \\
\hline (f) Generating source; and & See (2) above. \\
\hline $\begin{array}{l}\text { (g) Any other information which may be needed to } \\
\text { prepare and maintain the disposal facility performance } \\
\text { assessment, or demonstrate compliance with applicable } \\
\text { performance objectives. }\end{array}$ & See (2) above. \\
\hline $\begin{array}{l}\text { J. Waste Certification. A waste certification program } \\
\text { shall be developed, documented, and implemented to } \\
\text { ensure that the waste acceptance requirements of } \\
\text { facilities receiving low-level waste for storage, treatment, } \\
\text { and disposal are met. } \\
\text { From DOE G } 435.1-1 \text { Chapter IV: Compliance with the } \\
\text { development and documentation portion of the } \\
\text { certification requirement is demonstrated by a waste } \\
\text { certification plan that identifies the organizations } \\
\text { involved, assigns responsibilities for implementing the } \\
\text { program, and describes or references the quality } \\
\text { assurance, training, procurement controls, records } \\
\text { management, and procedures to be used by the program. } \\
\text { Acceptable performance for implementing the program is } \\
\text { demonstrated when appropriate personnel are trained and } \\
\text { follow the procedures that govern their part of the waste } \\
\text { certification. Additionally, acceptable performance is }\end{array}$ & $\begin{array}{l}\text { MCP-17000 cites a waste certification program for LLW } \\
\text { destined for NNSS. For waste destined for locations } \\
\text { other than NNSS, the waste disposition specialist is } \\
\text { responsible for certifying the waste stream by ensuring } \\
\text { the waste, as characterized, falls within the limitations of } \\
\text { the waste acceptance criteria of the treatment, storage, or } \\
\text { disposal facility }(\$ 2) \text {. } \\
\text { Container procurement is addressed in MCP-17000 } \$ 4.6 . \\
\text { MCP-17500 provides the WGS waste certification } \\
\text { program for LLW to be shipped to NNSS. } \\
\text { Waste certification is performed and tracked using } \\
\text { IWTS. Documentation of the IWTS Program is available } \\
\text { electronically only. } \\
\text { PLN-522 requires waste technical specialists and waste } \\
\text { disposition specialists to complete the appropriate }\end{array}$ \\
\hline
\end{tabular}


Table 10. (continued).

\begin{tabular}{|c|c|}
\hline \multicolumn{2}{|c|}{$\begin{array}{l}\text { TRA-780, RCRA 90-Day Storage Area } \\
\text { (Radioactive Waste is Managed in the TRA-681, 682, 683, and 684 Storage Buildings) }\end{array}$} \\
\hline Chapter IV, LLW Requirements & Facility Compliance Information \\
\hline $\begin{array}{l}\text { demonstrated if the waste certification plan and } \\
\text { procedures are current and controlled in accordance with } \\
\text { a document controls program, and records related to } \\
\text { certification (e.g., certification statements, training } \\
\text { records, procurement records, characterization records, } \\
\text { container records) are generated and managed in } \\
\text { accordance with the established site program. }\end{array}$ & $\begin{array}{l}\text { training/qualification before being granted approval } \\
\text { authority for profiles within the IWTS Program. The } \\
\text { waste certification official, alternate waste certification } \\
\text { official, and NNSS packaging certifiers must complete } \\
\text { the appropriate training/qualifications to disposition } \\
\text { waste to NNSS. }\end{array}$ \\
\hline $\begin{array}{l}\text { (1) Certification Program. The waste certification } \\
\text { program shall designate the officials who have the } \\
\text { authority to certify and release waste for shipment; and } \\
\text { specify what documentation is required for waste } \\
\text { generation, characterization, shipment, and certification. } \\
\text { The program shall provide requirements for auditability, } \\
\text { retrievability, and storage of required documentation and } \\
\text { specify the records retention period. }\end{array}$ & $\begin{array}{l}\text { See J. above. MCP- } 17500 \S \S 2,5 \text { address certification } \\
\text { records for shipments to NNSS. }\end{array}$ \\
\hline $\begin{array}{l}\text { From DOE G } 435.1-1 \text { Chapter IV: Compliance with this } \\
\text { requirement is demonstrated by a program or procedure } \\
\text { for record keeping and records showing that low-level } \\
\text { waste is certified as having met the waste acceptance } \\
\text { criteria of the facility to which it was transferred and that } \\
\text { the certification statement is supported by additional } \\
\text { records regarding the waste source, characterization, and } \\
\text { container. }\end{array}$ & \\
\hline $\begin{array}{l}\text { (2) Certification before Transfer. Low-level waste shall } \\
\text { be certified as meeting waste acceptance requirements } \\
\text { before it is transferred to the facility receiving the waste. }\end{array}$ & $\begin{array}{l}\text { See J. above. MCP- } 17500 \S 4.3 .6 \text { addresses controls for } \\
\text { certification before transfer for LLW to be disposed of at } \\
\text { NNSS. }\end{array}$ \\
\hline $\begin{array}{l}\text { From DOE G } 435.1-1 \text { Chapter IV: Compliance with this } \\
\text { requirement is demonstrated by the presence of a } \\
\text { certification program which includes procedures } \\
\text { requiring a signed certification statement prior to the } \\
\text { release of waste for transfer, and by dated records } \\
\text { showing that waste was certified before being } \\
\text { transferred. }\end{array}$ & \\
\hline $\begin{array}{l}\text { (3) Maintaining Certification. Low-level waste that has } \\
\text { been certified as meeting the waste acceptance } \\
\text { requirements for transfer to a storage, treatment, or }\end{array}$ & $\begin{array}{l}\text { See J. above. Pre-certification checklists are cited in } \\
\text { MCP-17000 and MCP-17500. Surveillances also are } \\
\text { addressed in MCP-17500. }\end{array}$ \\
\hline $\begin{array}{l}\text { disposal facility shall be managed in a manner that } \\
\text { maintains its certification status. }\end{array}$ & $\begin{array}{l}\text { LWP- } 15011 \S 5 \text { provides general radioactive storage area } \\
\text { requirements and } \$ 5.1 .7 \text { addresses outdoor storage of }\end{array}$ \\
\hline $\begin{array}{l}\text { From DOE G 435.1-1 Chapter IV: Compliance with this } \\
\text { requirement is demonstrated by a program or procedure } \\
\text { reflecting this requirement is present and site personnel } \\
\text { are able to show that the storage of low-level waste } \\
\text { containers is in a facility or manner where the containers } \\
\text { would not be damaged by normal weather events, and } \\
\text { cannot be accessed by unauthorized personnel. Further, } \\
\text { each container can be traced to its certification and the } \\
\text { information supporting that certification. }\end{array}$ & radioactive material. \\
\hline
\end{tabular}


Table 10. (continued).

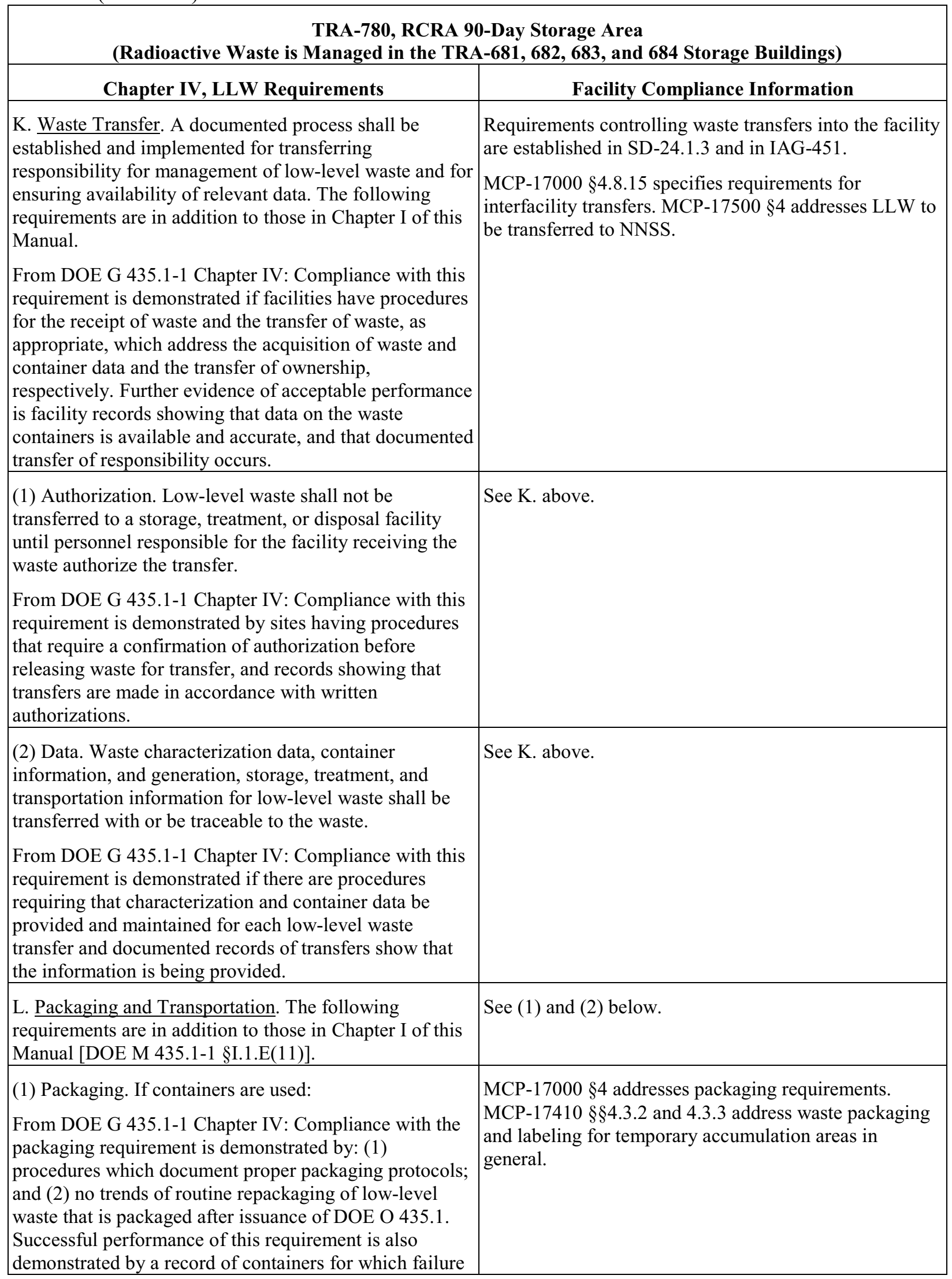


Table 10. (continued).

\begin{tabular}{|c|c|}
\hline \multicolumn{2}{|c|}{$\begin{array}{l}\text { TRA-780, RCRA 90-Day Storage Area } \\
\text { (Radioactive Waste is Managed in the TRA-681, 682, 683, and 684 Storage Buildings) }\end{array}$} \\
\hline Chapter IV, LLW Requirements & Facility Compliance Information \\
\hline $\begin{array}{l}\text { has not routinely occurred under management conditions. } \\
\text { It is recognized that there may be failed containers for } \\
\text { waste previously placed in storage. For those containers, } \\
\text { the goal is to only have to repackage the waste one time } \\
\text { after it is retrieved and characterized. Further, acceptable } \\
\text { performance is demonstrated by containers of waste } \\
\text { having marking and labeling that allows correlation with } \\
\text { waste characterization data and container information. }\end{array}$ & \\
\hline $\begin{array}{l}\text { (a) Low-level waste shall be packaged in a manner that } \\
\text { provides containment and protection for the duration of } \\
\text { the anticipated storage period and until disposal is } \\
\text { achieved or until the waste has been removed from the } \\
\text { container. }\end{array}$ & See (1) above. \\
\hline $\begin{array}{l}\text { (b) When waste is packaged, vents or other measures } \\
\text { shall be provided if the potential exists for pressurizing } \\
\text { or generating flammable or explosive concentrations of } \\
\text { gases within the waste container. }\end{array}$ & See (1) above. \\
\hline $\begin{array}{l}\text { (c) Containers of low-level waste shall be marked such } \\
\text { that their contents can be identified. }\end{array}$ & See (1) above. \\
\hline $\begin{array}{l}\text { (2) Transportation. To the extent practical, the volume of } \\
\text { waste and number of low-level waste shipments shall be } \\
\text { minimized. }\end{array}$ & $\begin{array}{l}\text { MCP- } 17000 \S 4 \text { addresses transportation. The waste } \\
\text { disposition specialist coordinates with packaging and } \\
\text { transportation personnel for waste shipped offsite from }\end{array}$ \\
\hline $\begin{array}{l}\text { From DOE G } 435.1-1 \text { Chapter IV: Compliance with this } \\
\text { requirement can be demonstrated by a combination of } \\
\text { site procedures directing the efficient use of waste } \\
\text { container capacity and documentation showing that low- } \\
\text { level waste shipments are systematically planned and } \\
\text { optimized to the extent practical. }\end{array}$ & $\begin{array}{l}\text { this facility. } \\
\text { Waste is shipped directly to NNSS from this facility. } \\
\text { MCP-17500 specifies waste certification official and } \\
\text { waste disposition specialist responsibilities and } \\
\text { coordination with packaging and transportation } \\
\text { personnel. }\end{array}$ \\
\hline $\begin{array}{l}\text { M. Site Evaluation and Facility Design. The following } \\
\text { requirements are in addition to those in Chapter I of this } \\
\text { Manual. }\end{array}$ & $\begin{array}{l}\text { NA; this requirement addresses new radioactive waste } \\
\text { management facilities or modifications to existing } \\
\text { facilities. }\end{array}$ \\
\hline $\begin{array}{l}\text { (1) Site Evaluation. Proposed locations for low-level } \\
\text { waste facilities shall be evaluated to identify relevant } \\
\text { features that should be avoided or must be considered in } \\
\text { facility design and analyses. }\end{array}$ & See M. above. \\
\hline $\begin{array}{l}\text { (a) Each site proposed for a new low-level waste facility } \\
\text { or expansion of an existing low-level waste facility shall } \\
\text { be evaluated considering environmental characteristics, } \\
\text { geotechnical characteristics, and human activities, } \\
\text { including for a low-level waste disposal facility, the } \\
\text { capability of the site to demonstrate, at a minimum, } \\
\text { whether it is: }\end{array}$ & See M. above. \\
\hline $\begin{array}{l}1 \text { Located to accommodate the projected volume of } \\
\text { waste to be received; }\end{array}$ & See M. above. \\
\hline 2 Located in a flood plain, a tectonically active area, or & See M. above. \\
\hline
\end{tabular}


Table 10. (continued).

\begin{tabular}{|c|c|}
\hline \multicolumn{2}{|c|}{$\begin{array}{l}\text { TRA-780, RCRA 90-Day Storage Area } \\
\text { (Radioactive Waste is Managed in the TRA-681, 682, 683, and 684 Storage Buildings) }\end{array}$} \\
\hline Chapter IV, LLW Requirements & Facility Compliance Information \\
\hline in the zone of water table fluctuation; and & \\
\hline $\begin{array}{l}3 \text { Located where radionuclide migration pathways are } \\
\text { predictable and erosion and surface runoff can be } \\
\text { controlled. }\end{array}$ & See M. above. \\
\hline $\begin{array}{l}\text { (b) Proposed sites with environmental characteristics, } \\
\text { geotechnical characteristics, and human activities for } \\
\text { which adequate protection cannot be provided through } \\
\text { facility design shall be deemed unsuitable for the } \\
\text { location of the facility. }\end{array}$ & See M. above. \\
\hline $\begin{array}{l}\text { (c) Low-level waste disposal facilities shall be sited to } \\
\text { achieve long-term stability and to minimize, to the extent } \\
\text { practical, the need for active maintenance following final } \\
\text { closure. }\end{array}$ & See M. above. \\
\hline $\begin{array}{l}\text { (2) Low-Level Waste Treatment and Storage Facility } \\
\text { Design. The following facility requirements and general } \\
\text { design criteria, at a minimum, apply: }\end{array}$ & See M. above. \\
\hline $\begin{array}{l}\text { (a) Confinement. Low-level waste systems and } \\
\text { components shall be designed to maintain waste } \\
\text { confinement. }\end{array}$ & See M. above. \\
\hline (b) Ventilation. & See M. above. \\
\hline $\begin{array}{l}1 \text { Design of low-level waste treatment and storage } \\
\text { facilities shall include ventilation, if applicable, through } \\
\text { an appropriate filtration system to maintain the release of } \\
\text { radioactive material in airborne effluents within the } \\
\text { requirements and guidelines specified in applicable } \\
\text { requirements. }\end{array}$ & See M. above. \\
\hline $\begin{array}{l}2 \text { When conditions exist for generating gases in } \\
\text { flammable or explosive concentrations, ventilation } \\
\text { systems or other measures shall be provided to keep the } \\
\text { gases in a non-flammable and nonexplosive condition. } \\
\text { Where concentrations of explosive or flammable gases } \\
\text { are expected to approach the lower flammability limit, } \\
\text { measures shall be taken to prevent deflagration or } \\
\text { detonation. }\end{array}$ & See M. above. \\
\hline $\begin{array}{l}\text { (c) Consideration of Decontamination and } \\
\text { Decommissioning. Areas in new and modifications to } \\
\text { existing low-level waste management facilities that are } \\
\text { subject to contamination with radioactive or other } \\
\text { hazardous materials shall be designed to facilitate } \\
\text { decontamination. For such facilities a proposed } \\
\text { decommissioning method or a conversion method } \\
\text { leading to reuse shall be described. }\end{array}$ & See M. above. \\
\hline
\end{tabular}


Table 10. (continued).

\begin{tabular}{|c|c|}
\hline \multicolumn{2}{|c|}{$\begin{array}{l}\text { TRA-780, RCRA 90-Day Storage Area } \\
\text { (Radioactive Waste is Managed in the TRA-681, 682, 683, and 684 Storage Buildings) }\end{array}$} \\
\hline Chapter IV, LLW Requirements & Facility Compliance Information \\
\hline $\begin{array}{l}\text { (d) Instrumentation and Control Systems. Engineering } \\
\text { controls shall be incorporated in the design and } \\
\text { engineering of low-level waste treatment and storage } \\
\text { facilities to provide volume inventory data and to prevent } \\
\text { spills, leaks, and overflows from tanks or confinement } \\
\text { systems. }\end{array}$ & See M. above. \\
\hline $\begin{array}{l}\text { (e) Monitoring. Monitoring and/or leak detection } \\
\text { capabilities shall be incorporated in the design and } \\
\text { engineering of low-level waste treatment and storage } \\
\text { facilities to provide rapid identification of failed } \\
\text { confinement and/or other abnormal conditions. }\end{array}$ & See M. above. \\
\hline $\begin{array}{l}\text { (3) Low-Level Waste Disposal Facility Design. The } \\
\text { following facility requirements and general design } \\
\text { criteria, at a minimum, apply: }\end{array}$ & See M. above. \\
\hline $\begin{array}{l}\text { (a) Confinement. Low-level waste systems and } \\
\text { components shall be designed to maintain waste } \\
\text { confinement. }\end{array}$ & See M. above. \\
\hline (b) Ventilation. & See M. above. \\
\hline $\begin{array}{l}\text { 1 Design of low-level waste disposal facilities shall } \\
\text { include ventilation, if applicable, through an appropriate } \\
\text { filtration system to maintain the release of radioactive } \\
\text { material in airborne effluents within the requirements } \\
\text { and guidelines specified in applicable requirements. }\end{array}$ & See M. above. \\
\hline $\begin{array}{l}2 \text { When conditions exist for generating gases in } \\
\text { flammable or explosive concentrations, ventilation } \\
\text { systems or other measures shall be provided to keep the } \\
\text { gases in a nonflammable and non-explosive condition. } \\
\text { Where concentrations of explosive or flammable gases } \\
\text { are expected to approach the lower flammability limit, } \\
\text { measures shall be taken to prevent deflagration or } \\
\text { detonation. }\end{array}$ & See M. above. \\
\hline $\begin{array}{l}\text { (c) Stability. Low-level waste disposal facilities shall be } \\
\text { designed to achieve long-term stability and to minimize } \\
\text { to the extent practical, the need for active maintenance } \\
\text { following final closure. }\end{array}$ & See M. above. \\
\hline $\begin{array}{l}\text { (d) Control of Water. Low-level waste disposal facilities } \\
\text { shall be designed to minimize to the extent practical, the } \\
\text { contact of waste with water during and after disposal. }\end{array}$ & See M. above. \\
\hline $\begin{array}{l}\text { N. Storage and Staging. The following requirements are } \\
\text { in addition to those in Chapter I of this Manual [DOE M } \\
435.1-1 \S \text { I.2.F(13)]. }\end{array}$ & $\begin{array}{l}\text { Not a facility-specific requirement. DOE Manual 435.1- } \\
1 \text { §I.2.F(13) applies to field element managers. }\end{array}$ \\
\hline $\begin{array}{l}\text { (1) Storage Prohibitions. Low-level waste in storage shall } \\
\text { not be readily capable of detonation, explosive } \\
\text { decomposition, reaction at anticipated pressures and }\end{array}$ & $\begin{array}{l}\text { IAG-451, Appendix A, addresses limitations on } \\
\text { chemicals that can be stored in the facility. } \\
\text { The NNSS waste acceptance criteria does not allow such }\end{array}$ \\
\hline
\end{tabular}


Table 10. (continued).

\begin{tabular}{|c|c|}
\hline \multicolumn{2}{|c|}{$\begin{array}{l}\text { TRA-780, RCRA 90-Day Storage Area } \\
\text { (Radioactive Waste is Managed in the TRA-681, 682, 683, and 684 Storage Buildings) }\end{array}$} \\
\hline Chapter IV, LLW Requirements & Facility Compliance Information \\
\hline $\begin{array}{l}\text { temperatures, or explosive reaction with water. Prior to } \\
\text { storage, pyrophoric materials shall be treated, prepared, } \\
\text { and packaged to be nonflammable. } \\
\text { From DOE G 435.1-1 Chapter IV: Compliance with this } \\
\text { requirement is demonstrated by having waste acceptance } \\
\text { requirements which prohibit low-level waste that is } \\
\text { ignitable or explosive from being accepted for storage } \\
\text { unless it has been treated, and procedures for properly } \\
\text { preparing such materials for safe storage. }\end{array}$ & $\begin{array}{l}\text { waste (MCP-17500); therefore, such waste would not be } \\
\text { stored at this facility. } \\
\text { Mixed waste that could be reactive may be stored at the } \\
\text { facility in accordance with RCRA requirements. }\end{array}$ \\
\hline $\begin{array}{l}\text { (2) Storage Limit. Low-level waste that has an identified } \\
\text { path to disposal shall not be stored longer than one year } \\
\text { prior to disposal, except for storage for decay, or as } \\
\text { otherwise authorized by the Field Element Manager. } \\
\text { From DOE G } 435.1-1 \text { Chapter IV: Storage longer than } \\
\text { one year can be justified if the conditions for such } \\
\text { storage are approved by the Field Element Manager as } \\
\text { part of the radioactive waste management basis for the } \\
\text { facility. }\end{array}$ & $\begin{array}{l}\text { MCP- } 17000 \$ 4.8 .16 \text { addresses storage time limits and } \\
\text { waste that is to be stored longer than } 1 \text { year. Appendix F, } \\
\text { "Container Start Date and Storage Prohibitions," } \\
\text { addresses storage time limits. }\end{array}$ \\
\hline $\begin{array}{l}\text { Storage for radioactive decay for a period greater than } 1 \\
\text { year for waste that has an identified path to disposal is } \\
\text { allowed. Adequate justification and the supporting } \\
\text { information for storage for decay is to be documented in } \\
\text { the radioactive waste management basis for the facility in } \\
\text { which the storage will take place. }\end{array}$ & \\
\hline $\begin{array}{l}\text { Mixed waste. Under the Federal Facility Compliance Act } \\
\text { of 1992, DOE sites were required to develop Site } \\
\text { Treatment Plans to bring stored mixed low-level waste } \\
\text { into compliance with these requirements. The Site } \\
\text { Treatment Plan needs to be consulted and any mixed } \\
\text { low-level waste stored for the purpose of accumulation to } \\
\text { facilitate treatment must meet Resource Conservation } \\
\text { and Recovery Act storage requirements. There could be } \\
\text { several ways within different scenarios that this } \\
\text { requirement can be met, as illustrated by the examples } \\
\text { below, however, there are basically four ways to show } \\
\text { compliance with the requirement and include appropriate } \\
\text { provisions in the radioactive waste management basis for } \\
\text { the facility in which it is stored. }\end{array}$ & \\
\hline $\begin{array}{l}\text { Legacy waste. As discussed above, the intention of the } \\
\text { requirement is not to force malicious compliance or } \\
\text { heroic actions which would result in increased risk or } \\
\text { safety concerns. Rather, the intention is that waste in } \\
\text { storage longer than one year receives additional attention } \\
\text { to ensure that the public, the workers, and the } \\
\text { environment are protected from the hazards of the waste, } \\
\text { and that progress is being made to dispose of the waste. } \\
\text { There could be several ways within different scenarios }\end{array}$ & \\
\hline
\end{tabular}


Table 10. (continued).

\begin{tabular}{|c|c|}
\hline \multicolumn{2}{|c|}{$\begin{array}{l}\text { TRA-780, RCRA 90-Day Storage Area } \\
\text { (Radioactive Waste is Managed in the TRA-681, 682, 683, and 684 Storage Buildings) }\end{array}$} \\
\hline Chapter IV, LLW Requirements & Facility Compliance Information \\
\hline $\begin{array}{l}\text { that this requirement can be met, as illustrated by the } \\
\text { examples below, however, there are basically four ways } \\
\text { to show compliance with the requirement: }\end{array}$ & \\
\hline $\begin{array}{l}\text { 1) the radioactive waste management basis allows for } \\
\text { storage for no more than one year. }\end{array}$ & \\
\hline $\begin{array}{l}\text { 2) the radioactive waste management basis allows for } \\
\text { storage for no more than one year, or for storage for } \\
\text { decay only for periods greater than a year, which are } \\
\text { specified on a radionuclide basis. }\end{array}$ & \\
\hline $\begin{array}{l}\text { 3) the radioactive waste management basis allows for } \\
\text { storage for more than one year, up to a specified period } \\
\text { of time based on a documented technical evaluation that } \\
\text { the waste can be stored in a manner that does not cause } \\
\text { changes to the waste or waste packages that is } \\
\text { detrimental to the safe storage of the waste, the final } \\
\text { disposal of the waste or to meeting the disposal } \\
\text { performance objectives. }\end{array}$ & \\
\hline $\begin{array}{l}\text { 4) the radioactive waste management basis allows for } \\
\text { storage for decay (with specifics) and for storage for } \\
\text { more than one year for other low-level waste, up to a } \\
\text { specified period of time based on a documented technical } \\
\text { evaluation that the waste can be stored in a manner that } \\
\text { does not cause changes to the waste or waste packages } \\
\text { that is detrimental to the safe storage of the waste, the } \\
\text { final disposal of the waste or to meeting the disposal } \\
\text { performance objectives. }\end{array}$ & \\
\hline $\begin{array}{l}\text { Compliance with this requirement is demonstrated by the } \\
\text { existence of a radioactive waste management basis for } \\
\text { the storage facility approved by the Field Element } \\
\text { Manager that includes the time frames that waste are } \\
\text { allowed to be stored, the necessary justifications for } \\
\text { storage for decay, and the necessary technical } \\
\text { evaluations if storage is to extend significantly beyond } \\
\text { the one-year time frame. }\end{array}$ & \\
\hline $\begin{array}{l}\text { (3) Storage Integrity. Low-level waste shall be stored in a } \\
\text { location and manner that protects the integrity of waste } \\
\text { for the expected time of storage and minimizes worker } \\
\text { exposure. }\end{array}$ & $\begin{array}{l}\text { LWP- } 15011 \S 5 \text { provides general radioactive storage area } \\
\text { requirements and } \$ 5.1 .7 \text { addresses outdoor storage of } \\
\text { radioactive material. }\end{array}$ \\
\hline $\begin{array}{l}\text { From DOE G } 435.1-1 \text { Chapter IV: However, in making a } \\
\text { decision to use a facility for storage and in developing a } \\
\text { radioactive waste management basis for the activity, } \\
\text { particular attention to protection of workers is needed. }\end{array}$ & \\
\hline $\begin{array}{l}\text { Compliance with this requirement is demonstrated if } \\
\text { sites have storage capabilities for low-level waste that } \\
\text { provide protection to waste containers so that their } \\
\text { integrity will not be damaged through physical or }\end{array}$ & \\
\hline
\end{tabular}


Table 10. (continued).

\begin{tabular}{|c|c|}
\hline \multicolumn{2}{|c|}{$\begin{array}{l}\text { TRA-780, RCRA 90-Day Storage Area } \\
\text { (Radioactive Waste is Managed in the TRA-681, 682, 683, and 684 Storage Buildings) }\end{array}$} \\
\hline Chapter IV, LLW Requirements & Facility Compliance Information \\
\hline $\begin{array}{l}\text { chemical (corrosion) processes and that keep personnel } \\
\text { from spending extended periods of time in the areas } \\
\text { where low-level waste is stored. }\end{array}$ & \\
\hline (4) Waste Characterization for Storage. & See below. \\
\hline $\begin{array}{l}\text { (a) Low-level waste that does not have an identified path } \\
\text { to disposal shall be characterized as necessary to meet } \\
\text { the data quality objectives and minimum characterization } \\
\text { requirements of this Chapter, to ensure safe storage, and } \\
\text { to facilitate disposal. }\end{array}$ & $\begin{array}{l}\text { This facility does not store LLW that does not have an } \\
\text { identified path to disposal. }\end{array}$ \\
\hline $\begin{array}{l}\text { (b) Characterization information for all low-level waste } \\
\text { in storage shall be maintained as a record in accordance } \\
\text { with the requirements for Records Management in } \\
\text { Chapter I of this Manual. }\end{array}$ & $\begin{array}{l}\text { SD-24.1.3 and MCP- } 17000 \S \S 4 \text { and } 5 \text { address the use of } \\
\text { IWTS and records. }\end{array}$ \\
\hline $\begin{array}{l}\text { From DOE G } 435.1-1 \text { Chapter IV: Compliance with this } \\
\text { requirement is demonstrated by documented procedures } \\
\text { for managing waste characterization and container } \\
\text { information on low-level waste as a Federal record. The } \\
\text { records are managed per the applicable policies and } \\
\text { procedures for records management referenced in DOE } \\
\text { O } 200.1 \text { and established at the applicable Field Element. }\end{array}$ & \\
\hline $\begin{array}{l}\text { (5) Container Inspection. A process shall be developed } \\
\text { and implemented for inspecting and maintaining } \\
\text { containers of low-level waste to ensure container } \\
\text { integrity is not compromised. }\end{array}$ & $\begin{array}{l}\text { LI- } 435 \text { requires quarterly inspections of radioactive } \\
\text { waste containers if waste is stored outdoors or has been } \\
\text { in storage for greater than } 1 \text { year. }\end{array}$ \\
\hline $\begin{array}{l}\text { From DOE G 435.1-1 Chapter IV: Compliance with this } \\
\text { requirement is demonstrated by: (1) a documented } \\
\text { process for waste container inspection and maintenance; } \\
\text { and ( } 2 \text { ) documentation for all waste container inspections } \\
\text { and maintenance actions performed. }\end{array}$ & \\
\hline $\begin{array}{l}\text { (6) Storage Management. Low-level waste storage shall } \\
\text { be managed to identify and segregate low-level waste } \\
\text { from mixed low-level waste. }\end{array}$ & $\begin{array}{l}\text { MCP- } 17000 \text { requires containers to have a unique IWTS } \\
\text { barcode that results in the segregation of the waste by } \\
\text { container. }\end{array}$ \\
\hline $\begin{array}{l}\text { (7) Staging. Staging of low-level waste shall be for the } \\
\text { purpose of the accumulation of such quantities of waste } \\
\text { as necessary to facilitate transportation, treatment, and } \\
\text { disposal. Staging longer than } 90 \text { days shall meet the } \\
\text { requirements for storage above and in Chapter I of this } \\
\text { Manual. }\end{array}$ & NA; waste is not staged at this facility. \\
\hline $\begin{array}{l}\text { From DOE G } 435.1-1 \text { Chapter IV: The staging of low- } \\
\text { level waste needs to be addressed in the radioactive } \\
\text { waste management basis for the facility that is } \\
\text { performing the staging. Generators, treatment facilities, } \\
\text { and disposal facilities that stage waste must ensure that } \\
\text { the action of staging is included and authorized as part of } \\
\text { their radioactive waste management basis for the affected } \\
\text { facilities, operations, or activities. }\end{array}$ & \\
\hline
\end{tabular}


Table 10. (continued).

\begin{tabular}{|c|c|}
\hline \multicolumn{2}{|c|}{$\begin{array}{l}\text { TRA-780, RCRA 90-Day Storage Area } \\
\text { (Radioactive Waste is Managed in the TRA-681, 682, 683, and 684 Storage Buildings) }\end{array}$} \\
\hline Chapter IV, LLW Requirements & Facility Compliance Information \\
\hline $\begin{array}{l}\text { Staging longer than } 90 \text { days must be justified, the } \\
\text { conditions for such storage met, and these practices } \\
\text { approved by the Field Element Manager as part of the } \\
\text { radioactive waste management basis for the facility. }\end{array}$ & \\
\hline $\begin{array}{l}\text { Compliance with this requirement is demonstrated by a } \\
\text { staging program that limits the temporary storage of } \\
\text { waste to only circumstances allowed in the requirement, } \\
\text { including justifications for any staging that exceeds the } \\
90 \text {-day period, which is documented in the radioactive } \\
\text { waste management basis for the facility. }\end{array}$ & \\
\hline $\begin{array}{l}\text { O. Treatment. Low-level waste treatment to provide } \\
\text { more stable waste forms and to improve the long-term } \\
\text { performance of a low-level waste disposal facility shall } \\
\text { be implemented as necessary to meet the performance } \\
\text { objectives of the disposal facility. }\end{array}$ & Treatment is not performed in this facility. \\
\hline $\begin{array}{l}\text { From DOE G 435.1-1 Chapter IV: Compliance with this } \\
\text { requirement is demonstrated when a treatment facility or } \\
\text { process ensures that treated waste will meet the } \\
\text { minimum waste form requirements of DOE M } 435.1 \text { and } \\
\text { meet additional disposal facility-specific waste } \\
\text { acceptance requirements for additional stability or long- } \\
\text { term performance of facilities that will receive the treated } \\
\text { waste. }\end{array}$ & \\
\hline $\begin{array}{l}\text { P. Disposal. Low-level waste disposal facilities shall } \\
\text { meet the following requirements. }\end{array}$ & LLW is not disposed of in this facility. \\
\hline $\begin{array}{l}\text { (1) Performance Objectives. Low-level waste disposal } \\
\text { facilities shall be sited, designed, operated, maintained, } \\
\text { and closed so that a reasonable expectation exists that the } \\
\text { following performance objectives will be met for waste } \\
\text { disposed of after September 26, 1988: }\end{array}$ & See P. above. \\
\hline $\begin{array}{l}\text { (a) Dose to representative members of the public shall } \\
\text { not exceed } 25 \text { mrem }(0.25 \mathrm{mSv}) \text { in a year total effective } \\
\text { dose equivalent from all exposure pathways, excluding } \\
\text { the dose from radon and its progeny in air. }\end{array}$ & See P. above. \\
\hline $\begin{array}{l}\text { (b) Dose to representative members of the public via the } \\
\text { air pathway shall not exceed } 10 \mathrm{mrem}(0.10 \mathrm{mSv}) \text { in a } \\
\text { year total effective dose equivalent, excluding the dose } \\
\text { from radon and its progeny. }\end{array}$ & See P. above. \\
\hline $\begin{array}{l}\text { (c) Release of radon shall be less than an average flux of } \\
20 \mathrm{pCi} / \mathrm{m}^{2} / \mathrm{s}\left(0.74 \mathrm{~Bq} / \mathrm{m}^{2} / \mathrm{s}\right) \text { at the surface of the disposal } \\
\text { facility. Alternatively, a limit of } 0.5 \mathrm{pCi} / 1(0.0185 \mathrm{~Bq} / \mathrm{l}) \\
\text { of air may be applied at the boundary of the facility. }\end{array}$ & See P. above. \\
\hline $\begin{array}{l}\text { (2) Performance Assessment. A site-specific radiological } \\
\text { performance assessment shall be prepared and } \\
\text { maintained for DOE low-level waste disposed of after }\end{array}$ & See P. above. \\
\hline
\end{tabular}


Table 10. (continued).

TRA-780, RCRA 90-Day Storage Area

(Radioactive Waste is Managed in the TRA-681, 682, 683, and 684 Storage Buildings)

\begin{tabular}{|c|c|}
\hline Chapter IV, LLW Requirements & Facility Compliance Information
\end{tabular}

September 26, 1988. The performance assessment shall include calculations for a 1,000 year period after closure of potential doses to representative future members of the public and potential releases from the facility to provide a reasonable expectation that the performance objectives identified in this Chapter are not exceeded as a result of operation and closure of the facility.

(a) Analyses performed to demonstrate compliance with See P. above. the performance objectives in this Chapter, and to establish limits on concentrations of radionuclides for disposal based on the performance measures for inadvertent intruders in this Chapter shall be based on reasonable activities in the critical group of exposed individuals. Unless otherwise specified, the assumption of average living habits and exposure conditions in representative critical groups of individuals projected to receive the highest doses is appropriate. The likelihood of inadvertent intruder scenarios may be considered in interpreting the results of the analyses and establishing radionuclide concentrations, if adequate justification is provided.

(b) The point of compliance shall correspond to the point See P. above. of highest projected dose or concentration beyond a 100 meter buffer zone surrounding the disposed waste. A larger or smaller buffer zone may be used if adequate justification is provided.

(c) Performance assessments shall address reasonably foreseeable natural processes that might disrupt barriers against release and transport of radioactive materials.

(d) Performance assessments shall use DOE-approved dose coefficients (dose conversion factors) for internal and external exposure of reference adults.

(e) The performance assessment shall include a sensitivity/uncertainty analysis.

(f) Performance assessments shall include a demonstration that projected releases of radionuclides to the environment shall be maintained as low as reasonably achievable (ALARA).

(g) For purposes of establishing limits on radionuclides that may be disposed of near-surface, the performance assessment shall include an assessment of impacts to water resources.

(h) For purposes of establishing limits on the concentration of radionuclides that may be disposed of near-surface, the performance assessment shall include an assessment of impacts calculated for a hypothetical

See P. above.

See P. above.

See P. above.

See P. above.

See P. above.

See P. above. 
Table 10. (continued).

\begin{tabular}{|c|c|}
\hline \multicolumn{2}{|c|}{$\begin{array}{l}\text { TRA-780, RCRA 90-Day Storage Area } \\
\text { (Radioactive Waste is Managed in the TRA-681, 682, 683, and } 684 \text { Storage Buildings) }\end{array}$} \\
\hline Chapter IV, LLW Requirements & Facility Compliance Information \\
\hline $\begin{array}{l}\text { person assumed to inadvertently intrude for a temporary } \\
\text { period into the low-level waste disposal facility. For } \\
\text { intruder analyses, institutional controls shall be assumed } \\
\text { to be effective in deterring intrusion for at least } 100 \text { years } \\
\text { following closure. The intruder analyses shall use } \\
\text { performance measures for chronic and acute exposure } \\
\text { scenarios, respectively, of } 100 \text { mrem }(1 \mathrm{mSv}) \text { in a year } \\
\text { and } 500 \text { mrem }(5 \mathrm{mSv}) \text { total effective dose equivalent } \\
\text { excluding radon in air. }\end{array}$ & \\
\hline $\begin{array}{l}\text { (3) Composite Analysis. For disposal facilities which } \\
\text { received waste after September 26, 1988, a site-specific } \\
\text { radiological composite analysis shall be prepared and } \\
\text { maintained that accounts for all sources of radioactive } \\
\text { material that may be left at the DOE site and may } \\
\text { interact with the low- level waste disposal facility, } \\
\text { contributing to the dose projected to a hypothetical } \\
\text { member of the public from the existing or future disposal } \\
\text { facilities. Performance measures shall be consistent with } \\
\text { DOE requirements for protection of the public and } \\
\text { environment and evaluated for a } 1,000 \text { year period } \\
\text { following disposal facility closure. The composite } \\
\text { analysis results shall be used for planning, radiation } \\
\text { protection activities, and future use commitments to } \\
\text { minimize the likelihood that current low- level waste } \\
\text { disposal activities will result in the need for future } \\
\text { corrective or remedial actions to adequately protect the } \\
\text { public and the environment. }\end{array}$ & $\begin{array}{l}\text { See P. above. } \\
\text { P. }\end{array}$ \\
\hline $\begin{array}{l}\text { (4) Performance Assessment and Composite Analysis } \\
\text { Maintenance. The performance assessment and } \\
\text { composite analysis shall be maintained to evaluate } \\
\text { changes that could affect the performance, design, and } \\
\text { operating bases for the facility. Performance assessment } \\
\text { and composite analysis maintenance shall include the } \\
\text { conduct of research, field studies, and monitoring needed } \\
\text { to address uncertainties or gaps in existing data. The } \\
\text { performance assessment shall be updated to support the } \\
\text { final facility closure. Additional iterations of the } \\
\text { performance assessment and composite analysis shall be } \\
\text { conducted as necessary during the post-closure period. }\end{array}$ & See P. above. \\
\hline $\begin{array}{l}\text { (a) Performance assessments and composite analyses } \\
\text { shall be reviewed and revised when changes in waste } \\
\text { forms or containers, radionuclide inventories, facility } \\
\text { design and operations, closure concepts, or the improved } \\
\text { understanding of the performance of the waste disposal } \\
\text { facility in combination with the features of the site on } \\
\text { which it is located alter the conclusions or the conceptual } \\
\text { model(s) of the existing performance assessment or } \\
\text { composite analysis. }\end{array}$ & See P. above. \\
\hline
\end{tabular}


Table 10. (continued).

\begin{tabular}{|c|c|}
\hline \multicolumn{2}{|c|}{$\begin{array}{l}\text { TRA-780, RCRA 90-Day Storage Area } \\
\text { (Radioactive Waste is Managed in the TRA-681, 682, 683, and 684 Storage Buildings) }\end{array}$} \\
\hline Chapter IV, LLW Requirements & Facility Compliance Information \\
\hline $\begin{array}{l}\text { (b) A determination of the continued adequacy of the } \\
\text { performance assessment and composite analysis shall be } \\
\text { made on an annual basis, and shall consider the results of } \\
\text { data collection and analysis from research, field studies, } \\
\text { and monitoring. }\end{array}$ & See P. above. \\
\hline $\begin{array}{l}\text { (c) Annual summaries of low-level waste disposal } \\
\text { operations shall be prepared with respect to the } \\
\text { conclusions and recommendations of the performance } \\
\text { assessment and composite analysis and a determination } \\
\text { of the need to revise the performance assessment or } \\
\text { composite analysis. }\end{array}$ & See P. above. \\
\hline $\begin{array}{l}\text { (5) Disposal Authorization. A disposal authorization } \\
\text { statement shall be obtained prior to construction of a new } \\
\text { low-level waste disposal facility. Field Elements with } \\
\text { existing low-level waste disposal facilities shall obtain a } \\
\text { disposal authorization statement in accordance with the } \\
\text { schedule in the Complex-Wide Low-Level Waste } \\
\text { Management Program Plan. The disposal authorization } \\
\text { statement shall be issued based on a review of the } \\
\text { facility's performance assessment, composite analysis, } \\
\text { performance assessment and composite analysis } \\
\text { maintenance, preliminary closure plan, and preliminary } \\
\text { monitoring plan. The disposal authorization statement } \\
\text { shall specify the limits and conditions on construction, } \\
\text { design, operations, and closure of the low-level waste } \\
\text { facility based on these reviews. A disposal authorization } \\
\text { statement is a part of the radioactive waste management } \\
\text { basis for a disposal facility. Failure to obtain a disposal } \\
\text { authorization statement by the implementation date of } \\
\text { this Order shall result in shutdown of the disposal } \\
\text { facility. }\end{array}$ & $\begin{array}{l}\text { See P. above. } \\
\end{array}$ \\
\hline $\begin{array}{l}\text { (6) Disposal Facility Operations. The disposal facility } \\
\text { design and operation must be consistent with the disposal } \\
\text { facility closure plan and lead to disposal facility closure } \\
\text { that provides a reasonable expectation that performance } \\
\text { objectives will be met. Low-level waste shall be disposed } \\
\text { in such a manner that achieves the performance } \\
\text { objectives stated in this Chapter, consistent with the } \\
\text { disposal facility radiological performance assessment. } \\
\text { Additional requirements include: }\end{array}$ & See P. above. \\
\hline $\begin{array}{l}\text { (a) Operating procedures shall be developed and } \\
\text { implemented for low-level waste disposal facilities that } \\
\text { protect the public, workers, and the environment; ensure } \\
\text { the security of the facility; minimize subsidence during } \\
\text { and after waste emplacement; achieve long-term stability } \\
\text { and minimize the need for long-term active maintenance; } \\
\text { and meet the requirements of the closure/post-closure } \\
\text { plan. }\end{array}$ & See P. above. \\
\hline
\end{tabular}


Table 10. (continued).

\begin{tabular}{|c|c|}
\hline \multicolumn{2}{|c|}{$\begin{array}{l}\text { TRA-780, RCRA 90-Day Storage Area } \\
\text { (Radioactive Waste is Managed in the TRA-681, 682, 683, and 684 Storage Buildings) }\end{array}$} \\
\hline Chapter IV, LLW Requirements & Facility Compliance Information \\
\hline $\begin{array}{l}\text { (b) Permanent identification markers for disposal } \\
\text { excavations and monitoring wells shall be emplaced. }\end{array}$ & See P. above. \\
\hline $\begin{array}{l}\text { (c) Low-level waste placement into disposal units shall } \\
\text { minimize voids between waste containers. Voids within } \\
\text { disposal units shall be filled to the extent practical. } \\
\text { Uncontainerized bulk waste shall also be placed in a } \\
\text { manner that minimizes voids and subsidence. }\end{array}$ & See P. above. \\
\hline $\begin{array}{l}\text { (d) Operations are to be conducted so that active waste } \\
\text { disposal operations will not have an adverse effect on } \\
\text { any other disposal units. }\end{array}$ & See P. above. \\
\hline $\begin{array}{l}\text { (e) Operations shall include a process for tracking and } \\
\text { documenting low-level waste placement in the facility by } \\
\text { generator source. }\end{array}$ & See P. above. \\
\hline $\begin{array}{l}\text { (7) Alternate Requirements for Low-Level Waste } \\
\text { Disposal Facility Design and Operation. Requirements } \\
\text { other than those set forth in this Section for the design } \\
\text { and operation of a low-level waste disposal facility may } \\
\text { be approved on a specific basis if a reasonable } \\
\text { expectation is demonstrated that the disposal } \\
\text { performance objectives will be met. }\end{array}$ & See P. above. \\
\hline $\begin{array}{l}\text { Q. Closure. The following requirements are in addition to } \\
\text { those in Chapter I of this Manual. }\end{array}$ & LLW is not disposed of in this facility. \\
\hline $\begin{array}{l}\text { (1) Disposal Facility Closure Plans. A preliminary } \\
\text { closure plan shall be developed and submitted to } \\
\text { Headquarters for review with the performance } \\
\text { assessment and composite analysis. The closure plan } \\
\text { shall be updated following issuance of the disposal } \\
\text { authorization statement to incorporate conditions } \\
\text { specified in the disposal authorization statement. Closure } \\
\text { plans shall: }\end{array}$ & See Q. above. \\
\hline $\begin{array}{l}\text { (a) Be updated as required during the operational life of } \\
\text { the facility. }\end{array}$ & See Q. above. \\
\hline $\begin{array}{l}\text { (b) Include a description of how the disposal facility will } \\
\text { be closed to achieve long-term stability and minimize the } \\
\text { need for active maintenance following closure and to } \\
\text { ensure compliance with the requirements of DOE } \\
5400.5, \text { Radiation Protection of the Public and the } \\
\text { Environment. }\end{array}$ & See Q. above. \\
\hline $\begin{array}{l}\text { (c) Include the total expected inventory of wastes to be } \\
\text { disposed of at the facility over the operational life of the } \\
\text { facility. }\end{array}$ & See Q. above. \\
\hline $\begin{array}{l}\text { (2) Disposal Facility Closure. Closure of a disposal } \\
\text { facility shall occur within a five-year period after it is } \\
\text { filled to capacity, or after the facility is otherwise } \\
\text { determined to be no longer needed. }\end{array}$ & See Q. above. \\
\hline
\end{tabular}


Table 10. (continued).

\begin{tabular}{|c|c|}
\hline \multicolumn{2}{|c|}{$\begin{array}{l}\text { TRA-780, RCRA 90-Day Storage Area } \\
\text { (Radioactive Waste is Managed in the TRA-681, 682, 683, and 684 Storage Buildings) }\end{array}$} \\
\hline Chapter IV, LLW Requirements & Facility Compliance Information \\
\hline $\begin{array}{l}\text { (a) Prior to facility closure, the final inventory of the } \\
\text { low-level waste disposed in the facility shall be prepared } \\
\text { and incorporated in the performance assessment and } \\
\text { composite analysis which shall be updated to support the } \\
\text { closure of the facility. }\end{array}$ & See Q. above. \\
\hline $\begin{array}{l}\text { (b) A final closure plan shall be prepared based on the } \\
\text { final inventory of waste disposed in the facility, the plan } \\
\text { implemented, and the updated performance assessment } \\
\text { and composite analysis prepared in support of the facility } \\
\text { closure. }\end{array}$ & See Q. above. \\
\hline $\begin{array}{l}\text { (c) Institutional control measures shall be integrated into } \\
\text { land use and stewardship plans and programs, and shall } \\
\text { continue until the facility can be released pursuant to } \\
\text { DOE 5400.5, Radiation Protection of the Public and the } \\
\text { Environment. }\end{array}$ & See Q. above. \\
\hline $\begin{array}{l}\text { (d) The location and use of the facility shall be filed with } \\
\text { the local authorities responsible for land use and zoning. }\end{array}$ & See Q. above. \\
\hline $\begin{array}{l}\text { R. Monitoring. The following requirements are in } \\
\text { addition to those in Chapter I of this Manual [DOE M } \\
435.1-1 \S \text { I.1.E(7)]. }\end{array}$ & See (1), (2), and (3) below. \\
\hline $\begin{array}{l}\text { (1) All Waste Facilities. Parameters that shall be sampled } \\
\text { or monitored, at a minimum, include: temperature, } \\
\text { pressure (for closed systems), radioactivity in ventilation } \\
\text { exhaust and liquid effluent streams, and flammable or } \\
\text { explosive mixtures of gases. Facility monitoring } \\
\text { programs shall include verification that passive and } \\
\text { active control systems have not failed. }\end{array}$ & $\begin{array}{l}\text { Monitoring requirements at INL radioactive waste } \\
\text { management facilities are tailored for the specific } \\
\text { facility to enable timely indication of developing } \\
\text { problems. Existing radiological control procedures and } \\
\text { assessments are followed/completed to monitor waste } \\
\text { facilities. } \\
\text { LRD-15001 and MCP-139 specify methods and }\end{array}$ \\
\hline $\begin{array}{l}\text { From DOE G 435.1-1 Chapter IV: The minimum } \\
\text { parameters specified in the requirement were selected } \\
\text { based on their potential significance for anticipating and } \\
\text { identifying undesirable conditions at low-level waste } \\
\text { management facilities. Each facility's radioactive waste } \\
\text { management basis should include an evaluation of the } \\
\text { applicability and significance of the minimum } \\
\text { parameters. This evaluation also needs to consider } \\
\text { additional parameters to be sampled or monitored to } \\
\text { ensure the protection of the public health, the } \\
\text { environment, and the workers. If a minimum parameter } \\
\text { specified in the requirement is deemed to be not } \\
\text { applicable in any way to the active operation of that } \\
\text { facility, then that justification should be included in the } \\
\text { radioactive waste management basis and when approved } \\
\text { constitutes an exemption to the manual. }\end{array}$ & $\begin{array}{l}\text { frequency of radiological control surveys of all } \\
\text { radiological areas. MCP-139 specifies the use of } \\
\text { Form } 441 . \text { A34. This form is referred to as the "routine } \\
\text { sheet" and is to be used by facility radiological control } \\
\text { foremen to list radiological areas that are to be surveyed, } \\
\text { the survey periods, and methods. }\end{array}$ \\
\hline $\begin{array}{l}\text { Verification activities are part of the radioactive waste } \\
\text { management basis as a condition for operation and } \\
\text { documented appropriately. }\end{array}$ & \\
\hline
\end{tabular}


Table 10. (continued).

\begin{tabular}{|c|c|}
\hline \multicolumn{2}{|c|}{$\begin{array}{l}\text { TRA-780, RCRA 90-Day Storage Area } \\
\text { (Radioactive Waste is Managed in the TRA-681, 682, 683, and 684 Storage Buildings) }\end{array}$} \\
\hline Chapter IV, LLW Requirements & Facility Compliance Information \\
\hline $\begin{array}{l}\text { Compliance with this requirement is demonstrated if } \\
\text { monitoring or sampling for the stated parameters is } \\
\text { performed for all facilities with a precision, accuracy, } \\
\text { and frequency consistent with timely identification of } \\
\text { developing problems and a justification exists in the } \\
\text { approved radioactive waste management basis for those } \\
\text { specified parameters which are not monitored or } \\
\text { sampled. }\end{array}$ & \\
\hline $\begin{array}{l}\text { (2) Liquid Waste Storage Facilities. For facilities storing } \\
\text { liquid low-level waste, the following shall also be } \\
\text { monitored: liquid level and/or waste volume, and } \\
\text { significant waste chemistry parameters. }\end{array}$ & NA; liquid waste is not stored at this facility in tanks. \\
\hline $\begin{array}{l}\text { From DOE G } 435.1-1 \text { Chapter IV: The objective of this } \\
\text { requirement is to mandate regular observation of } \\
\text { parameters that indicate the quantity of liquid low-level } \\
\text { waste stored in tanks. }\end{array}$ & \\
\hline $\begin{array}{l}\text { (3) Disposal Facilities. A preliminary monitoring plan for } \\
\text { a low-level waste disposal facility shall be prepared and } \\
\text { submitted to Headquarters for review with the } \\
\text { performance assessment and composite analysis. The } \\
\text { monitoring plan shall be updated within one year } \\
\text { following issuance of the disposal authorization } \\
\text { statement to incorporate and implement conditions } \\
\text { specified in the disposal authorization statement. }\end{array}$ & NA; LLW is not disposed of in this facility. \\
\hline $\begin{array}{l}\text { (a) The site-specific performance assessment and } \\
\text { composite analysis shall be used to determine the media, } \\
\text { locations, radionuclides, and other substances to be } \\
\text { monitored. }\end{array}$ & See (3) above. \\
\hline $\begin{array}{l}\text { (b) The environmental monitoring program shall be } \\
\text { designed to include measuring and evaluating releases, } \\
\text { migration of radionuclides, disposal unit subsidence, and } \\
\text { changes in disposal facility and disposal site parameters } \\
\text { which may affect long-term performance. }\end{array}$ & See (3) above. \\
\hline $\begin{array}{l}\text { (c) The environmental monitoring programs shall be } \\
\text { capable of detecting changing trends in performance to } \\
\text { allow application of any necessary corrective action prior } \\
\text { to exceeding the performance objectives in this Chapter. }\end{array}$ & See (3) above. \\
\hline
\end{tabular}




\section{REFERENCES}

ACLP-10.10, "RTC Radioanalytical Sample Management," Idaho National Laboratory.

DOE Guide 435.1-1, "Implementation Guide for Use with DOE M 435.1-1," U.S. Department of Energy, July 1999.

DOE Manual 435.1-1, "Radioactive Waste Management Manual,” U.S. Department of Energy, July 1999.

DOE Order 435.1, “Radioactive Waste Management,” U.S. Department of Energy, July 1999.

ECAR-484, "Hazard Categorization Document for the New Radiation Measurement Laboratory (TRA678 ) at the ATR Complex," Idaho National Laboratory.

EDF-4037, “TRA-666 and TRA-666A STAR Facility, Radiological Control Program Requirements,” Idaho National Laboratory.

Form 435.A01, "Radioactive Waste Container Inspection Checklist," Idaho National Laboratory.

Form 435.39, "Waste Determination and Disposition Form (WDDF)," Idaho National Laboratory.

Form 435.42, "Radioactive Waste Inventory Sheet," Idaho National Laboratory.

Form 441.A34, "INL Radiological Control Required Surveys," Idaho National Laboratory.

Form 450.02, "Waste Management Unit Registration Form," Idaho National Laboratory.

Form 450.33, “Temporary Accumulation Area Registration Form,” Idaho National Laboratory.

HAD-179, "Safety and Tritium Applied Research Facility,” Idaho National Laboratory.

HAD-277, "Reactor Technology Complex Radioactive Materials Storage Areas (TRA-617 and the Fenced Area East of TRA-605)," Idaho National Laboratory.

HAD-310, "Reactor Technology Complex TRA-780 RCRA 90-Day Storage Area," Idaho National Laboratory.

IAG-50, "INL Authorization Agreement for the Advanced Test Reactor (ATR) Complex Nuclear Materials Inspection and Storage (NMIS) Facility," Idaho National Laboratory.

IAG-443, "Tenant Use Agreement Between Facility Management Services, Laboratory Support Complex at the Advanced Test Reactor Complex and Waste Generator Services/Energy Solutions in Materials Storage Areas TRA-617 And Fenced Area East of TRA-605," Idaho National Laboratory.

IAG-451, "Tenant Use Agreement Between Facility Management Services, Laboratory Support Complex at the Advanced Test Reactor Complex and Waste Generator Services/Energy Solutions in Temporary Waste Management Area Buildings TRA-681, 682, 683, 684, 685, 686 and TRA-780," Idaho National Laboratory.

INL, 2010, Excess Legacy Materials Inventory Report for the Idaho National Laboratory, Idaho National Laboratory.

LI-435, “Waste Management Routine Field Activities,” Idaho National Laboratory.

LRD-15001, "Radiological Control Manual," Idaho National Laboratory.

LST-119, "INL Safety Basis List for the Nuclear Material Inspection And Storage (NMIS) Facility," Idaho National Laboratory.

LST-213, "NMIS Nuclear Safety Basis Implementation Matrix," Idaho National Laboratory.

LWP-8000, “Environmental Instructions for Facilities, Processes, Materials and Equipment," Idaho National Laboratory. 
LWP-13840, "Management of Issues, Observations, and Noteworthy Practices,” Idaho National Laboratory.

LWP-14002, “Timeout and Stop Work Authority,” Idaho National Laboratory.

LWP-15011, "Radioactive Material Areas and Radioactive Storage Areas," Idaho National Laboratory.

LWP-17000, "Waste Management," Idaho National Laboratory.

MCP-139, "Radiological Surveys,” Idaho National Laboratory.

MCP-17000, “Waste Generator Services Waste Management," Idaho National Laboratory.

MCP-17410, "Management of Waste Storage Areas," Idaho National Laboratory.

MCP-17500, "Waste Generator Services Certification of Waste Shipments to the Nevada Test Site," Idaho National Laboratory.

OMM-7.6.13.1.12, “Warm Waste Treatment System Operation,” Idaho National Laboratory.

OMM-7.11.13.1.3, "Evaporation Pond Sampling and Monitoring," Idaho National Laboratory.

OMM-7.11.13.8.1, “TRA-605 Warm Waste Treatment Facility Operation,” Idaho National Laboratory.

OMM-7.11.13.8.2, "Sampling Warm Waste Treatment system Effluent," Idaho National Laboratory.

OMM-7.11.13.8.4, “TRA-605 Effluent Radiation Monitor (ERM) Normal Operation,” Idaho National Laboratory.

OMM-7.11.13.8.9, “TRA-605 Effluent Radiation Monitor (ERM) System ATR Warm Waste Effluent Grab Sample," Idaho National Laboratory.

Permit No. 023-00001, "State of Idaho Permit to Construct an Air Pollution Emitting Source."

PDD-17000, “Waste Management Program,” Idaho National Laboratory.

PLN-114, “INL Emergency Plan/RCRA Contingency Plan,” Idaho National Laboratory.

PLN-114-5, "INL Emergency Plan/RCRA Contingency Plan Advanced Test Reactor Complex Appendix L6 TAA TRA-STR-780-1," Idaho National Laboratory.

PLN-522, "Quality Assurance Program Plan for the Waste Management/Waste Certification Program," Idaho National Laboratory.

PLN-3638, “Advanced Test Reactor Complex Radioactive Waste Management Basis,” Idaho National Laboratory.

SAR-153, "Upgraded Final Safety Analysis Report for the Advanced Test Reactor," Idaho National Laboratory.

SAR-154, "Safety Analysis Report for the Nuclear Materials Inspection And Storage (NMIS) Facility TRA-621," Idaho National Laboratory.

SD-24.1.3, “ATR Complex Facilities and Site Services Safety Basis Administrative Controls," Idaho National Laboratory.

SP-10.6.5.8, "RTC Non-Containerized Wastewater Management and Control," Idaho National Laboratory.

SP-10.6.5.10, "RTC Ponds Wastewater Acceptance Criteria,” Idaho National Laboratory. 